\title{
A global renewable energy scenario
}

\author{
Sørensen, Bent; Meibom, Peter
}

\section{Publication date:}

1998

\section{Document Version}

Publisher's PDF, also known as Version of record

\section{Citation for published version (APA):}

Sørensen, B., \& Meibom, P. (1998). A global renewable energy scenario. Roskilde Universitet. Tekster fra IMFUFA No. 354 http://milne.ruc.dk/ImfufaTekster/

\section{General rights}

Copyright and moral rights for the publications made accessible in the public portal are retained by the authors and/or other copyright owners and it is a condition of accessing publications that users recognise and abide by the legal requirements associated with these rights.

- Users may download and print one copy of any publication from the public portal for the purpose of private study or research. - You may not further distribute the material or use it for any profit-making activity or commercial gain.

- You may freely distribute the URL identifying the publication in the public portal.

\section{Take down policy}

If you believe that this document breaches copyright please contact rucforsk@kb.dk providing details, and we will remove access to the work immediately and investigate your claim. 


\section{TEKST NR 354}

\section{A GLOBAL \\ RENEWABLE ENERGY SCENARIO}

August 1998

\section{Bent Sørensen and Peter Meibom}

ROSKILDE UNIVERSITY, INSTITUTE 2, ENERGY \& ENVIRONMENT GROUP

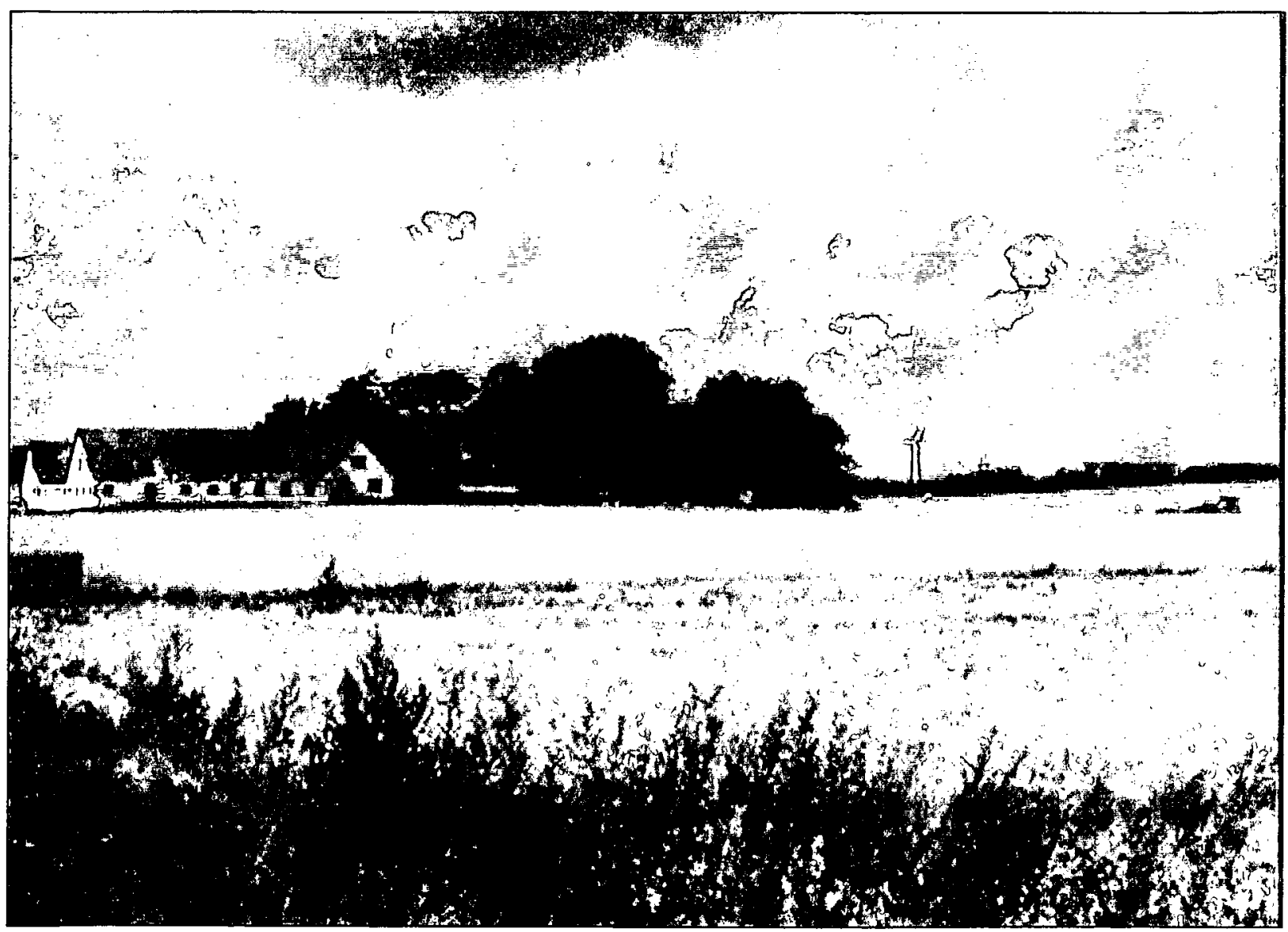

Project supported by the Danish Energy Agency

through "Energy \& society" contract EFP 1753/96-0002

Preprint of paper prepared for the

International Journal of Clobal Energy Issues

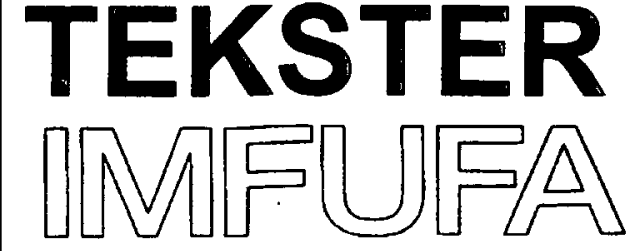

fra

ROSKILDE UNIVERSITETSCENTER

INSTITUT FOR STUDIET AF MATEMATIK OG FYSIK SAMT DERES

FUNKTIONER I UNDERVISNING, FORSKNING OG ANVENDELSER 
ROSKILDE UNIVERSITY, P O BOX 260, DK-4000 ROSKILDE, DENMARK

TEL: +4546742000 , FAX: +45 4674 3020, WEBSITE: http://mmf.ruc.dk/energy/

INSTITUTE OF STUDIES IN MATHEMATICS AND PHYSICS, AND THEIR FUNCTIONS

IN EDUCATION, RESEARCH AND APPLICATIONS

\title{
August 1998
}

A GLOBAL RENEWABLE ENERGY SCENARIO

Bent Sørensen and Peter Meibom

IMFUFA text 354, 112 sider

ISSN 01066242

\begin{abstract}
The scenario method is used to investigate, whether or not an energy supply system entirely based upon renewable energy sources (solar radiation, wind, biomass, environmental heat and hydro) can supply the energy globally required by the mid- $21^{\text {st }}$ century. A geographical information system (GIS) is employed to asses the spatial match between supply and demand, and the robustness of the scenario against changes in assumptions is discussed.
\end{abstract}

An energy demand scenario based on high economic growth and efficient use of energy is developed and matched with two supply scenarios: One uses only decentralised renewable energy resources, defined as building-integrated solar panels, a maximum of one wind turbine for each four farms, and biofuels derived entirely from agricultural and silvicultural waste. The other scenario adds solar cell parks on marginal land, wind turbines in clusters on-shore or offshore, and dedicated energy crops, all limited by the requirement of ecological sustainability and environmental acceptance.

It is found that the decentralised scenario works well in some regions but on a global average just barely matches the demand of the 2050 population with the assumed massively improved living standards. This implies that the scenario requires import of energy by countries such as India, and as surpluses exist mainly in South America and is dominantly in the form of electricity, the transfer will be difficult, and seemingly in contradiction with the "local self-sufficiency" idea behind the decentralised scenario.

By contrast, the centralised scenario has renewable energy supply in generous excess of demand, and trade of energy between regions will allow the system to be very robust against changes in assumptions such as demand development and area use. For example, desert regions in North Africa and the Middle East can export photovoltaic electric power to Europe and thereby create a basis for continued economic development without resort to oil.

The project is supported by a grant from the Danish Energy Agency, and it tries to answer the question, if the renewable energy plans formulated during recent decades for Denmark (including the official Energy 21 plan for the next 30 years) can become a model for global energy planning, or if they apply only to the particular situation in Denmark. The answer is that the solutions are highly transferable, and that in fact the Danish renewable resource situation is not better than the global average. Including, as the Danish Action Plan does, some offshore wind and other larger-scale options, the renewable energy system can satisfy an optimistic economic world development in a highly resilient way.

One of the authors (BS) has during his participation in the IPCC second assessment round (the result of which was published in 1996 with the title Global Change 1995) found an urgent need to develop better scenarios and worked-through examples of future energy demand and supply options. The present work is one such input into the further IPCC assessment work.

Key Figures are reproduced in colour towards the end of the paper. Front cover: renewable energy components (photo: B. Sørensen). Back cover: water colour by B. Sørensen after photo by M. Daugaard (appeared originally in the journal PRESS 1987). 


\title{
A GLOBAL RENEWABLE ENERGY SCENARIO
}

\author{
Bent Sørensen and Peter Meibom \\ Roskilde University, Institute 2, Energy \& Environment Group \\ Universitetsvej 1, P.O.Box 260, DK-4000 Roskilde, Denmark \\ Fax: +45 4674 3020, Email: bes@ruc.dk, web: http://mmf.ruc.dk/energy
}

\begin{abstract}
The scenario method is used to investigate, whether or not an energy supply system entirely based upon renewable energy sources (solar radiation, wind, biomass, environmental heat and hydro) can supply the energy globally required by the mid- $21^{\text {st }}$ century. A geographical information system (GIS) is employed to asses the spatial match between supply and demand, and the robustness of the scenario against changes in assumptions is discussed.
\end{abstract}

Keywords: Renewable energy, Energy systems, Global energy modelling, GIS.

\section{INTRODUCTION}

We build a scenario for global energy demand and supply by year 2050, based upon the following normative assumptions: Concern for human welfare and environmental sustainability leads to energy consumption patterns based on materials conservation and emphasis on nonmaterial ("information society") types of activity. Energy supply is designed to rely on renewable resources, used preferably in a decentralised mode. The energy system includes provisions for storage and transfer, in order to deal with the mismatch between the variability of important renewable energy sources such as solar radiation and wind, and variations in demand.

In the following, we first sketch the characteristics of the global 2050 society and derive the associated energy demands. Then we assess the potential contribution of each major renewable energy source, and finally the actual supply is fixed to match demand on a global level, leaving spatial variations to be dealt with by energy trade and transmission, and time variations to be dealt with by energy management and active storage cycles. The scenario year 2050 is selected sufficiently distant into the future to allow us to assume that the necessary changes in infrastructure and technology can be introduced in a smooth and gradual manner. The use of a geographical information system (GIS) allows us to express all quantities on an "energy flow per unit of land area" basis, a methodology which is particularly suited to describe the extraction and use of dispersed renewable energy flows. In a concluding section we deal with uncertainty of demand and economic factors that would determine or influence the implementation of the scenario considered.

\section{THE 2050 SOCIETY}

The energy scenario is based on a general vision of the characteristics of the global 2050 society, but one which is more a description of some general conditions assumed created than an attempt to forecast any actual picture of the precise technologies and activities prevailing at the time. The energy system is of course based on assumed developments of presently known technologies, but only as a means of proving the feasibility of the scenario: if better 
options emerge, as they almost certainly will, then they will be used, but our choice at least constitute a default to fall back on, and as such proves that there is a possible system of the kind envisaged, although not necessarily the optimum one.

\section{THE ENERGY DEMAND IN YEAR 2050}

The most recent revision of the United Nations population study estimates a year 2050 world population of $9.4 \times 10^{9}$, in its middle variant (UN, 1996). We assume that the middle variant will be most consistent with our assumption of significant advance in the economy of all regions of the world, and no devastating wars. Wars and hunger would diminish the estimate, whereas low degrees of development, coupled with ignorance and fundamentalism would lead to higher population numbers. The density distribution of the current world population is shown in Figure 1. It is a $0.5^{\circ} \times 0.5^{\circ}$ data set that we have extracted from the $19945^{\prime} \times 5^{\prime}$ data set of CIESIN (1997) described by Tobler et al. (1995). In order to project the population density to year 2050, we used both the UN estimated totals for each country and the projected development in the degree of urbanisation (UN, 1997). Regional urbanisation trends are shown in Table 1. We proceeded in the following way: The rural population density is changed according to the projected development, and at first, the population densities of existing cities are changed (almost invariably increased) according to the projections. However, if this makes the city population density higher than the largest existing today (taken as 5000 cap $/ \mathrm{km}^{2}$ on the $56 \mathrm{~km} \times 56 \mathrm{~km}$ grid used), the density is not allowed to grow any further. Instead, the extra population is distributed over neighbouring areas and this process is repeated until the density becomes lower than $5000 \mathrm{cap} / \mathrm{km}^{2}$. The result of this model procedure is a realistic growth of urban conglomerates. Figure 2 shows the resulting 2050 population density. Note that in some regions, the rural population decreases (as it has done earlier in currently industrialised areas), and that the concentration of populations in urban centres are often inconspicuous when illustrated on a world map.

Table 1. Summary of UN population and urbanisation projections (UN, 1996; 1997)

\begin{tabular}{|l|c|c|c|}
\hline Region & $\begin{array}{c}\text { Population 2050 } \\
\text { million }\end{array}$ & $\begin{array}{c}\text { Urban Pop. 2025 } \\
(\%)\end{array}$ & $\begin{array}{c}\text { Urban Pop. 2050 } \\
(\%)\end{array}$ \\
\hline Sub Saharan Africa & 1795 & 52 & 68 \\
\hline West Europe, Japan \& Pacific & 601 & 85 & 88 \\
\hline East Europe, former USSR \& Middle East & 1151 & 73 & 83 \\
\hline Latin America, India \& other SE Asia & 3737 & 58 & 71 \\
\hline North America & 387 & 85 & 90 \\
\hline China \& other centrally planned Asia & 1684 & 54 & 74 \\
\hline World & $\mathbf{9 3 5 5}$ & $\mathbf{6 1}$ & $\mathbf{7 4}$ \\
\hline
\end{tabular}

With respect to economic activity and energy demand, one expects the development to the mid-21st century to be dominated on one hand by efforts to "catch up" by currently poor countries, depending on several factors including issues of global equity in development and trade conditions. On the other hand, a determinant will be the nature of "new activities" being added to or replacing the current inventory of energy demanding undertakings. We have in recent decades seen information-related activities replace materials-related activities, and this development has (due to the often smaller energy requirements of information-related activities and products) lead to a de-coupling of economic growth and energy demand: Energy demands have risen much less than measures of economic activity such as gross national products. The expectation is that this trend will continue, and due to technical requirements the 
energy intensity of e.g. computer-related activities will continue to decrease, while the number of installations will increase.

Based on factors such as the ones outlined above, the energy demand by year 2050 has been estimated for different regions in the world, using the following methodology (Sørensen, 1996; see also Appendix in Kuemmel et al, 1997): Current energy supplied to the end-user (taken from statistics, such as OECD, 1996) is analysed with regard to the efficiency of the final conversion step, translating energy into a useful product or service. The net energy demand is taken as that used by the most efficient equipment available on the present market or definitely proven (e.g. available as a prototype). The assumption is thus that by 2050 , the average of all equipment used will have an energy efficiency equal to the best currently marketed or nearly marketed. We think that this is a fairly cautious assumption, as it neglects the certain invention of new methods and equipment working on principles different from those currently employed, and possibly improving efficiency by much more than marginal factors.

A summary of this type of analysis is given for the current energy system in Table 2, spelled out on energy use categories (reflecting different qualities of energy, from low-temperature heat to specific electric or mechanical energy for mobile use, and including human food intake as an energy input - a choice made because it is useful in analysing future energy use with a supply system using bio-energy for both food and energy purposes). Note that the above definition of end-use energy differs from what some statistical sources denote "enduse" or "final" energy.

Table 3 projects the net end-use energy per capita energy demands of Table 2 into a future situation, where all members of the future society (population about 10 billion) enjoy fulfilment of both basic and derived needs (including some that are not anticipated now and therefore have been included only as an overall growth percentage). Spelled out in terms of GNP per capita this involves more than a tripling of current end-use energy even in Western Europe (cf. Nielsen and Sørensen, 1998), Japan and the United States, and for the presently poor countries a lift to similar levels (only varying due to different needs for heating and cooling, due to different transportation needs depending on settlement densities, and due to the mix of industrial activities assumed for each region). The totals are based on the 2050 population estimates. Again the assumption is made that there be of no major wars or other oppression blocking the economic development and causing an uneven distribution of wealth between those benefiting from a "war economy" and those suffering destruction of their assets.

Table 4 shows one possible scenario (notably the one we are going to work with in our system analysis below) of the assumptions made to arrive at the actual end-use energy demand in year 2050, expressed in terms of the closeness of different societies to the "goal society" of Table 3. Factors included in this analysis include starting level of educational skills, presence of repressive rulers and fundamentalist institutions, as well as indications of the current rate of development. The ideal energy provisions of Table 3 would then be multiplied with the fraction of goal satisfaction derived from Table 4, reflecting the different weight given in the regional development processes to personal comfort, industrial manufacture and transportation. Food energy is consistently treated on the same footing as other energy forms, which is convenient in scenarios using biomass both for food production and for energy purposes.

The supply scenarios described below are all characterised by large fractions of the energy being delivered in the form of electricity, which allows some simplification, such as not distinguishing between stationary mechanical energy, necessary electric energy (i.e. where electricity is not performing tasks that could be performed as well by fuels) and high-temperature heat. It is also possible to assume that all low-temperature heat and refrigeration is provided by electrically driven heat pumps. For heat provision, this regains the thermodynamical effi- 
ciency factor that would be lost if electricity was used for direct resistance heating. Why the alternative of using solar thermal collectors for low-temperature heat is not explicitly treated is explained in the supply section below. In the transportation sector, there is a possibility to work with either electric energy or bio-fuels, and for providing food, an important choice is between vegetable and animal constituents of the food mix delivered to the end-users. We shall pursue these general problems a little further here in the section on demand, because they are of a generic nature and allow us to specify a quantity called delivered energy, i.e. the energy delivered to the end-user before his final conversion into goods or services. The delivered energy is essentially the "final energy" found in many statistical sources of historical data, and it is the quantity of interest from the energy supplier's point of view.

Table 2. Analysis of end-use energy 1994.

\begin{tabular}{|c|c|c|c|c|c|c|c|c|}
\hline $\begin{array}{l}\text { Region: } \\
1994 \text { analysis of } \\
\text { end-use energy }\end{array}$ & $\begin{array}{l}\text { 1. United } \\
\text { States, } \\
\text { Canada }\end{array}$ & $\begin{array}{l}\text { 2. W. } \\
\text { Europe, } \\
\text { Japan, } \\
\text { Australia }\end{array}$ & $\begin{array}{l}\text { 3. E. Eu- } \\
\text { rope, Ex- } \\
\text { Soviet, } \\
\text { Mid. East }\end{array}$ & $\begin{array}{l}\text { 4. Latin } \\
\text { America, } \\
\text { SE Asian } \\
\text { "tigers" }\end{array}$ & $\begin{array}{l}\text { 5. China, } \\
\text { India, rest } \\
\text { of Asia }\end{array}$ & 6. Africa & $\begin{array}{l}\text { A verage / } \\
\text { total }\end{array}$ & \\
\hline Space & 186 & 207 & 61 & 2 & 19 & 1 & 46 & W/cap \\
\hline Heating & 52 & 116 & 41 & 1 & 48 & 1 & 260 & GW \\
\hline Other low-T & 120 & 130 & 40 & 15 & 18 & 10 & 36 & W/cap \\
\hline heat & 34 & 73 & 27 & 12 & 47 & 7 & 199 & GW \\
\hline Medium-T & 40 & 50 & 30 & 10 & 10 & 5 & 17 & W/cap \\
\hline heat & 11 & 28 & 20 & 8 & 26 & 3 & 97 & GW \\
\hline High-T & 35 & 40 & 30 & 10 & 10 & 3 & 16 & W/cap \\
\hline heat & 10 & 22 & 20 & 8 & 26 & 2 & 88 & GW \\
\hline Space & 9 & 1 & 13 & 2 & 3 & 0 & 4 & W/cap \\
\hline cooling & 2 & 1 & 9 & 2 & 8 & 0 & 22 & GW \\
\hline Other re- & 29 & 23 & 14 & 2 & 2 & 0 & 7 & W/cap \\
\hline frigeration & 8 & 13 & 9 & 1 & 5 & 0 & 37 & $\mathrm{GW}$ \\
\hline Stationary & 100 & 130 & 80 & 25 & 5 & 4 & 34 & W/cap \\
\hline mechanical & 28 & 73 & 53 & 21 & 13 & 3 & 191 & GW \\
\hline Electric & 110 & 120 & 50 & 20 & 5 & 4 & 29 & W/cap \\
\hline appliances & 31 & 67 & 33 & 16 & 13 & 3 & 164 & GW \\
\hline Transpor- & 200 & 140 & 40 & 20 & 5 & 3 & 34 & W/cap \\
\hline tation & 56 & 79 & 27 & 16 & 13 & 2 & 193 & GW \\
\hline Food & 120 & 120 & 90 & 90 & 90 & 90 & 95 & W/cap \\
\hline energy & 34 & 67 & 60 & 74 & 233 & 61 & 530 & GW \\
\hline Total end-use & 948 & 962 & 448 & 195 & 167 & 121 & 318 & W/cap \\
\hline energy & 268 & 540 & 298 & 160 & 432 & 83 & 1781 & GW \\
\hline Population 1994 & 282 & 561 & 666 & 820 & 2594 & 682 & 5605 & million \\
\hline Region area & 20 & 15 & 28 & 26 & 20 & 31 & 141 & $\begin{array}{l}\text { million } \\
\mathrm{km}^{2}\end{array}$ \\
\hline
\end{tabular}

Regions are different from those employed in Table 1 and from those used in Sørensen (1996); see Appendix A for a list of countries included in each region. The assumption is that development patterns are similar in each of the regions constructed. Space heating and cooling are calculated on a geographical grid by the method described in section 3.1. The other entries depend on population density and the goal satisfaction fraction given in Table 4 for 1994. 
Table 3. Per capita end-use energy for "full goal satisfaction" and corresponding total end-use energy assuming the population estimates for year 2050 .

\begin{tabular}{|c|c|c|c|c|c|c|c|}
\hline $\begin{array}{l}\text { Regions: } \\
\text { / Energy } \\
\text { quality: }\end{array}$ & $\begin{array}{l}\text { 1. United } \\
\text { States, } \\
\text { Canada }\end{array}$ & $\begin{array}{l}2 . \text { W. Eu- } \\
\text { rope, Ja- } \\
\text { pan, Aus- } \\
\text { tralia }\end{array}$ & $\begin{array}{l}\text { 3. E. Eu- } \\
\text { rope, Ex- } \\
\text { Soviet, } \\
\text { Mid. East }\end{array}$ & $\begin{array}{l}\text { 4. Latin } \\
\text { America, } \\
\text { SE Asian } \\
\text { "tigers" }\end{array}$ & $\begin{array}{l}\text { 5. China, } \\
\text { India, rest } \\
\text { of Asia }\end{array}$ & 6. Africa & $\begin{array}{l}\text { Average } \\
\text { / Total }\end{array}$ \\
\hline $\begin{array}{l}\text { Space } \\
\text { heating* }\end{array}$ & 201 & 186 & 191 & 7 & 225 & 10 & \\
\hline $\begin{array}{l}\text { Other low- } \\
\text { temp. Heat }\end{array}$ & 150 & 150 & 150 & 150 & 150 & 150 & \\
\hline $\begin{array}{l}\text { Medium- } \\
\text { temp. Heat }\end{array}$ & 50 & 50 & 50 & 50 & 50 & 50 & \\
\hline $\begin{array}{l}\text { High-temp. } \\
\text { Heat }\end{array}$ & 40 & 40 & 40 & 40 & 40 & 40 & \\
\hline $\begin{array}{l}\text { Space } \\
\text { cooling* }\end{array}$ & 9 & 2 & 50 & 14 & 168 & 44 & \\
\hline $\begin{array}{l}\text { Other re- } \\
\text { frigeration }\end{array}$ & 35 & 35 & 35 & 35 & 35 & 35 & \\
\hline $\begin{array}{l}\text { Stationary } \\
\text { mechanical }\end{array}$ & 150 & 150 & 150 & 150 & 150 & 150 & \\
\hline $\begin{array}{l}\text { Electric } \\
\text { applicances }\end{array}$ & 150 & 150 & 150 & 150 & 150 & 150 & \\
\hline $\begin{array}{l}\text { Transpor- } \\
\text { tation }\end{array}$ & 200 & 150 & 200 & 150 & 150 & 150 & \\
\hline $\begin{array}{l}\text { Food en- } \\
\text { ergy }\end{array}$ & 120 & 120 & 120 & 120 & 120 & 120 & \\
\hline $\begin{array}{l}\text { Total } 2050 \\
\text { end-use e. }\end{array}$ & $\begin{array}{c}1105 \\
419\end{array}$ & $\begin{array}{c}1033 \\
545\end{array}$ & $\begin{array}{l}1136 \\
1181\end{array}$ & $\begin{array}{c}866 \\
1195\end{array}$ & $\begin{array}{l}1238 \\
4902\end{array}$ & $\begin{array}{l}899 \\
1834\end{array}$ & $\begin{array}{c}1079 \text { W/cap. } \\
10076 \mathrm{GW}\end{array}$ \\
\hline $\begin{array}{l}\text { Population } \\
2050\end{array}$ & 379 & 528 & 1040 & 1380 & 3960 & 2040 & $\begin{array}{c}9340 \\
\text { millions }\end{array}$ \\
\hline $\begin{array}{l}\text { Total area } \\
\text { million } \mathrm{km}^{2}\end{array}$ & 20.1 & 15.4 & 28.3 & 26.3 & 20.1 & 30.9 & 141.1 \\
\hline
\end{tabular}

* These rows are evaluated on the basis of temperature data in each GIS cell.

In the table, it is assumed that the distribution between regions of manufacturing industries and raw materials industries is proportional to the populations in each region. However, within each region there may be large differences. The same is true for variations in demand for space conditioning within regions induced by climate (for an assumed $60 \mathrm{~m}^{2}$ of heated or cooled space per capita), and in the case of transport by major differences between population densities within settled areas. Except for these more detailed investigations, the numbers are as in Sørensen (1996). Details of the estimation are given in appendix A of Kuemmel et al. (1997). 
Table 4. Fraction of "full goal satisfaction" assumed reached in 2050 scenario (estimated values for 1994 given for comparison, in parentheses).

\begin{tabular}{|l|c|c|c|c|c|c|}
\hline $\begin{array}{l}\text { Regions: } \\
\text { quality: }\end{array}$ & $\begin{array}{l}1 . \text { United } \\
\text { States, } \\
\text { Canada }\end{array}$ & $\begin{array}{l}\text { 2.W. Eu- } \\
\text { rope, Ja- } \\
\text { pan, Aus- } \\
\text { tralia }\end{array}$ & $\begin{array}{l}\text { 3. E. Eu- } \\
\text { rope, Ex- } \\
\text { Soviet, } \\
\text { Mid. East }\end{array}$ & $\begin{array}{l}\text { 4. Latin } \\
\text { America, } \\
\text { SE Asian } \\
\text { "tigers" }\end{array}$ & $\begin{array}{l}5 . \text { China, } \\
\text { rest of } \\
\text { Asia }\end{array}$ & 6. Africa \\
\hline Space heating & $\begin{array}{c}0.9 \\
(0.9)\end{array}$ & $\begin{array}{c}1.0 \\
(0.96)\end{array}$ & $\begin{array}{c}0.75 \\
(0.25)\end{array}$ & $\begin{array}{c}0.67 \\
(0.08)\end{array}$ & $\begin{array}{c}0.63 \\
(0.16)\end{array}$ & $\begin{array}{c}0.15 \\
(0.10)\end{array}$ \\
\hline $\begin{array}{l}\text { Other low- } \\
\text { temp. heat }\end{array}$ & $\begin{array}{c}0.87 \\
(0.8)\end{array}$ & $\begin{array}{c}1.0 \\
(0.87)\end{array}$ & $\begin{array}{c}0.53 \\
(0.27)\end{array}$ & $\begin{array}{c}0.6 \\
(0.10)\end{array}$ & $\begin{array}{c}0.67 \\
(0.12)\end{array}$ & $\begin{array}{c}0.13 \\
(0.07)\end{array}$ \\
\hline medium-temp. \\
heat & $\begin{array}{c}0.9 \\
(0.8)\end{array}$ & $\begin{array}{c}1.0 \\
(1.0)\end{array}$ & $\begin{array}{c}0.8 \\
(0.6)\end{array}$ & $\begin{array}{c}0.8 \\
(0.2)\end{array}$ & $\begin{array}{c}0.8 \\
(0.2)\end{array}$ & $\begin{array}{c}0.1 \\
(0.1)\end{array}$ \\
\hline $\begin{array}{l}\text { High-temp. } \\
\text { heat }\end{array}$ & $\begin{array}{c}0.88 \\
(0.88)\end{array}$ & $\begin{array}{c}1.0 \\
(1.0)\end{array}$ & $\begin{array}{c}0.75 \\
(0.75)\end{array}$ & $\begin{array}{c}0.75 \\
(0.25)\end{array}$ & $\begin{array}{c}0.75 \\
(0.25)\end{array}$ & $\begin{array}{c}0.13 \\
(0.08)\end{array}$ \\
\hline Refrigeration & $\begin{array}{c}1.0 \\
(0.83)\end{array}$ & $\begin{array}{c}1.0 \\
(0.67)\end{array}$ & $\begin{array}{c}0.4 \\
(0.4)\end{array}$ & $\begin{array}{c}0.5 \\
(0.05)\end{array}$ & $\begin{array}{c}0.33 \\
(0.05)\end{array}$ & $\begin{array}{c}0.05 \\
(0.01)\end{array}$ \\
\hline $\begin{array}{l}\text { Stationary } \\
\text { mechanical }\end{array}$ & $\begin{array}{c}0.93 \\
(0.67)\end{array}$ & $\begin{array}{c}1.0 \\
(0.87)\end{array}$ & $\begin{array}{c}0.53 \\
(0.53)\end{array}$ & $\begin{array}{c}0.67 \\
(0.17)\end{array}$ & $\begin{array}{c}0.67 \\
(0.03)\end{array}$ & $\begin{array}{c}0.13 \\
(0.03)\end{array}$ \\
\hline $\begin{array}{l}\text { Electric appli- } \\
\text { cances }\end{array}$ & $\begin{array}{c}1.0 \\
(0.73)\end{array}$ & $\begin{array}{c}1.0 \\
(0.8)\end{array}$ & $\begin{array}{c}0.53 \\
(0.33)\end{array}$ & $\begin{array}{c}0.67 \\
(0.13)\end{array}$ & $\begin{array}{c}0.67 \\
(0.03)\end{array}$ & $\begin{array}{c}0.1 \\
(0.03)\end{array}$ \\
\hline $\begin{array}{l}\text { Transpor- } \\
\text { tation }\end{array}$ & $\begin{array}{c}0.9 \\
(1.0)\end{array}$ & $\begin{array}{c}1.0 \\
(0.93)\end{array}$ & $\begin{array}{c}0.35 \\
(0.20)\end{array}$ & $\begin{array}{c}0.67 \\
(0.13)\end{array}$ & $\begin{array}{c}0.33 \\
(0.03)\end{array}$ & $\begin{array}{c}0.1 \\
(0.02)\end{array}$ \\
\hline Food energy & $\begin{array}{c}1.0 \\
(1.0)\end{array}$ & $\begin{array}{c}1.0 \\
(1.0)\end{array}$ & $\begin{array}{c}1.0 \\
(0.75)\end{array}$ & $\begin{array}{c}1.0 \\
(0.75)\end{array}$ & $\begin{array}{c}1.0 \\
(0.75)\end{array}$ & $\begin{array}{c}0.83 \\
(0.75)\end{array}$ \\
\hline $\begin{array}{l}\text { Averages of } \\
\text { the above }\end{array}$ & $\begin{array}{c}\mathbf{0 . 9 3} \\
(\mathbf{0 . 8 5})\end{array}$ & $\begin{array}{c}\mathbf{1 . 0} \\
\mathbf{( 0 . 9 0 )}\end{array}$ & $\begin{array}{c}\mathbf{0 . 6 2} \\
(\mathbf{0 . 4 5})\end{array}$ & $\begin{array}{c}\mathbf{0 . 6 8} \\
(\mathbf{0 . 2 1})\end{array}$ & $\begin{array}{c}\mathbf{0 . 6 4} \\
(\mathbf{0 . 1 8})\end{array}$ & $\begin{array}{c}\mathbf{0 . 2 0} \\
(\mathbf{0 . 1 3})\end{array}$ \\
\hline
\end{tabular}

In distributing industrial manufacture on regions, it is assumed that robot technology provides a "backstop" wall against excessively low-salaried regions, but in any case, most regions are assumed to reach a high level of wealth before year 2050 , implying that little low-salary advantage will be left by then. An exception is Africa, and at the same time a chance for this continent to catch up, if a viable manufacturing industry can be established. In the transition period 1990-2050, this role was regarded as assumed by regions 3-5.

Table 5. Current food delivery to end-users (Alexandratos, 1995)

\begin{tabular}{|lccc|}
\hline Food supplies 1990 & Total (W/cap.) & Animal food & Vegetable food \\
\hline US/Canada/W.Europe/Oceania & 166 & 53 & 47 \\
\hline Formerly Centrally Planned & 164 & 44 & 56 \\
\hline Latin America & 131 & 33 & 67 \\
\hline South Asia & 108 & 21 & 79 \\
\hline East Asia & 127 & 9 & 91 \\
\hline Middle East/N. Africa & 146 & 21 & 79 \\
\hline Sub-Sahara Africa & 102 & 10 & 90 \\
\hline World & $\mathbf{1 3 1}$ & $\mathbf{2 8}$ & $\mathbf{7 2}$ \\
\hline Developing countries & 120 & 16 & 84 \\
\hline Developed countries & 165 & 32 & 68 \\
\hline
\end{tabular}


Table 6. Energy delivered to end-user in 2050 scenario.

\begin{tabular}{|c|c|c|c|c|c|c|c|}
\hline $\begin{array}{l}\text { Regions: } \\
\text { / Energy } \\
\text { quality: }\end{array}$ & $\begin{array}{l}\text { 1. United } \\
\text { States, } \\
\text { Canada }\end{array}$ & $\begin{array}{l}\text { 2. W. Eu- } \\
\text { rope, Ja- } \\
\text { pan, Aus- } \\
\text { tralia }\end{array}$ & $\begin{array}{l}\text { 3. E. Eu- } \\
\text { rope, Ex- } \\
\text { Soviet, } \\
\text { Mid. East }\end{array}$ & $\begin{array}{l}\text { 4. Latin } \\
\text { America, } \\
\text { SE Asian } \\
\text { "tigers" }\end{array}$ & $\begin{array}{l}\text { 5. China, } \\
\text { rest of } \\
\text { Asia }\end{array}$ & 6. Africa & $\begin{array}{l}\text { Average } \\
\text { / Total }\end{array}$ \\
\hline $\begin{array}{l}\text { Food based } \\
\text { on animals }\end{array}$ & $\begin{array}{l}30 \\
45 \\
17\end{array}$ & $\begin{array}{l}30 \\
45 \\
24\end{array}$ & $\begin{array}{l}30 \\
45 \\
47\end{array}$ & $\begin{array}{l}25 \\
37 \\
52\end{array}$ & $\begin{array}{c}25 \\
37 \\
148\end{array}$ & $\begin{array}{l}20 \\
25 \\
51\end{array}$ & $\begin{array}{c}23 \% \\
36 \mathrm{~W} / \mathrm{cap} . \\
339 \mathrm{GW}\end{array}$ \\
\hline $\begin{array}{l}\text { Food based } \\
\text { on grain \& } \\
\text { vegetables }\end{array}$ & $\begin{array}{c}70 \\
119 \\
45\end{array}$ & $\begin{array}{c}70 \\
119 \\
63\end{array}$ & $\begin{array}{c}70 \\
119 \\
124\end{array}$ & $\begin{array}{c}75 \\
128 \\
177\end{array}$ & $\begin{array}{c}75 \\
128 \\
506\end{array}$ & $\begin{array}{c}80 \\
114 \\
232\end{array}$ & $\begin{array}{c}77 \% \\
123 \mathrm{~W} / \mathrm{cap} . \\
1148 \mathrm{GW}\end{array}$ \\
\hline $\begin{array}{l}\text { Gross } \\
\text { transporta- } \\
\text { tion energy }\end{array}$ & $\begin{array}{l}359 \\
136\end{array}$ & $\begin{array}{l}299 \\
158\end{array}$ & $\begin{array}{l}140 \\
146\end{array}$ & $\begin{array}{l}201 \\
277\end{array}$ & $\begin{array}{c}99 \\
392\end{array}$ & $\begin{array}{l}30 \\
61\end{array}$ & $\begin{array}{l}125 \mathrm{~W} / \mathrm{cap} . \\
1170 \mathrm{GW}\end{array}$ \\
\hline $\begin{array}{l}\text { Heat pump } \\
\text { input for } \\
\text { low-T heat } \\
\text { and cooling }\end{array}$ & $\begin{array}{c}103 \\
39\end{array}$ & $\begin{array}{c}110 \\
58\end{array}$ & $\begin{array}{l}87 \\
90\end{array}$ & $\begin{array}{l}43 \\
60\end{array}$ & $\begin{array}{c}80 \\
318\end{array}$ & $\begin{array}{l}22 \\
45\end{array}$ & $\begin{array}{l}65 \mathrm{~W} / \mathrm{cap} . \\
610 \mathrm{GW}\end{array}$ \\
\hline $\begin{array}{l}\text { Environ- } \\
\text { mental heat }\end{array}$ & $\begin{array}{c}240 \\
91\end{array}$ & $\begin{array}{l}256 \\
135\end{array}$ & $\begin{array}{l}203 \\
210\end{array}$ & $\begin{array}{l}100 \\
140\end{array}$ & $\begin{array}{l}186 \\
741\end{array}$ & $\begin{array}{c}51 \\
105\end{array}$ & $\begin{array}{l}151 \text { W/cap. } \\
1421 \mathrm{GW}\end{array}$ \\
\hline $\begin{array}{l}\text { Direct } \\
\text { electric and } \\
\text { all other } \\
\text { energy }\end{array}$ & $\begin{array}{l}420 \\
153\end{array}$ & $\begin{array}{l}424 \\
224\end{array}$ & $\begin{array}{l}245 \\
255\end{array}$ & $\begin{array}{l}288 \\
398\end{array}$ & $\begin{array}{c}283 \\
1116\end{array}$ & $\begin{array}{l}47 \\
96\end{array}$ & $\begin{array}{l}240 \text { W/cap. } \\
2242 \mathrm{GW}\end{array}$ \\
\hline $\begin{array}{l}\text { Total de- } \\
\text { livered } \\
\text { energy* }\end{array}$ & $\begin{array}{c}1272 \\
482\end{array}$ & $\begin{array}{c}1252 \\
661\end{array}$ & $\begin{array}{l}838 \\
871\end{array}$ & $\begin{array}{c}800 \\
1104\end{array}$ & $\begin{array}{c}814 \\
3225\end{array}$ & $\begin{array}{l}290 \\
591\end{array}$ & $\begin{array}{l}742 W / \text { cap. } \\
6934 \text { GW }\end{array}$ \\
\hline $\begin{array}{l}\text { Population } \\
2050\end{array}$ & 379 & 528 & 1040 & 1380 & 3960 & 2040 & $\begin{array}{c}9340 \\
\text { millions }\end{array}$ \\
\hline
\end{tabular}

* Including heat drawn from the environment by heat pumps.

\subsection{Space conditioning}

The average per capita energy consumption is taken as constant within each economic region, except for the space heating and cooling energy demand, which is related to the actual temperatures at a given location. Space heating is assumed to be required if the monthly average temperature is below $16^{\circ} \mathrm{C}$. This would give an indoor temperature above $20^{\circ} \mathrm{C}$ in a suitably constructed buildings, taking into account thermal mass (to smooth out day-to-night temperature differences) and indoor activities producing waste heat. Space cooling is considered necessary for monthly average temperatures above $24^{\circ} \mathrm{C}$, again with consideration of optimum use of building thermal mass and devices such as smart solar window screens. The rate of energy provision for heating and cooling is calculated from the temperature difference $\Delta \mathrm{T}$ by the simple formula $\mathrm{P}=\mathrm{C} \times \Delta \mathrm{T}$ (Sørensen, 1979), where $\mathrm{C}=36 \mathrm{~W} / \mathrm{cap} / \mathrm{deg}$. assuming an average heated or cooled space of $60 \mathrm{~m}^{2}$ per person (living and working spaces) (Kuemmel et al., 1997, Appendix A). Just under $60 \%$ of the space heating covers heat losses through external walls, the rest is air exchange, partially through heat exchangers. 
Figure 3 shows the measured seasonal temperatures (taken from Leemans and Cramer, 1998; the data are consistent with other sources such as NCEP/NCAR, 1998) and indicates the seasonal movements of the borders defining the onset of needs for space cooling or space heating. Figures 4 and 5 gives the energy per unit of populated land area required in 2050 for full satisfaction of heating and cooling needs, respectively. It is the quantity $|\mathrm{P}|$ defined above times the population density for 2050. Figure 6 gives the direct energy input to these processes in the actual 2050 scenario, along with that to other low temperature heat requirement (the row "other low-T heat" in Tables 4). The heat pump technologies assumed used in the scenario employs electricity as high-quality energy input and environmental heat (from air, soil or waterways) for the low-quality source. A fairly low average COP (coefficient of performance, i.e. ratio of heat output to electricity input) of three is assumed for the heat pumps, because many of them will be placed at high latitude locations (where the space heating need is largest). At these locations they will in most cases need soil sources and corresponding technology for the low-temperature source. Current technology uses pipes shot through the earth at frost-free depths by special machinery to extract this heat, and the rather low COP is an indication of the average current performance of such systems in cold climates. Table 6 gives both the heat pump electric energy inputs and the energy drawn from the environment.

\subsection{Food energy}

The food currently supplied to end-users is given on a regional basis in Table 5 . It is seen that the ratio of animal and vegetable foods vary considerably between regions. The biological energy requirement is on average $120 \mathrm{~W}$ for an adult (Sørensen, 1979), so the average delivered seems adequate, but deficits occur in South Asia and sub-Saharan Africa. There is also a loss between delivered and consumed food, but this loss is presumably smaller in regions of food shortage. For the "full goal satisfaction" scenario we shall assume a food supply with the regional distribution on foods of animal and vegetable origin shown in Table 6 , and including losses at the end-user of $20 \%$ for animal food and $30 \%$ for vegetable food (i.e. delivered energy times $0.8 / 0.7$ equals end-use food energy). The losses would typically be vegetable stalks, husk and peeling residues, plus meat fat, skin or bones. They may contribute to energy provision through collection of household refuse, e.g. for biogas production. The actual 2050 scenario food energy delivered is given in Table 6. It corresponds to full satisfaction of needs except in Africa, but the ratios of animal and vegetable food still vary between regions, although less that today. This assumes a move towards what is considered a more healthy diet in the currently most meat-intensive parts of the world. The geographical distribution of vegetable and animal food product deliveries used in the 2050 scenario is given in energy units in Figures 7 and 8.

\subsection{Energy for transportation}

Energy for the transportation sector is by 2050 either electricity (trains and urban electric vehicles) or fuels (bio-fuels such as methanol, or hydrogen). The net end-use energy for road transportation considered in Table 3 only accounts for basic friction losses and assumes acceleration and potential energy (when climbing uphill) expenditures as partially reclaimed during breaking and downhill driving, and similar assumptions are made for other types of transport. It is therefore assumed here that the energy delivered to the vehicle must be twice the end-use energy. For fuel-cell operation this accounts for typical conversion losses (fuel cell efficiencies of $50 \%$ are still considerably higher than the efficiencies around $20 \%$ characterising most current gasoline or diesel cars), and for electric vehicles, where the energy efficiency is well over $90 \%$, the $50 \%$ "loss" may be considered to represent storage cycle losses in battery charging processes and discharges during extended parking. The delivered 
energy for transportation given in Table 6 is simply twice that obtained by multiplying the value from Table 3 by the goal satisfaction factor of Table 4. Its geographical distribution is given in Figure 9.

\subsection{Electricity and other high-quality energy}

The remaining energy not accounted for in the above subsections is called "Electricity etc." in Table 6. It comprises medium and high temperature heat, refrigeration other than space cooling, stationary mechanical energy and dedicated electric energy. No distinction is made between delivered and end-use energy, as the electricity to heat losses are zero and the electric appliance energy inputs are anyway estimated as electricity delivered, in our sources (Sørensen, 1996; Kuemmel et al., 1997). The geographical distribution assumed in the 2050 scenario is shown in Figure 10.

\subsection{Summary of 2050 scenario energy demand.}

The total amounts of energy that have to be delivered to the end-users are shown in Table 6 , split on regions and given both as totals and per capita energy flows. The geographical distribution is shown in Figure 11. It is seen that the amount of energy on average is $0.9 \mathrm{~W} /$ cap or three times the amount furnished today (cf. Table 2). This proves that the 2050 scenario does indeed assume a considerable lift in the activities depending on energy supply. In judging the fairly low values it should be kept in mind, that the primary energy produced today (the global average of which is about $2 \mathrm{~W} / \mathrm{cap}$.) goes through a number of conversion processes before reaching the final consumer and being converted to end-use products or services. The central conversion processes have efficiencies of around 0.3 (fuel efficiency of average electric power plant plus transmission losses) to around 0.9 (fuel combustion in industry). A large part of the current losses from a primary average production of $2 \mathrm{~W} / \mathrm{cap}$. to an end-use energy of only $0.3 \mathrm{~W} / \mathrm{cap}$. is therefore associated with the final conversion taking place at the end user. This is consistent with our data indicating that end-use conversion efficiency is improved by a factor of $3-4$, when the current equipment is replaced with the best available. In the 2050 scenario, the currently most efficient equipment is assumed to be used, and the delivered energy of $0.9 \mathrm{~W} / \mathrm{cap}$. requires a primary production (discussed in chapters 4 and 5) not much higher. Thus the 2050 scenario finds it possible, as we shall show, to deliver three times more end-use energy than the present system, with a primary input that may not exceed that of the current system.

\section{RENEWABLE ENERGY SUPPLY OPTIONS}

The renewable energy sources and conversion technologies considered in the 2050 scenario are direct solar radiation used in flat-plate solar cells, wind energy converted by horizontalaxis turbines, hydro energy used in turbines power stations, and a range of bio-technologies, including food production from grain and other vegetable harvests and meats from animal raising, liquid biofuels such as methanol produced by thermal processes, or biogas produced by biological methods (Sørensen, 1979). For simplicity, some minor sources were left out (fish in the food sector, geothermal energy), although they would make a contribution in a more detailed and realistic scenario.

Solar thermal is an option that competes with photovoltaics for building roof and facade space. We have opted for the photovoltaic solution, even for covering low-temperature heating needs, because the efficiency of the solar-to-electricity-to-heat conversion route is high: Assuming $15 \%$ efficient solar cells and $\mathrm{COP}=3$ heat pumps the total efficiency is $35 \%$. Ther- 
mal solar collectors may have a direct efficiency of $50 \%$, but the heat produced has to be stored, e.g. in communal storage systems, in order to satisfy demand when there is no solar radiation. Because most of the heating demand is at high latitudes, this means seasonal storage, which cannot claim a turn-around efficiency of more than of the order of $25 \%$, if conventional heat-capacity storage is used. Thus the overall efficiency of the solar-to-heat-tostored heat-to-useful heat is some three times lower than for the photovoltaic route. On the other hand, the expected cost reductions assumed for photovoltaic systems may turn out not to materialise, in which case the solar thermal option might again seem attractive.

For biomass, the option of direct combustion has not been considered, due to its environmental impacts similar to those of the fossil fuels that would be replaced. However, in a transition period it there may still be direct fuel uses of biomass, particularly if short-term reduction in net greenhouse gas emissions are considered important. Below we discuss the scenario assumptions for each energy source and calculate the magnitude of the available ressource under realistic assumptions of exploitation, considering both environmental and social constraints. First the assumptions on land use are presented, as they enter in all the considerations on the potential for using individual renewable energy technologies. For off-shore wind power, also sea-depth topology is important, as it would be for certain fish or kelp cultures. The land topography and roughness data could be used in estimating wind conditions, but we chose to base the wind resource estimate on measured data.

\subsection{Topography and land use}

The topography map shown in Figure 12 is used in estimating suitable sites for off-shore wind turbines. It is based on a latitude-longitude grid of $0.83^{\circ} \times 0.83^{\circ}$, but is constructed from data on a much finer grid (Smith and Sandwell, 1997; Sandwell et al., 1998).

Table 7. Definition of area types relative to USGS classification

\begin{tabular}{|l|l|}
\hline Definition used & USGS classification \\
\hline Urban and built-up land & Urban and built-up land, however estimated with different algorithm \\
\hline $\begin{array}{l}\text { Cropland (including crop- } \\
\text { land/pasture in rotation) }\end{array}$ & $\begin{array}{l}\text { Rainfed and irrigated cropland and pasture plus } 50 \% \text { of cropland/grassland and } \\
\text { cropland/woodland mosaic }\end{array}$ \\
\hline Open cropland & Same as above except omitting cropland/woodland mosaic \\
\hline Rangeland & Grassland and $50 \%$ of cropland/grassland mosaic and mixed scrub/grassland \\
\hline Forest & Deciduous and evergreen broadleaf, needleleaf and mixed forests \\
\hline Marginal land & Barren or sparsely vegetated land, scrubland plus $50 \%$ of mixed scrub/grassland \\
\hline Water bodies & Water bodies \\
\hline Other land & Savanna, wetlands, tundras and land covered by snow or ice \\
\hline
\end{tabular}

Land-use data are important in the description of agricultural yields, whether based on cropland or grazing ranges, for forestry and possible energy crops, and for selecting land suited for placement of wind turbines and solar collector fields. The building-integrated photovoltaic systems require an estimate of suitable surfaces, which we make from data on urbanisation 
and dispersed farm densities. For our minimum grid size of $56 \mathrm{~km} \times 56 \mathrm{~km}$ (at the Equator), there will typically be more than one type of land use inside each grid cell. We therefore constructed a database giving fractions of each type of land use inside the grid structure we are using. There exist several land-cover databases in the literature. We use one based upon $1 \mathrm{~km}$ resolution radiometer data for the period April 1992 to March 1993 (US Geological Survey, 1997). The data are first converted from the Lambert Azimuthal Equal Area Projection to our latitude-longitude $0.5^{\circ} \times 0.5^{\circ}$ grid, using an algorithm developed by Evenden (1997). Then the land use data for all the $1 \mathrm{~km}$ cells that have centres inside one of our $56 \mathrm{~km}$ cells are recounted. Of the several classifications offered by USGS we use their indigenous 24 category classification (Anderson et al., 1976). This we again simplify as shown in Table 7, in a way offering the categories needed for the energy model.

For the category of "urban and built-up area", we used a method different from that of the USGS database, which just copies data from a military map (the "Digital Chart of the World", US Defence Mapping Agency, 1992). We assume that the urban area is proportional to the population density raised to some power, inspired by Tobler et al. (1995) and Waggoner (1994):

$$
\mathrm{U}=\mathrm{A} \times\left(\mathrm{P} / \mathrm{P}_{0}\right)^{-0.25}
$$

where $\mathrm{U}=$ urban and built-up area $\left[\mathrm{m}^{2} / \mathrm{cap}.\right], \mathrm{P}=$ population density $\left[\mathrm{cap} . / \mathrm{km}^{2}\right], \mathrm{P}_{0}=$ reference population density taken as 1 cap. $/ \mathrm{km}^{2}$, and where we take $A=1660 \mathrm{~m}^{2} / \mathrm{cap}$. for regions 1-4 (see Table 2) except Japan, Asian "tiger" countries, and the Middle East, and A=830 $\mathrm{m}^{2}$ /cap. for these exceptions and regions 5-6. The idea is to differentiate between regions where urban land is scarce and less scarce and to reflect diminishing per capita area use in areas of high-rise buildings. This ad hoc method gives reasonable agreement when checked with urban land use data for Buenos Aires, Lagos, Karachi and the regions of Bangladesh and Connecticut (Waggoner, 1994). Its prediction of roughly ten times higher urban and built areas than the Digital Chart of the World appears more realistic and suited for our purpose. Inside each cell, we adjusted the other land use categories proportionally to retain the correct total cell area.

Figure 13 shows our estimated fraction of land area constituting urban or built-up sites in 2050. This on average gives $236 \mathrm{~m}^{2}$ of urban/built-up land per world citizen or 4237 world citizens per $\mathrm{km}^{2}$ of urban or built-up land. This seems consistent considering the urbanisation degree in 2050, whereas the significantly lower value obtained from the Digital Chart of the World is not.

Table 8 gives the regional sums of area use and Figures 14-18 the additional land-use categories of interest to renewable energy planners. Figure 19 gives water body fractions, i.e. either rivers and inland lakes or ocean fractions included in the latitude-longitude cells at the edges of continents. Figure 20 gives the area fractions not belonging to any of the preceding categories. This includes wilderness and preservation areas, although some may be included in the other categories, notably forest and marginal land fractions. 
Table 8. Regional averages and sums of energy-supply related quantities

\begin{tabular}{|c|c|c|c|c|c|c|c|c|}
\hline Region (cf. Table 2): & 1 & 2 & 3 & 4 & 5 & 6 & Total & unit \\
\hline Region area & 20.1 & 15.4 & 28.3 & 26.3 & 20.1 & 30.9 & 141 & $\mathrm{M} \mathrm{km}^{2}$ \\
\hline Urban area fraction & 0.0063 & 0.0133 & 0.0096 & 0.0178 & 0.0290 & 0.0122 & 0.0147 & \\
\hline Cropland fraction & 0.0807 & 0.1324 & 0.1458 & 0.1714 & 0.2433 & 0.0472 & 0.1368 & \\
\hline Open cropland fraction & 0.0707 & 0.1020 & 0.1149 & 0.1107 & 0.2251 & 0.0240 & 0.1079 & \\
\hline Rangeland fraction & 0.0775 & 0.0430 & 0.0818 & 0.1115 & 0.1982 & 0.0632 & 0.0959 & \\
\hline Forest fraction & 0.3514 & 0.1500 & 0.3051 & 0.4022 & 0.1305 & 0.1727 & 0.2520 & \\
\hline Marginal land fract. & 0.1155 & 0.2166 & 0.1239 & 0.0999 & 0.3038 & 0.4058 & 0.2109 & \\
\hline Water body fraction & 0.1043 & 0.1308 & 0.0625 & 0.1148 & 0.0465 & 0.0398 & 0.0831 & \\
\hline Other landtype fract. & 0.2645 & 0.3141 & 0.2714 & 0.0824 & 0.0488 & 0.2589 & 0.2067 & \\
\hline Decentralised PV potential, January & 38.9 & 40.5 & 71.3 & 146 & 164 & 109 & 570 & GW \\
\hline Decentralised PV potential, July & 60.2 & 66.6 & 118 & 141 & 217 & 122 & 724 & GW \\
\hline Decentralised PV potential, ann. Av. & 49.5 & 53.5 & 94.5 & 143 & 190 & 115 & 647 & GW \\
\hline Centralised PV potential, January & 2220 & 7310 & 6680 & 4500 & 7910 & 18200 & 46900 & GW \\
\hline Centralised PV potential, July & 3870 & 5990 & 9460 & 3980 & 11500 & 22700 & 57500 & GW \\
\hline Centralised PV potential, annual av. & 3040 & 6650 & 8070 & 4240 & 9690 & 20500 & 52200 & $\mathrm{GW}$ \\
\hline Decentr. Wind power potential, January & 66.3 & 40.8 & 454 & 156 & 118 & 85.0 & 920 & GW \\
\hline Decentr. Wind power potential, April & 9.3 & 55.5 & 55.7 & 94.6 & 52.5 & 22.6 & 290 & GW \\
\hline Decentr. Wind power potential, July & 37.6 & 41.2 & 52.7 & 189 & 153 & 49.6 & 524 & GW \\
\hline Decentr. Wind power potential, October & 30.5 & 39.2 & 156 & 92.8 & 76.5 & 29.6 & 425 & GW \\
\hline Decentr. Wind power potential, ann. av. & 35.9 & 44.2 & 180 & 133 & 100 & 46.7 & 540 & GW \\
\hline $\begin{array}{l}\text { Off-shore/on-shore centralised wind } \\
\text { power potential, January }\end{array}$ & $\begin{array}{l}28.6 \\
28.4 \\
\end{array}$ & & $\begin{array}{l}66.5 \\
82.0 \\
\end{array}$ & $\begin{array}{r}138 \\
45.5\end{array}$ & $\begin{array}{l}10.2 \\
42.6 \\
\end{array}$ & $\begin{array}{l}8.7 \\
309 \\
\end{array}$ & $\begin{array}{l}312 \\
601 \\
\end{array}$ & $\begin{array}{l}\text { GW } \\
\text { GW }\end{array}$ \\
\hline $\begin{array}{l}\text { Off-shore/on-shore centralised wind } \\
\text { power potential, April }\end{array}$ & $\begin{array}{l}13.7 \\
11.8 \\
\end{array}$ & $\begin{array}{l}90.5 \\
183 \\
\end{array}$ & $\begin{array}{l}14.1 \\
18.5\end{array}$ & $\begin{array}{l}89.3 \\
36.7\end{array}$ & $\begin{array}{l}11.6 \\
24.4\end{array}$ & $\begin{array}{l}6.6 \\
176\end{array}$ & $\begin{array}{l}226 \\
450\end{array}$ & $\begin{array}{l}\text { GW } \\
\text { GW }\end{array}$ \\
\hline $\begin{array}{l}\text { Off-shore/on-shore centralised wind } \\
\text { power potential, July }\end{array}$ & $\begin{array}{l}7.9 \\
5.8 \\
\end{array}$ & $\begin{array}{l}98.5 \\
265\end{array}$ & $\begin{array}{c}21.4 \\
169\end{array}$ & $\begin{array}{l}139 \\
103 \\
\end{array}$ & $\begin{array}{l}50.3 \\
99.4\end{array}$ & $\begin{array}{r}21.7 \\
539 \\
\end{array}$ & $\begin{array}{c}339 \\
1180 \\
\end{array}$ & $\begin{array}{l}\text { GW } \\
\text { GW }\end{array}$ \\
\hline $\begin{array}{l}\text { Off-shore/on-shore centralised wind } \\
\text { power potential, October }\end{array}$ & $\begin{array}{l}17.0 \\
17.4\end{array}$ & $\begin{array}{l}61.2 \\
46.0\end{array}$ & $\begin{array}{l}11.5 \\
30.5\end{array}$ & $\begin{array}{l}82.6 \\
46.6\end{array}$ & $\begin{array}{c}9.0 \\
16.9 \\
\end{array}$ & $\begin{array}{l}5.3 \\
245 \\
\end{array}$ & $\begin{array}{l}187 \\
403\end{array}$ & $\begin{array}{l}\text { GW } \\
\text { GW }\end{array}$ \\
\hline $\begin{array}{l}\text { Off-shore/on-shore centralised wind } \\
\text { power potential, annual average }\end{array}$ & $\begin{array}{l}16.9 \\
15.9 \\
\end{array}$ & $\begin{array}{l}77.5 \\
147 \\
\end{array}$ & $\begin{array}{l}28.4 \\
74.9 \\
\end{array}$ & $\begin{array}{r}112 \\
58.0 \\
\end{array}$ & $\begin{array}{l}20.3 \\
45.8 \\
\end{array}$ & $\begin{array}{l}10.6 \\
317 \\
\end{array}$ & $\begin{array}{l}266 \\
659 \\
\end{array}$ & $\begin{array}{l}\text { GW } \\
\text { GW }\end{array}$ \\
\hline Hydro power potential & 90.6 & 85.0 & 52.7 & 251 & 122 & 15.0 & 616 & GW \\
\hline Potential grain/vegetable food deliveries & 153 & 176 & 215 & 369 & 546 & 90.7 & 1550 & GW \\
\hline Pot. animal food with use of crop fodder & 38.4 & 43.9 & 43.0 & 92.2 & 46.8 & 4.5 & 269 & GW \\
\hline Pot. animal food from grazing animals & 21.9 & 10.5 & 20.3 & 50.1 & 38.4 & 19.1 & 160 & GW \\
\hline $\begin{array}{l}\text { Potential biofuels from forestry waste, } \\
\text { crop residues and stable animal manure }\end{array}$ & 299 & 184 & 263 & 987 & 327 & 356 & 2420 & GW \\
\hline Of which from forestry waste & 208 & 80.4 & 154 & 769 & 157 & 333 & 1700 & $\mathrm{GW}$ \\
\hline Potential biofuels from energy crops & 98.4 & 64.1 & 67.6 & 228 & 128 & 63.6 & 650 & GW \\
\hline Of which from prime cropland & 25.5 & 29.3 & 0 & 61.5 & 0 & 0 & 116 & GW \\
\hline
\end{tabular}




\subsection{Solar power}

We have based our solar radiation model on data for solar radiation incident on a horizontal plane. One set of data is based on an analysis (Pinker and Lazzlo, 1992) of satellite measurements of radiation, albedo (reflectance) cloud cover and attenuation of radiation in the air (NASA, 1997). The other study collects many types of weather and climate data (NCEP/NCAR, 1998) and uses balance equations and a global circulation model (horizontal resolution about $210 \mathrm{~km}$ and 28 vertical levels) to improve the consistency of data (Kalney et al, 1996). However, for solar radiation no ground-based observations are used, so this is again based on top-of-the atmosphere fluxes and various absorption, reflection and attenuation processes plus the balance requirements at the Earth's surface. The two types of analysis give similar results for solar radiation. The balance equations (difference between upwards and downwards short- and long-wavelength radiation and heat fluxes) do suggest a too high albedo over oceans, but the land data that we are using appear to be reliable. Figure 12 shows the radiation on a horizontal plane at the Earth's surface for selected months of 1997 (NCEP/NCAR, 1998).

In order to calculate the solar radiation incident on inclined surfaces, such as the ones characterising most solar panel installations, one would ideally need hourly data for direct and scattered radiation (or equivalently for direct and total global radiation). One would then assume that the scattered radiation is uniform to calculate its value for differently inclined surfaces. For the direct part, ray calculations with the appropriate angles between the direction to the sun and the normal to the collector surface have to be performed hourly. Such calculations have been performed and compared with measurements on inclined surfaces at several major solar installations and some weather stations (Sørensen, 1979). Here we need global data and have at our disposal only monthly average radiation data, so an approximate relation has to be invoked.

We want to estimate the radiation on a surface tilted towards either North or South by an angle approximately equal to the latitude (as this gives the optimum performance) from the horizontal surface solar radiation data available. No great accuracy is aimed at, because the actual solar panel installations in the 2050 scenario will be of two types: 1) Building integrated panels that will anyway be influenced by the structures at hand: some solar panels will be mounted on vertical facades, others on roofs being either flat or tilted, typically by angles $30^{\circ}, 45^{\circ}$ or $60^{\circ}$. In all cases the orientation may not be precisely towards South or North, although we estimate the resource as comprising only those buildings facing approximately correct and not being exposed to strong shadowing effects from other structures. The penalty of incorrect orientation and tilting angle is often modest and mostly influences the distribution of power on seasons (Sørensen, 1979). 2) Centralised solar farms will generally be oriented in an optimum way, using total production maximising for panels not tracking the sun. However, the majority of locations suited for central photovoltaic (PV) installations will be the desert areas of Sahara, the Arabian Peninsula, the Gobi desert and Australian inland locations. As these are all fairly close to the Equator, there is modest seasonal variations in solar radiation, and the horizontal surface data are often quite representative.

In consequence of the many unknown factors regarding the precise inclination of actual installations, we use the following simple approximation originating from an analysis of the Danish (latitude $56^{\circ} \mathrm{N}$ ) data of Sørensen (1979). Here the radiation on a latitude inclined surface in January and July very nearly equals the horizontal radiation in October and April, whereas the horizontal surface data for January and July are lower and higher than the inclined surface measurements, respectively. We therefore use the October and April horizontal data as a proxy for January and July inclined surface radiation, and construct the April and October inclined surface values as simple averages of the January and July adopted values. 
This procedure, which works well for the Danish latitude, will also be less inaccurate for low latitudes, because of the relative independence of seasons mentioned above, and we simply use it for all locations.

Figure 21 shows the NCEP/NCAR (1998) data for a horizontal surface. We have checked these against the European general circulation model HADCM2-SUL (Mitchell and Johns, 1997), and found the 1997 monthly solar radiation values very similar .

In order to derive the actual energy extracted from PV solar panels, we assume a fixed conversion efficiency of $15 \%$, which is a fairly conservative estimate for year 2050 technology, considering that the current efficiency of the best mono-crystalline cells is above $20 \%$ and that of amorphous cells near $10 \%$, with multicrystalline cells falling in between. The 2050 technology is likely to be thin-film technology, but not necessarily amorphous, as new techniques allow crystalline or multicrystalline material to be deposited on substrates without the complicated process of ingot growth and cutting. The efficiency of such cells is currently low, but as they are much less expensive than crystalline cells, they may be stacked in several layers and thereby still reach the efficiency that we envisage (Pacific Solar, 1997).

Finally, we estimate the availability of sites for mounting PV panels either in a decentralised fashion or centrally in major energy parks: The decentralised potential is based on availability of suitably inclined, shadow-free surfaces. We assume that the area of suitably oriented surfaces that may be used for building-integrated PV energy collection is $1 \%$ of the urban horizontal land area plus $0.01 \%$ of the cropland area. The latter reflects the density of farmhouses in relation to agricultural plot sizes and is based on European estimates, roughly assuming that $25 \%$ of rural buildings may install solar panels. The potential PV production is thus taken as $15 \%$ of radiation times the fraction of the above two area types and the stated percentage for each. A final factor of 0.75 is applied in order to account for transmission and storage cycle losses, assuming about $5 \%$ transmission losses and that roughly half the energy goes through a storage facility of $60 \%$ round-trip efficiency (e.g. reversible fuel cells). The flow of energy reduced by all these factors represents the energy delivered to the end-use customers in the form of electricity. It is shown in Figure 22 for each season, with regional sums given in Table 8.

For centralised PV, we give the potential as $1 \%$ of all rangeland plus $5 \%$ of all marginal land (deserts and scrubland), again times $15 \%$ of the incoming radiation and times 0.75 to account for transmission and storage losses. As shown in Figure 23 and Table 8, this is a huge amount of energy, and it shows that such centralised PV installations can theoretically cover many times the demand of our 2050 scenario. Setting aside $1 \%$ of rangeland would imply an insignificant reduction in other uses of the land, even if this would rather be a small number of large plants. The same is true for desert and marginal land, where only the $5 \%$ most suited need to be invoked, which in reality might be $10 \%$ for the entire installation (including frames, access roads), of which the solar panels is only part. Because of the huge area of e.g. the Sahara desert this would suffice to supply more than the entire world need for energy. Of course an implication is the availability of intercontinental transmission, which may be quite realistic by year 2050, e.g. through superconducting trunk lines (Nielsen and Sørensen, 1996).

\subsection{Wind power}

The data we use to assess potential wind power production are 1997 values from a reanalysis of meteorological station data and elevated data from balloons and aircrafts, analysed according to the method of Kalney et al., (1996), using a general circulation model to improve consistency (NCEP/NCAR, 1998). We use a simple average of pressure level $1000 \mathrm{mb}$ and 
$925 \mathrm{mb}$ data to represent the wind speeds at typical turbine hub heights of around $70 \mathrm{~m}$. However, as the data are monthly mean wind speeds $\langle v\rangle$ constructed on the basis of zonal and meridional winds, we need a model of the relationship between $\langle v\rangle^{3}$ and $\left\langle v^{3}\right\rangle$ go go from wind speeds to power in the wind. Simple models imply a rough proportionality between these two quantities, as used e.g. in the US wind atlas prepared by the Pacific NW Laboratory (Swisher, 1995) and also apparent from the Weibull distribution approach of the European wind atlas (Troen and Petersen, 1989). Inspired by these sources we estimate the relation between the power in wind $P_{w}$ and the wind speed $v(\mathrm{~m} / \mathrm{s})$ from the relation

$$
\left.\left.\mathrm{P}_{\mathrm{w}}=0.625<\mathrm{v}^{3}\right\rangle \approx 1.3<\mathrm{v}\right\rangle^{3} \mathrm{~W} / \mathrm{m}^{2} \text {. }
$$

The power in the wind obtained in this way is illustrated in Figure 24, for four seasons.

Going from the power in the wind to the power that may be produced by a wind turbine, the non-linear response of wind turbines has to be taken into consideration. Turbines of modern designs aim at a high annual production and typically start producing only around $5 \mathrm{~m} / \mathrm{s}$ and reach a fixed maximum production at around $12 \mathrm{~m} / \mathrm{s}$. Thus there would not be any production for a monthly average windspeed below $5 \mathrm{~m} / \mathrm{s}$, if this were made up of nearly constant values throughout the time range. However, actual time series of wind speeds reflect the passage of weather fronts and typically oscillates with periods of some two weeks, and actually entails some power production from the above type of wind turbine at practically all monthly average wind speeds, down to zero. The approach is then to parametrise the average power production from wind turbines as

$$
\mathrm{W}_{\mathrm{p}}=\operatorname{Minimum}\left(0.33 \mathrm{P}_{\mathrm{w}}, 500\right) \mathrm{W} / \mathrm{m}^{2} \text {, }
$$

representing the 21 st century wind turbine constructions through a power factor slightly above the best of the current ones. A survey of power curves from existing wind turbines (Petersen and Lundsager, 1998) has been used as a basis for this estimate. This simple model is in reasonable agreement with data in regions of present wind exploitation. Due to the coarseness of the GIS grids used (for the wind speed data about $300 \mathrm{~km}$ cells at the Equator, diminishing by a cosine of the latitude towards the poles), the method does not at present compete with wind atlas methods available in certain parts of the world. It is, however, suited for planning purposes and can be refined as needed. The use of general circulation models in recalculating the data ensures that both surface roughness and general circulation determinants are included.

The wind power estimates calculated from the US data have been checked by performing a similar calculation using the HADCM2-SUL model of the European Hadley center (Mitchell and Johns, 1997; IPCC Data Distribution Centre, 1998), giving substantial agreement, within the variability from year to year which is of course different in the Hadley model from the NCAR model that is based on actual measurements. The year 1997 is about $10 \%$ under the long-term average for Danish locations (according to the data collected by Naturlig Energi, 1998), but the monthly variations are somewhat untypical. For instance the average of the four months included in our model is $20 \%$ under the long-term average. The previous year (1996) was the poorest wind year of the 20-year survey, and we wanted to include realistic seasonal variations in our data set and thus avoided further averaging. It should be said that the data from ground based stations (which has a substantial impacts on the NCEP/NCAR data set due to the large number of such measurements relative to elevated data) may be a poor representation of actual wind conditions in a given area, due to the sheltered location of many meteorological measuring station. For this reason the European wind atlas used only selected station data believed to be more relevant for wind turbine exploitation. However, our comparison with the Hadley data, which only have a weak dependence on station data, because they are generated from a general circulation model using topological features of wind 
roughness (friction), indicates that the method is quite reliable. The reason for this is presumably that we use pressure level data for both of the two lowest model pressure levels, rather than the $10 \mathrm{~m}$ data also available in the NCEP/NCAR data base. We have performed our type of calculation also for the $10 \mathrm{~m}$ data and find a considerably stronger dependence on the dubious ground level measurements.

The final step in estimating potential production from wind turbines is to appraise the locations suited for erection of wind turbines. We divide this into three categories: Decentralised wind power production on farmland and centralised production in wind parks, either on-shore or off-shore. For the decentralised production, we assume that a (vertical) turbine swept area amounting to $0.1 \%$ of the crop- and rangeland areas may be used for wind production. We include only the part of cropland designated as "open cropland" (cf. Figure 15). This excludes mixed forest and cropland, where the trees are likely to impede wind flow. The assumed density of turbines corresponds roughly to the current density of wind turbines in many parts of Denmark, although the current average size is smaller than the turbines envisaged for the mid- $21^{\text {st }}$ century.

Current new turbines are typically of unit size $1.5 \mathrm{MW}$ and have hub-heights of $50-60 \mathrm{~m}$, while the average standing wind turbine is around $500 \mathrm{~kW}$ with a hub-height of around $40 \mathrm{~m}$. Due to the combination of swept area increasing as the square of the linear dimension, and wind speeds increasing with height, the $2-4 \mathrm{MW}$ turbines envisaged in the 2050 scenario will not be conspicuously larger than those of the current generation. We therefore assume that visual intrusion aspects will allow a turbine density similar to the present one. Other environmental concerns such as noise are very minor, as the present generation of turbines can be heard only a few rotor diameters away at levels significantly exceeding the background noise (wind passing trees and structures such as power lines, highway signs and buildings) (Sørensen, $1995 ; 1997)$. In terms of ownership, the density of decentralised turbines would correspond to one out of 5-10 farmers owning a wind turbine (with large variations due to farm size variations between regions). Current wind power utilisation in the country with highest per capita wind power production, Denmark, are still dominated by farm-attached wind turbines, while in many other countries, the emphasis has been on centralised production from turbine clusters. The amounts of decentralised wind power potentially available is shown in Figure 25 and summarised on a regional level in Table 8.

By centralized wind power we shall understand power not produced in connection with individual farms. For land-based wind parks, we shall accept only placement on marginal land in our scenario. In contrast to photovoltaic power, there is a fundamental limit to the fraction of land that can be used for wind power extraction, due to shadowing and interference between wake flows that create turbulence and reduce the power output. This limit would be a vertical swept area of about 1\% of the horisontal land area (Sørensen, 1995). We assume that only $10 \%$ of the marginal land areas are used for placement of wind turbines at such spacing, implying a maximum wind swept area constituting $0.1 \%$ of the land area. This is small enough not to interfere with other uses of the marginal land, such as the solar cell parks considered in section 4.1. Figure 26 gives the seasonal and annual production that potentially may be derived from such wind parks, with regional summaries in Table 8.

Finally, there is off-shore wind parks, meaning turbines placed in shallow waters at a distance from the shore that minimises visual impacts. This mode of wind utilisation has become popular in recent years, as innovative low-cost solutions to the off-shore foundation problem have been found (Sørensen, 1995). We here estimate the potential by first identifying all offshore water bodies with a depth under $20 \mathrm{~m}$ (Figure $12 \mathrm{a}$ ). Of these, we assume that only $10 \%$ can be used for wind power generation, due to competing uses (fishing, military, ship routes, etc.). Taking again the $1 \%$ maximum utilisation rate imposed by turbine interference into ac- 
count, we arrive at a $0.1 \%$ maximum use of off-shore locations for wind power extraction. The average amount of power that can be derived from these locations is shown in Figure 27 and summed up on a regional basis in Table 8. As indicated in the area fraction data of Table 8 and in Figure 19, there are an additional number of inland water bodies that could also be used for wind power production. We have chosen to disregard these as candidates for wind production, as such lake and river areas are often of great recreational value.

\subsection{Biomass energy}

The largest current use of renewable energy sources is in agriculture. Although the primary aim is food production, increasing amounts of residues are made useful for energy purposes and as feedstock in manufacturing industries. The same is true for fisheries and silviculture, where again the aim is to make productive use of the entire variety of products associated with biomass. The technologies employed have also changed in response to environmental concerns, from simple burning of straw and woodfuel to production of new bio-derived fuels, e.g. ethanol, methanol, methane and hydrogen. We shall generally assume that biomass used in a "decentralised" mode means using the land areas already devoted to agriculture and forestry, possible for other crops than those grown today and farming in a more efficient manner. Like for solar and wind power we then add some further potential uses that we denote "centralised", meaning in the biomass case cultivation of dedicated energy crops or energy forest.

The general model used for the biomass sector is shown in Figure 28. It is a refinement of a model developed earlier (Sørensen et al., 1994; Sørensen, 1995b). Below we explain each part of the model and give the numerical assumptions made.

\subsubsection{Food production}

The land area used for food crops is considered to be the same in 2050 as now. This primarily includes the cropland area fraction $(A F$ in Figure 28 ) given in Figure 14, and for grazing also the rangeland shown in Figure 16. Some of the latter is today used for grazing in a little intensive way, in contrast to the use of cropland in rotation for occasional grazing. Crop cultivation on the cropland fraction is in some areas (e.g. Africa) little intensive, and present yields strongly reflect the agricultural practices of each region. As an indication of the potential biomass production on these areas we use calculated net primary production data from the "Terrestrial Ecosystem Model (TEM)" of the Woods Hole group (Melillo and Helfrich, 1998; model evolution and description in Raich et al., 1991; Melillo et al., 1993; McGuire et al., 1997; Sellers et al., 1997). Global warming may induce increased primary production in a fairly complex pattern and the borders of natural vegetation zones will change, sometimes by several hundred kilometres (IPCC, 1996).

We have not considered any greenhouse warming induced change in area fractions, as we consider farming practice to be able to gradually replace the crops cultivated in response to such altered conditions, which are anyway long-term compared to the lives of annual crops. Our model does not specify which crops will be cultivated at a given location, but simply assumes a productivity consistent with growing crops suited for the conditions. The TEM data are for a mature ecosystem, taking into account natural water, humidity and nutrient constraints along with solar radiation and temperature conditions. Annual crops are likely to have smaller yields, because of only partial ground cover during part of the year and the corresponding smaller capture of radiation. On the other hand, the crops selected for cultivation may be favourably adapted to the conditions and therefore give higher yields than the natural vegetation at the location. Furthermore, irrigation may prevent yield losses in dry periods, and application of chemical fertilisers may improve overall yields. 
The value basis of our 2050 scenario implies restrictive use of these techniques and suggests a move towards increased use of the ecological agriculture principles currently showing at the $10 \%$ level, area-wise, and mostly in Europe. We shall assume what is called "integrated agriculture" (Danish Technology Council, 1996), a concept where use of pesticides is banned and recycled vegetable residues and animal manure are the main sources of nutrient restoration, but where biological pest control and limited use of chemical fertilisers are not excluded. The yield losses implied by this method of farming is under $10 \%$, according to current experience.

On cultivated land (including grazing land and managed forests) in regions such as Denmark, characterised by modest radiation and good soil and water access, the average annual biomass production is $0.62 \mathrm{~W}$ per $\mathrm{m}^{2}$ (of which $0.3 \mathrm{~W} / \mathrm{m}^{2}$ are cereal crops; Sørensen et al., 1994). This is exactly the value for a grid cell in Denmark given in the TEM database for mature natural productivity. In Southern Europe the current production is about half (Nielsen and Sørensen, 1998), while the TEM database gives a slightly higher value than for Denmark. The reasons for this are less intensive agricultural practice in Southern Europe and water limitations for the growth pattern of the crops cultivated (limitations that would be less severe for a mature ecosystem). It thus seems reasonable in the scenario to use the TEM as a proxy for cultivation yields, provided than one assumes better farming techniques used by year 2050 , and assumes that irrigation and chemical fertilisers are used when necessary. This is precisely the assumptions stated above as the basis for our scenario. We thus use the net natural primary production data of the TEM globally, but without adding further increases on the basis of irrigation (which in dry regions can double agricultural output) and use of chemical fertilisers (which can provide a further doubling, if the soil is poor in nutrients or nutrients are not returned to the fields). In other words, we offset the disadvantage in going from mature vegetation to annual crops against the advantage of reducing limiting factors related to water and nutrients. In Figure 28, this means disregarding the irrigation and fertiliser parameters $I F$ and $F I$, and proceeding with the potential production $P P$ taken from the TEM database.

The TEM global biomass production estimates for $P P$ are shown in Figure 29 expressed in energy units ( 1 gram carbon per year is equal to a rate of energy production of $0.00133 \mathrm{~W}$ ).

Currently, in Denmark only about $10 \%$ of this energy is contained in the food consumed domestically. The indication from this is, that there is room for altered management of the system, by diverting residues to energy extraction and later returning the nutrients to the fields. One may also note, that the current system is based on high meat consumption and the associated emphasis on animal raising, and in the Danish case export. By even the modest change in vegetable to animal food consumption ratio, that we have assumed in our demand scenario, it is possible globally to divert substantial amounts of biomass to energy purposes, without jeopardising the need to provide food for a growing world population.

We do not assume that the intensive agricultural practices of Northern Europe will have been adopted globally by year 2050 . The agricultural efficiency factor $A E$ in Figure 28 is taken as unity only for regions 1 and 2 (cf. Table 2). For Africa (region 6) it is taken as 0.4 and for the remaining regions as 0.7 . The fraction of the biomass production actually harvested is taken globally as $H F=0.4$. The remaining fraction consists of roots and residues plowed down in order to provide natural fertilisation for the following growth season.

Regarding the land areas classified as cropland, we assume the distribution on uses given in Table 9, based on cropland scarcity and traditions for animal raising. The low animal fodder value for Africa reflects the fact, that the African tradition for animal raising is based on rangeland, not cropland providing fodder. 
Table 9. Parameters used for cropland biomass production in 2050 scenario (cf. Figure 28)

\begin{tabular}{|c|c|c|c|c|c|}
\hline Region & AE(cropland) & HF & UF (veget. food) & UF (fodder) & UF (energy crops) \\
\hline 1 & 1 & 0.4 & 0.4 & 0.5 & 0.1 \\
\hline 2 & 1 & 0.4 & 0.4 & 0.5 & 0.1 \\
\hline 3 & 0.7 & 0.4 & 0.5 & 0.5 & 0 \\
\hline 4 & 0.7 & 0.4 & 0.4 & 0.5 & 0.1 \\
\hline 5 & 0.7 & 0.4 & 0.7 & 0.3 & 0 \\
\hline 6 & 0.4 & 0.4 & 0.8 & 0.2 & 0 \\
\hline
\end{tabular}

The amounts of vegetable type food that can potentially be produced and delivered to the endusers in this scenario can now be calculated on an area basis, assuming the losses in going from vegetable food produced to vegetable food delivered as $25 \%$ (IE(veg. products) $=0.75$ for vegetable food products in Figure 28),

Delivered vegetable food $=A F$ (cropl.) $\times P P[W / m 2] \times A E \times H F \times U F$ (veg. food) $\times I E($ veg. prod.),

where $A F$ and $P P$ depend on the precise geographical location, the others only on region. The calculated distribution of vegetable food delivered to the consumers is shown in Figure 30, and the regional totals are given in Table 8.

For food from animals, such as meat, milk and eggs, the average efficiency in transforming biomass to delivered animal products is assumed to be $I E$ (animal products) $=0.15$, a value reflecting a typical average of a smaller efficiency for meat production and a higher one for milk and eggs (Sørensen et al., 1994). The amounts of animal-based food using croplandderived fodder and delivered to the consumer is thus

Delivered animal food(1) $=A F($ cropl.) $\times P P[W / m 2] \times A E \times H F \times U F$ (fodder) $\times I E$ (anim. prod.).

The distribution of potential animal food deliveries based on the route where livestock is fed fodder produced on cropland is shown in Figure 31 and summarised in Table 8.

The other part of animal food is from animals grazing on rangeland, where we shall assume that livestock grazes $H F=0.4$ of the biomass production per unit of area, and put $A E=1$. The use of rangeland is assumed to be $50 \%$ for grazing and $50 \%$ for other purposes (such as energy crops or no commercial use). Thus the utilisation factor is taken as UF(grazing) $=0.5$ :

Delivered animal food(2) $=A F($ rangeland $) \times P P[W / m 2] \times H F \times U F($ grazing $) \times I E($ anim. prod.) .

The distribution of potential animal foodstuff delivered to the end-users through the route of rangeland grazing is shown in Figure 32 and again summarised in Table 8. The ratio of the two contributions (crop feeding and grazing routes) is determined by the area set aside for each. The resulting fraction of animal food derived from rangeland grazing is $37 \%$, in terms of energy content.

The efficiency in the end-user's making use of the delivered food, denoted $E E$ in Table 28, has for all the bioenergy routes been included in the definition of gross demand in section 3 .

\subsubsection{Biofuel production}

A number of fuels may be produced from biomass and residues derived from vegetable and animal production, or from forestry and dedicated energy crops, ranging from fuels for direct combustion over biogas (mainly methane mixed with carbon dioxide) to liquid biofuels such 
as ethanol or methanol, or gaseous fuels such as synthesis gas (a mixture of mainly carbon monoxide and hydrogen, also being an intermediate step in producing methanol) or pure hydrogen. The production of biofuels by thermochemical processes is based on hightemperature gasification and various cleaning and transformation processes (Jensen and Sørensen, 1984; Nielsen and Sørensen, 1998).

Whether the biofuel production is by thermal or biological processes, the expected conversion efficiency is of the order of $F E=50 \%$ (cf. Figure 28). This is to be compounded with a factor describing the ability of the biofuel production industry to collect the necessary feedstocks. This collection efficiency factor, which we call $C F$, describes the efficiency in collecting biomass for such industrial uses. For vegetable foods, we shall assume that $C F$ (veg. waste) $=$ $25 \%$ of the gross production is available for energy production (some of this would come from the food industry losses of $(1-I E(v e \bar{g}$. prod. $))=25 \%$, some from the subsequent household losses of $30 \%$, cf sections 3.2 and 4.3.1). The overall yield of biofuels from vegetable crops is then

\section{Biofuels from vegetable foodcrops $=$ \\ $A F($ cropl. $) \times P P[W / m 2] \times A E \times H F \times U F($ veg. food $) \times C F($ veg. waste $) \times F E$.}

Considering manure, this would be available only when livestock are in stables or otherwise allows easy collection. We shall assume that grazing animals leave manure in the fields and that this is not collected (although it could be in some cases), but that animals being fed fodder from crops will be in situations where collection of manure is feasible. Furthermore, although the $85 \%$ of animal biomass not ending up in food products will both be used to maintain the metabolism of livestock animals and the process of producing manure, it will also contain a fraction that may be used directly for fuel production (e.g. slaughterhouse wastes). Combined with manure we assume that this amounts to $C F$ (anim.) $=0.6$, giving for the fodder to animal route to biofuels:

\section{Biofuels from manure and other animal residues $=$ $A F($ cropl. $) \times P P[W / m 2] \times A E \times H F \times U F($ fodder $) \times(1-I E($ anim. prod. $)) \times C F($ anim. $) \times F E$}

The further possibility of producing biofuels from forestry residues (either scrap derived from the wood industry or residues collected as part of forest management) may be described by a factor $C F$ (forestry) $=0.3$, defined as a percentage of the total forest biomass production. This is the fraction collected, expressed in energy units. For managed forests it depends on the fraction of wood being suitable for the wood manufacturing industry (furniture etc.), which again depends on the tree type. Adding wood scrap from industry and discarded wooden items, as well as from forest management would in many regions exceed $30 \%$. However, we are starting from an enumeration of all forests, including the rainforests and other preservation-worthy forest areas that we do not propose to touch, and considering only managed forests that deliver to wood industries, $30 \%$ is probably a maximum for year 2050 . The forest residue to biofuel route is then

Biofuels from forest management $=$

$$
A F \text { (forestland) } \times P P[W / m 2] \times H F \times U F \text { (fodder) } \times C F \text { (forestry) } \times F E
$$

The potential amounts of biofuels that could be derived from forestry are shown in Figure 33, and the sum of the three routes to biofuels described above are given on an area bases in Figure 34. This we denote "decentralised fuel production", although forestry may not be seen as entirely decentral in nature. However, it is an ongoing activity and distinct from producing biofuels from land used exclusively for energy crops. We include two energy crop routes: 
While the biomass production on rangeland does not give rise to biofuel production because manure from grazing livestock is not collected, some of the rangeland may be suited for cultivation of dedicated energy crops. As we have only assumed $50 \%$ used for grazing, we shall consider the remaining $50 \%$ as potentially exploitable for energy purposes, in the scenario versions where centralised energy schemes are found acceptable (i.e. UF(rangeland energy crops $)=0.5$ ). On cropland we have also assumed $10 \%$ set aside to energy crops in areas of generous resources, such as Western Europe and the Americas (see the UF(cropland energy crops) values of 0.1 or 0 in Table 9). The potential biofuel production from these areas is

Biofuels from energy crops on cropland $=$

$A F($ cropl. $) \times P P[W / m 2] \times A E \times H F \times U F$ (cropland energy crops) $\times F E$,

Biofuels from energy crops on rangeland $=$

$A F$ (rangeland) $\times P P[W / m 2] \times H F \times U F$ (rangeland energy crops) $\times I E$ (anim. prod.).

The area distribution of these two potential sources of biofuels from energy crops is shown in Figure 35, with regional sums in Table 8.

\subsection{Hydro power}

For hydro power, which in the past has often been used in a way not compatible with environmental considerations (flooding areas of high landscape value, dislocating people, etc.), we consider that it is a renewable energy source worthy of inclusion in a sustainable scenario, provided that it is used with proper considerations. These include modular construction of large plants (cascading the water) allowing a highly reduced disturbed area, and planned location of reservoirs in locations where there is little conflict with preservation concerns, even if the water transport layout may become more complex and expensive. We include in the 2050 scenario all existing plants and plants under construction (because attempts to close plants and revert to pre-hydro landscapes have proved to entail negative environmental effects quite similar to the original change in the opposite direction, due to the already completed adaptation of flora and fauna to the changed conditions). We also include small-scale hydro planned in several countries, considering the impacts to be acceptable for most schemes. As regards total potentials identified and actual schemes proposed but not started, we modestly include only those for which actual proposals including environmental statements exist. As a source for such appraisals of the potential hydro generation we have used a survey made by the World Energy Council (1995). Including all their categories would roughly double the current hydro power generation. Figure 36 show the distribution of this potential power generation on countries. A large fraction of the installations are or will be reservoir-based, so no additional storage cycle is considered necessary (although pumped hydro would be an obvious option). Figure 37 shows the average generation from existing hydro plants plus those under construction, again averaged over country areas.

We have not attempted to show the actual reservoir areas on the map, which just spreads the power production evenly over each country. In any case most hydro is a centralised resource, that is not (and largely cannot be) used by the local population. The regional sums in Table 8 show that South America is the most endowed region, implying that the utilisation choices made in this region will be decisive.

\section{MATCHING SUPPLY AND DEMAND}

We now have available a demand scenario for the year 2050 , and estimates of potential renewable energy generation for the same period of time, divided into decentralised and cen- 
tralised supply. Both are on a geographical basis. The next task is to match supply and demand, adding new system components if necessary, e.g. when the energy form supplied is not that demanded, and pointing out requirements for energy imports and exports, when the location of supply and of demand is not the same. In practice the form of transport will depend on the type of energy (electricity transmission, gas piping, heat in district lines, or fuels to be moved e.g. by vehicle or ship). Also temporal mismatch can be identified, and energy storage requirements determined. In many cases, we already incorporated some storage cycle in the supply estimates, notably for those renewable energy sources where the source variability already indicated a storage need. We shall first perform the supply-demand matching using only those amounts of renewable energy that are estimated to be available locally, in a decentralised form (as pointed out in the resource appraisal of section 4), and then look at possible advantages of including also centralised production.

\subsection{Decentralised renewable energy 2050 scenario}

The demand categories have already, as shown in Table 6, been simplified under the assumption of an abundant fraction of the supply being in the form of electric energy. We now determine the sources of supply for each demand type.

For the vegetable food-fraction, the results of comparing local supply and demand are shown in Figures 38 and 39, where Figure 38 shows the amount of surplus for those geographical grid cells, where supply exceeds demand, and Figure 39 shows the amount of deficit for those local cells where demand exceeds supply. Regional sums are given in Table 10, while the sums of individual contributions to demand and supply are given in Tables 6 and 8. It follows that on average, worldwide supply exceeds demand by $35 \%$. This must be considered reasonable, as there has to be room for variations in crop harvests and thus food production from year to year, and further the transportation required for evening out supply and demand will entail some additional losses. Like today, there is surplus vegetable food production in the Americas and Western Europe (regions 1, 2 and 4), and by year 2050 also in region 3 (including Russia), due to substantial improvements in agricultural practices assumed for this region. Region 5 (including China and India) will be just self-sufficient by year 2050 , whereas Africa (region 6) will have a deficit that must be covered by imports. In the scenario, Africa is the only region that by 2050 is in a development situation where it may offer labour at lower expense that the other regions, and thus there will be the possibility of paying for food imports by industrial revenues, provided that an education policy is pursued, that will give the working force the necessary skills. In addition to inter-regional exchange, Figures 38 and 39 indicate scenario requirements for transport of vegetable food within regions, especially from farming areas into cities. The scenario assumptions for inter-regional trade in food is indicated in Figures 55-60, where the regional exports have been selected from the surpluses available. The substantial needs for both vegetable and animal foods in Africa are uniformly imported from regions 1-4.

For animal-based food from either rangeland or fodder-fed animals, the surpluses and deficits are shown in Figures 40 and 41 . The picture is similar to that of vegetable foods, with surpluses in the first 4 regions, but here with deficits in both region 5 and 6 . This is due to the increase in the meat and milk fractions of diets assumed for Asia (Table 6), but the amounts are easily covered by imports from other regions, as indicated in Figures 55-60. Overall, the animal food supply exceeds demand by $27 \%$, which again is considered adequate, e.g. in view of additional transportation losses. Here variations between years are smaller than for primary crops (because of the storage functions performed by livestock), but fairly frequent epidemics of animal disease are known to require a reserve. 
Figures 42 and 43 show the surplus and deficit of potential liquid biofuels derived from agriculture and silviculture, relative to the energy demand for transportation. The assumed fraction of biofuels used in this way is $48.5 \%$ (chosen such that the global average demand is covered), the remaining is considered going into industrial uses such as medium-temperature process heat, where it is assumed used with $90 \%$ efficiency. When constructing the demand scenario, we left it open to which extent electric vehicles would be used, but the availability of liquid biofuels is such, that they could cover all transportation needs (with methanol use in fuel cells determining the assumed conversion efficiency). However, the regional supplydemand situation is such, that substantial energy imports into region 5 are necessary. As we shall see below, this requires that as much energy trade as possible is based on biofuels, and hence dictates a large electricity use in the transportation sector of the exporting regions.

The deficits in Figure 43 are in urban areas and areas without biomass growth (e.g. Andes and Saudi Arabia), and in large parts of India. On average globally surplus and deficit balance, as seen from Table 10 or by comparing Tables 6 and $48.5 \%$ of the potential biofuel from decentralised sources estimate given in Table 8. There is surplus only in South America and Africa, while the numbers for North America balance, those for region 3 almost balance (and are remedied in the scenario shown in Figure 57 by increasing the fraction going into the transportation sector), whereas region 5 (including China and India) has a deficit of some $65 \%$. The high production value for South America is related to the high forest productivity, and one may consider part of this as difficult to realise, without imposing on (what should be) preservation areas. However, as we shall see, exports from South America of biofuels to the lacking regions in Asia are essential. Other areas of the model, such as regions 2 and 3 which also have average deficits, would have to import from regions 1 and 4 , albeit on a smaller scale. As explained below, the actual scenario will not use the $48.5 / 51.5 \%$ split of the biofuel use, notably because electric vehicles take over some of the transportation demand.

The remaining energy produced is in the form of electricity. Figures 44-53 show surplus and deficit, for each of the four seasons and as an average, in produced electricity plus the $51.5 \%$ of biofuels that in the initial asessment is not used by the transportation sector, relative to demand for electricity and all other energy not covered above. The regional summaries are given in Table 10. Although annual totals are in balance, there are very large mismatches both on a spatial and temporal scale. Consistent surpluses of electricity production occur in the Americas and Africa, and large, consistent deficits in region 5 (notably India and China). Western Europe exhibits small deficits, and region 3 strong seasonal variations, adding up to a substantial annual surplus. The reason is seen from Table 8 to be the variation in wind power production, which it ten times higher in January than in April. This is true for the year 1997, from which wind data were taken, but variations between years are large, implying considerable instability of power supply in region 3. A reason is that continental winds in the Eurasian continent are less persistent than West European coastal ones. The implication of the low wind power production in April in region 3 is that there is a substantial global deficit of power, affecting mostly region 5 , which might have depended on imports from region 3 .

Both the Figures and Table 10 shows, that the large exchange of decentralised power that would solve the global mismatch problem would have to be from North and South America and Africa to South-East Asia. This is a little feasible proposition, unless a global, superconducting transmission grid would be established before year 2050. It would also appear that this level of inter-continental exchance is contrary to the idea of mainly local supply underlying the decentralised scenario. In the following subsection, we shall see what easement of the uneven supply situation can be expected, if also a certain amount of centralised renewable energy production is permitted. 
In constructing the actual scenario, we first try to make as much biofuels available for export to region 5 as possible, because fuels can easily be transported over long distances (by ship), in contrast to electricity, where we assume that even superconducting transmission will not by 2050 be feasible, say from South America to India or China. The regional scenario details shown in Figures 55-60 indicate the assumed regional shift in biofuel and electricity use, that allows larger amounts of biofuels to be exported to region 5. Basically, electricity is allowed to enter the transportation sector through electric vehicles used for all urban transport as well as track-based regional transport, except for region 5, which has to use the biofuels imported. As even the necessary electricity demand in region 5 is larger than what can be produced locally, the decentralised scenario can only be realised if there is enough biomass (after imports) in region 5 to allow the missing electricity to be generated from biofuels. Since there is $a_{1}$ loss in converting fuels to electricity, and since there was just enough biofuels available globally before redistribution, according to the assumptions of the decentralised scenario, this simply cannot be done. A solution would be to relax the assumptions restricting the decentralised energy production, or alternatively to introduce a little centralised energy.

We have chosen to the latter option, adding some photovoltaic power production in region 5 not based on building-integrated installations. This is a highly available resource, and there are more than enough areas available to make up for the electricity deficit (see the potential shown in Figure 8). Still, it does negate the philosophy of all energy being produced locally, but this is probably less unacceptable than the huge imports and exports of fuels, which is necessary in this scenario, and which introduce a dependency on non-local resources difficult to reconcile with the value basis of the decentralised scenario.

Figure 54 summarises the decentralised scenario and Figures 61 shows the main flows of inter-regional energy trade.

Table 10. Balance of potential regional supply in decentralised mode, and demand.

\begin{tabular}{|l|c|c|c|c|c|c|c|c|}
\hline Region (cf. Table 2) & $\mathbf{1}$ & $\mathbf{2}$ & $\mathbf{3}$ & $\mathbf{4}$ & $\mathbf{5}$ & $\mathbf{6}$ & Total & unit \\
\hline Vegetable food & 108 & 113 & 91 & 192 & 40 & -140 & $\mathbf{4 0 2}$ & $\mathrm{GW}$ \\
\hline Animal food & $\mathbf{4 3}$ & 31 & 16 & 91 & -63 & -27 & $\mathbf{9 1}$ & $\mathrm{GW}$ \\
\hline $\begin{array}{l}\text { Transportation (relative to } \\
\text { 48.5\% of biofuels) }\end{array}$ & $\mathbf{9}$ & -69 & -19 & 202 & -230 & 112 & $\mathbf{2}$ & $\mathrm{GW}$ \\
\hline All other energy, annual av. & 123 & -14 & 103 & 528 & -879 & 201 & $\mathbf{7 2}$ & $\mathrm{GW}$ \\
\hline All other energy, January & 106 & -71 & 297 & 559 & -1000 & 234 & $\mathbf{1 0 0}$ & $\mathrm{GW}$ \\
\hline All other energy, April & 101 & -3 & -16 & 488 & -900 & 165 & $\mathbf{- 1 6 5}$ & $\mathrm{GW}$ \\
\hline All other energy, July & 155 & $\mathbf{2 6}$ & 37 & 577 & -750 & 213 & $\mathbf{2 5 3}$ & $\mathrm{GW}$ \\
\hline All other energy, October & 129 & -8 & 93 & 489 & -800 & 191 & $\mathbf{9 8}$ & $\mathrm{GW}$ \\
\hline
\end{tabular}

"All other" energy supply includes electricity from hydro, solar cells and wind turbines, plus $51.5 \%$ of biofuels.

"All other" demand comprises electricity for heat pumps supplying heating, cooling and low-temperature heat, medium- and high-temperature energy, stationary mechanical energy, and electricity for appliances and other apparatus, including refrigeration.

\subsection{Centralised renewable energy 2050 scenario}

By the "centralised" scenario we shall understand a scenario exploiting central supply installations in addition to the decentralised ones, and with a new attempt to optimise the amounts obtained from each category and the trade between regions. Section 4 has provided estimates of the total additionally exploitable resources available in a centralised mode. Their combined 
magnitude is of the order of ten times the 2050 average demand, and the regional distribution, particularly of the potential photovoltaic power production, is fairly even.

A natural approach to choosing the sources to employ in addition to the decentralised ones is the following: For hydro power, the existing plants and those already under construction are retained, but no additional plants are built, in consideration of the environmental impacts that may be caused. The bulk of the remaining resources shown in Figure 36 are large-reservoir type hydro sites, notably in South America.

Wind turbines not attached to farm buildings are introduced: In Western Europe, part of the substantial off-shore wind potential should first be put into operation, because this is already economical and installation is in progress. In region 3, there are also additional centralised wind resources, but since the problem for the decentralised scenario was the seasonal variation of continental winds, it will give a more stable system to exploit some of the centralised photovoltaic potential. For region 5, the only realistic proposal is to exploit substantial amounts of photovoltaic power, plus the smaller additional centralised biomass potential available. A little off-shore wind is exploitable in the South.

Table 11 gives the amounts of centralised sources proposed to be exploited in the centralised scenario, and Table 12 states the fraction of the potential resources that they constitute. For region 4 , we have reduced the use of biomass for fuels, in line with the arguments of forest preservation given in section 5.1. Still, region 4 has the option of a very large energy export.

The resulting energy system is much more robust than the decentralised one, and none of the renewable energy sources are utilised to the ceiling. This modesty should actually be considered realistic, due to the variations between seasons and years of renewable energy production (as already discussed for food production). Table 11 indicate substantial variations in supply/demand balances between seasons. We believe to have taken this into account by the storage cycle introduced (see Figures 74-80). However, a detailed simulation needs to be performed to ensure this, as done for Western Europe in a similar study (Sørensen, 1998). In an economic evaluation, the cost of establishing a surplus generation capacity is to be weighted against the cost of providing more energy storage than envisaged in our reference case $(50 \%$ of wind and solar cell power passing through storage facilities, as stated in section 4). It is in the spirit of the centralised scenario, that imports and exports are used in those cases where they ease the strain on ecosystems. It is therefore a conclusion, that the exploitation of centralised renewable resources allows more environmental concerns to be considered than insisting on producing as much as possible of the energy needed locally.

Table 11 gives the regional balances of supply and demand for the resources exploited in the centralised scenario (before import and export), and Figures 74-80 show the overall scenario and its regional implications. The food balances are identical to those of Figures 38-41, and the local surpluses and deficits for biofuels and electricity (before trade of energy) are shown in Figures 62-73. The main routes of import/export are depicted in Figure 81. The overall picture is similar to that of the decentralised scenario, except for the higher resilience obtained from the centralised production in wind farm, photovoltaic parks and energy forests or crops. The amount of centralised energy used to cover the scenario demand is still very modest compared to the potential listed in Chapter 4, even when it is used to ensure no abuse of new large hydro installations or rainforest conversion. The PV and wind energy export options arising e.g. for desert land give such areas new opportunities for development, and in some cases make up for current oil export revenues lost. Also the large biofuel exports considered for South America give credibility to the assumed substantial economic development of this continent. 
While it was not surprising that the decentralised scenario would have difficulties for the most densely populated regions, it may cause a little surprise to see how large a surplus of energy the centralised scenario offers. As discussed in the conclusions this has implications for other demand scenarios than the one discussed here. The surpluses are illustrated in Table 12 , which gives the percentages of estimated available resources actually used in the centralised scenario.

Table 11. Assumed energy supply (after storage conversion cycles and transmission but before interregional imports/exports) in centralised 2050 scenario, and corresponding supplydemand balances.

\begin{tabular}{|l|c|c|c|c|c|c|c|c|}
\hline Region (cf. Table 2) & $\mathbf{1}$ & $\mathbf{2}$ & $\mathbf{3}$ & $\mathbf{4}$ & $\mathbf{5}$ & $\mathbf{6}$ & Total & unit \\
\hline Total food balance (as Table 10) & 151 & 144 & 107 & 283 & -23 & -167 & $\mathbf{4 9 3}$ & $\mathrm{GW}$ \\
\hline Total biofuels used & 250 & 190 & 300 & 640 & 327 & 192 & $\mathbf{1 8 9 9}$ & $\mathrm{GW}$ \\
\hline Of which decentralised biofuels & 250 & 166 & 236 & 640 & 295 & 192 & $\mathbf{1 7 7 9}$ & $\mathrm{GW}$ \\
\hline $\begin{array}{l}\text { Balance: total biofueis minus } \\
\text { use for transportation }\end{array}$ & 136 & 158 & 146 & 277 & 392 & $\mathbf{6 1}$ & $\mathbf{1 1 7 0}$ & $\mathrm{GW}$ \\
\hline Hydro power & 80 & 70 & 50 & 120 & 110 & 10 & $\mathbf{4 4 0}$ & $\mathrm{GW}$ \\
\hline Decentralised solar power & 27 & 50 & 67 & 109 & 189 & 23 & $\mathbf{4 6 5}$ & $\mathrm{GW}$ \\
\hline Centralised solar power & 40 & 20 & 114 & 19 & 400 & 100 & $\mathbf{6 9 3}$ & $\mathrm{GW}$ \\
\hline Decentralised wind power & 20 & 37 & 80 & 100 & 100 & 10 & $\mathbf{3 4 7}$ & $\mathrm{GW}$ \\
\hline On-shore wind parks & 12 & 10 & 20 & 38 & 46 & 0 & $\mathbf{1 2 6}$ & $\mathrm{GW}$ \\
\hline Off-shore wind power & 0 & 40 & 0 & 0 & 13 & 0 & $\mathbf{5 3}$ & $\mathrm{GW}$ \\
\hline Balance: other energy, ann.av. & 100 & -63 & 139 & 288 & -660 & 217 & $\mathbf{2 2}$ & $\mathrm{GW}$ \\
\hline Balance: other energy, Jan. & 74 & -120 & 169 & 306 & $\mathbf{- 8 9 0}$ & 214 & $\mathbf{- 2 5 0}$ & $\mathrm{GW}$ \\
\hline Balance: other energy, April & 87 & -51 & 72 & 243 & -710 & 200 & $\mathbf{- 1 6 0}$ & $\mathrm{GW}$ \\
\hline Balance: other energy, July & 129 & -17 & 180 & 352 & -410 & 233 & $\mathbf{4 6 1}$ & $\mathrm{GW}$ \\
\hline Balance: other energy, Oct. & 110 & -64 & 129 & 252 & -610 & 220 & $\mathbf{3 5}$ & $\mathrm{GW}$ \\
\hline
\end{tabular}

Table 12. Fraction of potential resources used in centralised 2050 scenario.

\begin{tabular}{|l|c|c|c|c|c|c|c|}
\hline Region & $\mathbf{1}$ & $\mathbf{2}$ & $\mathbf{3}$ & $\mathbf{4}$ & $\mathbf{5}$ & $\mathbf{6}$ & Total \\
\hline Decentralised biofuels & 0.91 & 0.98 & 0.96 & 0.93 & 1.00 & 0.92 & 0.94 \\
\hline Centralised biofuels & 0 & 0.12 & 0.64 & 0 & 0 & 0 & 0.21 \\
\hline Hydro power & 0.88 & 0.82 & 0.95 & 0.48 & 0.90 & 0.67 & 0.71 \\
\hline Decentralised solar power & 0.54 & 0.93 & 0.71 & 0.76 & 0.99 & 0.20 & 0.72 \\
\hline Centralised solar power & 0.013 & 0.003 & 0.014 & 0.004 & 0.041 & 0.005 & 0.013 \\
\hline Decentralised wind power & 0.56 & 0.85 & 0.45 & 0.75 & 1.00 & 0.21 & 0.64 \\
\hline On-shore wind parks & 0.75 & 0.068 & 0.27 & 0.66 & 1.00 & 0 & 0.21 \\
\hline Off-shore wind power & 0 & 0.52 & 0 & 0 & 0.70 & 0 & 0.16 \\
\hline
\end{tabular}




\section{IMPLEMENTATION AND RESILIENCE OF SCENARIO}

In discussing the robustness of our scenarios against changes in assumptions, it is useful to separate the demand and the supply scenarios. The demand scenario assumes that efficiency measures are performed, that would entail smaller costs than any of the options for additional energy supply. This may appear a very reasonable assumption, but it is a feature of the present system, than in several demand categories, there are efficiency improvements not made, which would be highly economic even with current prices. The reason for this may be sought in the lower prestige seemingly accorded to demand-side measures as compared with new supply. If this element of irrationality can be eliminated in the future is uncertain, and many scenarios of future energy demand estimate substantially higher consumption levels than the one assumed in the present study. In our centralised 2050 scenario, there is a low utilisation of available renewable energy sources, and substantially higher demands could be satisfied, notably with photovoltaic plants not attached to buildings. The centralised scenario is thus highly resilient to changes in demand, whereas the tight matching of demand and supply in the decentralised scenario makes this more vulnerable.

With the supply scenarios, we found that the decentralised option, defined as using only building-integrated PV and less than one detached wind turbine per farm house, plus existing hydro, leaves little room for increase of supply. For buildings, a higher solar utilisation would require urban planning with orientation of streets and buildings optimised for solar capture. This is unlikely to be feasible, as half the buildings in 2050 already exists, and the other half will be built gradually over the 50 year period, implying the necessity of a very rapid action if urban planning aspects should be significantly altered. For farm-attached wind turbines, we have assumed that not every farm possesses a turbine by year 2050 . This is justified both due to resource variations (even on extended lands belonging to a farm, no site with suitable wind conditions may be found, due to nearby forests or other obstructing landscape features), and also because not all farmers may chose to install a turbine. The model we have adopted corresponds to the most dense dispersed wind turbine density found today in Denmark, and our assumption is that current smaller turbines will be replaced by larger ones by year 2050 . This is not even happening in Denmark, where the former regulation allowing replacement of turbines with few planning restriction has been replaced by a full planning review being required for each new installation, with the argument that the larger modern wind turbines pose new landscape integration problems. Thus it is also for wind turbines difficult to imagine a substantial increase within the decentralised mode, relative to the scenario proposed.

One area where the proposed decentralised scenario may be conservative, is in coverage of heat demands. There are a number of possibilities for deriving additional heat from the scenario, provided that district heating lines are available for transporting the heat to the sites of demand: The storage cycle, transforming wind and solar power to fuels and later regaining electricity through reversible fuel cells, gives rise to waste heat that could be lead to demand sites. The same is true of industrial high-temperature heat usage, where waste heat could be cascaded down to users of lower temperature heat. If these methods are adopted, the generation of low-temperature heat through heat pumps could be more or less eliminated, leaving more electricity to high quality uses. In practical terms, these options may allow a demand increase of some $25 \%$.

There are a few features of the "mechanised" scenario building that may be unrealistic: For instance in region 2, there is a high production of solar power in Australia, which could not in a practical way be transmitted to the demand sites in Japan and Europe. The same is true for off-shore wind power produced along the coasts of Greenland and Northern Norway. This affects only the centralised scenario, and since it has many unused, centralised renewable energy resources nearer to the demand centres, there is no serious problem involved. 
The centralised renewable energy scenario can easily remedy such local problems, and can sustain much higher levels of demand, while still offering seasonal smoothing of supply through the storage conversion cycles devised. As mentioned above, it also makes it much easier to solve the geographical mismatch between energy generation and demand. Due to the use of wind parks and central solar plants, it has less long-distance transport and transmission of energy than the decentralised scenario, but at the same time it readily accepts such energy trade, that may be considered incompatible with the value basis of a decentralised scenario.

Implementation of either of the 2050 scenarios involves sketching a path of moving from the current system primarily based on fossil fuels to a very different system, and identifying the conditions that have to be fulfilled to make the transition happen. These could be economic milestones for the new technologies involved, or they could be political decisions needed to be taken. We shall assume the social climate in which the transitions happen to be governed by the mixture of free market competition and regulations by society, as it is the case in most regions of the world today. The regulatory part would impose requirements, such as building codes and minimum technical standards for reasons of safety and consumer protection, and minimum energy use for appliances. Another public handle is environmental taxes, that incorporate indirect costs which otherwise would distort the competition between different solutions in the marketplace. A consistent method of estimating the environmental taxes that will make the market a fair one is life-cycle analysis of the entire energy supply chains and the technologies involved. The methodology for doing this, with examples for many of the renewable energy systems considered here, may be found in Kuemmel et al. (1997).

In a fair market, the price that new technologies have to measure up against, is the price of currently used coal, oil, natural gas, hydro and nuclear technologies, all supplemented with the externalities not included in the present market prices. Renewable technologies such as wind power, the cost of which today is only slightly above current fossil fuel-based systems, will clearly be economic if externalities are included (as these are very small for wind power and more than twice the actual price for fossil fuels). Also technologies such as biofuel production, which today involve a cost about twice that of fossil fuels, would in the fair market be able to enter by standard competitive forces. For photovoltaic power and the new conversion and storage technologies (e.g. fuel cells), present costs are higher than what can be remedied by introducing externalities in the comparison with fossil fuels. Therefore, these have to be assumed to pass through a technical development over the fifty year transition period, that brings the price down to below the threshold value. Subsidies may be contemplated in order to speed up this process in the initial phase, but already the political readiness to include externalities in prices would constitute a strong motivation for the development of alternative solutions.

The assumptions that the future transition will be driven by fair market rules are at variance with the present situation. On one side, there are hidden subsidies in some regions (e.g. to nuclear power), and on the other side, monopolies and generally differences in size and power of the industries involved in different technologies makes the price setting likely not to follow those prescribed by the life-cycle analysis in a fair market philosophy. An obvious solution is to regulate the market not by taxation but by legislation, requiring e.g. power providers to use specific technologies. This makes it unnecessary to accumulate tax money at the state level (which by some nations is seen as a positive feature), but makes the system rather stiff, as each technical change has to be followed up by possibly altering the legislative regime. The taxation method is more flexible, and once the level of environmental tax is decided by governments, the market functions exactly as before, but should give the manufacturers of the new technologies with smaller environmental impacts a good change to compete, even if they are initially smaller than the established market players. It is also important that externalities 
are set politically, thereby doing away with the uncertainties of scientific assessment, once the legislation is in place. A problem is the possible differences in tax levels, that different nations may see as fair. International synchronisation is highly desirable, as in all policy aimed at reducing global threats. Depending on the degree of planning tradition in different societies, the energy transition might also benefit from "setting goals" and continually monitoring if they are fulfilled. If for example the market does not respond well enough to the price signals set by the environmental taxes, it is then possible to adjust the size of the imposed externality (which would often not violate the scientific basis for it) or introduce specific legislation to remove the obstacles to a free and fair market.

A final remark may be in place regarding the use of the expression "centralised" to characterise the second scenario. By some, this expression has a negative value connotation, reminding of centralised economic planning or lack of decision power by the individual citizen. We use the word solely to signal the use of technologies that are not integrated into homes or controlled by individuals, as the rooftop solar panels, individually owned wind turbines and fuel cell plants located in each building in the decentralised scenario. We believe to have proven, that such community-size installations are beneficial for a robust energy system, regardless of the type of ownership structure that may be associated with them.

The work described above is based on an ongoing project on global energy alternatives performed for the Danish Energy Agency under its Energy Research Programme EFP-96, looking in addition to the two renewable energy scenarios at a carbon dioxide controlling fossil scenario and an advanced nuclear technology "safe nuclear" scenario. 


\section{REFERENCES}

Alexandratos, N., 1995. World agriculture: Towards 2010. An FAO study. Wiley \& Sons, Chichester

Anderson, J., Hardy, E., Roach, J. and Witmer, R., 1976. A land use and land cover classification system for use with remore sensor data. US Geological Survey Professional Paper \# 964, 28pp. Data available at website http://edcwww.cr.usgs.gov/landdaac/glcc/

CIESIN, 1997. Gridded population of the world. David Simonett Center for Space Studies at University of Santa Barbara, California, NCGIA Technical Report TR-95-6; Consortium for Int. Earth Science Information Network website: http://www.ciesin.org/datasets/gpw/globdem.doc.html

Danish Technology Council, 1996. Light-green agriculture, proceedings of a consensus conference held at the Danish Parliament. Report 1994/5 (in Danish). Available at website http://www.tekno.dk/udgiv/udgdata.htm

Evenden, G., 1997. General cartographic projection package version 4.3.2, US Geological Survey at Woods Hole, available from website http://kai.er.usgs.gov/intro/mapgendetails.html

IPCC, 1996. Climate Change 1995: Impacts, adaptation and mitigation of climate change: Scientific-technical analysis. Contribution of WGII (Watson et al., eds.), Cambridge University Press, $572 \mathrm{pp}$.

IPCC Data Distribution Centre, 1998. Website http://www.dkrz.de/ipcc/ddc/html/gfdlrun2.html

Jensen, J. and Sørensen, B., 1984. Fundamentals of energy storage. 345 pp. Wiley, New York

Kalney, E. et al., 1996. The NCEP/NCAR 40-year reanalysis project. Bulletin of the American Meteorological Society; data available at website http://ingrid.ldgo.columbia.edu/sources/ in the catalogue of NOAA NCEP-NCAR CDAS-1 data sets.

Kuemmel, B., Nielsen, S. and Sørensen, B., 1997. Life-cycle analysis of energy systems. Roskilde University Press, Copenhagen. $216 \mathrm{pp}$. Website http://mmf.ruc.dk/energy

Leemans, R. and Cramer, W., 1998. IMAGE2 Climate database, available at the website http://www.pik-potsdam.de/public/climate

MAPINFO, 1997. Mapinfo Professional v4.5, GIS software, Troy, State of New York.

Melillo, J. and Helfrich, J., 1998; NPP database created under NASA and EPRI grants, kindly put at our disposal.

Melillo, J., McGuire, A., Kicklighter, D., Moore-III, B., Vorosmarty, C. and Schloss, A., 1993. Global climate change and terrestrial net primary production. Nature, vol. 363, pp. 234-240

McGuire. A., Melillo, J., Kicklighter, D., Pan, Y., Xiao, X., Helfrich, J., Moore-III, B., Vorosmarty, C. and Schloss, A., 1997. Equilibrium responses of global net primary production and carbon storage to doubled atmospheric carbon dioxide: sensitivity to changes in vegetation nitrogen concentrations. Global Biogeochem. Cycles, vol. 11, pp. 173-189

Mitchell, J. and Johns, T., 1997. On modification of global warming by sulphate aerosols, Journal of Climate, vol. 10, pp. 245-267. Model output (12 months by 240 years) available at IPCC Data Distribution (1998) website http://www.dkrz.de/ipcc/ddc/html/gfdlrun2.html

NASA, 1997. Surface solar energy data set v1.0, available from NASA Langley Research Center EOSDIS Distributed Active Archive Center at website http://eosweb.larc.nasa.gov/

Naturlig Energi, 1998. Wind power production statistics, pp. 14-17, June issue (in Danish).

NCEP/NCAR, 1998. 40-year reanalysis project. Bulletin of the American Meteorological Society; data available at the website http://ingrid.ldgo.columbia.edu/sources/ in the catalogue of NOAA NCEP-NCAR CDAS-1 data sets. 
Nielsen, S. and Sørensen, B., 1996. Long-term planning for energy efficiency and renewable energy. Paper presented at "Renewable Energy Conference, Cairo April 1996" and revised for inclusion in this issue of International Journal of Global Energy Issues.

Nielsen, S. and Sørensen, B., 1998. A fair-market scenario of the European energy system. Chapter 3 (pp. 127-186) in "Long-term integration of renewable energy sources into the European energy system" (The LTI-Research Group, ed.), European Commission / Physica Verlag, Bonn.

OECD, 1996. Energy balances of OECD countries 1993-4. Energy statistics of OECD countries 1993-4, Energy statistics of non-OECD countries 1993-4. Paris

Pacific Solar, 1997. Annual Company Review, Sydney (20pp).

Petersen, H. and Lundsager, P., 1998. Comparison of wind turbines based on power curve analysis. Report for the Danish Energy Agency, HP Consult and Darup Associates Ltd.

Pinker, R. and Laszlo, I., 1992. Modelling surface solar irradiance for satellite applications on a global scale. J. Applied Meteorology, vol. 31, pp. 194-211

Raich, J., Rastetter, E., Melillo, J., Kicklighter, D., Steudler, P., Peterson, B., Grace, A., Moore-III, B. and Vörösmarty, C., 1991. Potential net primary productivity in South America: application of a global model. Ecological Applic., vol. 1, pp. 399-429.

Sandwell, D., Smith, W., Smith, S. and Small, C., 1998. Measured and estimated seafloor topography. Available together with land topography at the website http://ingrid.ldgo.columbia.edu/sources/

Sellers, P., Dickinson, R., Randall, D., Betts, A., Hall., F., Berry, J., Collatz, G., Denning., Mooney, H., Nobre, C., Sato, N., Field, C. and Henderson-Sellers, A., 1997. Modelling the exchanges of energy, water, and carbon between continents and the atmosphere. Science, vol. 275, pp. 502-509

Smith, W. and Sandwell, D., 1997. Global sea floor topography from satellite altimetry and ship depth sounding, Science, vol. 277, pp. 1956-1962

Sørensen, B., 1979. Renewable Energy. 687 pp. Academic Press, London and New York

Sørensen, B., 1995. History of, and recent progress in, wind-energy utilization. Annual Review of Energy \& Environment, vol. 20, pp. 387-424

Sørensen, B., 1995b. Strategy for a rich, fulfilling and sustainable society. In "Expanding environmental perspectives" (Lundgren, Nilsson and Schlyter, eds.), pp. 83-101. Lund University Press

Sørensen, B., 1996. Scenarios for greenhouse warming mitigation. Energy Conversion and Management, vol. 37 , pp. 693-698

Sørensen, B., 1997. Impacts of energy use, pp. 243-266 in "Human ecology, human economy" (Diesendorf and Hamilton, eds.), Allen and Unwin, New South Wales

Sørensen, B., 1998. Non-linear Modelling of integrated energy supply and demand matching systems. Int. Journal of Global Energy Issue (forthcoming).

Sørensen, B., Nielsen, L., Petersen, S., Illum, K. and Morthorst, P., 1994. Future renewable energy system - light green or dark green? Danish Technology Council, Report 1994/3 (in Danish), available at website http://www.tekno.dk/udgiv/943/943all.htm

Swisher, R., 1995. Wind power a strong contender in US energy marketplace, pp. 190-196 in "The world directory of renewable energy suppliers and services", James \& James, London

Tobler, W., Deichmann, U., Gottsegen, J. and Maloy, K., 1995. The global demography project. National Center for Geographic Information and Analysis, University of California at St. Barbara, Technical Report TR-95-6

Troen, I and Petersen, E., 1989. European Wind Atlas. Risø National Laboratory, Roskilde UN, 1996. Populations 1996, 2015, 2050. United Nations Population Division and UNDP: 
http://www.undp.org/popin/wdtrends/pop/fpop.htm

UN, 1997. UN urban and rural population estimates and projections as revised in 1994. United Nations Population Division and UNDP, Washington. Data available from website: http://www.undp.org/popin/wdtrends/urban.html

US Defence Mapping Agency, 1992. Development of the Digital Chart of the World. US Government Printing Office, Washington DC.

US Geological Survey, 1997. Global land cover characteristics data base version 1.2, a collaboration with Earth Resources Observation System Data Center, University of Nebraska at Lincoln, and the Joint Researach Centre of the European Commission; available at website http://edcwww.cr.usgs.gov/landdaac/glcc/ or ftp://edcftp.cr.usgs.gov/pub/data/glcc

Vitousek, P., Mooney, H., Lubchenko, J. and Melillo, J., 1997. Human domination of Earth's ecosystem, Science, vol. 277, pp. 494-499

Waggoner, P., 1994. How much land can ten billion people spare for nature. Council for Agricultural Science and Technology, Task force Report \# 121.

World Energy Council, 1995. Survey of energy rsources, 17. Ed., London

World Resources Institute, 1996. World Resources 1996-97. Oxford University Press, Oxford; website http://www.wri.org/wri/wr-96-97/ 
APPENDIX A: REGIONAL ASSIGNMENTS OF COUNTRIES

\begin{tabular}{|c|c|c|c|c|c|c|}
\hline COUNTRY & CONTINENT & $\begin{array}{l}\text { RE- } \\
\text { GION }\end{array}$ & \begin{tabular}{|c|} 
POPULATION \\
1996 \\
\end{tabular} & $\begin{array}{c}\text { POPULATION } \\
2050\end{array}$ & $\begin{array}{c}\text { Urban \% } \\
1992 \\
\end{array}$ & $\begin{array}{c}\text { Urban \% } \\
2050 \\
\end{array}$ \\
\hline Afghanistan & Asia & III & 20883 & 61373 & 18.92 & 55.97 \\
\hline Albania & Europe & II & 3401 & 4747 & 36.34 & 72.65 \\
\hline Algeria & Africa & VI & 28784 & 58991 & 53.34 & 89.65 \\
\hline Andorra & Europe & II & & & & \\
\hline Angola & Africa & VI & 11185 & 38897 & 29.86 & 75.80 \\
\hline Anguilla & North America & IV & 8 & 13 & 0.00 & 0.00 \\
\hline Antarctica & Antarctica & - & & & & \\
\hline Antigua \& Barbuda & North America & IV & 66 & 99 & 35.56 & 60.94 \\
\hline Argentina & South America & IV & 35219 & 54522 & 87.14 & 90.00 \\
\hline Armenia & \begin{tabular}{|l} 
Europe \\
\end{tabular} & II & 3638 & 4376 & 67.98 & 89.11 \\
\hline Aruba (Netherlands) & North America & IV & 71 & 109 & 0.00 & 0.00 \\
\hline Australia & Australia & II & 18057 & 25286 & 84.94 & 90.00 \\
\hline Austria & \begin{tabular}{|l} 
Europe \\
\end{tabular} & II & 8106 & 7430 & 55.44 & 77.52 \\
\hline Azerbaijan & Europe & II & 7594 & 10881 & 54.96 & 83.15 \\
\hline Azores (Portuguese) & \begin{tabular}{|l} 
Europe \\
\end{tabular} & II & & & & \\
\hline Bahamas & North America & $\mathrm{I}$ & 284 & 435 & 84.76 & 85.18 \\
\hline Bahrain & Asia & III & 570 & 940 & 88.62 & 90.00 \\
\hline Bangladesh & Asia & III & 120073 & 218188 & 16.74 & 57.62 \\
\hline Barbados & \begin{tabular}{|l} 
North America \\
\end{tabular} & IV & 261 & 306 & 45.84 & 53.15 \\
\hline Belarus & Europe & III & 10348 & 8726 & 68.56 & 90.00 \\
\hline Belgium & \begin{tabular}{|l} 
Europe \\
\end{tabular} & II & 10159 & 9763 & 96.70 & 90.00 \\
\hline Belize & North America & IV & 219 & 480 & 47.28 & 69.64 \\
\hline Benin & Africa & $\mathrm{VI}$ & 5563 & 18095 & 29.92 & 68.73 \\
\hline Bermuda & North America & IV & & & & \\
\hline Bhutan & Asia & III & 1812 & 5184 & 6.00 & 28.85 \\
\hline Bolivia & South America & IV & 7593 & 16966 & 57.80 & 90.00 \\
\hline Bosnia and Herzegovina & Europe & II & 3628 & 3789 & 49.00 & 84.15 \\
\hline Botswana & \begin{tabular}{|l|} 
Africa \\
\end{tabular} & VI & 1484 & 3320 & 25.10 & 77.65 \\
\hline Brazil & South America & IV & 161087 & 243259 & 72.04 & 90.00 \\
\hline British Virgin Islands & North America & $\mathrm{I}$ & 19 & 37 & 0.00 & 0.00 \\
\hline Brunei Darussalam & Asia & III & 300 & 512 & 57.74 & 79.29 \\
\hline Bulgaria & Europe & II & 8468 & 6690 & 68.90 & 90.00 \\
\hline Burkina Faso & Africa & $\mathrm{VI}$ & 10780 & 35419 & 21.62 & 90.00 \\
\hline Burundi & \begin{tabular}{|l|} 
Africa \\
\end{tabular} & VI & 6221 & 16937 & 6.78 & 31.77 \\
\hline Cambodia & Asia & $\mathrm{V}$ & 10273 & 21394 & 18.84 & 63.06 \\
\hline Cameroon & Africa & VI & 13560 & 41951 & 42.14 & 85.83 \\
\hline Canada & North America & I & 29680 & 36352 & 76.64 & 89.58 \\
\hline Cape Verde & \begin{tabular}{|l|} 
Africa \\
\end{tabular} & $\mathrm{VI}$ & 396 & 864 & 48.24 & 68.91 \\
\hline Cayman Islands & North America & IV & 32 & 67 & 100.00 & 100.00 \\
\hline Central African Republic & Africa & $\mathrm{VI}$ & 3344 & 8215 & 39.00 & 74.15 \\
\hline Chad & Africa & $\mathrm{VI}$ & 6515 & 18004 & 20.86 & 52.74 \\
\hline Chile & South America & IV & 14421 & 22215 & 83.54 & 90.00 \\
\hline China & Asia & $\mathrm{V}$ & 1232083 & 1516664 & 27.84 & 75.58 \\
\hline Colombia & South America & IV & 36444 & 62284 & 71.08 & 90.00 \\
\hline Comoros & Africa & VI & 632 & 1876 & 28.96 & 48.36 \\
\hline Congo & Africa & VI & 2668 & 8729 & 55.62 & 90.00 \\
\hline Cook Islands & Oceania & IV & 19 & 29 & 0.00 & 0.00 \\
\hline Costa Rica & North America & IV & 3500 & 6902 & 48.14 & 84.80 \\
\hline Croatia & Europe & III & 4501 & 3991 & 61.64 & 90.00 \\
\hline Cuba & North America & IV & 11018 & 11284 & 74.56 & 90.00 \\
\hline
\end{tabular}




\begin{tabular}{|c|c|c|c|c|c|c|}
\hline Cyprus & Europe & III & 756 & 1029 & 52.48 & 65.70 \\
\hline Czech Republic & Europe & III & 10251 & 8572 & 65.10 & 84.26 \\
\hline Denmark & Europe & II & 5237 & 5234 & 84.96 & 90.00 \\
\hline Djibouti & Africa & VI & 617 & 1506 & 81.54 & 90.00 \\
\hline Dominica & North America & IV & 71 & 97 & 0.00 & 0.00 \\
\hline Dominican Republic & North America & IV & 7961 & 13141 & 62.08 & 90.00 \\
\hline Ecuador & South America & IV & 11699 & 21190 & 56.24 & 90.00 \\
\hline Egypt & Africa & VI & 63271 & 115480 & 44.26 & 75.44 \\
\hline El Salvador & North America & IV & 5796 & 11364 & 44.38 & 75.35 \\
\hline Equatorial Guinea & Africa & VI & 410 & 1144 & 38.30 & 90.00 \\
\hline Eritrea & Africa & VI & 3280 & 8808 & 17.00 & 50.39 \\
\hline Estonia & Europe & III & 1471 & 1084 & 72.32 & 90.00 \\
\hline Ethiopia & Africa & VI & 58243 & 212732 & 12.74 & 43.08 \\
\hline Falkland Islands & South America & IV & & & & \\
\hline Fiji & Oceania & IV & 797 & 1393 & 39.86 & 75.26 \\
\hline Finland & Europe & II & 5126 & 5172 & 62.12 & 86.52 \\
\hline Fmr. Yugosl. Rep. Macedonia & Europe & III & 2174 & 2646 & 58.64 & 85.64 \\
\hline France & Europe & II & 58333 & 58370 & 72.74 & 89.02 \\
\hline French Guiana & South America & IV & 153 & 353 & 75.36 & 83.52 \\
\hline French Polynesia & Oceania & IV & 223 & 403 & 56.40 & 80.30 \\
\hline Gabon & Africa & VI & 1106 & 2952 & 47.42 & 87.11 \\
\hline Gambia & Africa & VI & 1141 & 2604 & 23.76 & 68.12 \\
\hline Georgia & Asia & III & 5442 & 6028 & 57.00 & 86.88 \\
\hline Germany & Europe & II & 81922 & 69542 & 85.78 & 90.00 \\
\hline Ghana & Africa & VI & 17832 & 51205 & 34.92 & 75.48 \\
\hline Gibraltar & Europe & II & 28 & 28 & 100.00 & 100.00 \\
\hline Greece & Europe & II & 10490 & 9013 & 63.64 & 90.00 \\
\hline Greenland & Europe & II & 58 & 72 & 78.90 & 86.11 \\
\hline Grenada & North America & IV & 92 & 134 & 0.00 & 0.00 \\
\hline Guadeloupe & North America & IV & 431 & 634 & 98.86 & 90.00 \\
\hline Guam & Oceania & IV & 153 & 250 & 38.08 & 59.03 \\
\hline Guatemala & North America & IV & 10928 & 29353 & 40.24 & 78.48 \\
\hline Guinea & Africa & $\mathrm{VI}$ & 7518 & 22914 & 27.32 & 72.45 \\
\hline Guinea Bissau & Africa & $\overline{V I}$ & 1091 & 2674 & 20.82 & 63.32 \\
\hline Guyana & South America & IV & 838 & 1239 & 34.64 & 77.45 \\
\hline Haiti & North America & IV & 7259 & 17524 & 29.80 & 72.33 \\
\hline Honduras & North America & IV & 5816 & 13920 & 41.98 & 80.68 \\
\hline Hong Kong & Asia & IV & & & & \\
\hline Hungary & Europe & III & 10049 & 7715 & 63.14 & 90.00 \\
\hline Iceland & Europe & II & 271 & 363 & 91.00 & 90.00 \\
\hline India & Asia & $\mathrm{V}$ & 944580 & 1532674 & 26.02 & 59.38 \\
\hline Indonesia & Asia & IV & 200453 & 318264 & 32.52 & 82.58 \\
\hline Iran & Asia & $\mathrm{V}$ & 69975 & 170269 & 57.38 & 88.35 \\
\hline Iraq & Asia & $\mathrm{V}$ & 20607 & 56129 & 72.92 & 90.00 \\
\hline Iraq-Saudi Arabia Neutral Zone & Asia & $\mathrm{V}$ & & & & \\
\hline Ireland & Europe & II & 3554 & 3809 & 57.14 & 81.50 \\
\hline Israel & Asia & III & 5664 & 9144 & 90.42 & 90.00 \\
\hline Italy & Europe & II & 57226 & 42092 & 66.66 & 83.08 \\
\hline Ivory Coast & Africa & VI & 14015 & 31706 & 41.68 & 80.91 \\
\hline Jamaica & North America & IV & 2491 & 3886 & 52.38 & 83.35 \\
\hline Japan & Asia & II & 125351 & 109546 & 77.36 & 90.00 \\
\hline Jordan & Asia & III & 5581 & 16671 & 69.40 & 90.00 \\
\hline Kazakhstan & Asia & III & 16820 & 22260 & 58.44 & 87.55 \\
\hline Kenya & Africa & VI & 27799 & 66054 & 25.24 & 70.52 \\
\hline Kiribati & Oceania & IV & 80 & 165 & 35.04 & 61.33 \\
\hline
\end{tabular}




\begin{tabular}{|c|c|c|c|c|c|c|}
\hline Korea Dem. People's Rep. & Asia & $\mathrm{V}$ & 22466 & 32873 & 60.40 & 86.06 \\
\hline Korea & 8.6 & Asia & 45314 & 52146 & 76.80 & 90.00 \\
\hline Kuwait & Asia & III & 1687 & 3406 & 96.34 & 90.00 \\
\hline Kyrgyzstan & Asia & III & 4469 & 7182 & 38.48 & 71.03 \\
\hline Laos & Asia & $\mathrm{V}$ & 5035 & 13889 & 22.00 & 62.42 \\
\hline Latvia & Europe & III & 2504 & 1891 & 71.84 & 90.00 \\
\hline Lebanon & Asia & III & 3084 & 5189 & 85.16 & 90.00 \\
\hline Lesotho & Africa & VI & 2078 & 5643 & 20.88 & 66.79 \\
\hline Liberia & Africa & $\mathrm{VI}$ & 2245 & 9955 & 43.26 & 81.47 \\
\hline Libya Arab Jamahiriy & Africa & VI & 5593 & 19109 & 83.84 & 90.00 \\
\hline Liechtenstein & Europe & II & & & & \\
\hline Lithuania & Europe & III & 3728 & 3297 & 70.12 & 90.00 \\
\hline Luxembourg & Europe & II & 412 & 461 & 87.42 & 90.00 \\
\hline Madagascar & Africa & VI & 15353 & 50807 & 25.12 & 68.85 \\
\hline Malawi & Africa & VI & 9845 & 29825 & 12.48 & 46.79 \\
\hline Malaysia & Asia & IV & 20581 & 38089 & 51.36 & 89.39 \\
\hline Maldives & Asia & $\mathrm{V}$ & & & & \\
\hline Mali & Africa & VI & 11134 & 36817 & 25.08 & 68.88 \\
\hline Malta & Europe & II & 369 & 442 & 88.28 & 90.00 \\
\hline Marshall Islands & Oceania & IV & & & & \\
\hline Martinique & North America & IV & 384 & 518 & 91.62 & 90.00 \\
\hline Mauritania & Africa & $\mathrm{VI}$ & 2333 & 6077 & 49.60 & 90.00 \\
\hline Mauritius & Africa & VI & 1129 & 1654 & 40.54 & 71.23 \\
\hline Mexico & North America & IV & 92718 & 154120 & 73.68 & 90.00 \\
\hline Micronesia & Oceania & IV & 126 & 342 & 27.04 & 49.82 \\
\hline Moldova & Europe & III & 4444 & 5138 & 49.36 & 87.39 \\
\hline Monaco & Europe & II & & & & \\
\hline Mongolia & Asia & $\mathrm{V}$ & 2515 & 4986 & 59.16 & 88.76 \\
\hline Morocco & Africa & VI & 27021 & 47276 & 47.02 & 80.38 \\
\hline Mozambique & Africa & $\mathrm{VI}$ & 17796 & 51774 & 29.76 & 84.67 \\
\hline Myanmar & Asia & $\mathrm{V}$ & 45922 & 80896 & 25.36 & 63.39 \\
\hline Namibia & Africa & $\mathrm{VI}$ & 1575 & 4167 & 34.10 & 86.65 \\
\hline Nauru & Oceania & IV & 11 & 25 & 0.00 & 0.00 \\
\hline Nepal & Asia & $\mathrm{V}$ & 22021 & 53621 & 12.02 & 50.65 \\
\hline Netherlands & Europe & II & 15575 & 14956 & 88.82 & 90.00 \\
\hline New Caledonia & Oceania & IV & 184 & 295 & 60.78 & 76.98 \\
\hline New Zealand & Australia & II & 3602 & 5271 & 85.32 & 90.00 \\
\hline Nicaragua & North America & IV & 4238 & 9922 & 61.04 & 90.00 \\
\hline Niger & Africa & $\overline{\mathrm{VI}}$ & 9465 & 34576 & 15.92 & 51.21 \\
\hline Nigeria & Africa & VI & 115020 & 338510 & 36.84 & 81.06 \\
\hline Niue & Oceania & IV & 2 & 2 & 0.00 & 0.00 \\
\hline Northern Mariana Islands & Oceania & IV & 49 & 92 & 0.00 & 0.00 \\
\hline Norway & Europe & II & 4348 & 4694 & 72.66 & 89.08 \\
\hline Oman & Asia & III & 2302 & 10930 & 11.88 & 49.00 \\
\hline Pakistan & Asia & $\mathrm{V}$ & 139973 & 357353 & 33.08 & 75.12 \\
\hline Palau Islands & Oceania & IV & 17 & 35 & 0.00 & 0.00 \\
\hline Panama & North America & IV & 2677 & 4365 & 52.34 & 83.38 \\
\hline Panama Canal Zone & & IV & & & & \\
\hline Papua New Guinea & Asia & $\mathrm{V}$ & 4400 & 9637 & 15.40 & 44.58 \\
\hline Paraguay & South America & IV & 4957 & 12565 & 50.42 & 88.35 \\
\hline Peru & South America & IV & 23944 & 42292 & 70.76 & 90.00 \\
\hline Philippines & Asia & IV & 69282 & 130511 & 50.96 & 90.00 \\
\hline Poland & Europe & III & 38601 & 39725 & 63.38 & 89.08 \\
\hline Portugal & Europe & II & 9808 & 8701 & 34.34 & 70.65 \\
\hline Puerto Rico & North America & IV & 3736 & 5119 & 72.14 & 77.17 \\
\hline
\end{tabular}




\begin{tabular}{|c|c|c|c|c|c|c|}
\hline Qatar & Asia & III & 558 & 861 & 90.50 & 90.00 \\
\hline Reunion & Africa & VI & 664 & 1033 & 65.46 & 82.23 \\
\hline Romania & Europe & III & 22655 & 19009 & 54.14 & 83.77 \\
\hline Russian Federation & Asia & III & 148126 & 114318 & 74.80 & 90.00 \\
\hline Rwanda & Africa & VI & 5397 & 16937 & 5.80 & 21.97 \\
\hline Saint Lucia & North America & IV & 144 & 235 & 46.84 & 52.39 \\
\hline San Marino & Europe & II & & & & \\
\hline Sao Tome \& Principe & Africa & VI & 135 & 294 & 0.00 & 0.00 \\
\hline Saudi Arabia & Asia & III & 18836 & 59812 & 78.46 & 90.00 \\
\hline Senegal & Africa & $\mathrm{VI}$ & 8532 & 23442 & 40.80 & 78.06 \\
\hline Seychelles & Africa & VI & 74 & 106 & 51.68 & 75.09 \\
\hline Sierra Leone & Africa & VI & 4297 & 11368 & 33.80 & 78.09 \\
\hline Singapore & Asia & IV & 3384 & 4190 & 100.00 & 100.00 \\
\hline Slovakia & Europe & II & 5347 & 5260 & 57.42 & 86.56 \\
\hline Slovenia & Europe & III & 1924 & 1471 & 60.80 & 90.00 \\
\hline Solomon Islands & Oceania & IV & 391 & 1192 & 15.60 & 40.91 \\
\hline Somalia & Africa & VI & 9822 & 36408 & 24.80 & 62.06 \\
\hline South Africa & Africa & VI & 42393 & 91466 & 49.84 & 83.52 \\
\hline Spain & Europe & II & 39674 & 31755 & 75.84 & 90.00 \\
\hline Sri Lanka & Asia & $\mathrm{V}$ & 18100 & 26995 & 21.80 & 59.06 \\
\hline St.Kitts \& Nevis & North America & IV & 41 & 56 & 40.72 & 57.03 \\
\hline St.Vincent \& Grenadine & North America & IV & 113 & 174 & 0.00 & 0.00 \\
\hline Sudan & Africa & VI & 27291 & 59947 & 23.34 & 63.17 \\
\hline Suriname & South America & IV & 432 & 711 & 48.66 & 86.17 \\
\hline Swaziland & Africa & VI & 881 & 2228 & 28.32 & 78.73 \\
\hline Sweden & Europe & II & 8819 & 9574 & 83.10 & 90.00 \\
\hline Switzerland & Europe & II & 7224 & 6935 & 60.02 & 84.59 \\
\hline Syrian Arab Rep. & Asia & III & 14574 & 34463 & 51.08 & 84.33 \\
\hline Taiwan & Asia & IV & 2087 & 2583.706 & 0.00 & 0.00 \\
\hline Tajikistan & Asia & III & 5935 & 12366 & 32.20 & 63.48 \\
\hline Tanzania & Africa & VI & 30799 & 88963 & 22.24 & 67.52 \\
\hline Thailand & Asia & IV & 58703 & 72969 & 19.22 & 53.98 \\
\hline Togo & Africa & VI & 4201 & 12655 & 29.42 & 69.11 \\
\hline Tonga & Oceania & IV & 98 & 128 & 37.50 & 59.47 \\
\hline Trinidad \& Tobago & South America & IV & 1297 & 1899 & 70.18 & 90.00 \\
\hline Tunisia & Africa & $\mathrm{VI}$ & 9156 & 15907 & 55.82 & 87.77 \\
\hline Turkey & Europe & III & 61797 & 97911 & 64.06 & 90.00 \\
\hline Turkmenistan & Asia & III & 4155 & 7916 & 44.90 & 73.20 \\
\hline Turks And Caicos Islands & North America & IV & 15 & 32 & 0.00 & 0.00 \\
\hline Tuvalu & Oceania & IV & & & & \\
\hline US Virgin Islands & North America & 1 & 106 & 158 & 0.00 & 0.00 \\
\hline Uganda & Africa & $\mathrm{VI}$ & 20256 & 66305 & 11.72 & 42.09 \\
\hline Ukraine & Europe & III & 51608 & 40802 & 68.62 & 90.00 \\
\hline United Arab Emirates & Asia & III & 2260 & 3668 & 82.20 & 90.00 \\
\hline United Kingdom & Europe & II & 58144 & 58733 & 89.26 & 90.00 \\
\hline United States & North America & $\mathrm{I}$ & 269444 & 347543 & 75.60 & 90.00 \\
\hline Uruguay & \begin{tabular}{|l} 
South America \\
\end{tabular} & IV & 3204 & 4027 & 89.46 & 90.00 \\
\hline Uzbekistan & Asia & III & 23209 & 45094 & 40.88 & 72.73 \\
\hline Vanuatu & Oceania & IV & 174 & 456 & 18.82 & 38.47 \\
\hline Vatican City (Holy See) & \begin{tabular}{|l|} 
Europe \\
\end{tabular} & II & & & & \\
\hline Venezuela & South America & IV & 22311 & 42152 & 91.36 & 90.00 \\
\hline Vietnam & Asia & $\mathrm{V}$ & 75181 & 129763 & 20.26 & 53.20 \\
\hline Western Sahara & Africa & VI & 256 & 558 & 41.00 & 56.82 \\
\hline Western Samoa & Oceania & IV & 166 & 319 & 57.86 & 79.20 \\
\hline Yemen & Asia & III & 15678 & 61129 & 30.78 & 78.62 \\
\hline
\end{tabular}




\begin{tabular}{|l|l|l|r|r|r|r|}
\hline Yugoslavia (Serbia, Montenegro) & Europe & III & 10294 & 10979 & 54.46 & 88.80 \\
\hline Zaire & Africa & VI & 46812 & 164635 & 28.50 & 66.29 \\
\hline Zambia & Africa & VI & 8275 & 21965 & 42.04 & 73.61 \\
\hline Zimbabwe & Africa & VI & 11439 & 24904 & 32.00 & 72.42 \\
\hline
\end{tabular}

The selection of countries/territories and their names is based on the definitions of borders used in common GIS softwaere (MAPINFO, 1997), population data are from UN (1996) and urbanisation percentages from UN (1997). 


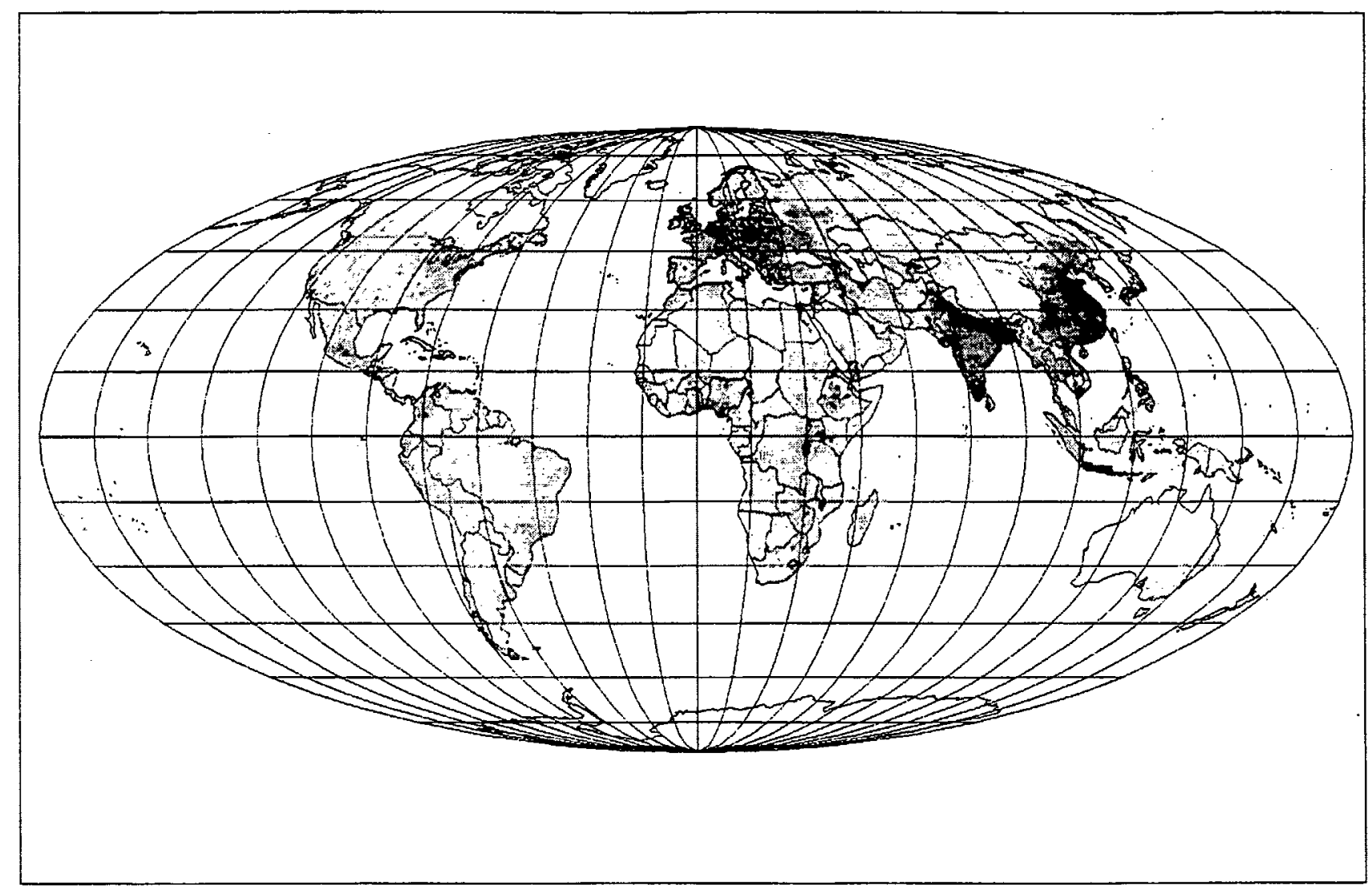

Figure 1a: Present population density: 1994 data (source: CIESIN, 1997; scale given in Figure 1b). This and all following geographical maps are employing the Mollweide equal area projection, consistent with our rendering of area-based densities of various quantities. This means that visual summing up over or comparison between different regions will be correct, in contrast to the situation for e.g. longitude-latitude square grids.

Figure 1b: Population scale (people per $\mathrm{km}^{2}$, note that the scale is not linear)

Population density
cap/km2
3000 to 6000
1500 to 3000
800 to 1500
550 to 800
380 to 550
250 to 380
150 to 250
80 to 150
40 to 80
20 to 40
10 to 20
0.1 to 10
all others




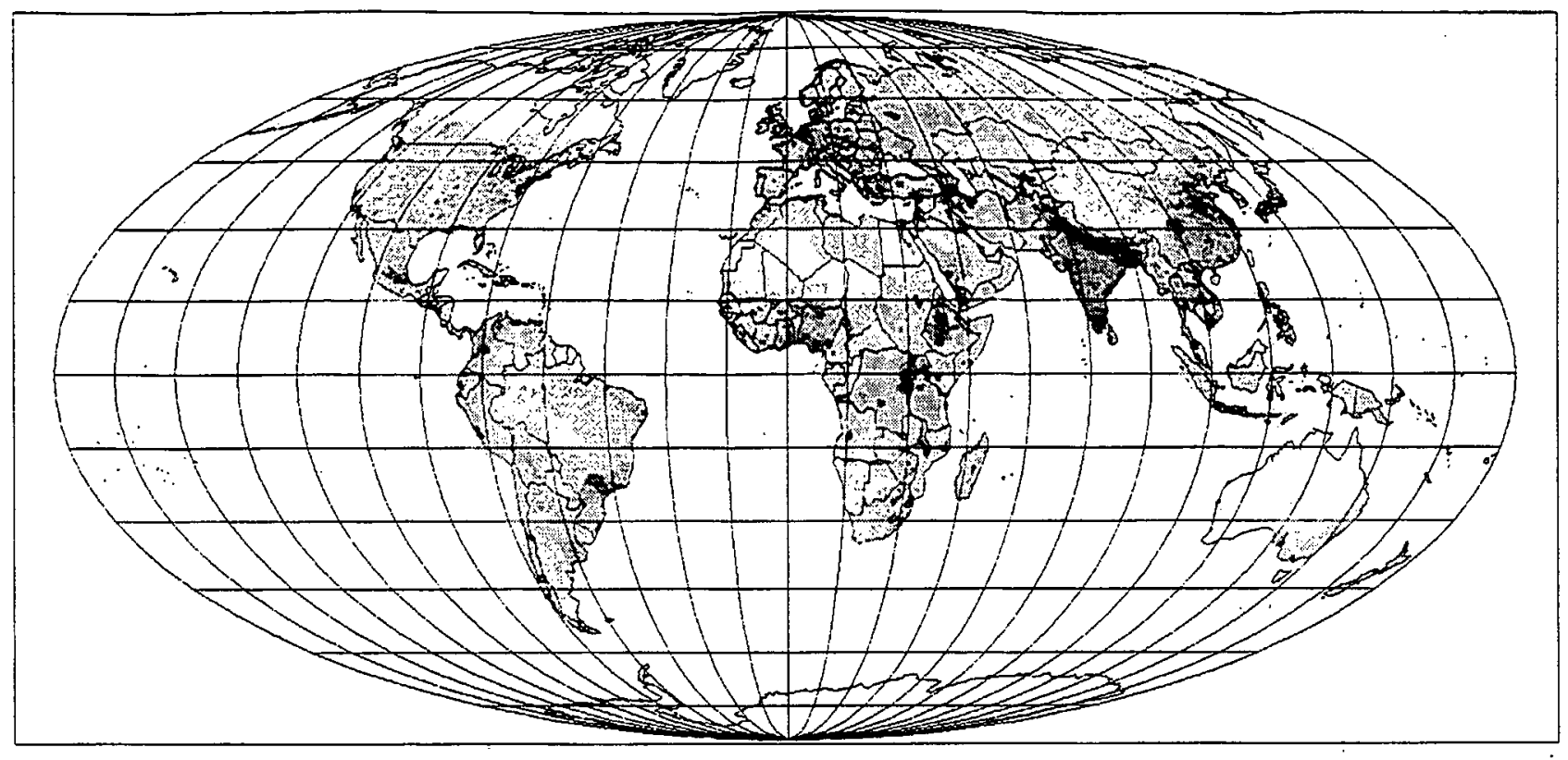

Figure 2. Population density assumed in 2050 (scale given in Figure 1b).

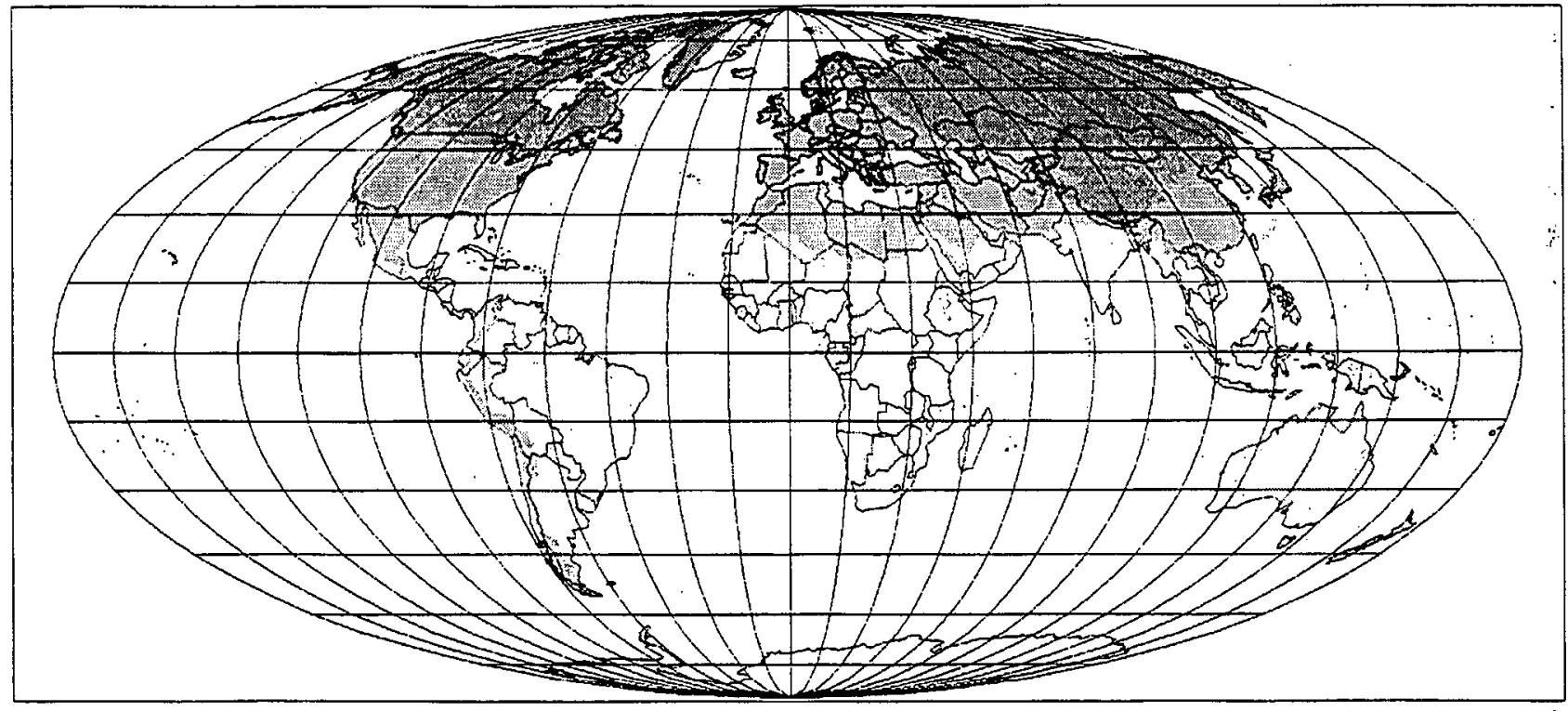

Figure 3a. January average temperatures indicating areas with space heating and cooling needs (source: Leemans and Cramer, 1998; the scale is given in Figure 3e). 


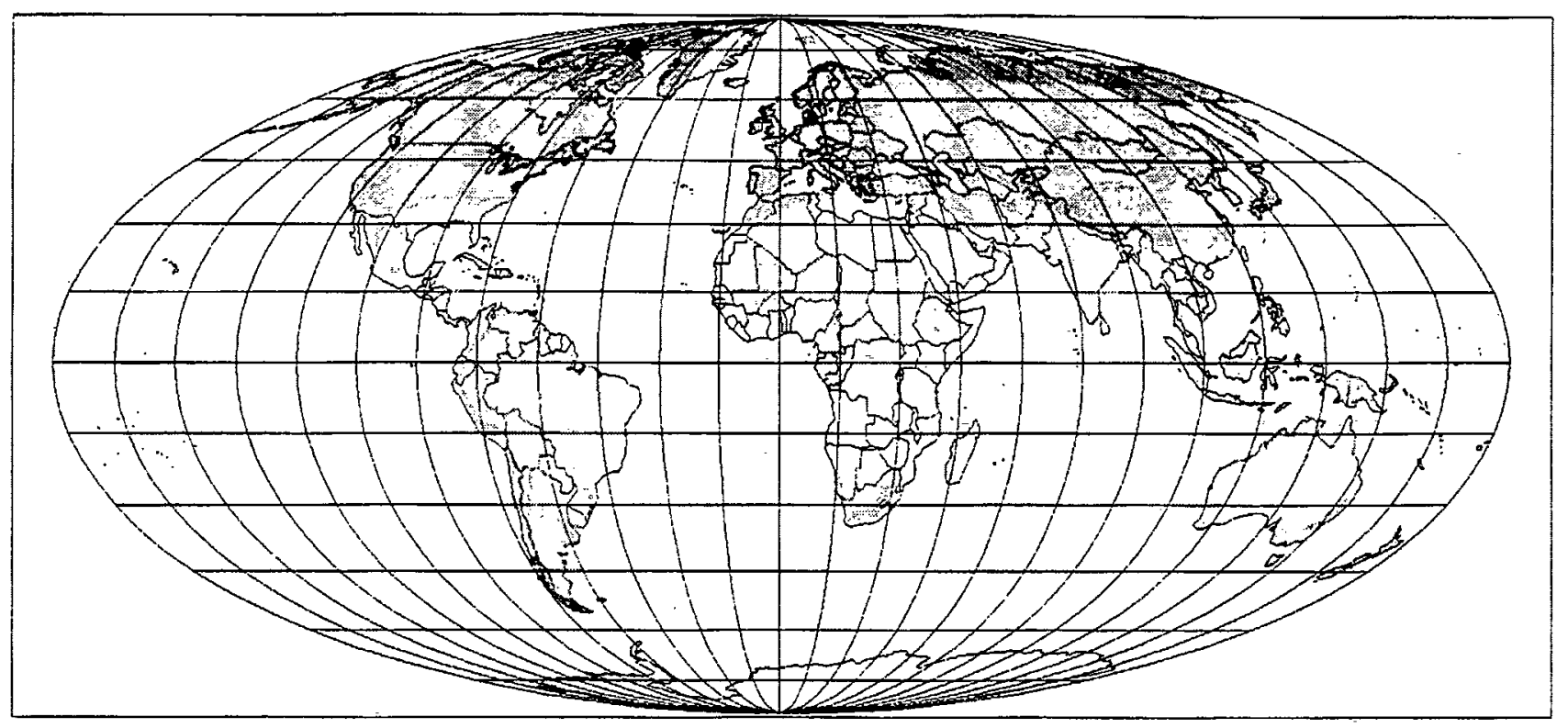

Figure 3b. April average temperatures indicating areas with space heating and cooling needs (source: Leemans and Cramer, 1998; the scale is given in Figure 3e).

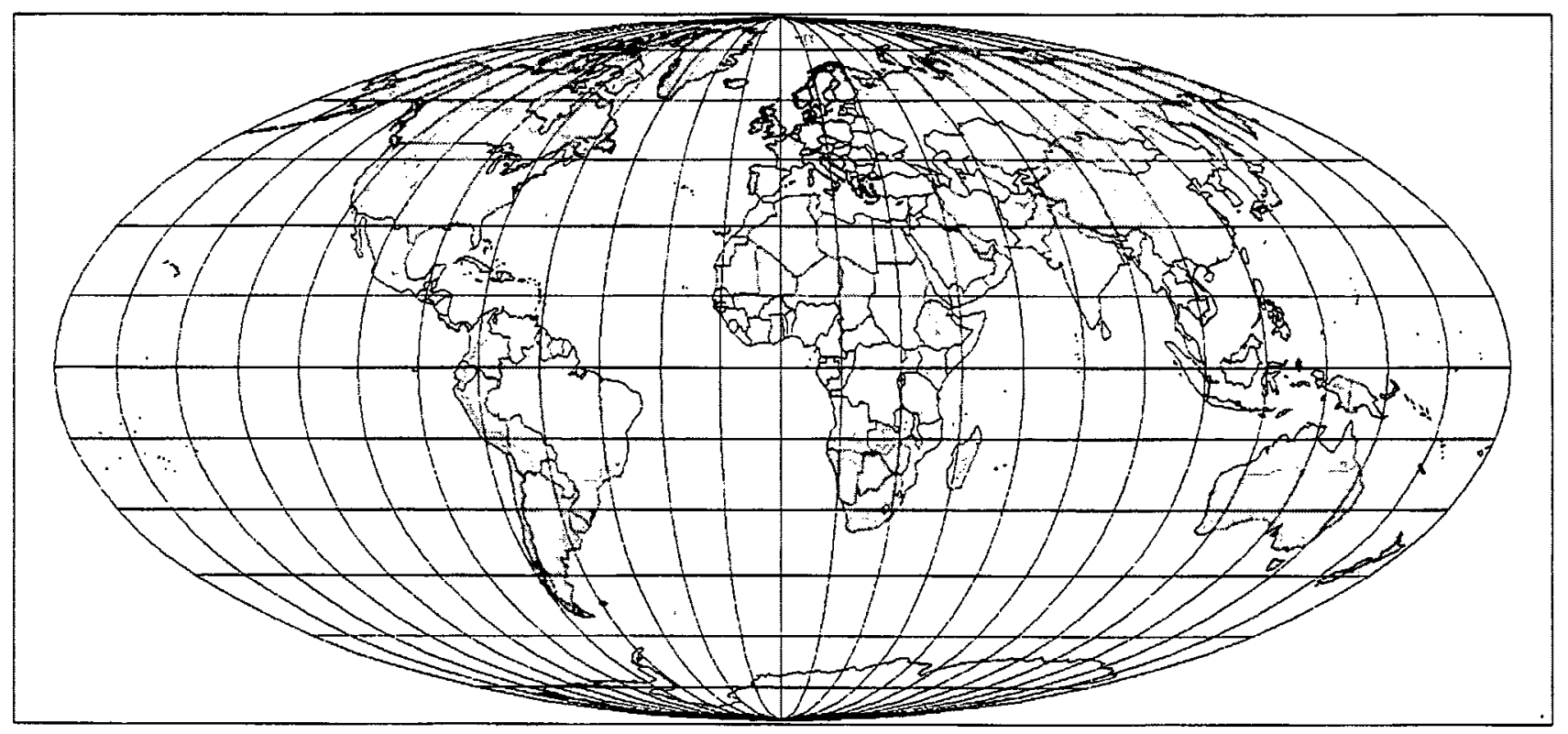

Figure 3c. July average temperatures indicating areas with space heating and cooling needs (source: Leemans and Cramer, 1998; the scale is given in Figure 3e). 


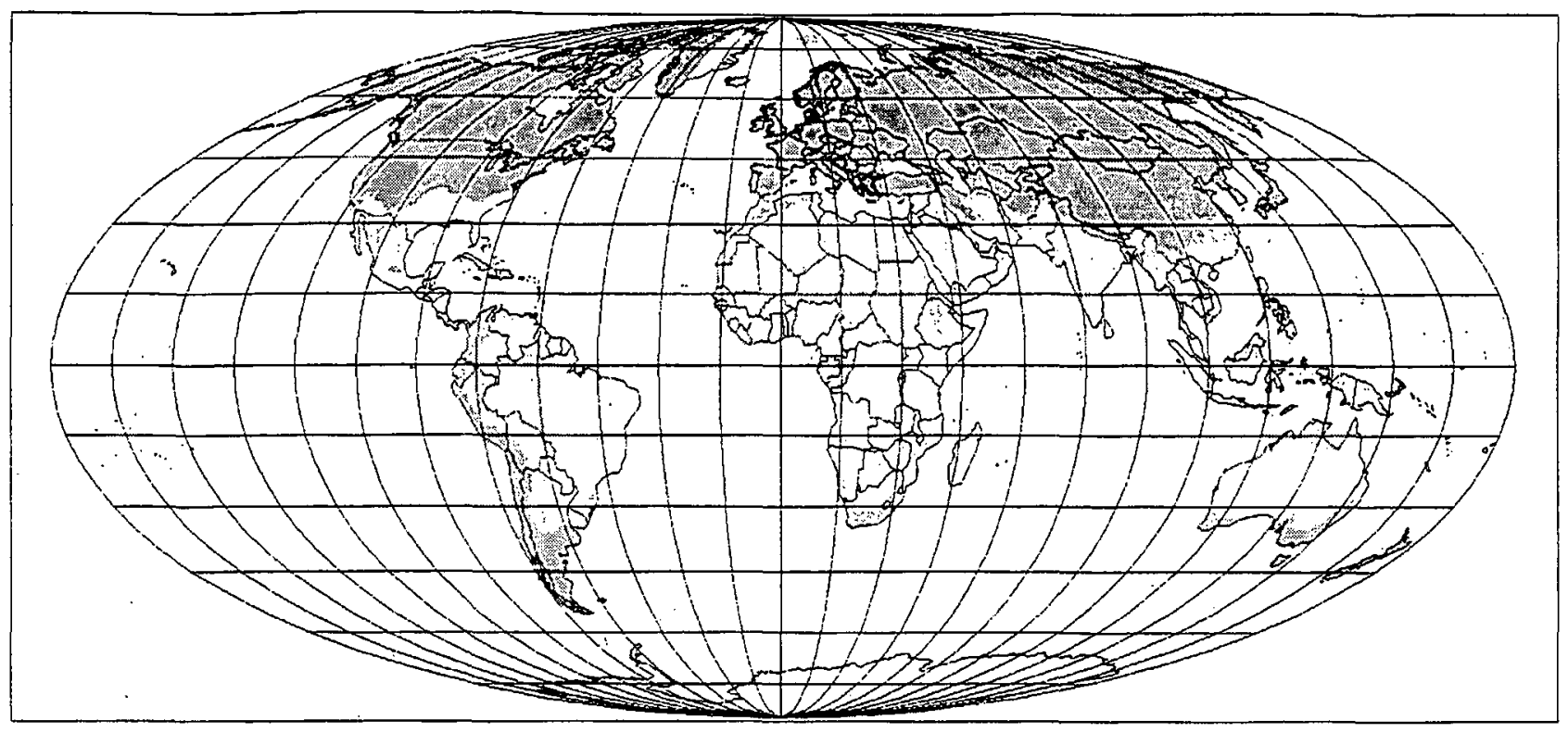

Figure 3d. October average temperatures indicating areas with space heating and cooling needs (source: Leemans and Cramer, 1998; the scale is given in Figure 3e).

Figure 3e. Temperature scale (deg. C)

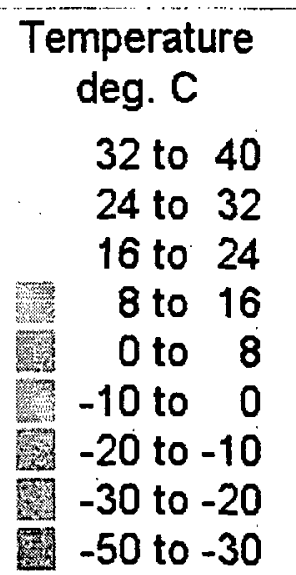




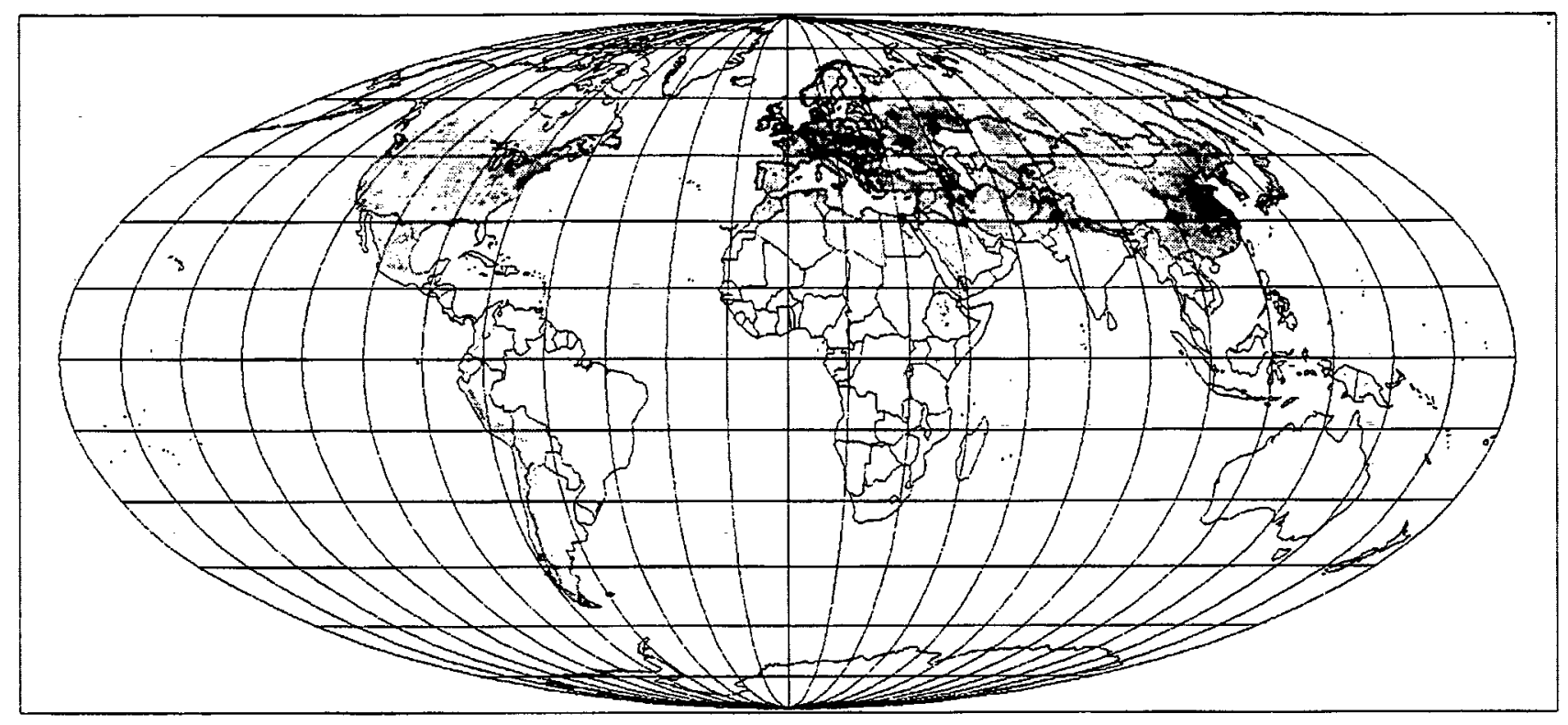

Figure 4a. January space heating energy requirements for full satisfaction of indoor comfort needs (scale given in Figure 4e).

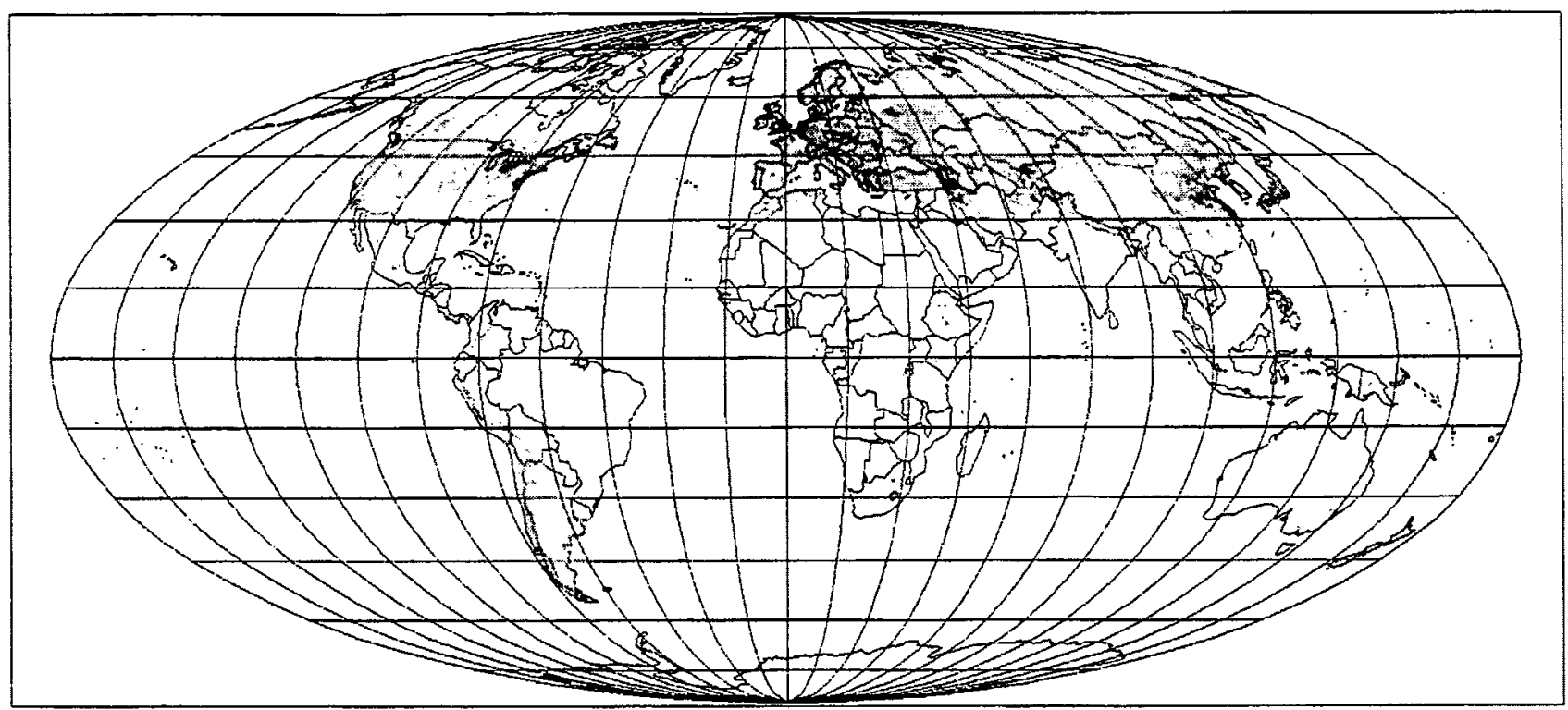

Figure 4b. April space heating energy requirements for full satisfaction of indoor comfort needs (scale given in Figure 4e). 


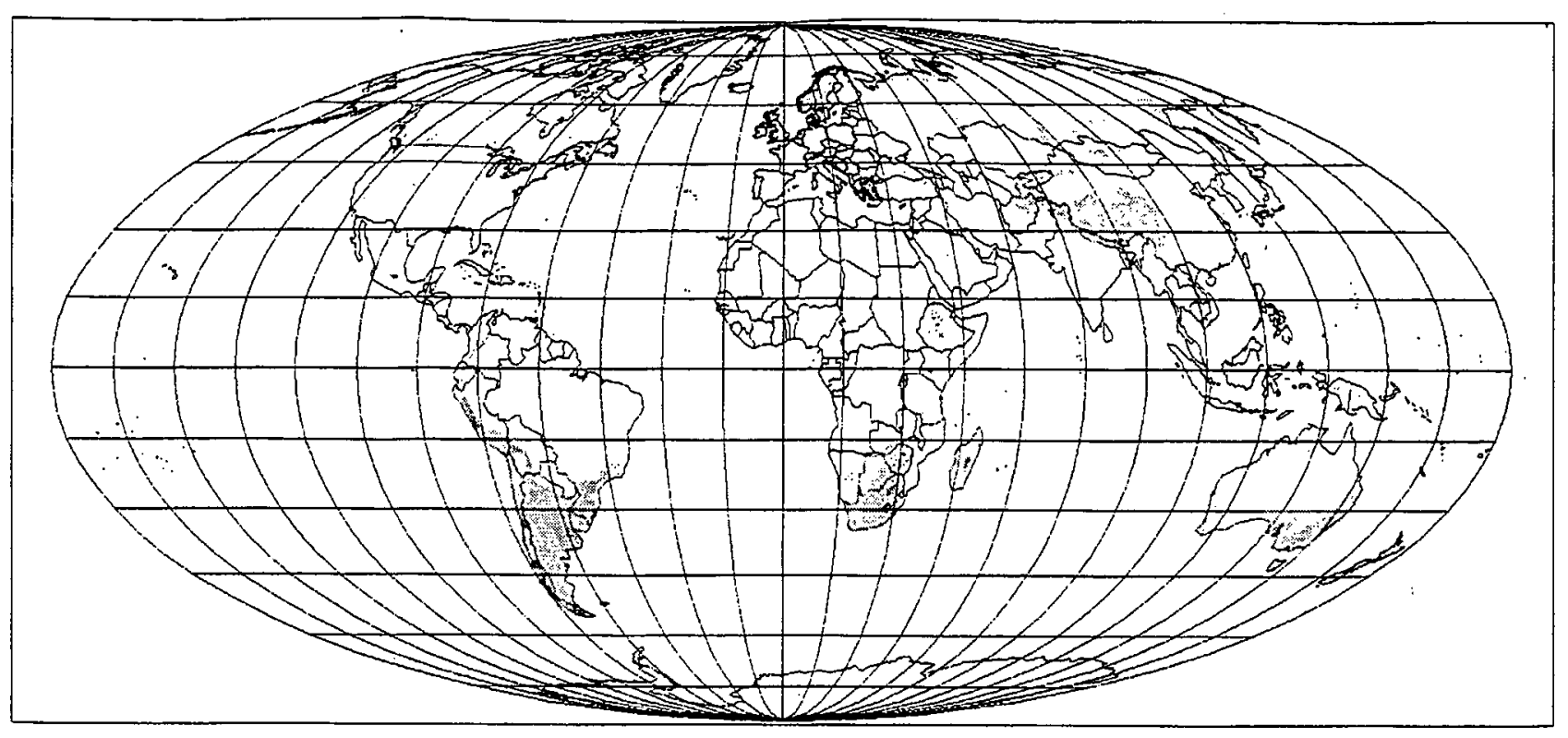

Figure 4c. July space heating energy requirements for full satisfaction of indoor comfort needs (scale given in Figure 4e).

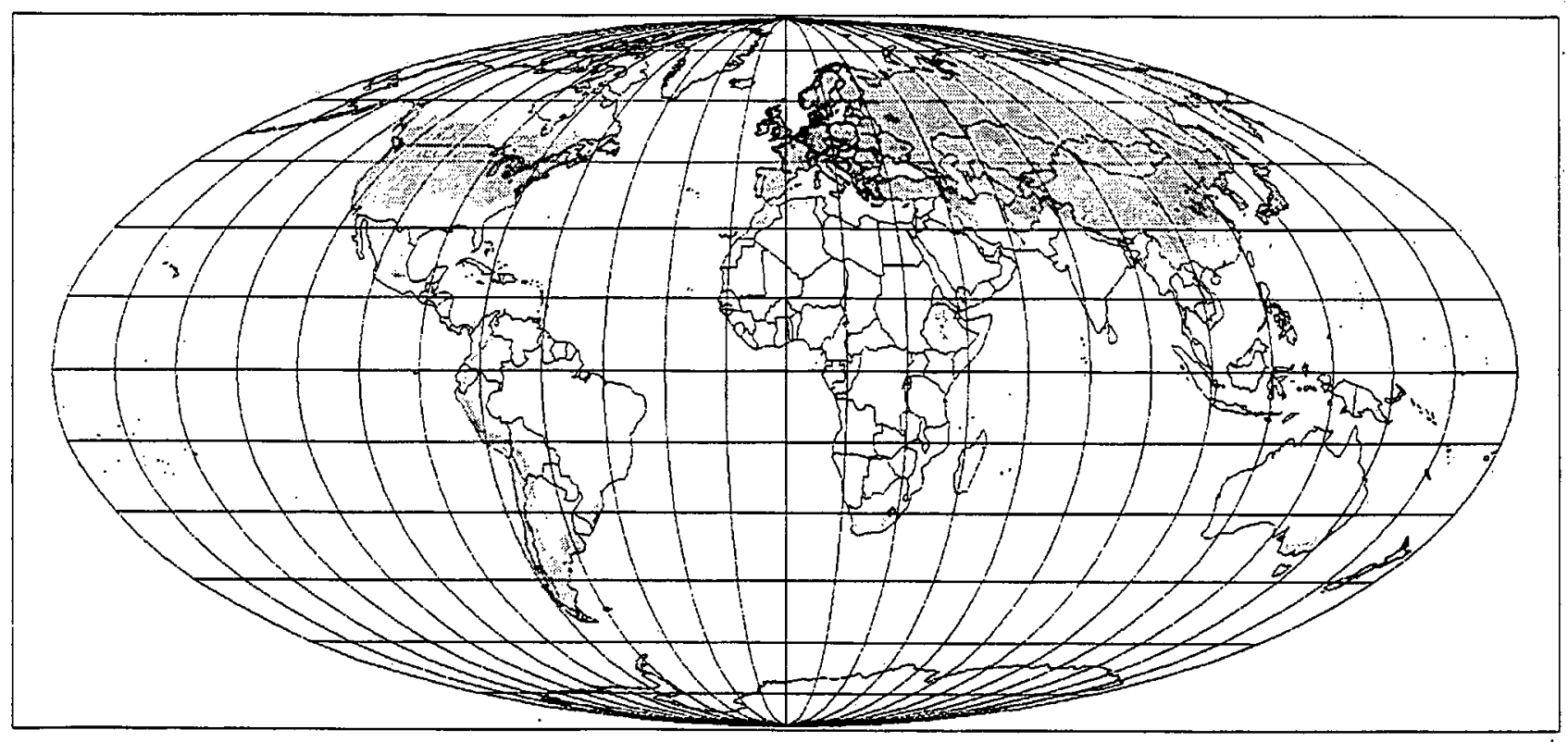

Figure 4d. October space heating energy requirements for full satisfaction of indoor comfort needs (scale given in Figure 4e). 


$\begin{array}{ll}\text { Energy flow } \\ \text { W/m2 } \\ 5 & \text { to } 10 \\ 2 & \text { to } 5 \\ 1 & \text { to } 2 \\ 0.5 & \text { to } 1 \\ 0.2 & \text { to } 0.5 \\ 0.1 & \text { to } 0.2 \\ 0.05 & \text { to } 0.1 \\ 0.02 & \text { to } 0.05 \\ 0.01 & \text { to } 0.02 \\ 0.005 & \text { to } 0.01 \\ 0.002 & \text { to } 0.005 \\ 0.0001 \text { to } 0.002 \\ \text { all others }\end{array}$

Figure 4e. Scale of energy flow (rate of energy capture, conversion or use, note that the scale is logarithmic $)\left(\mathrm{W} / \mathrm{m}^{2}\right)$.

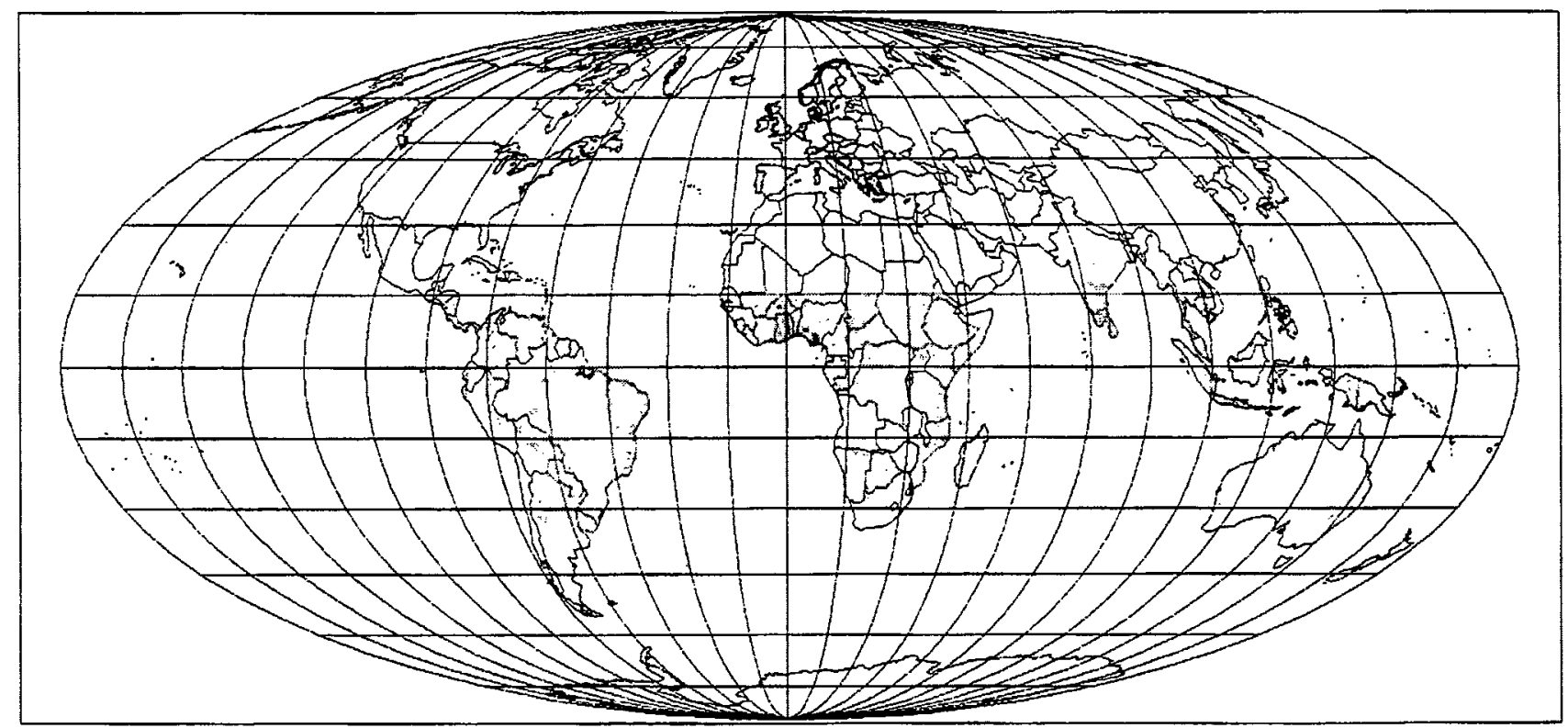

Figure 5a. January space cooling energy requirements for full satisfaction of indoor comfort needs (scale given in Figure 4e). 


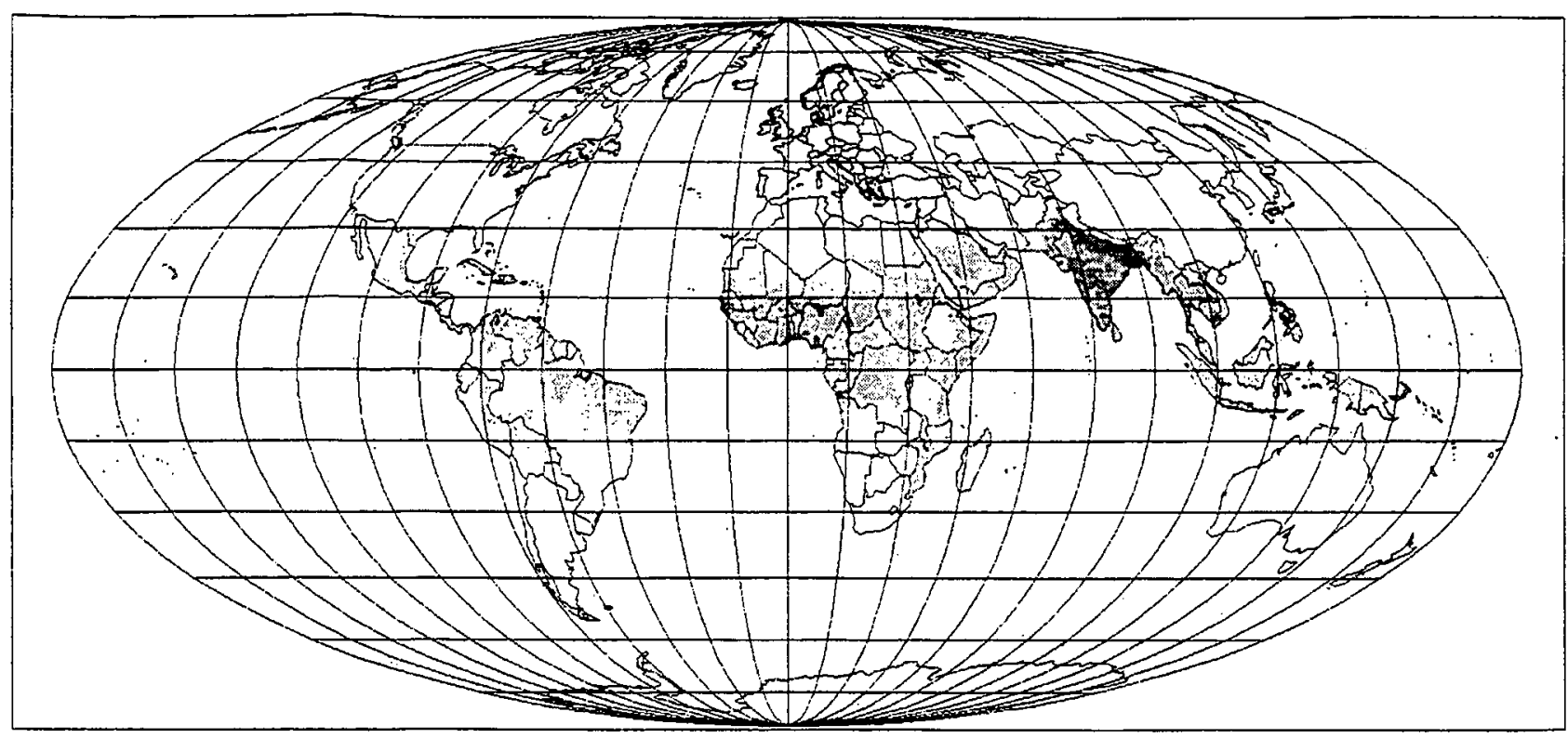

Figure 5b. April space cooling energy requirements for full satisfaction of indoor comfort needs (scale given in Figure 4e).

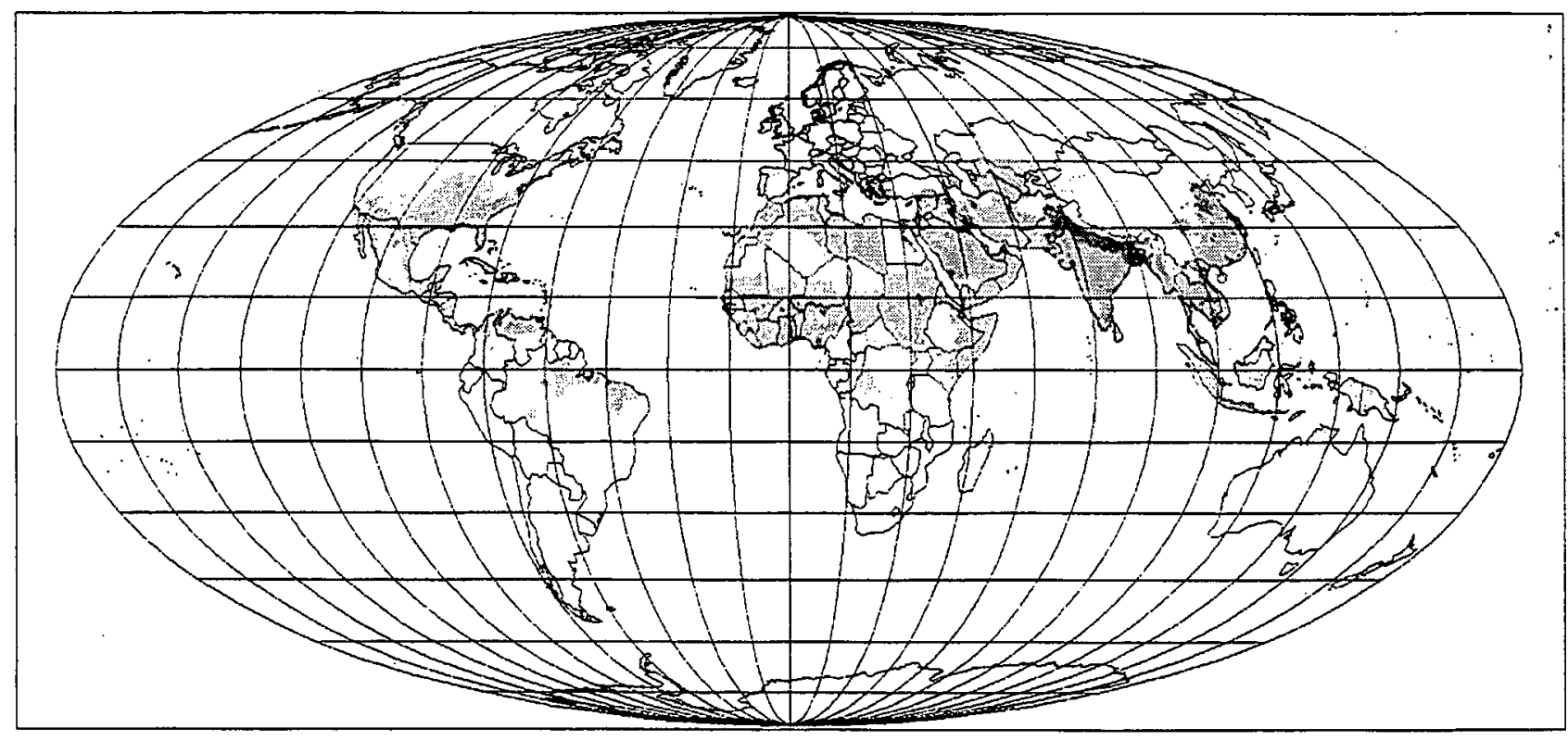

Figure 5c. July space cooling energy requirements for full satisfaction of indoor comfort needs (scale given in Figure 4e). 


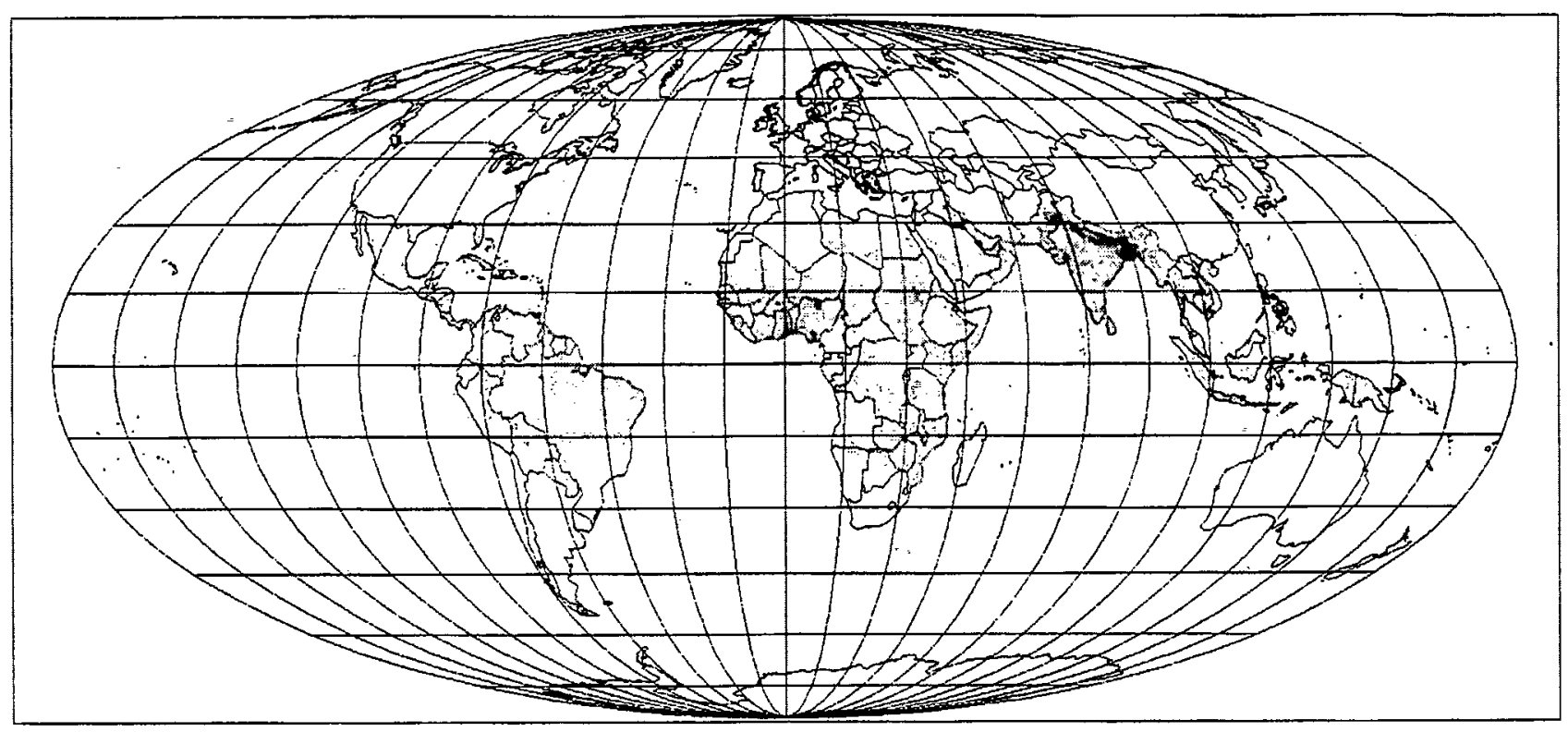

Figure 5d. October space cooling energy requirements for full satisfaction of indoor comfort needs (scale given in Figure 4e).

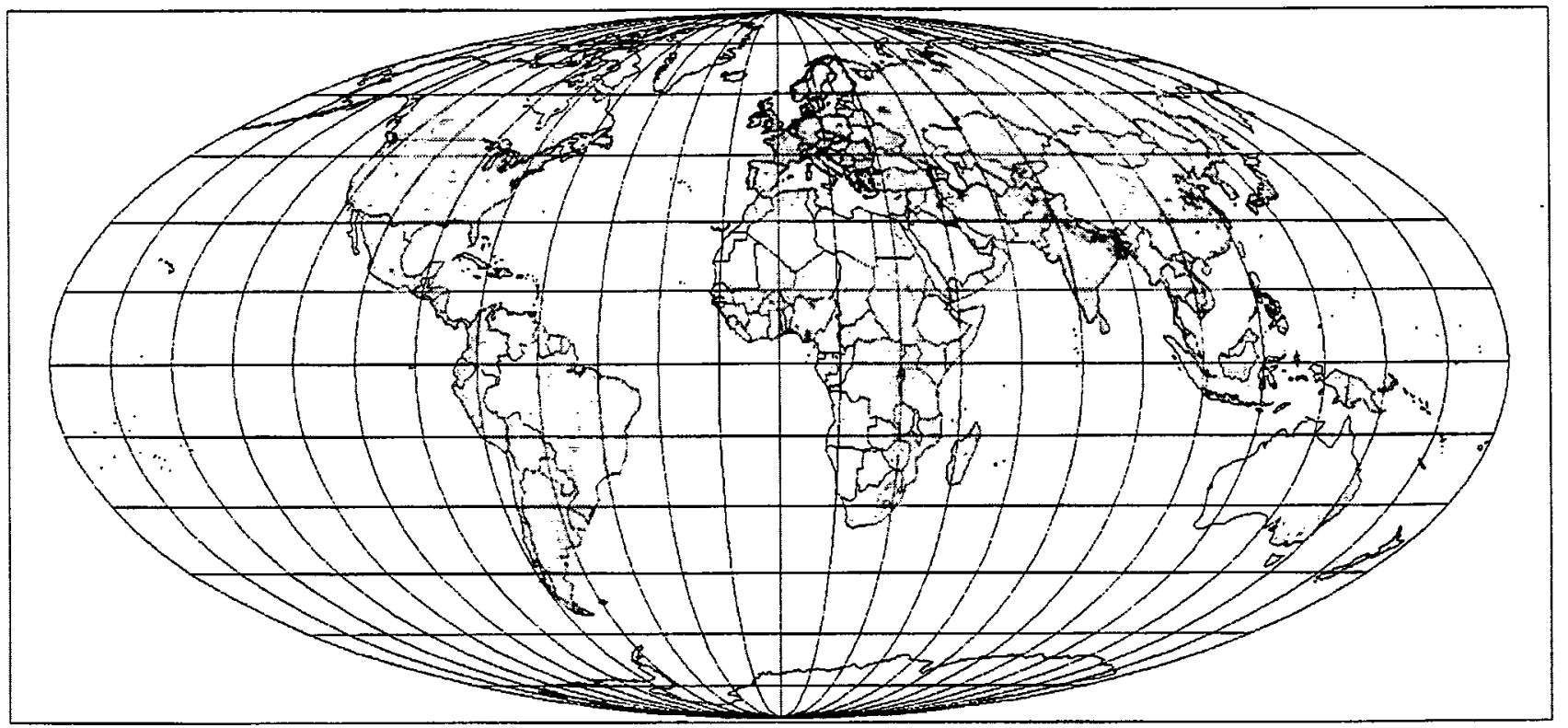

Figure 6. Annual average energy input to heat pumps producing space heating, space cooling and other low temperature heat, as delivered to consumers in 2050 scenario (scale given in Figure 4e). Annual averages in this and following figures are constructed from January, April, July and October data and may differ slightly from 12 month averages. 


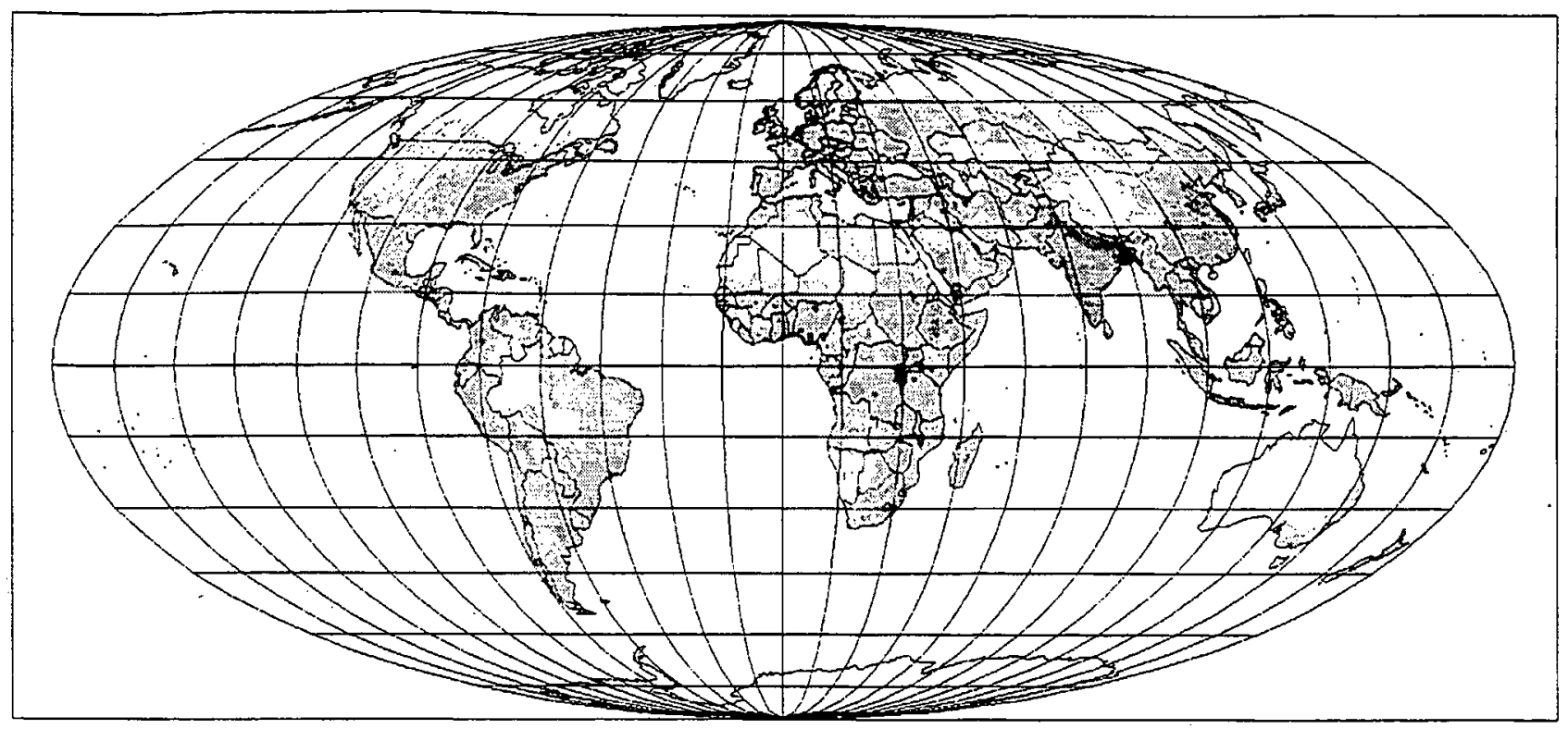

Figure 7. Gross energy content in food of vegetable type delivered to consumers in 2050 scenario (scale given in Figure 4e).

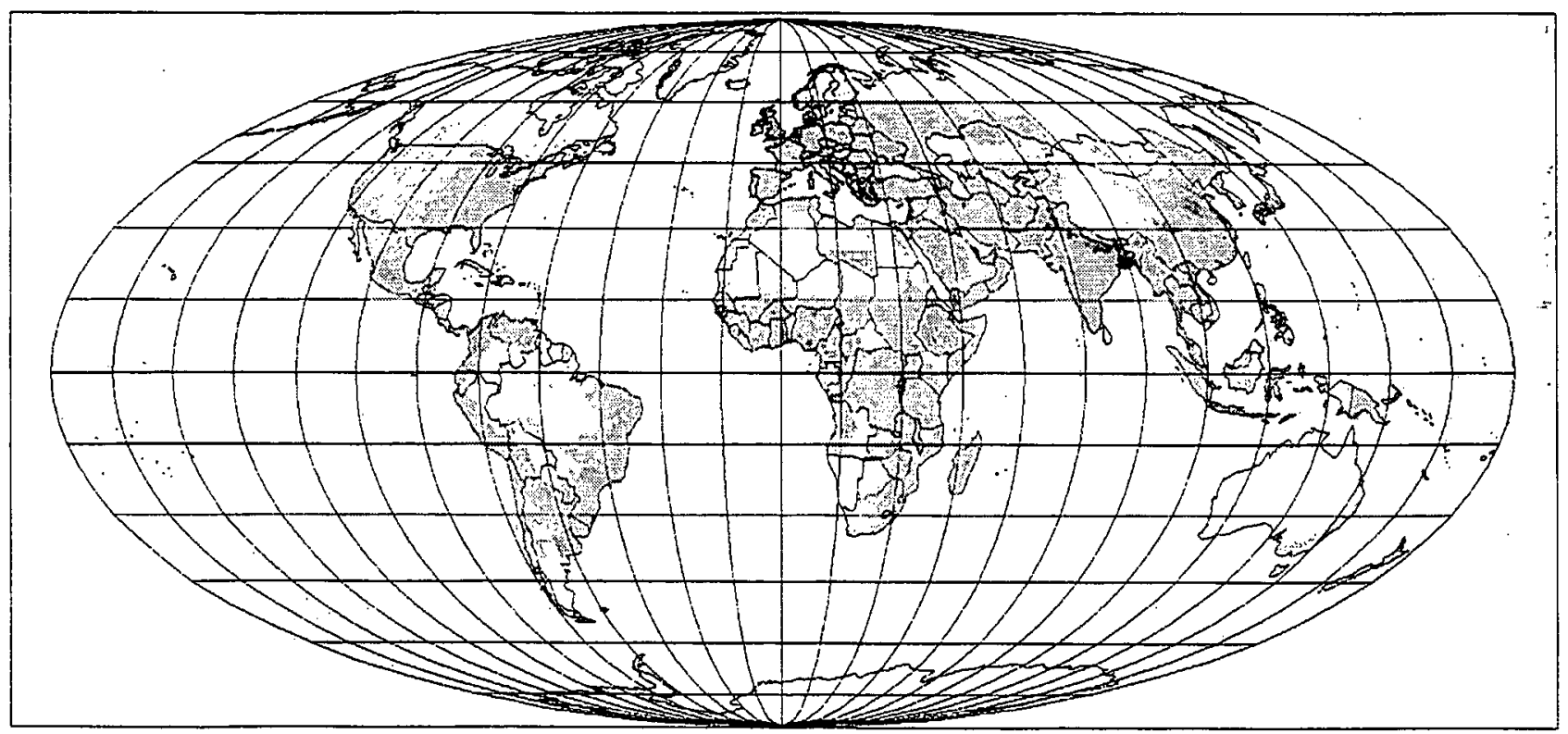

Figure 8. Gross energy content in food of animal type delivered to consumers in 2050 scenario (scale given in Figure 4e). 


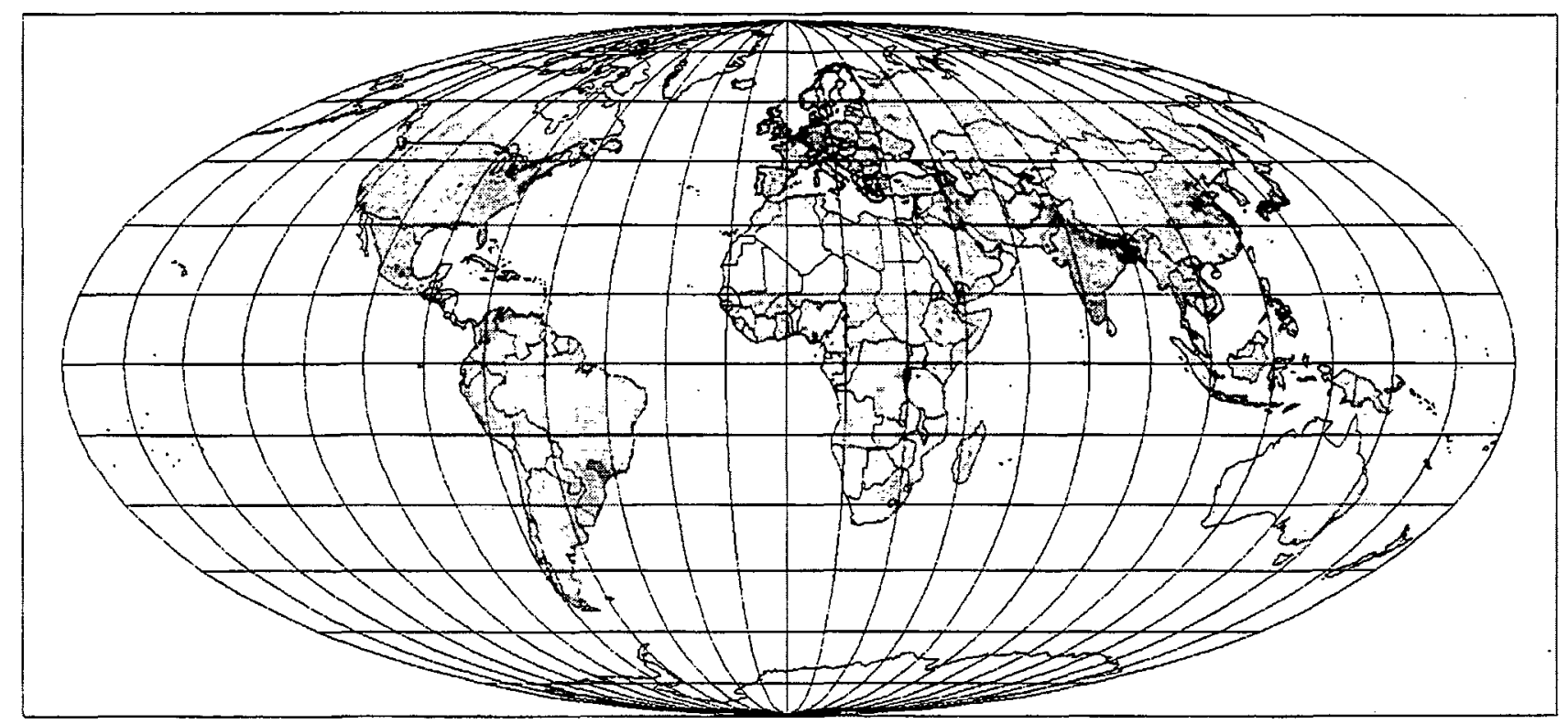

Figure 9. Gross energy demand at delivery to consumer, for all forms of transportation in the 2050 scenario (scale given in Figure 4e).

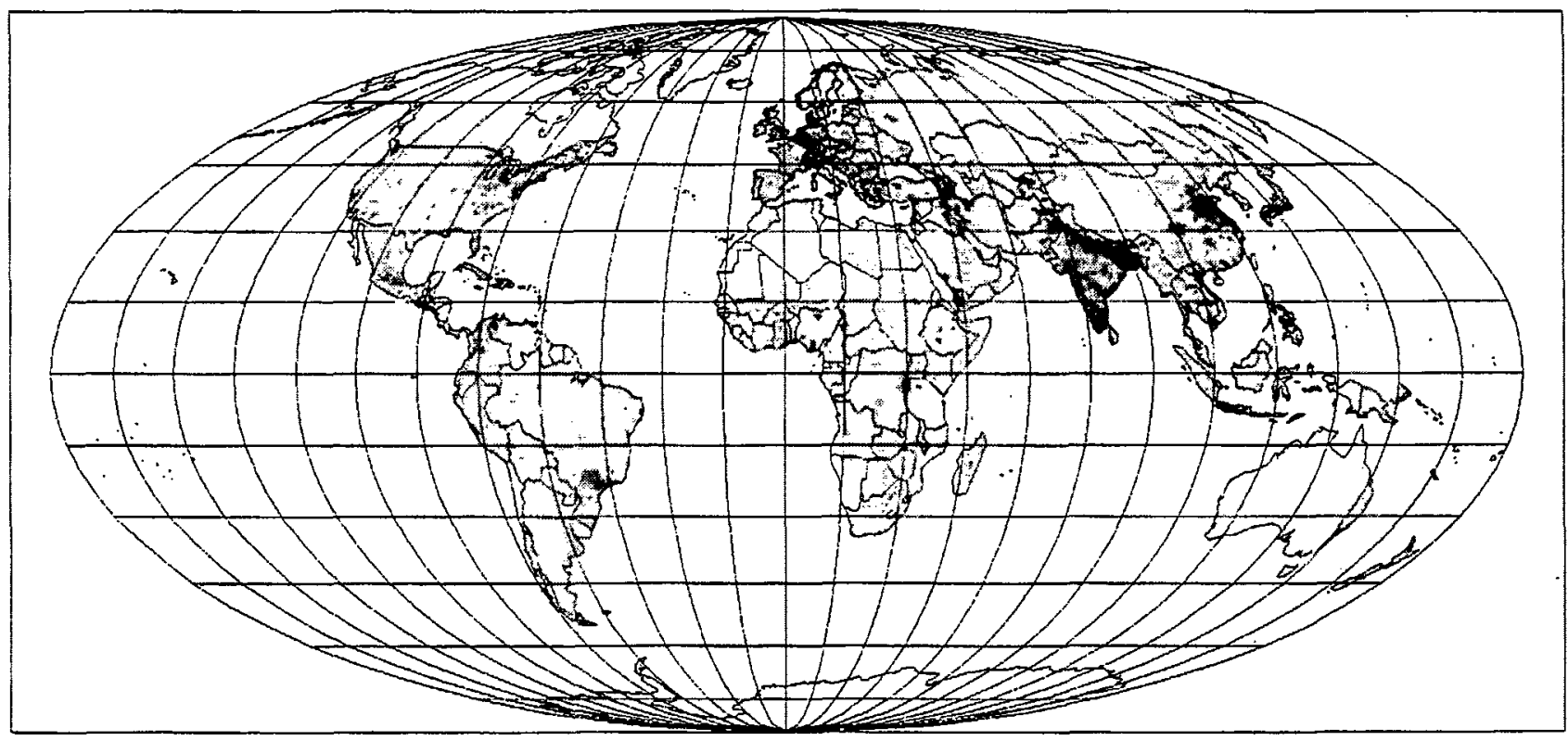

Figure 10. Energy demand at delivery to consumer, for electric energy including energy for dedicated electric appliances, stationary mechanical energy and medium- and high-temperature industrial heat. Refrigeration energy inputs other than those for space cooling are included. (scale given in Figure 4e). 


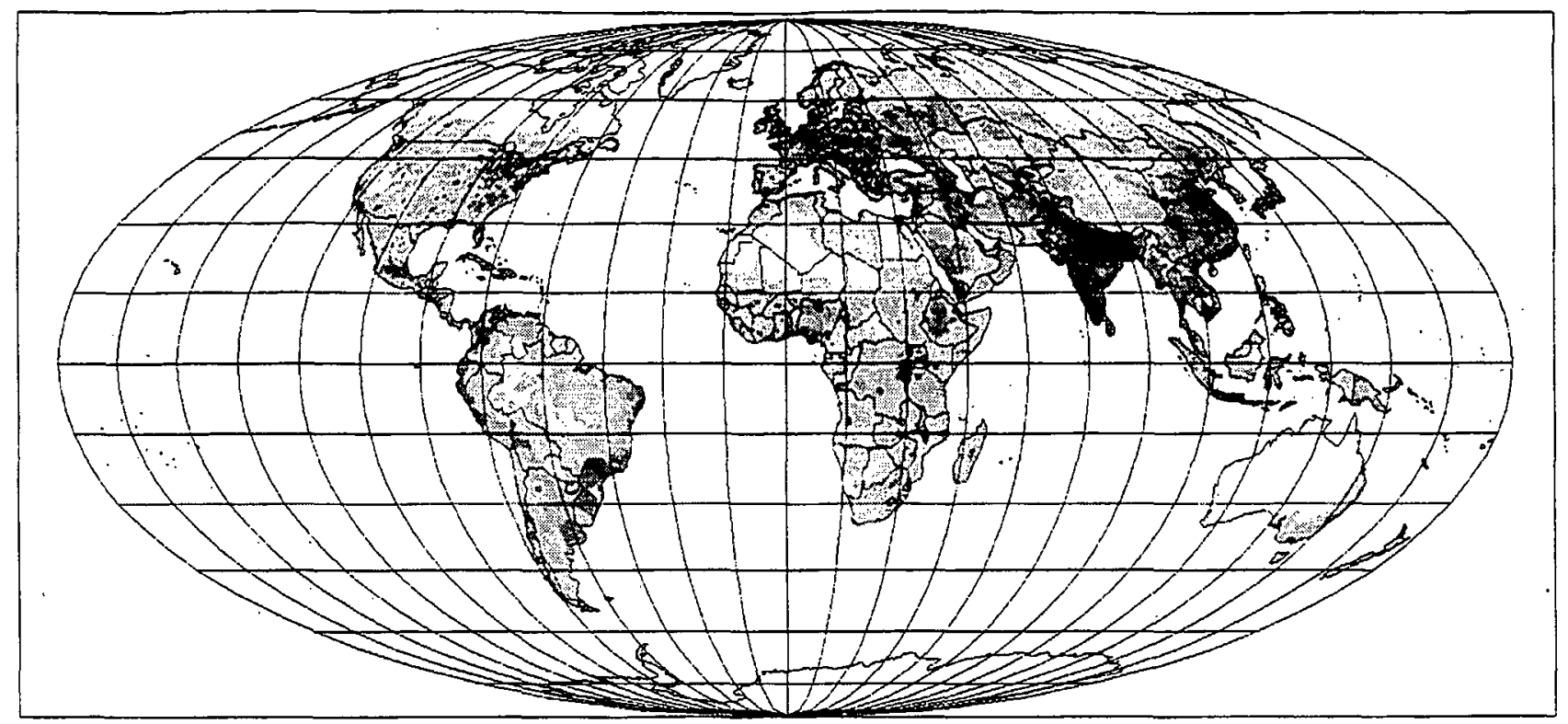

Figure 11. Total energy directly delivered to consumer in 2050 scenario (including environmental heat and the food, transportation and electricity etc. columns of Table 6) (scale given in Figure 4e).

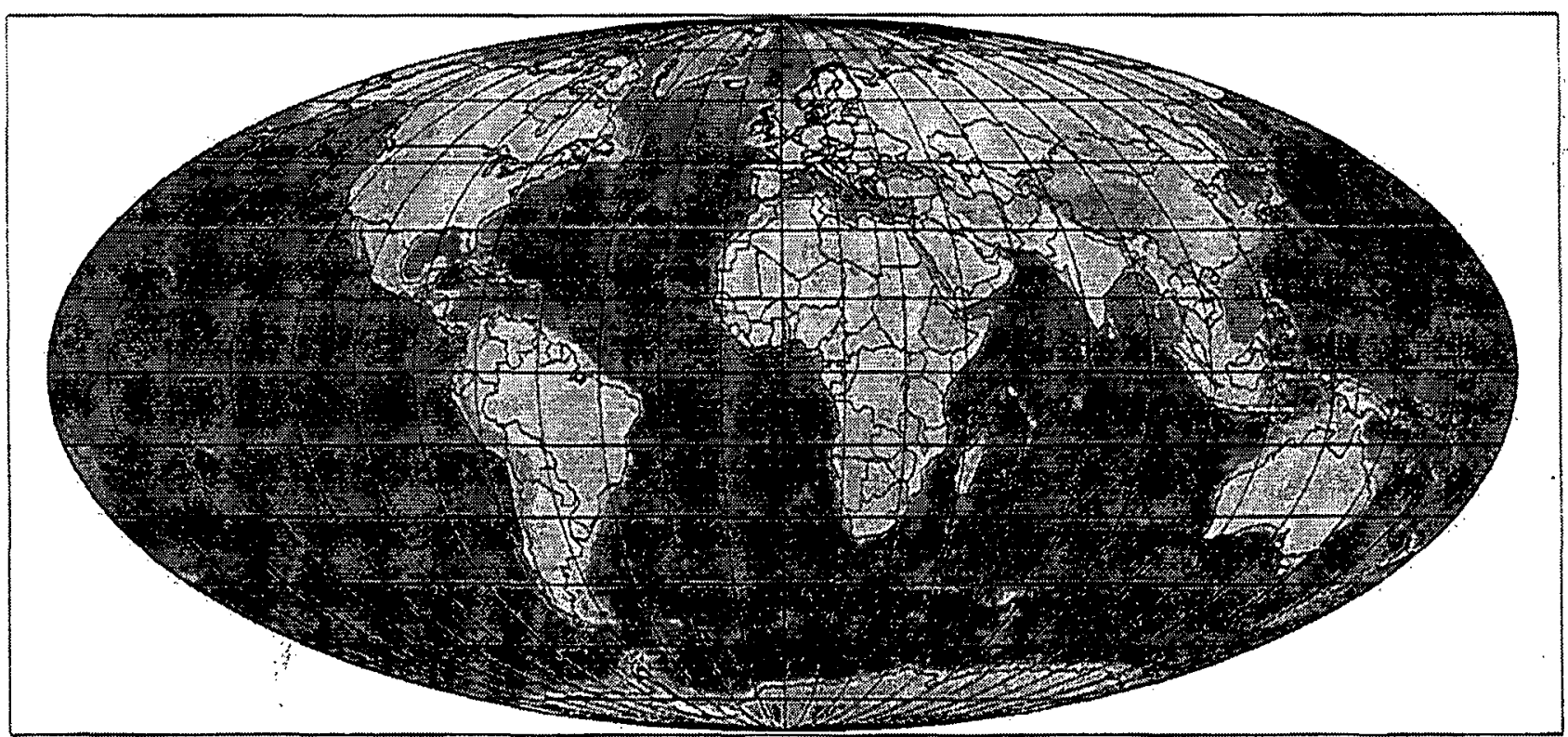

Figure 12a. Land and ocean topography (based on data from Sandwell et al., 1998) (scale given in Figure 12b). 


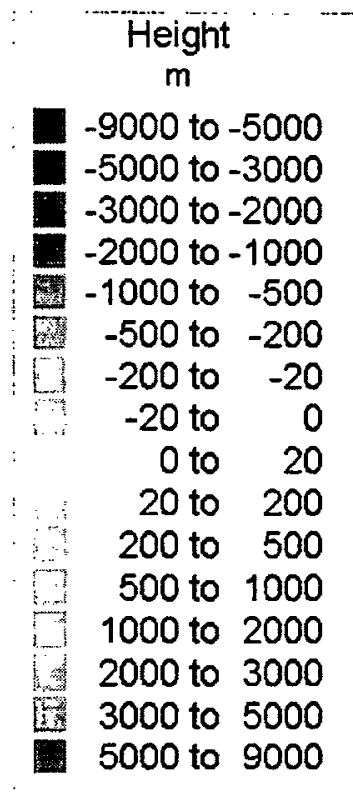

Figure 12b: Height scale relative to mean sea surface level (metres).

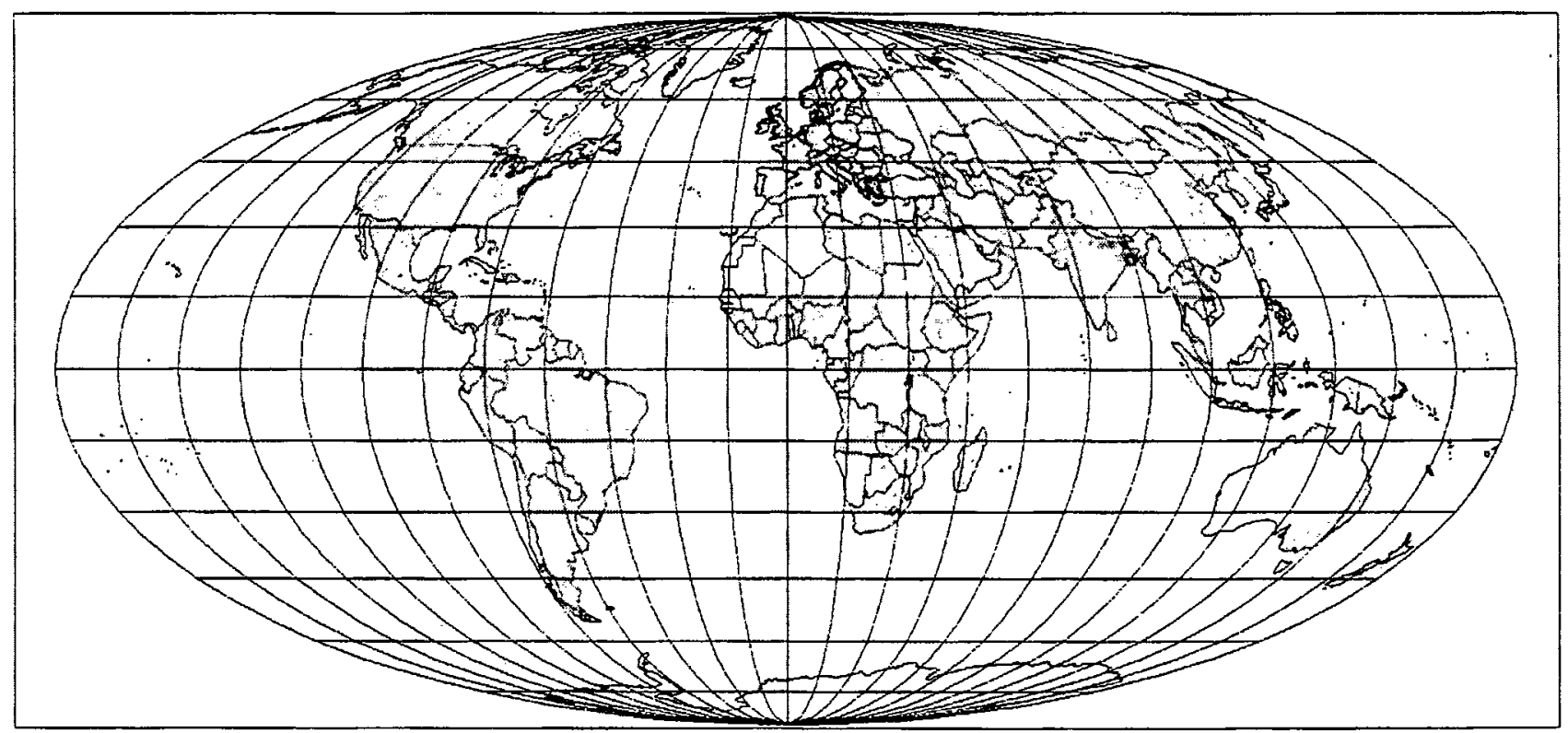

Figure 13a. Fraction of area constituted by urban or built-up land (scale given in Figure 13b). Note that high-density city centres show up poorly on a global map. 


Area fraction
0.9 to 1
0.8 to 0.9
0.7 to 0.8
0.6 to 0.7
0.5 to 0.6
0.4 to 0.5
0.3 to 0.4
0.2 to 0.3
0.1 to 0.2
0.001 to 0.1
all others

Figure 13b. Scale of area use fractions.

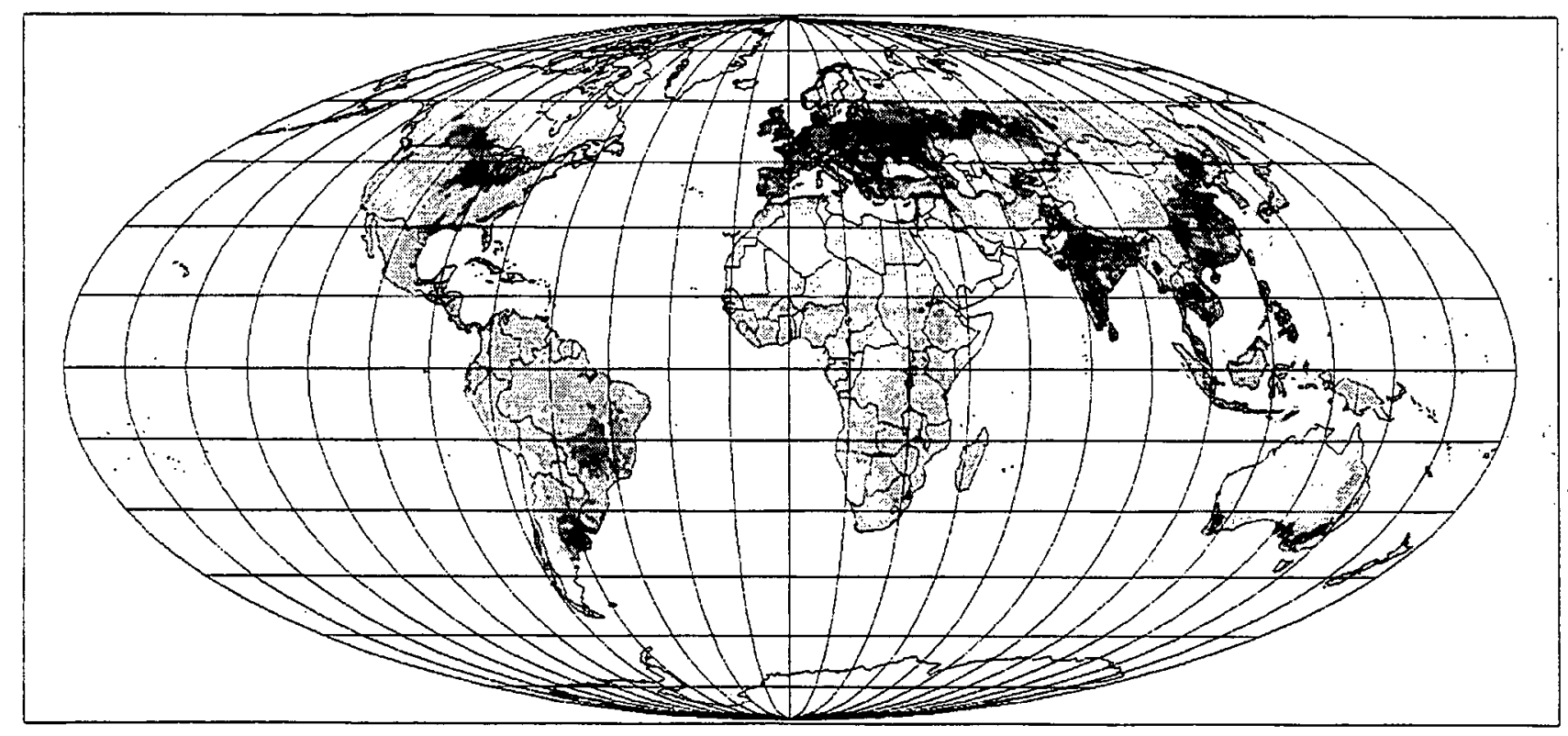

Figure 14. Fraction of area constituted by cropland and cropland in rotation (based on US Geological Survey, 1997; scale given in Figure 13b). 


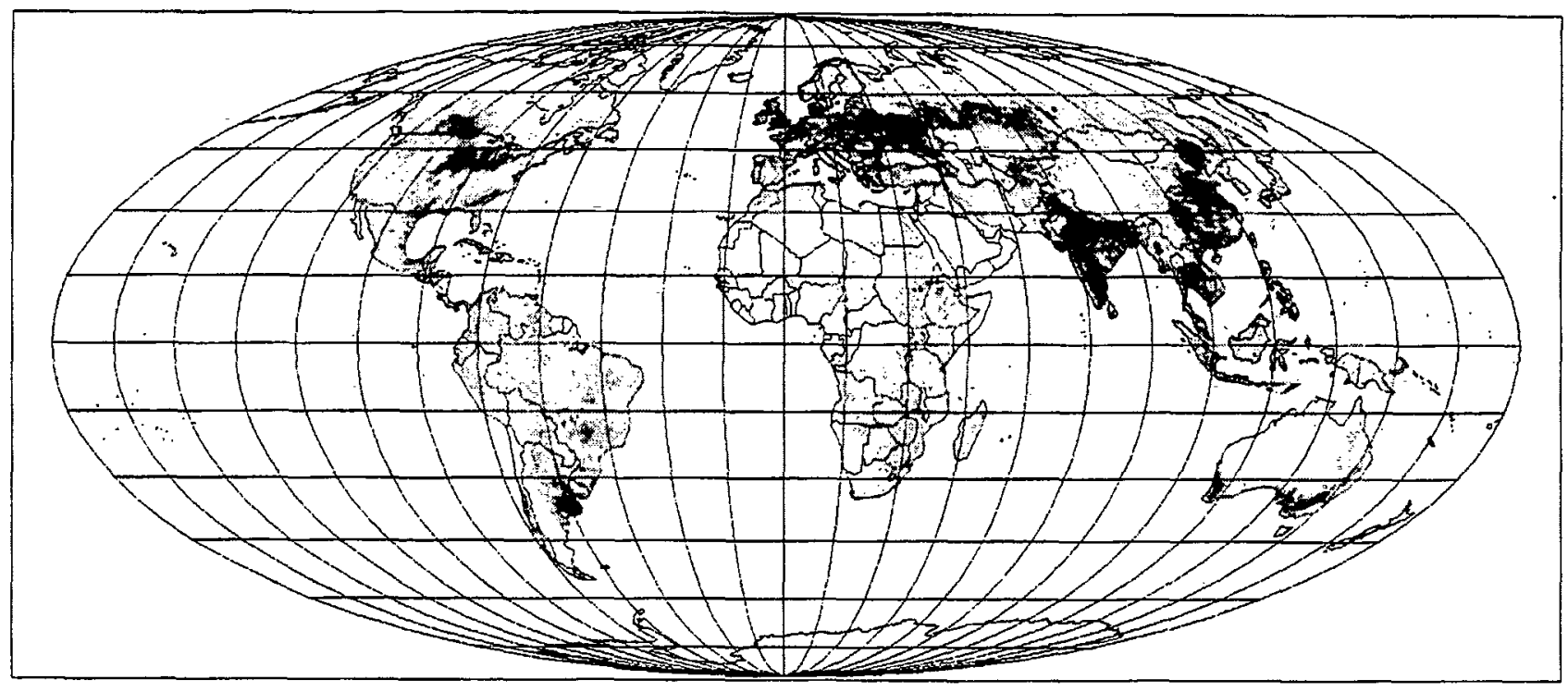

Figure 15. Fraction of area constituted by open cropland/cropland in rotation. This differs from the areas given in Figure 14 by not including cropland in mixed crop/woodland mosaics, which would not be suited for wind power production due to high roughness levels (based on US Geological Survey, 1997; scale given in Figure 13b).

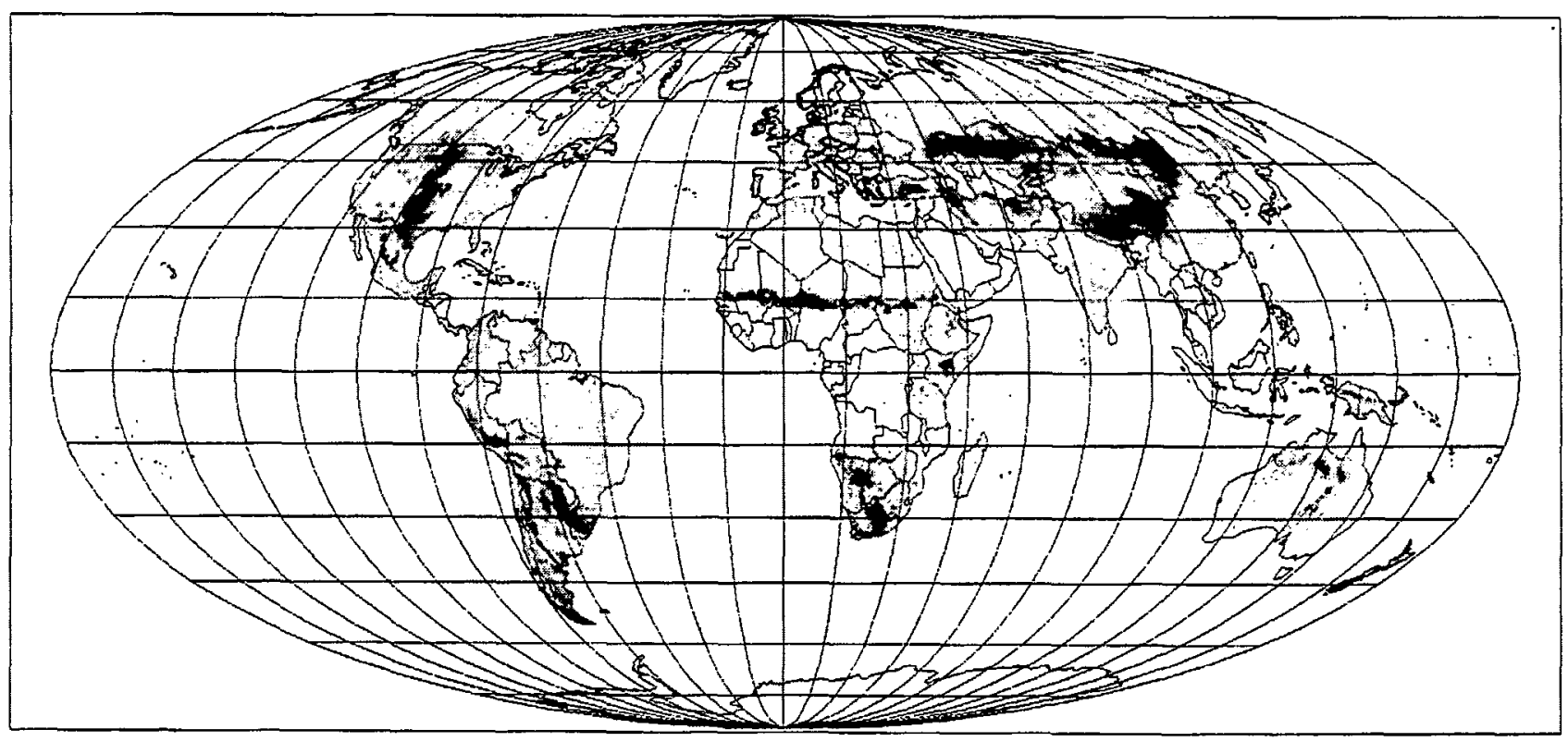

Figure 16. Fraction of area constituted by rangeland (based on US Geological Survey, 1997; scale given in Figure 13b). 


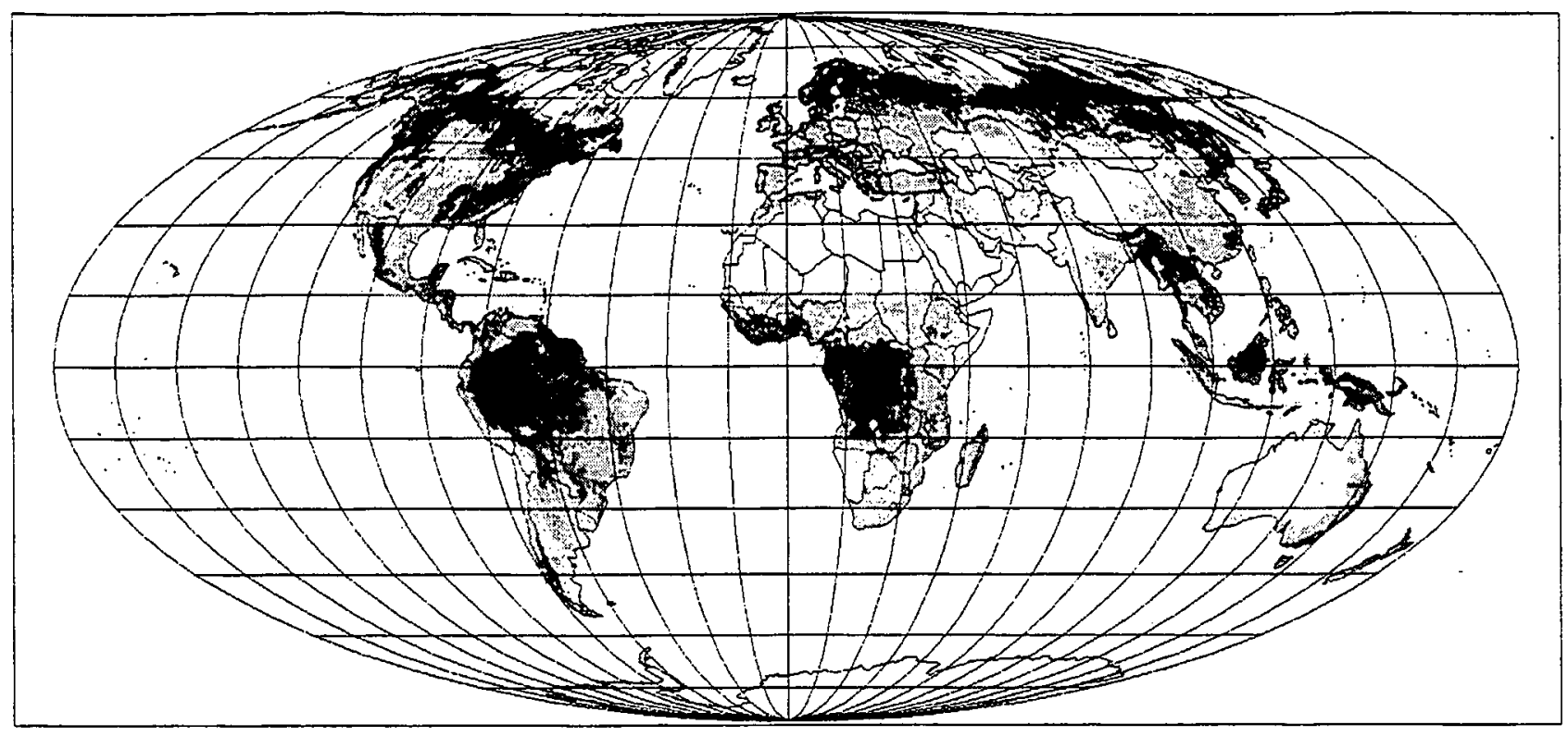

Figure 17. Fraction of area constituted by forest (based on US Geological Survey, 1997; scale given in Figure 13b).

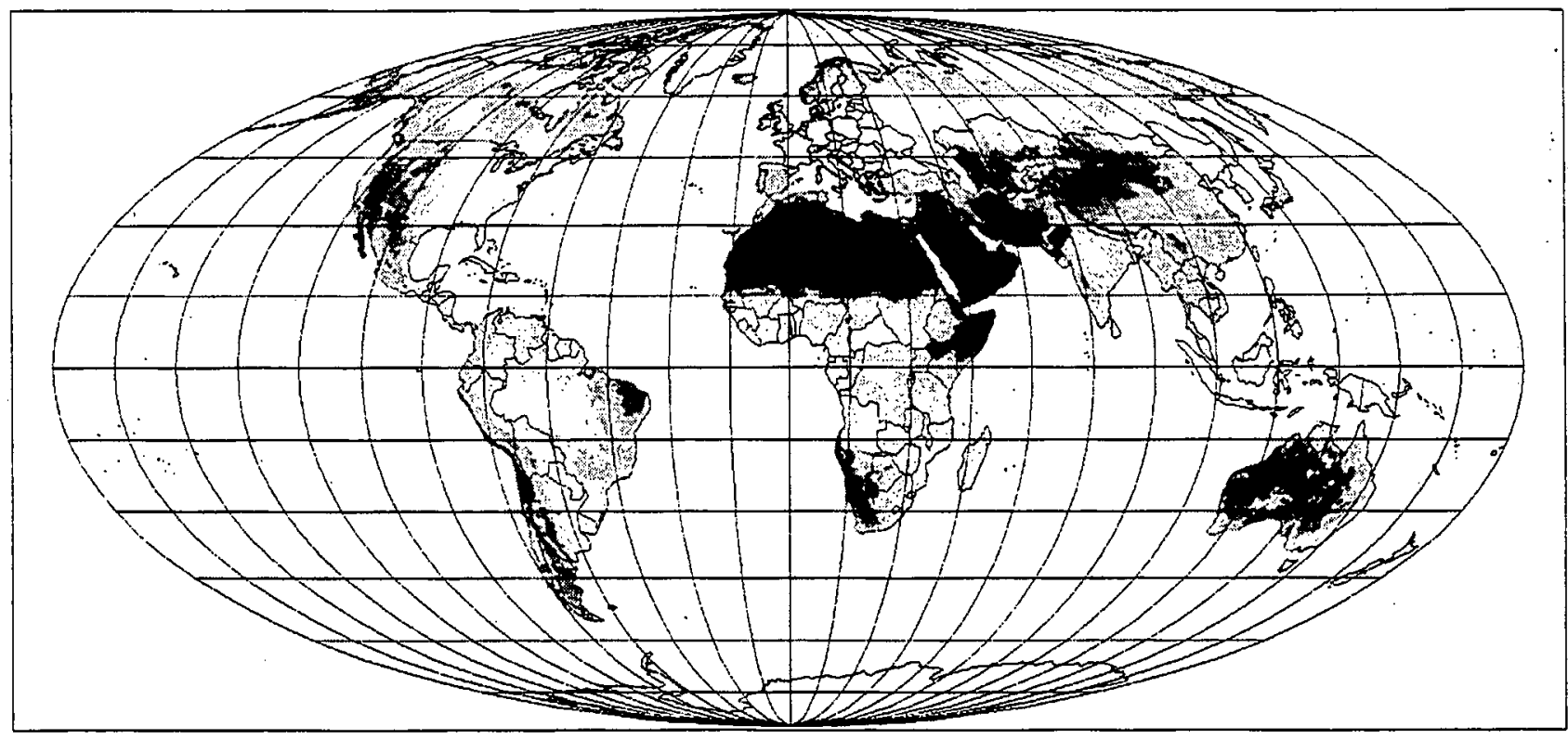

Figure 18. Fraction of area constituted by marginal land (based on US Geological Survey, 1997; scale.given in Figure 13b). 


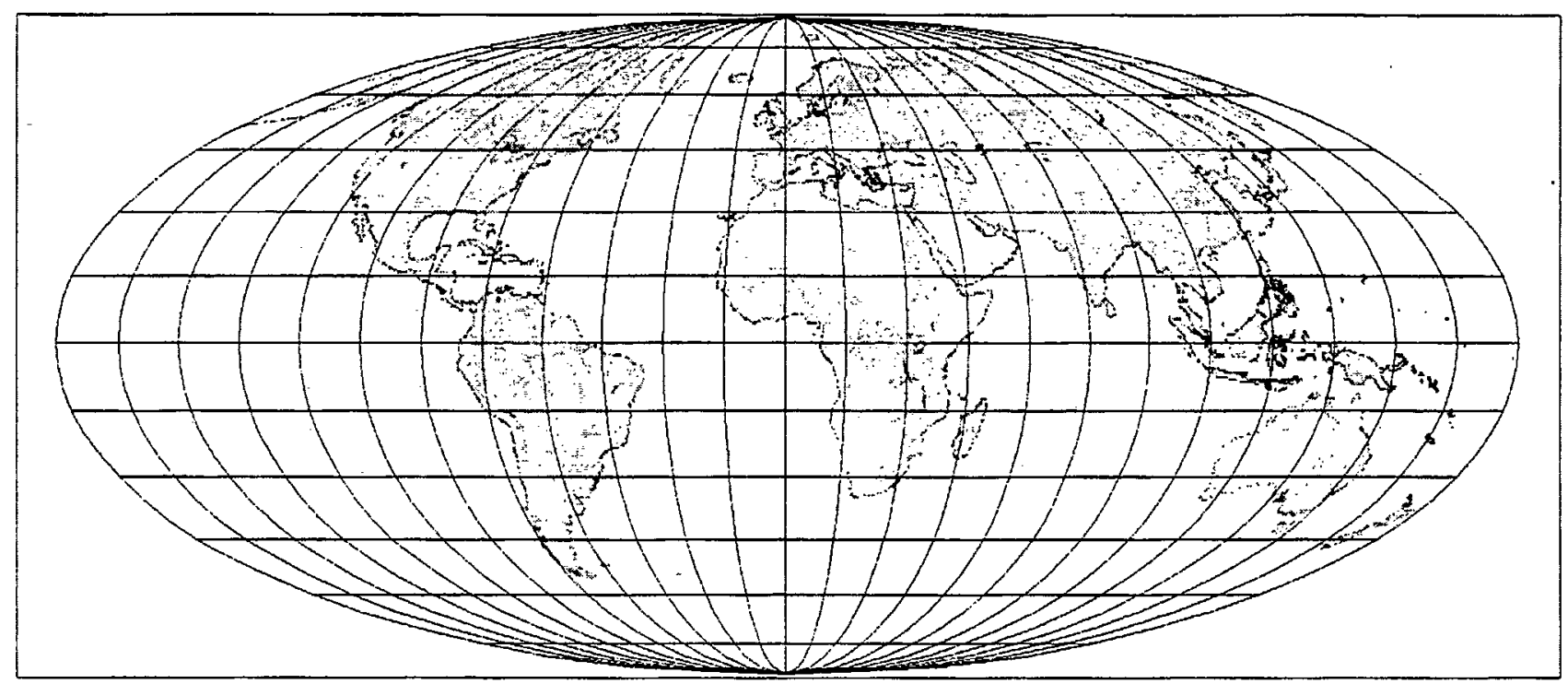

Figure 19. Fraction of "land" area constituted by water bodies (based on US Geological Survey, 1997; scale given in Figure 13b).

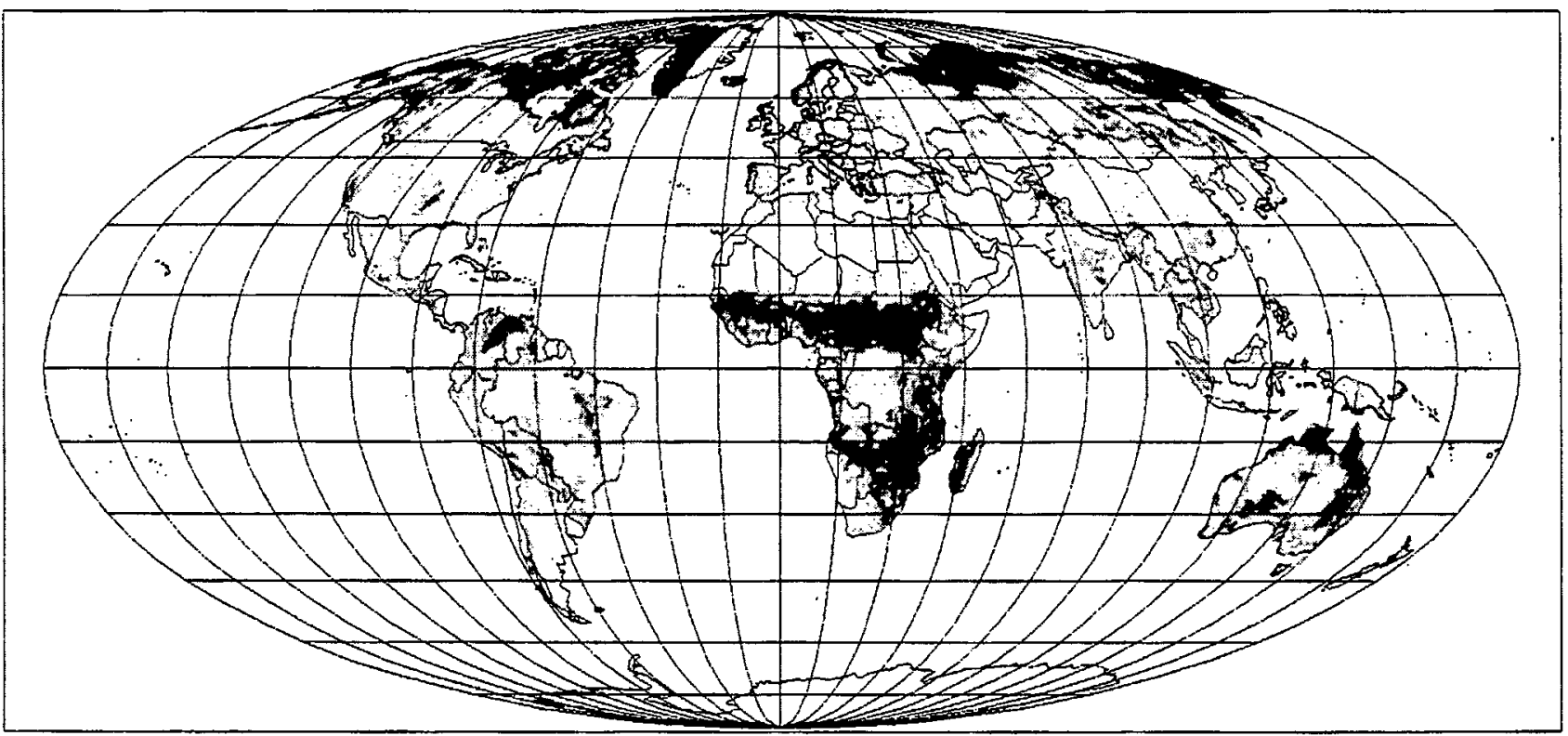

Figure 20. Fraction of area not covered by any of the categories shown in Figures 13-19 (based on US Geological Survey, 1997; scale given in Figure 13b). 


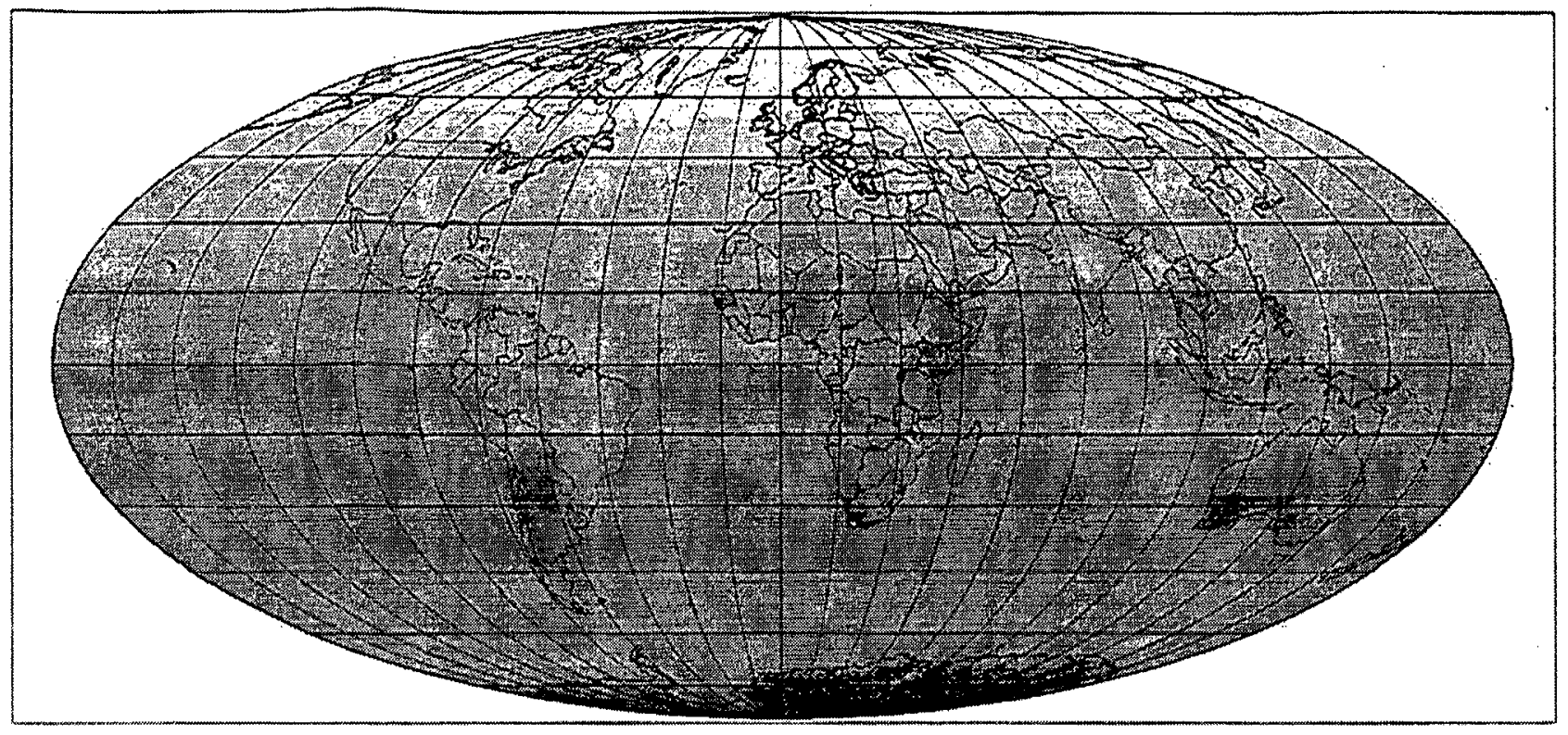

Figure 21a. January 1997 average solar radiation on horizontal surface (downward energy flux at Earth's surface) (based on NCEP/NCAR, 1998; scale given in Figure 21e).

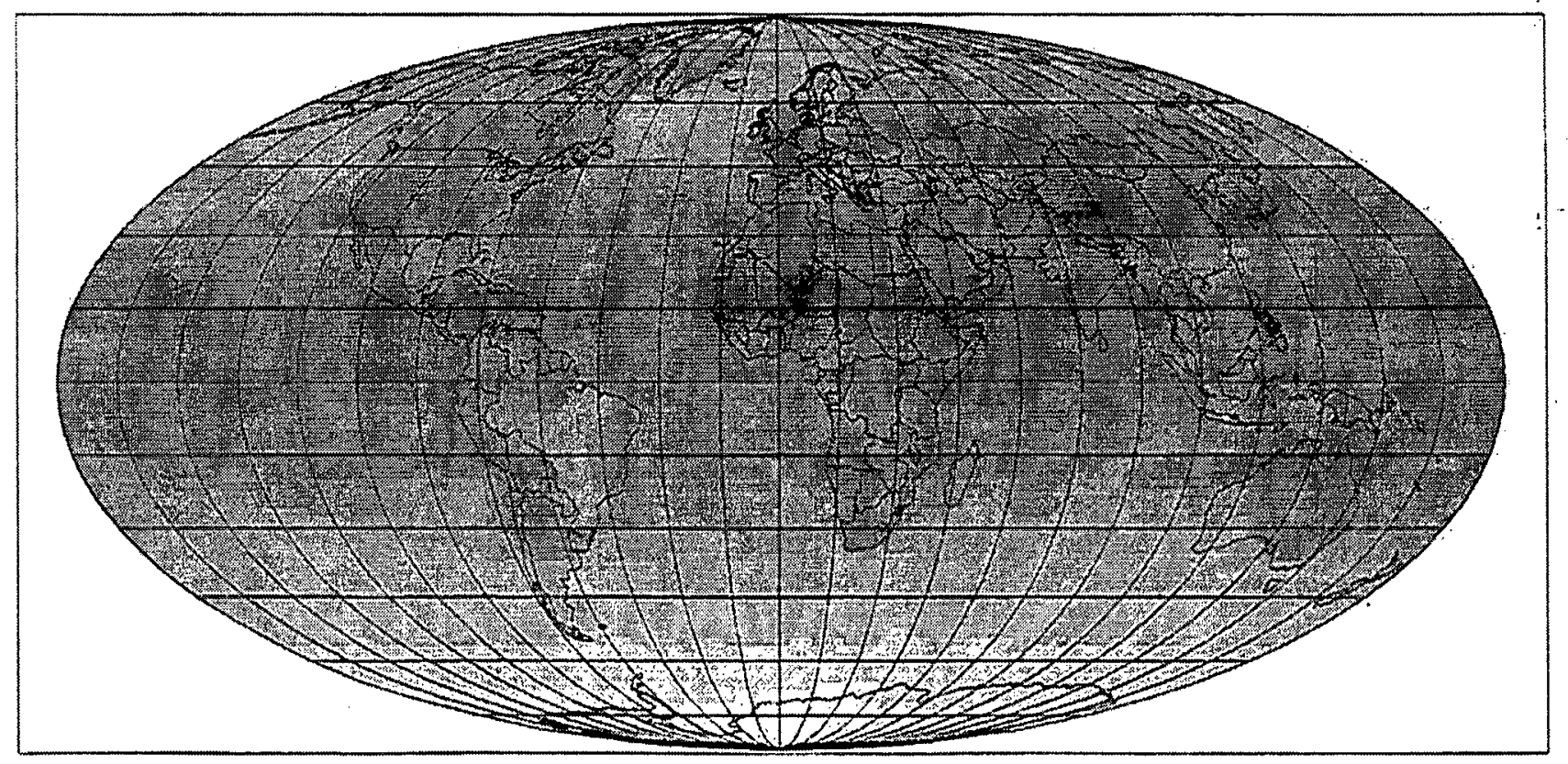

Figure 21b. April 1997 average solar radiation on horizontal surface (downward energy flux at Earth's surface) (based on NCEP/NCAR, 1998; scale given in Figure 21e). 


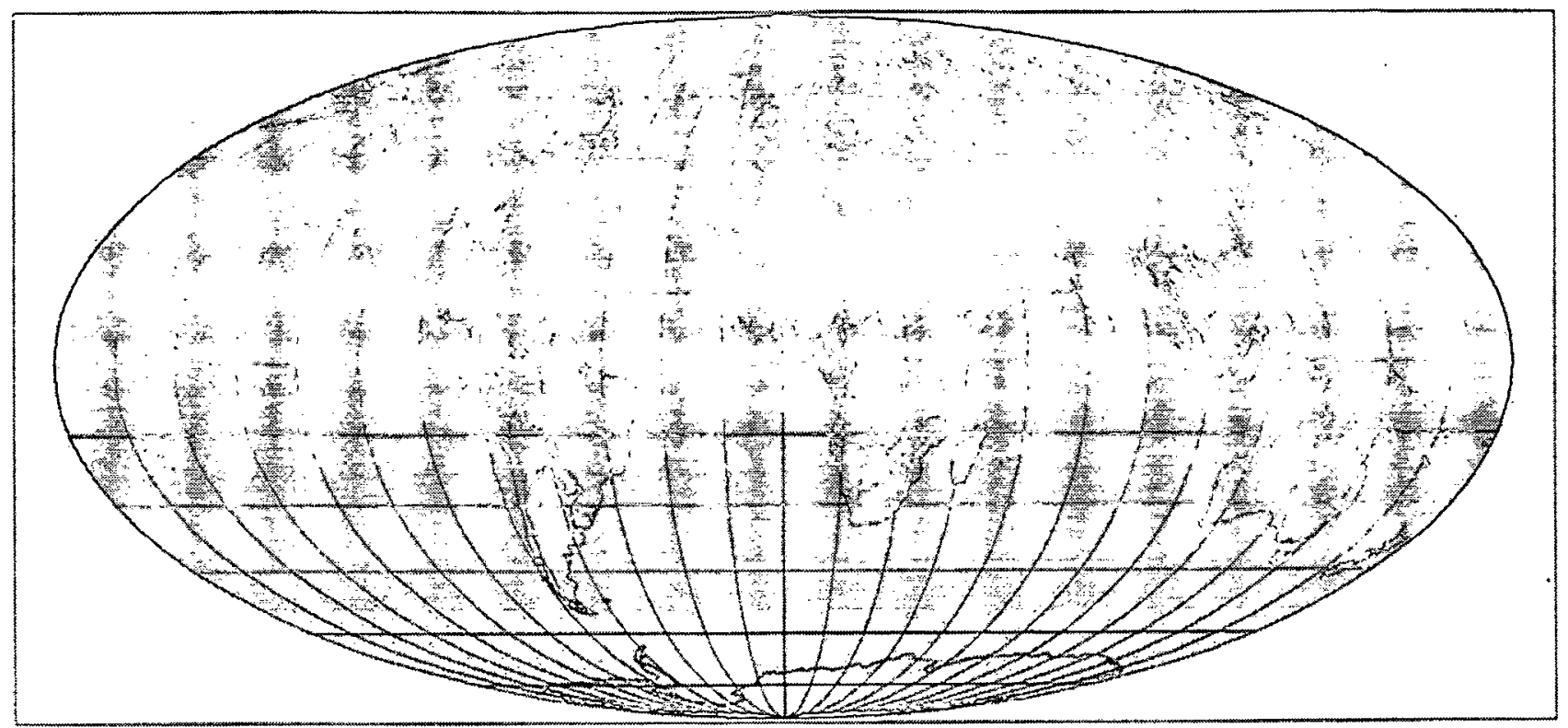

Figure 21c. July 1997 average solar radiation on horizontal surface (downward energy flux at Earth's surface) (based on NCEP/NCAR, 1998; scale given in Figure 21e).

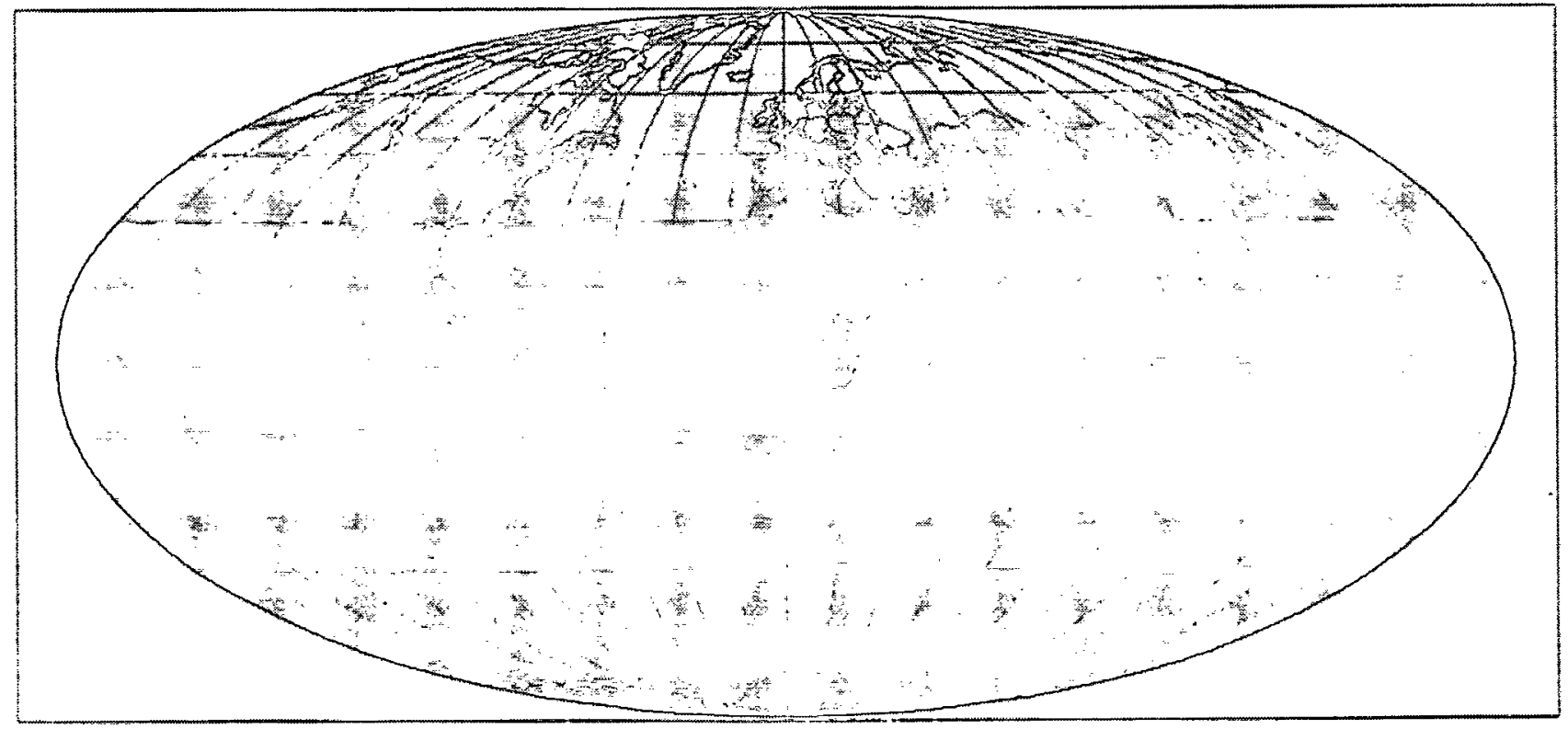

Figure 21d. October 1997 average solar radiation on horizontal surface (downward energy flux at Earth's surface) (based on NCEP/NCAR, 1998; scale given in Figure 21e). 


Energy flow
W/m2
440 to 480
400 to 440
360 to 400
320 to 360
280 to 320
240 to 280
200 to 240
160 to 200
120 to 160
80 to 120
40 to 80
0 to 40

Figure 21e. Scale used for solar radiation $\left(\mathrm{W} / \mathrm{m}^{2}\right)$.

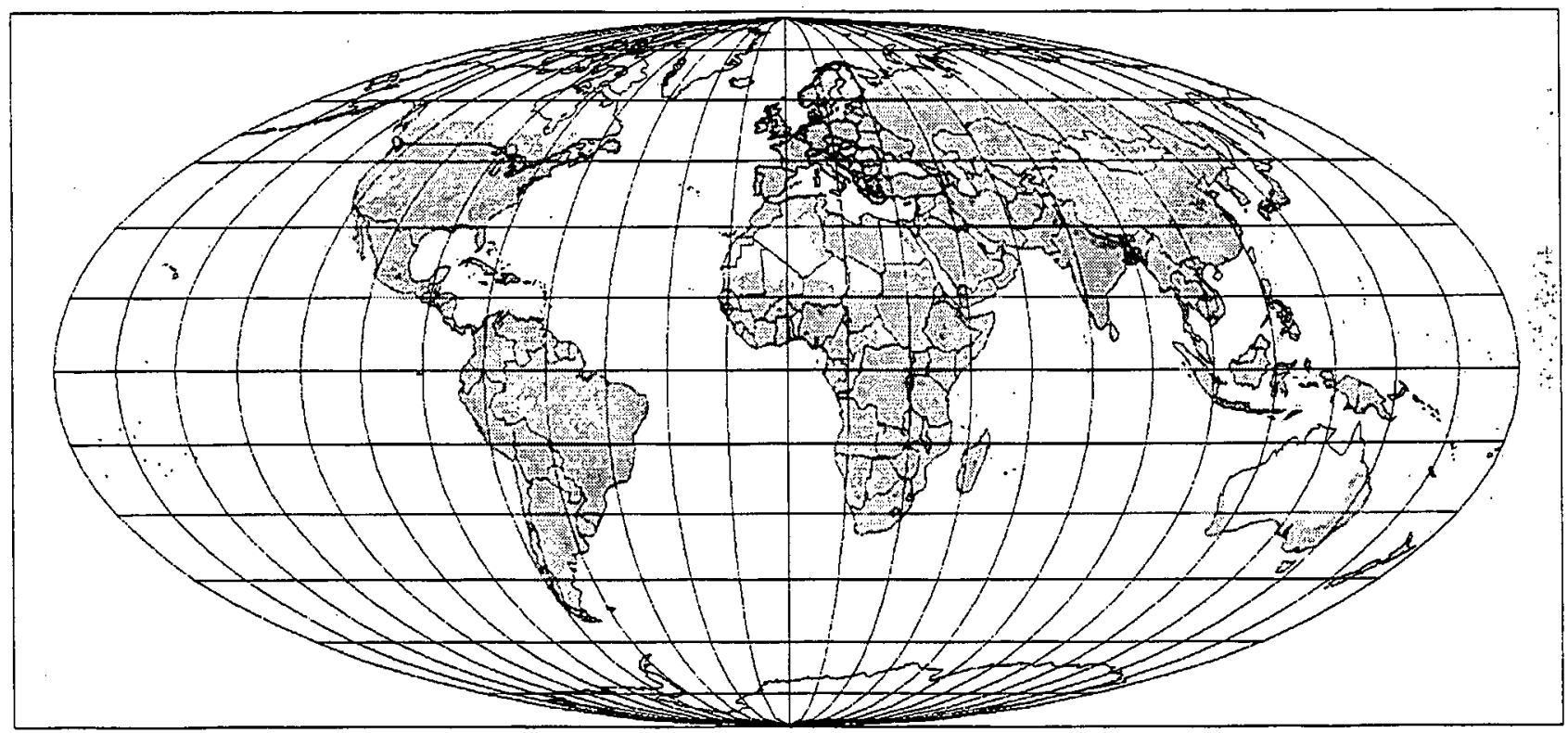

Figure 22a. January potential power production from building-integrated solar cells, with transmission and storage cycle losses subtracted (scale given in Figure 4e). 


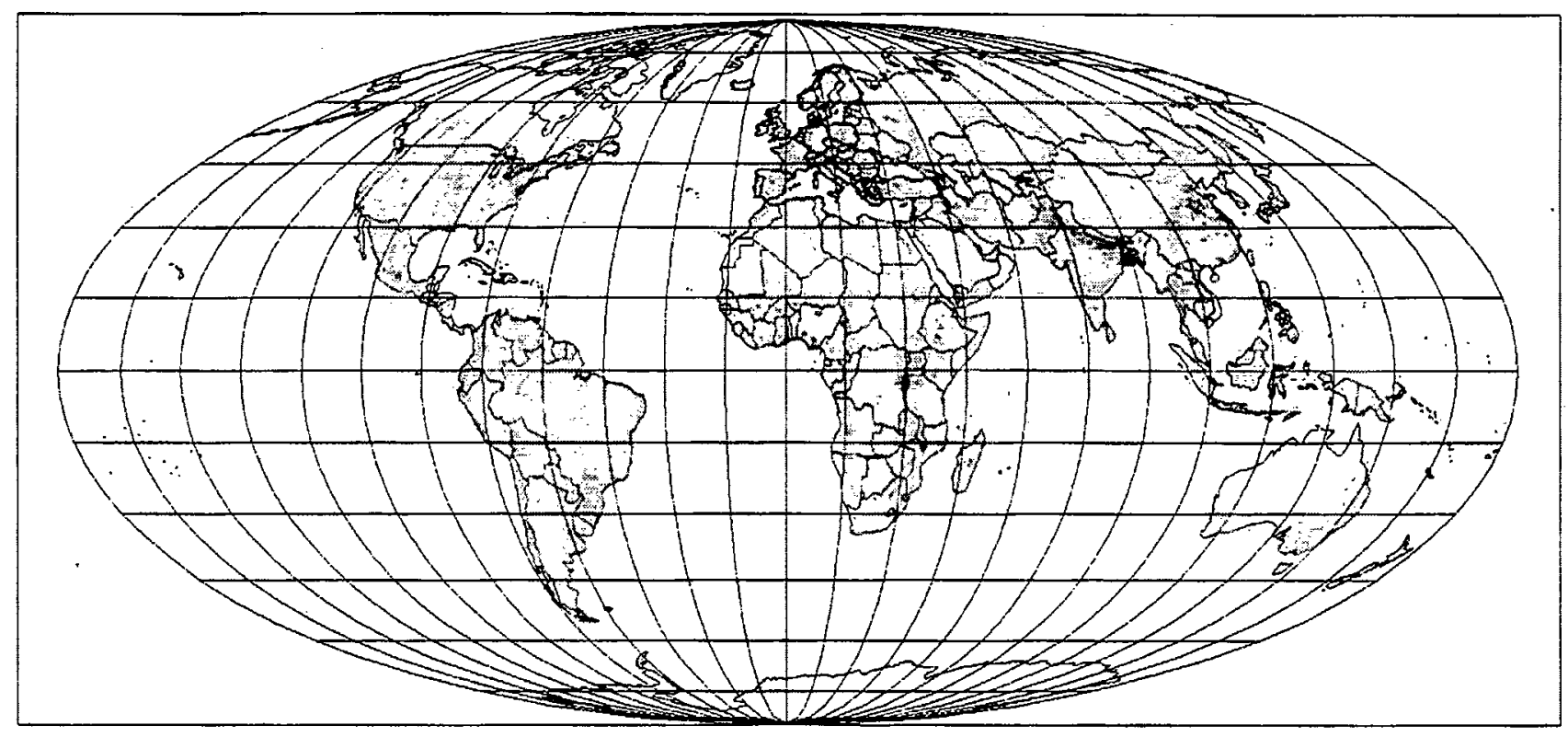

Figure 22b. April and October potential power production from building-integrated solar cells, with transmission and storage cycle losses subtracted (plain average of January and July values; scale given in Figure 4e).

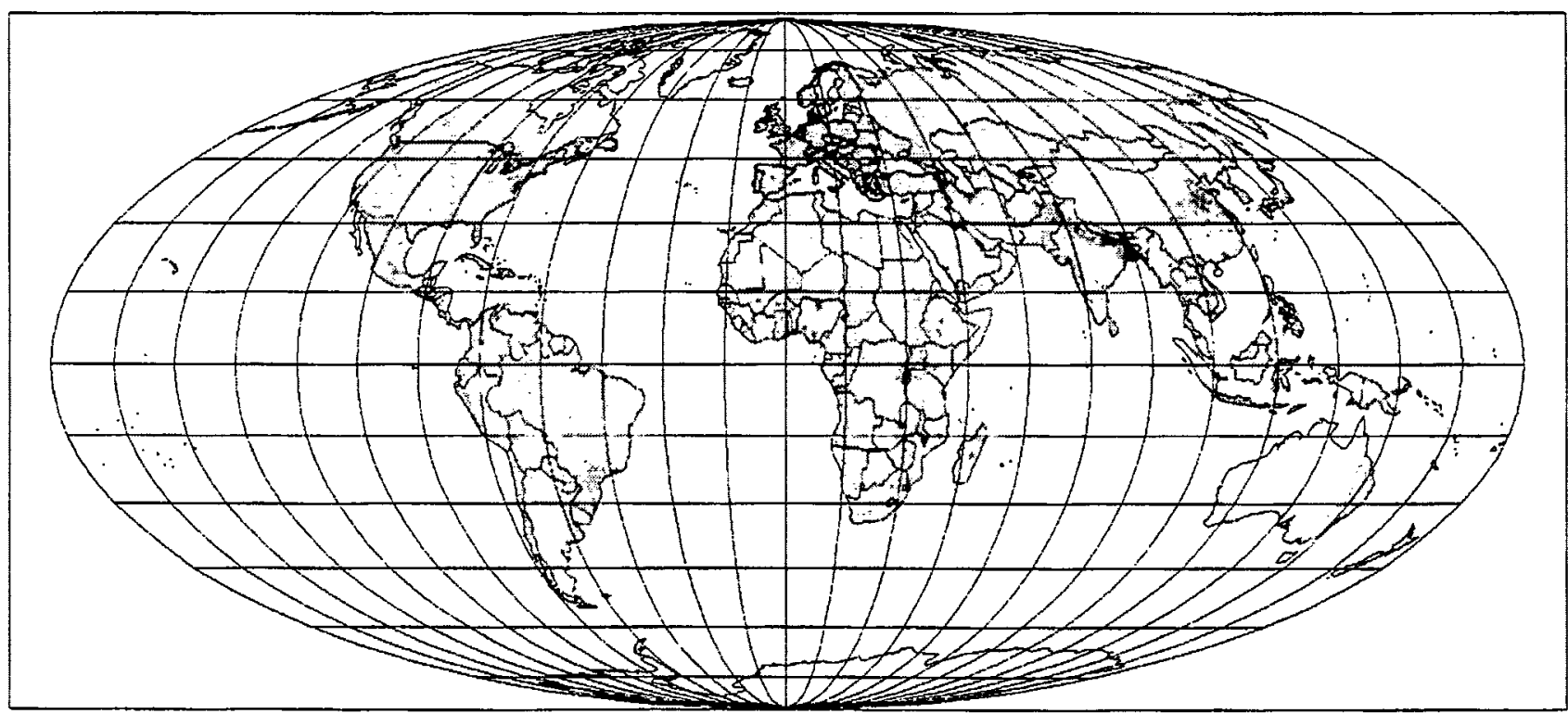

Figure 22c. July potential power production from building-integrated solar cells, with transmission and storage cycle losses subtracted (scale given in Figure 4e). 


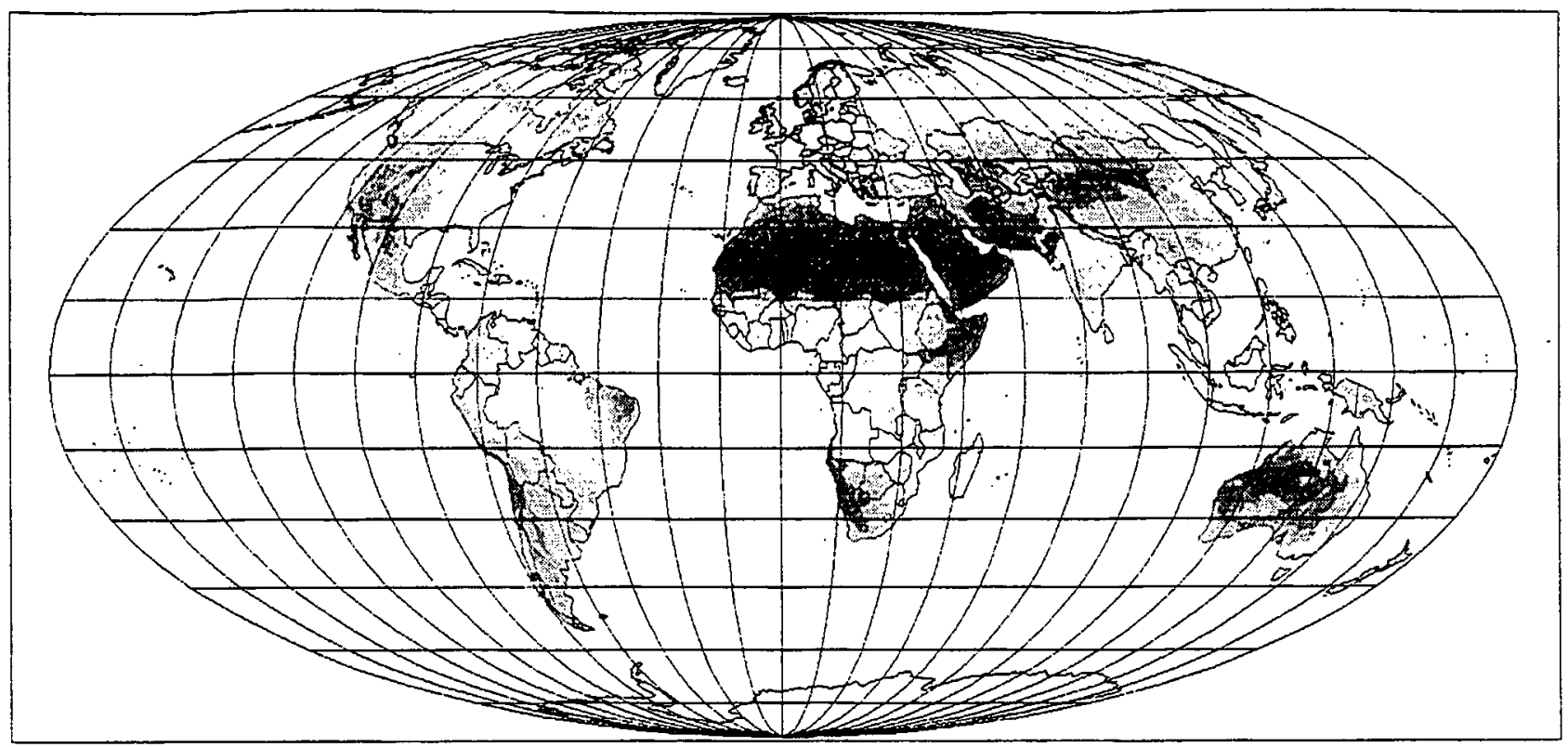

Figure 23a. Potential annual average power production from centralised photovoltaic plants on marginal land, with transmission and storage cycle losses subtracted. Seasonal variations are modest (scale given in Figure 23b).

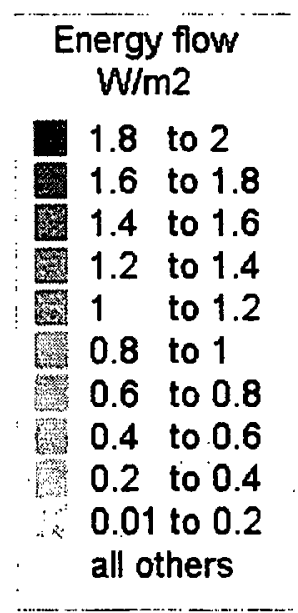

Figure 23b. Scale used for centralised photovoltaic production. Note that the scale is linear in contrast to the one used for decentralised power, e.g. in Figure $22\left(\mathrm{~W} / \mathrm{m}^{2}\right)$. 


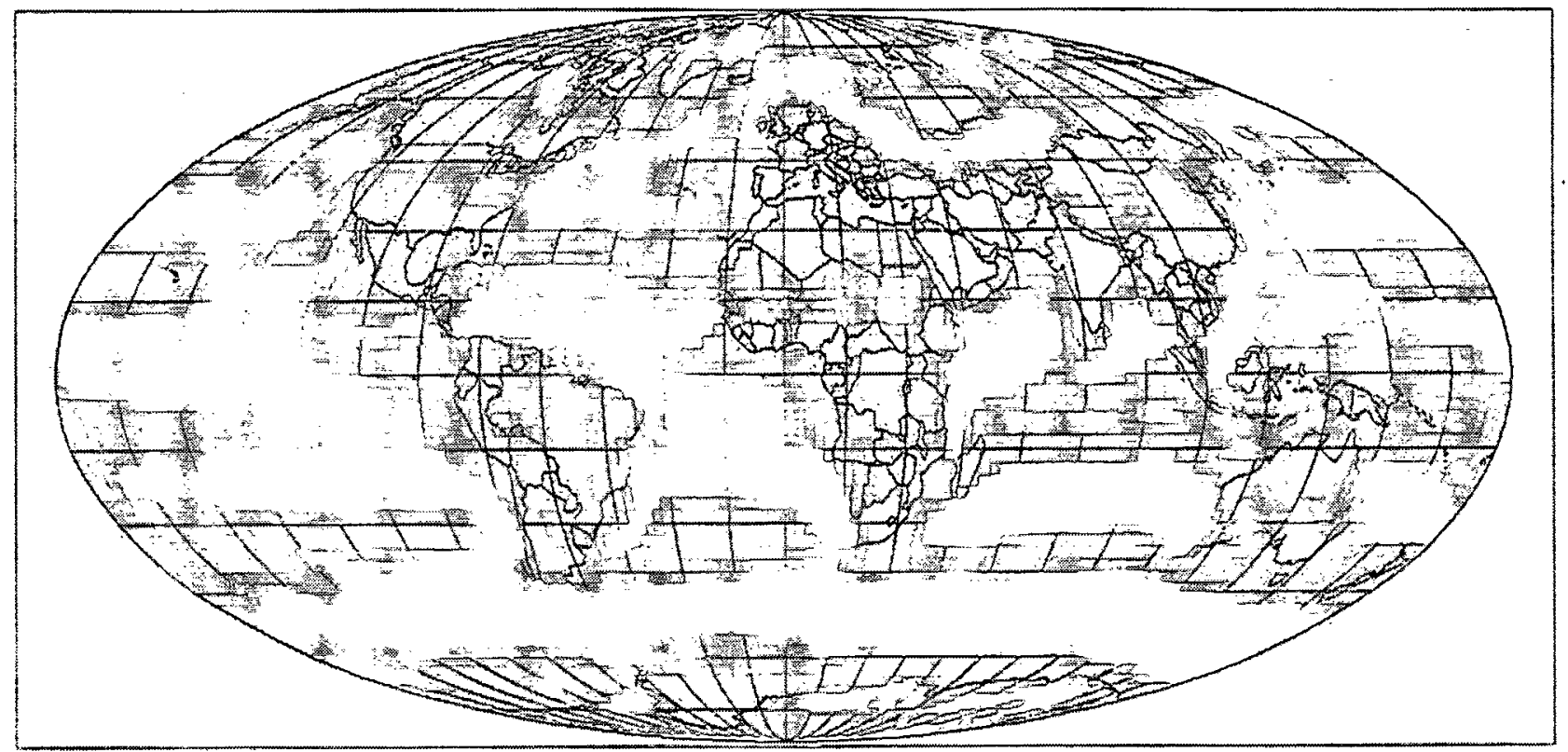

Figure 24a. Average January 1997 power in the wind at typical wind turbine hub height (about $70 \mathrm{~m}$; based on the average of $1000 \mathrm{mb}$ and $925 \mathrm{mb}$ horizontal winds from NCEP/NCAR, 1998) (scale given in Figure 24e).

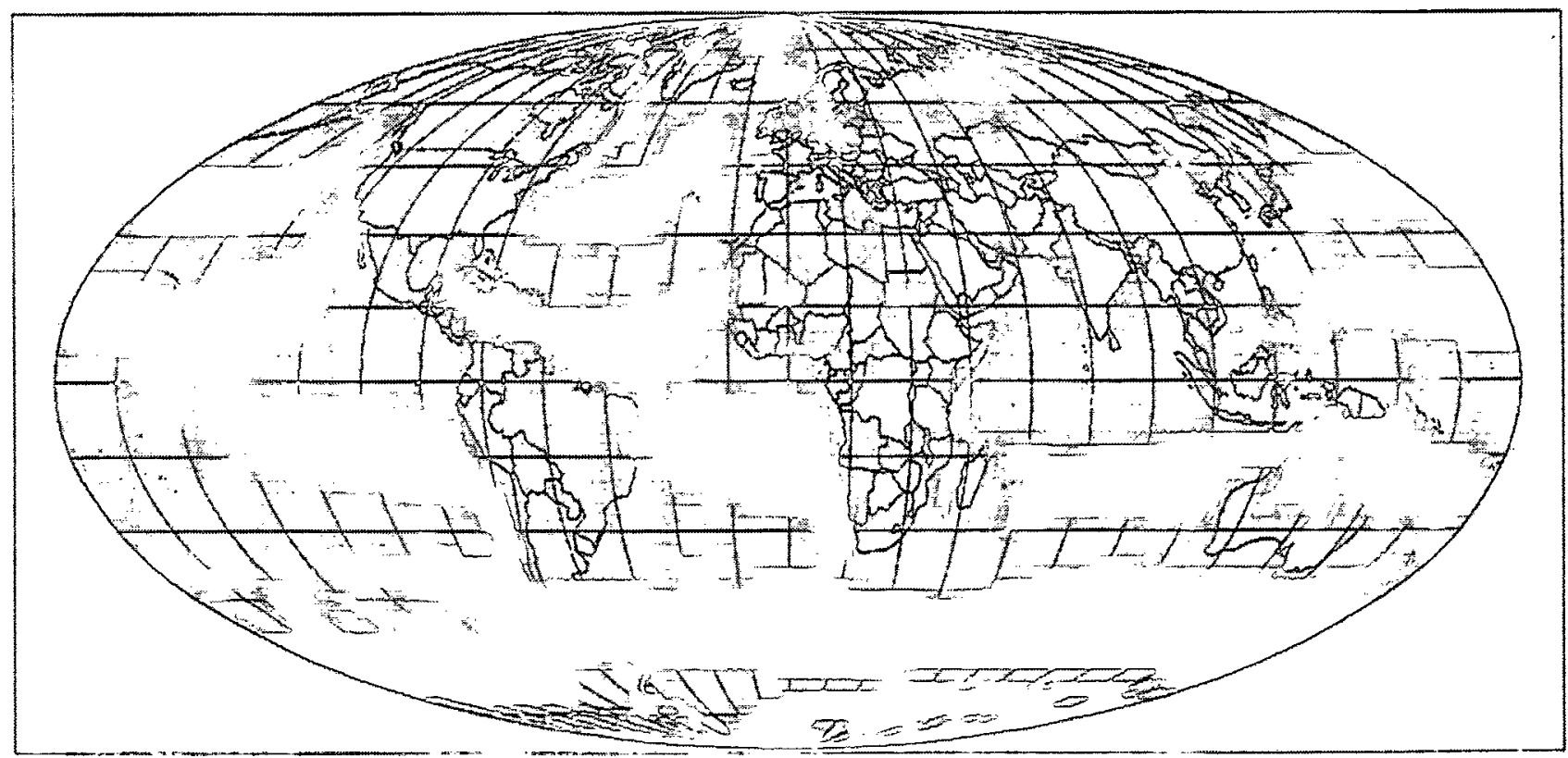

Figure 24b. Average April 1997 power in the wind at typical wind turbine hub height (about 70m; based on the average of $1000 \mathrm{mb}$ and $925 \mathrm{mb}$ horizontal winds from NCEP/NCAR, 1998) (scale given in Figure 24e). 


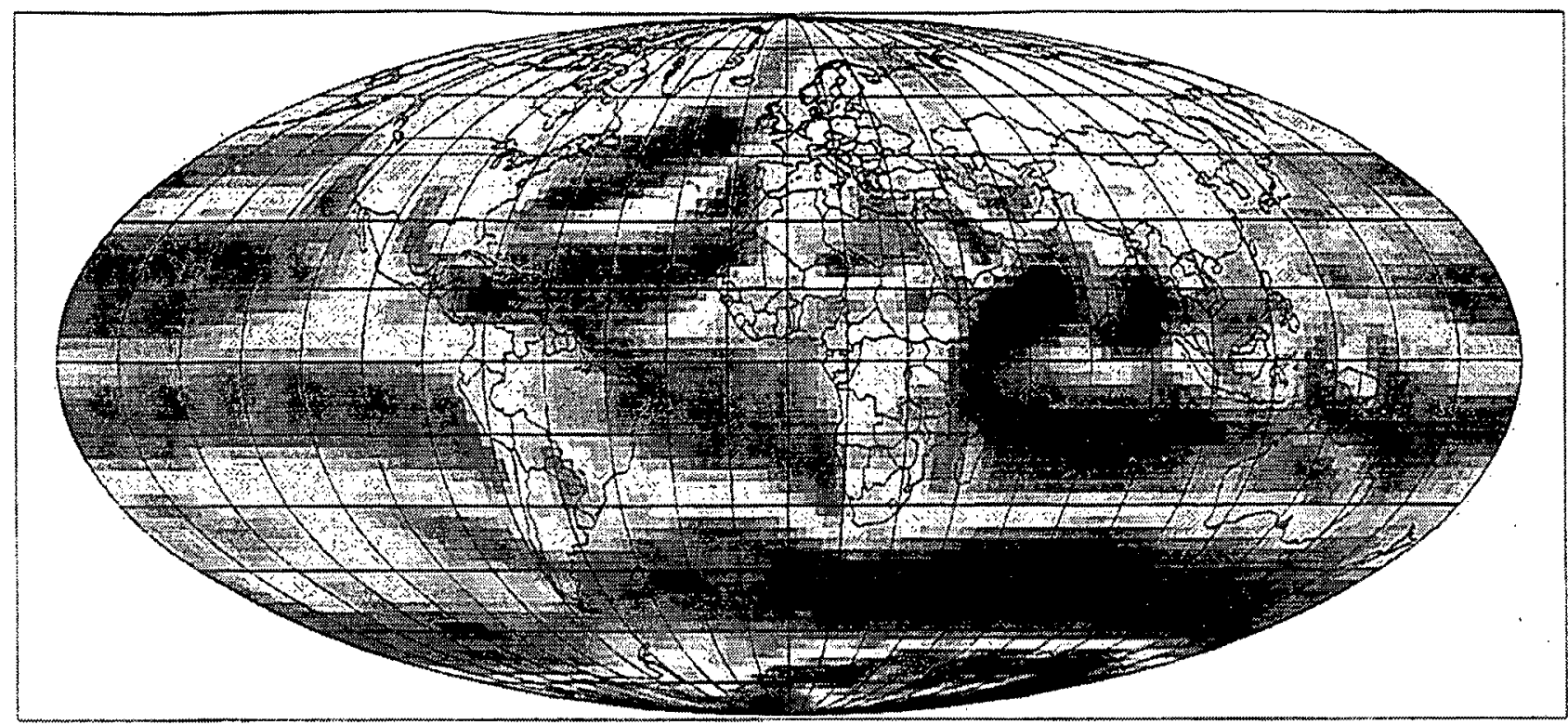

Figure 24c. Average July 1997 power in the wind at typical wind turbine hub height (about 70m; based on the average of $1000 \mathrm{mb}$ and $925 \mathrm{mb}$ horizontal winds from NCEP/NCAR, 1998) (scale given in Figure 24e).

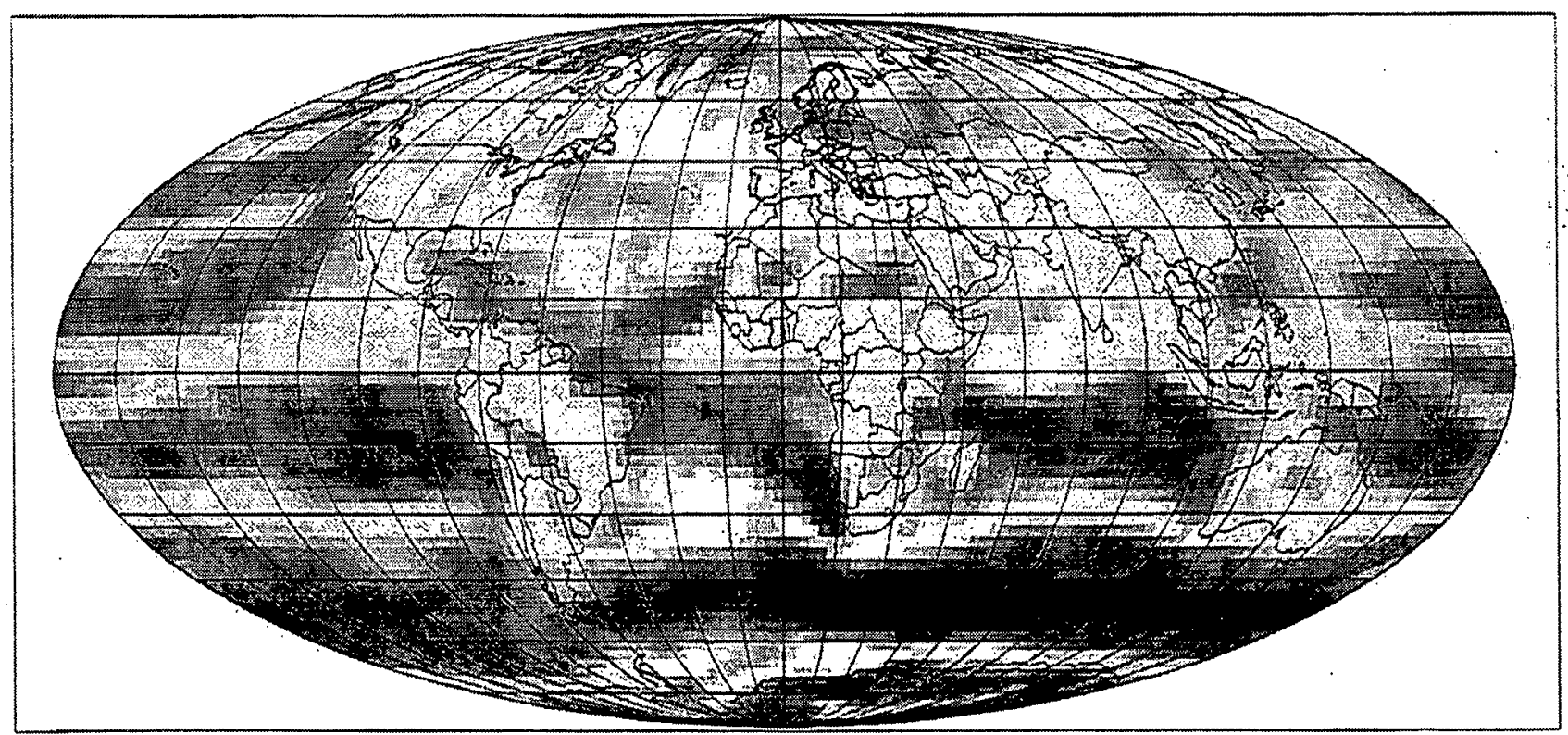

Figure 24d. Average October 1997 power in the wind at typical wind turbine hub height (about $70 \mathrm{~m}$; based on the average of $1000 \mathrm{mb}$ and $925 \mathrm{mb}$ horizontal winds from NCEP/NCAR, 1998) (scale given in Figure 24e). 


Energy flow
W/m2
1600 to 6000
800 to 1600
600 to 800
400 to 600
300 to 400
250 to 300
200 to 250
160 to 200
120 to 160
80 to 120
40 to 80
0 to 40

Figure 24e. Scale used for power in the wind $\left(\mathrm{W} / \mathrm{m}^{2}\right)$.

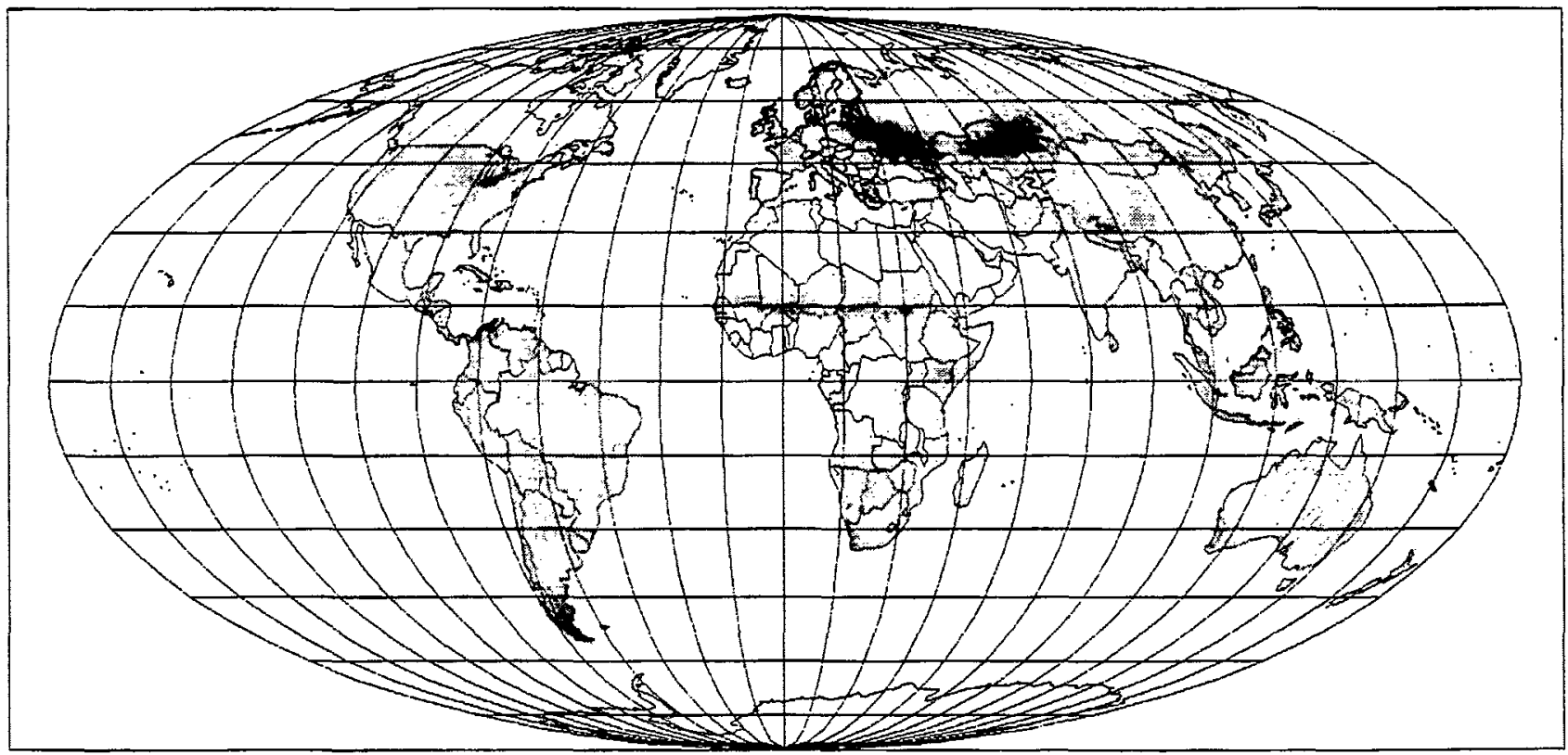

Figure 25a. Potential January average power production from decentralised wind turbine plants near farms, with transmission and storage cycle losses subtracted (scale given in Figure 4e). 


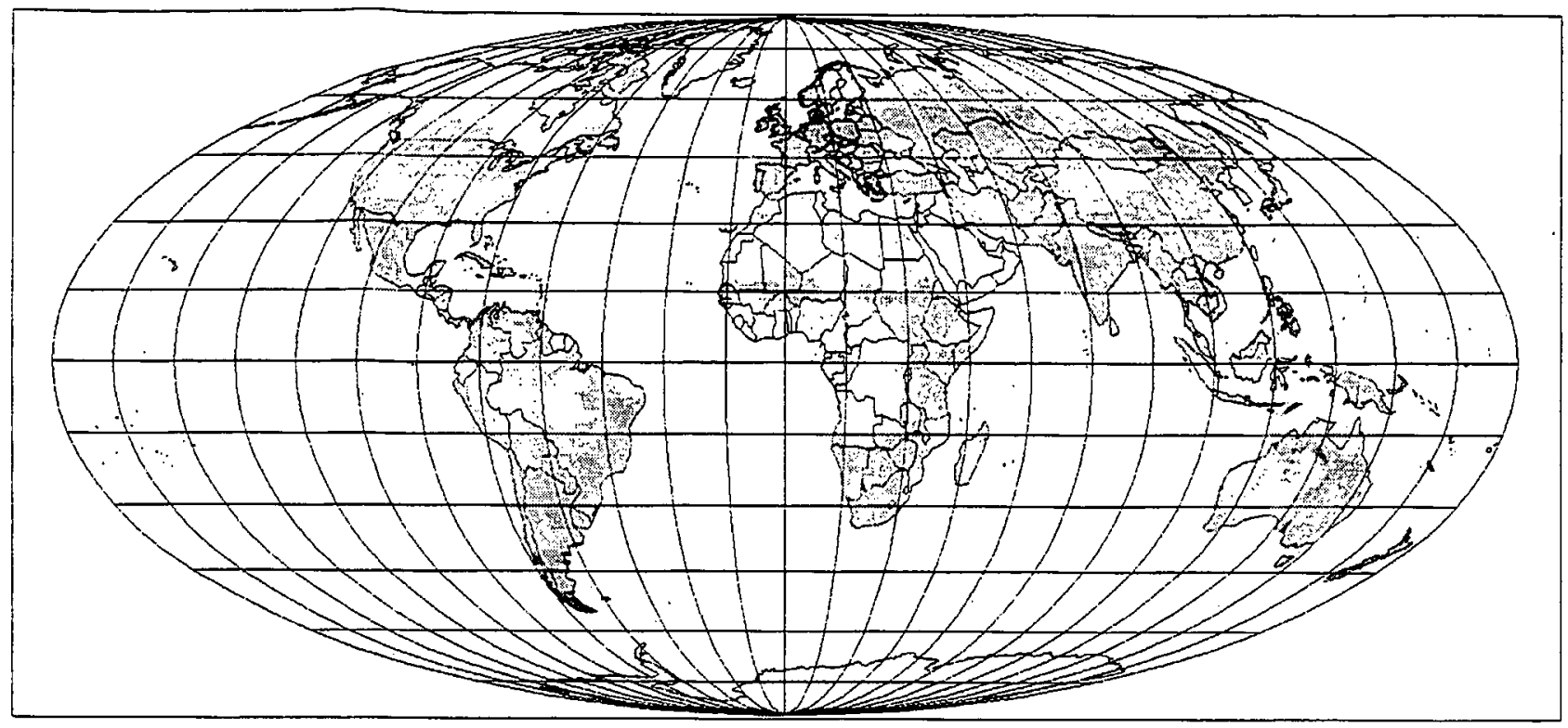

Figure 25b. Potential April average power production from decentralised wind turbine plants near farms, with transmission and storage cycle losses subtracted (scale given in Figure 4e).

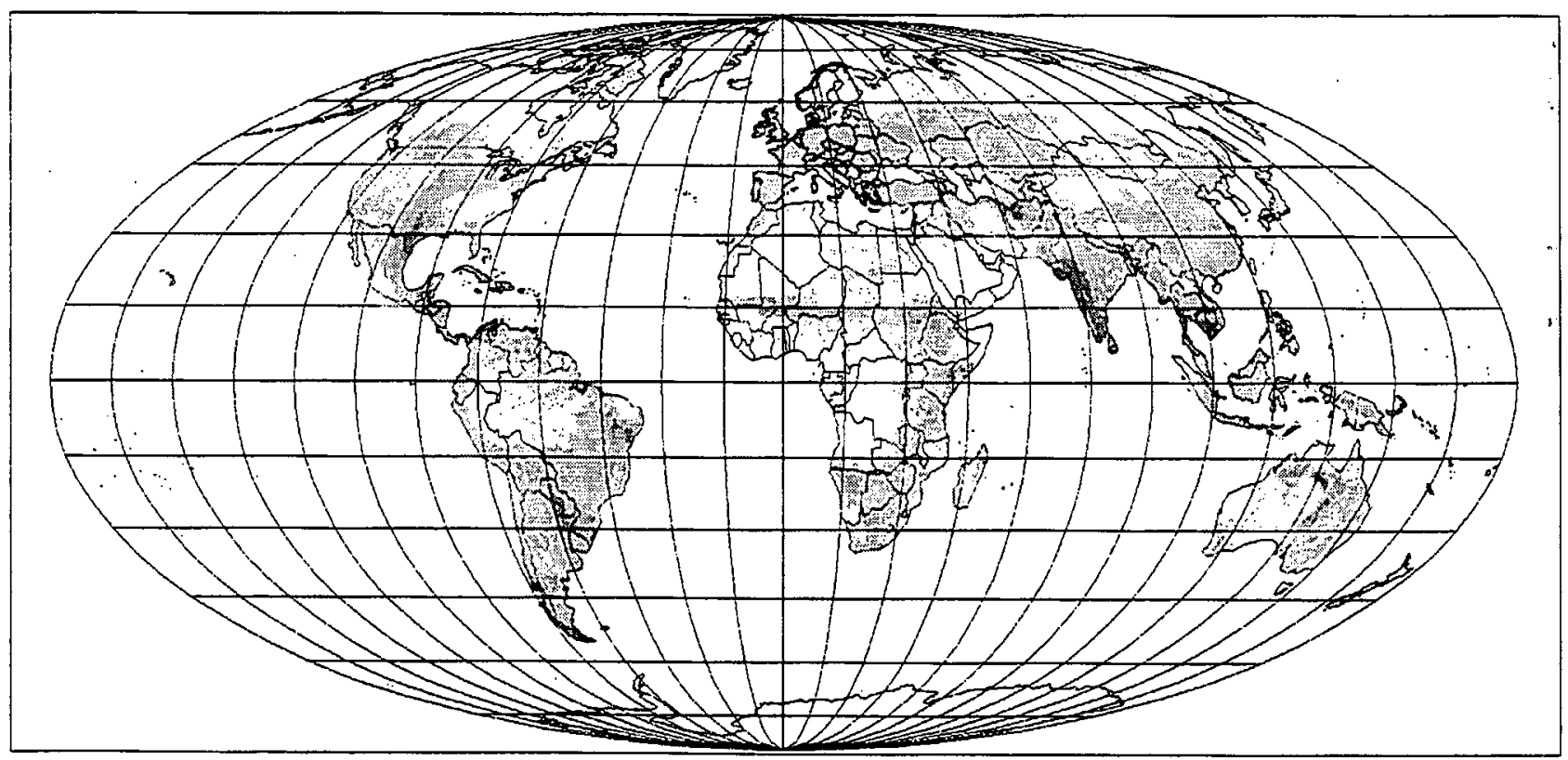

Figure 25c. Potential July average power production from decentralised wind turbine plants near farms, with transmission and storage cycle losses subtracted (scale given in Figure 4e). 


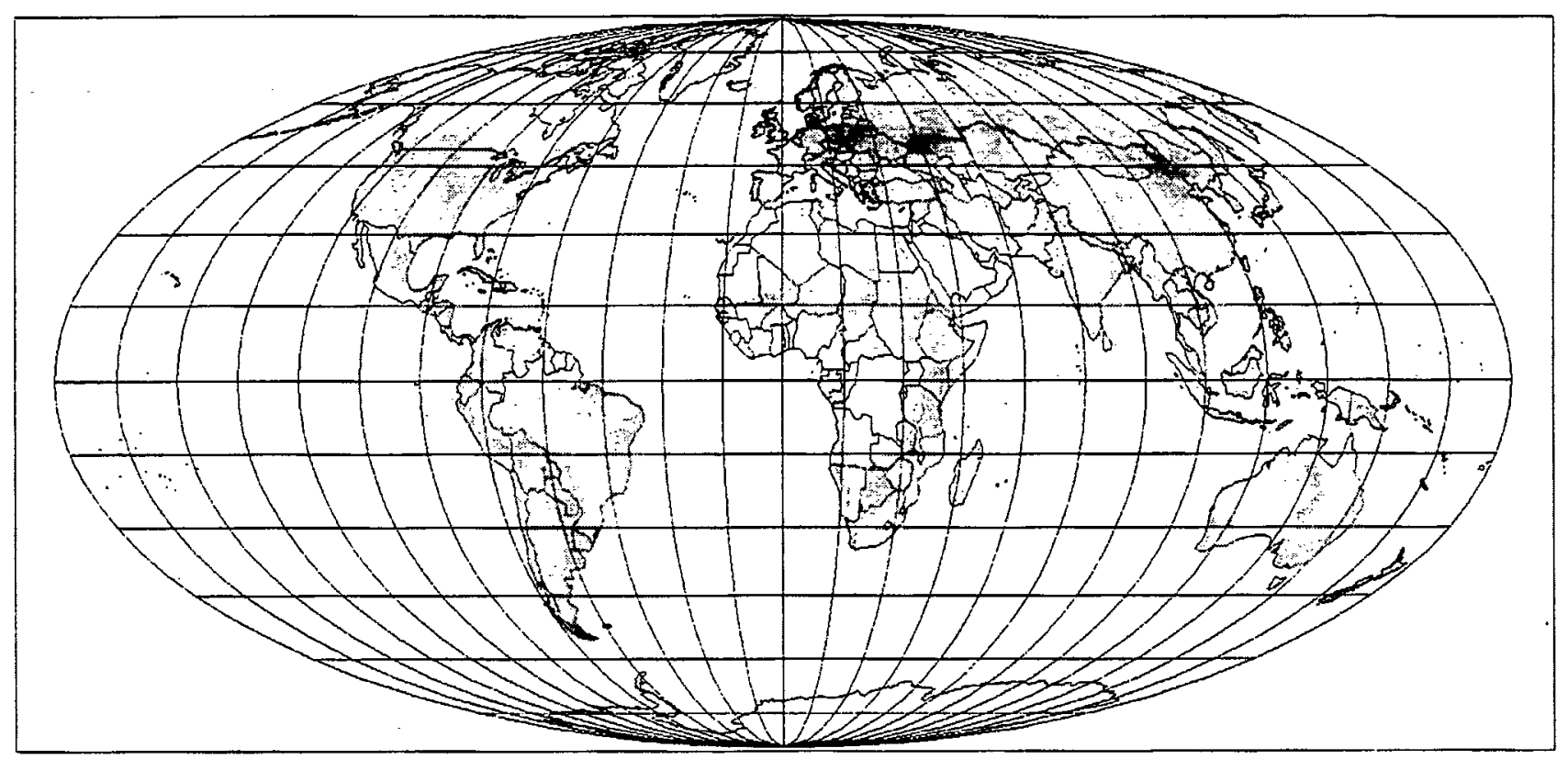

Figure 25d. Potential October average power production from decentralised wind turbine plants near farms, with transmission and storage cycle losses subtracted (scale given in Figure $4 \mathrm{e})$.

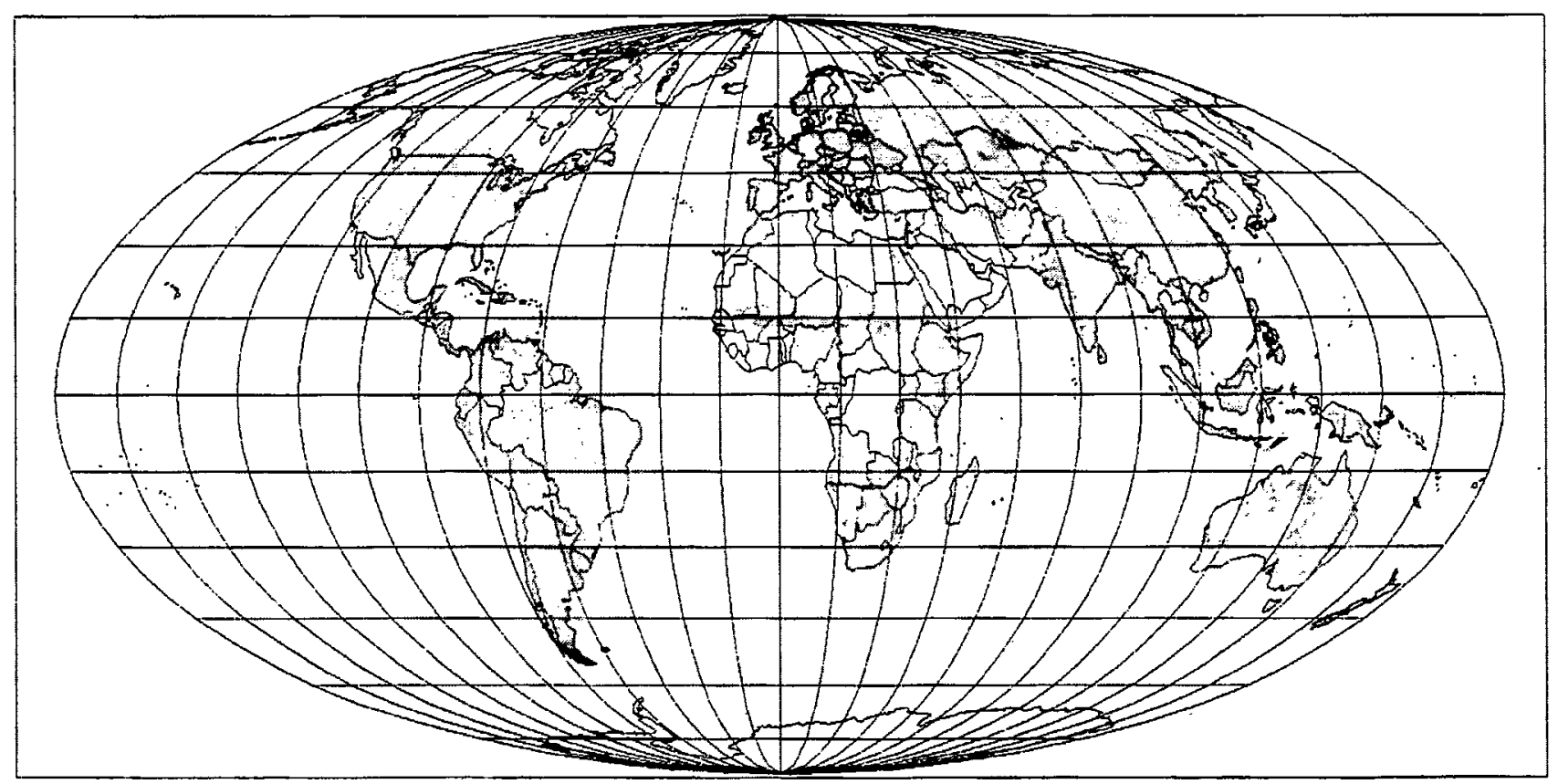

Figure 25e. Potential annual average power production from decentralised wind turbine plants near farms (on crop- and rangeland), with transmission and storage cycle losses subtracted (scale given in Figure 4e). 


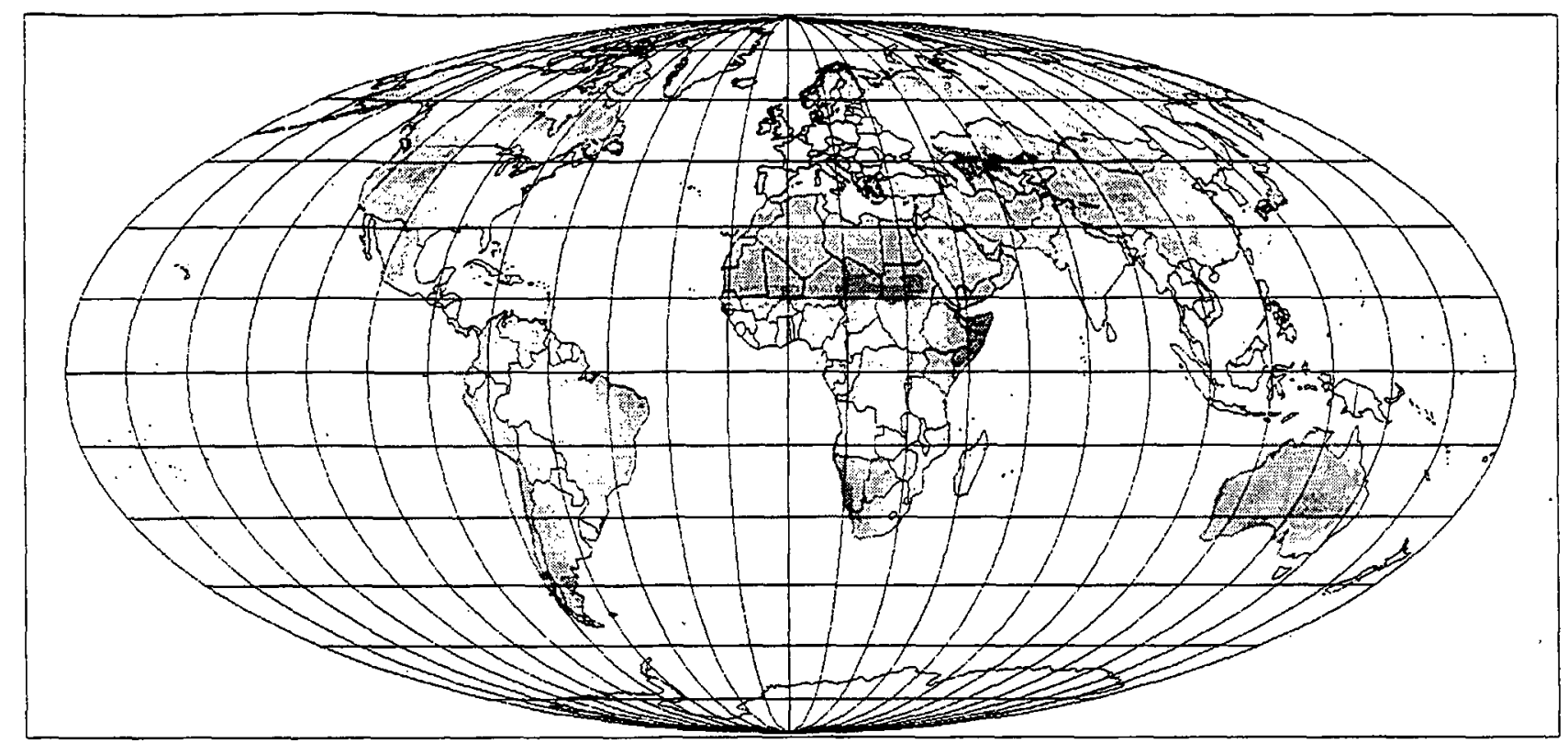

Figure 26a. Potential January average power production from centralised wind turbine parks on marginal land, with transmission and storage cycle losses subtracted (scale given in Figure $4 \mathrm{e})$.

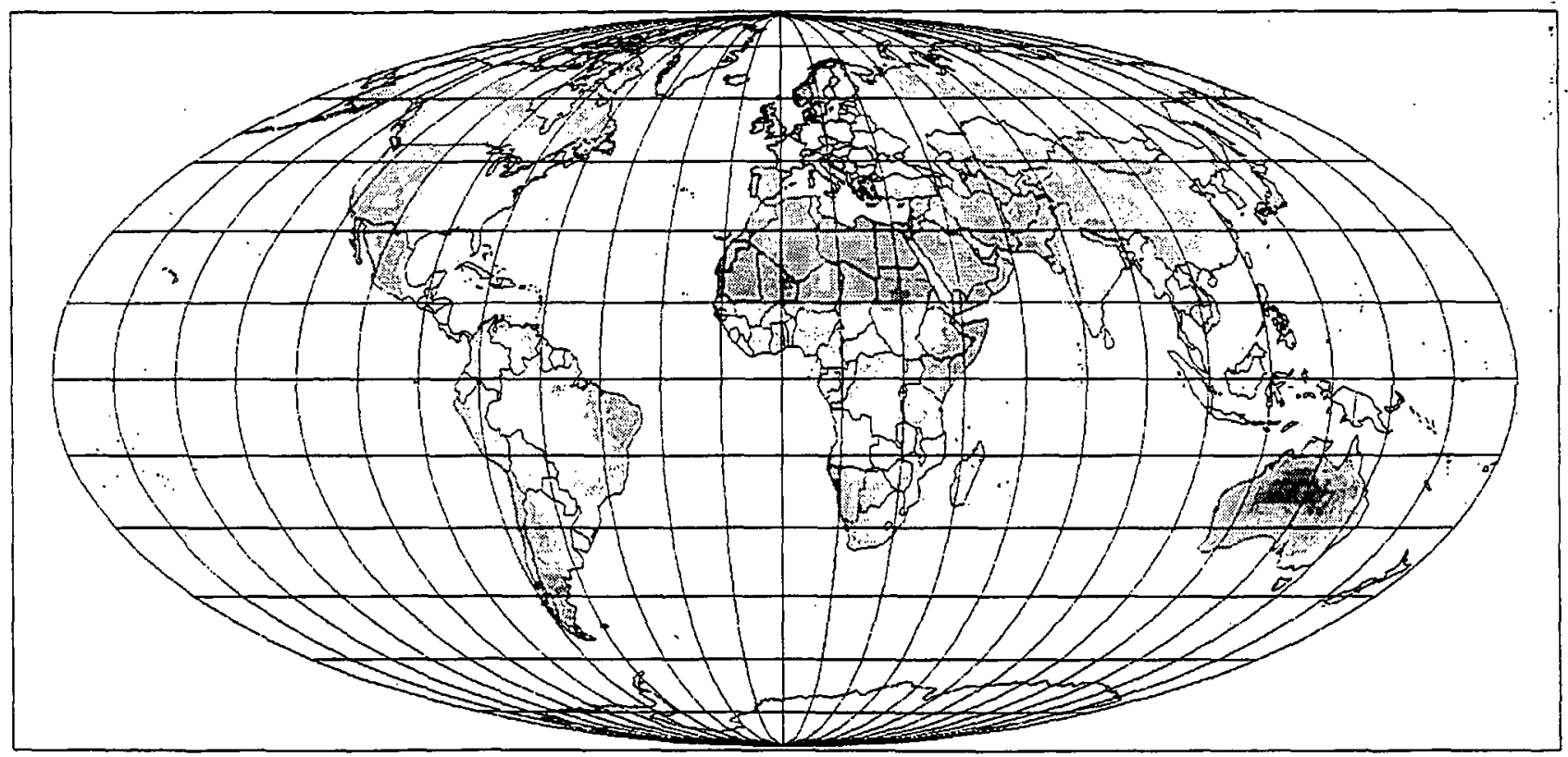

Figure 26b. Potential April average power production from centralised wind turbine parks on marginal land, with transmission and storage cycle losses subtracted (scale given in Figure 4e). 


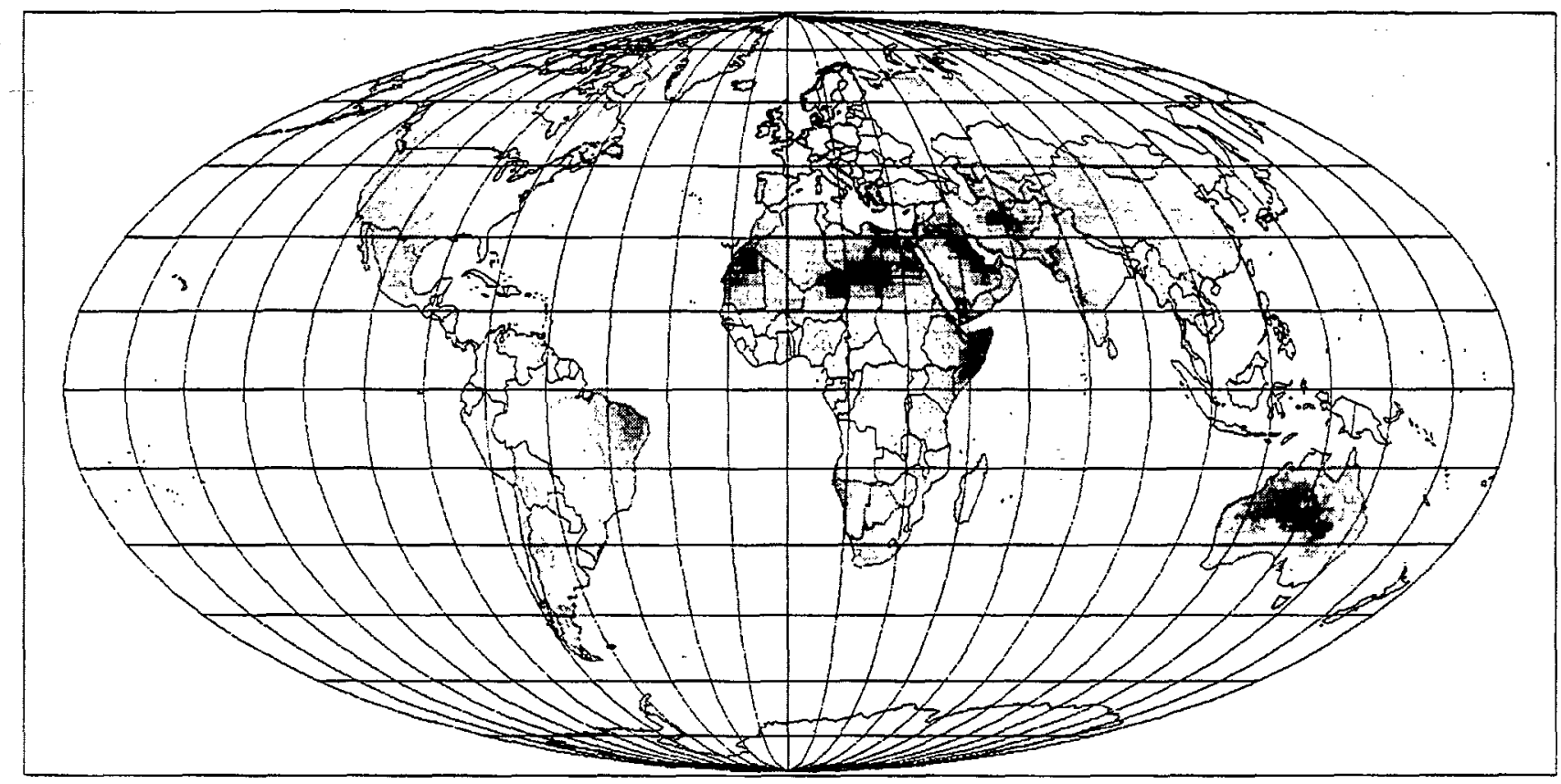

Figure 26c. Potential July average power production from centralised wind turbine parks on marginal land, with transmission and storage cycle losses subtracted (scale given in Figure 4e).

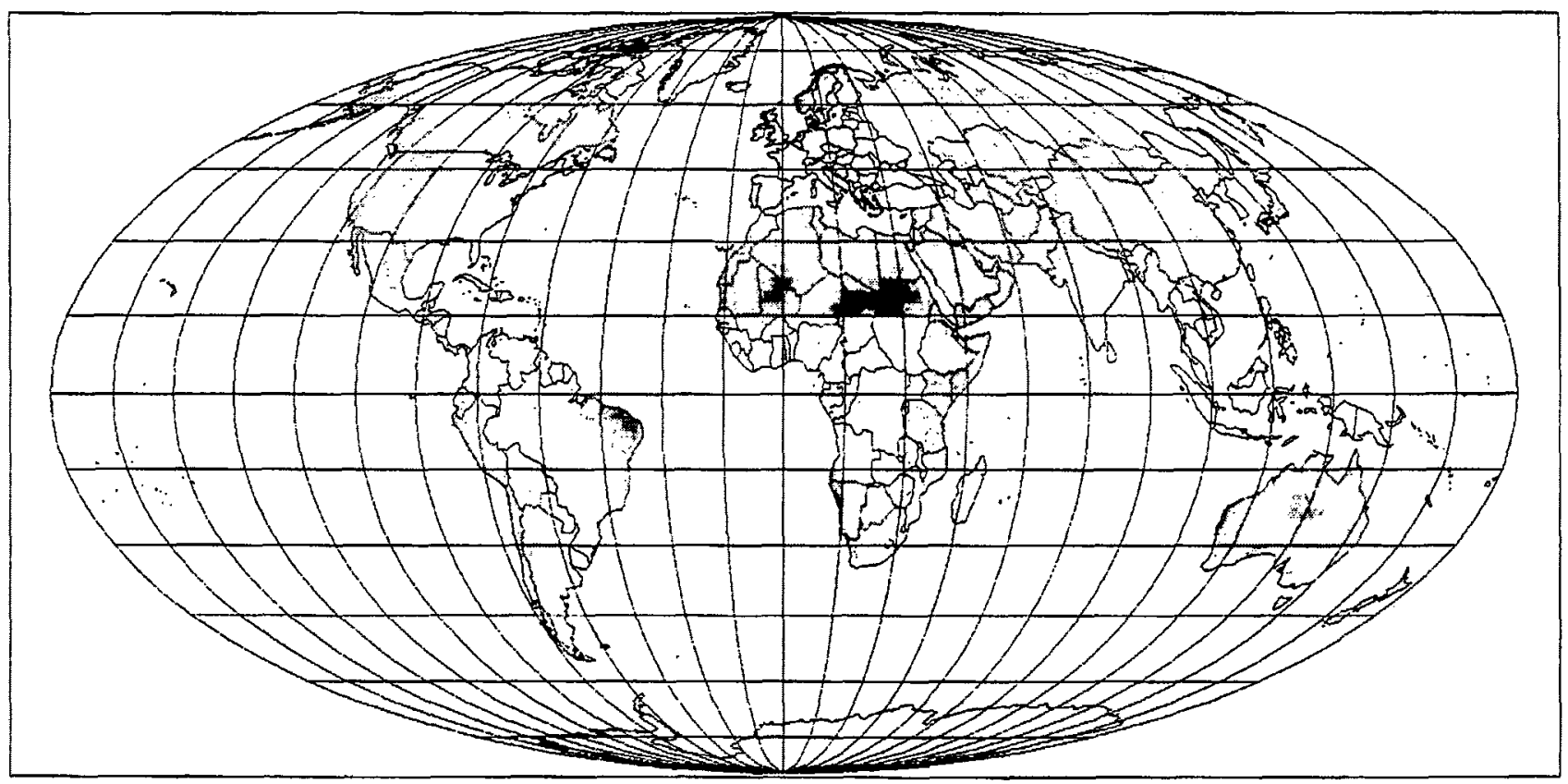

Figure 26d. Potential October average power production from centralised wind turbine parks on marginal land, with transmission and storage cycle losses subtracted (scale given in Figure $4 \mathrm{e})$. 


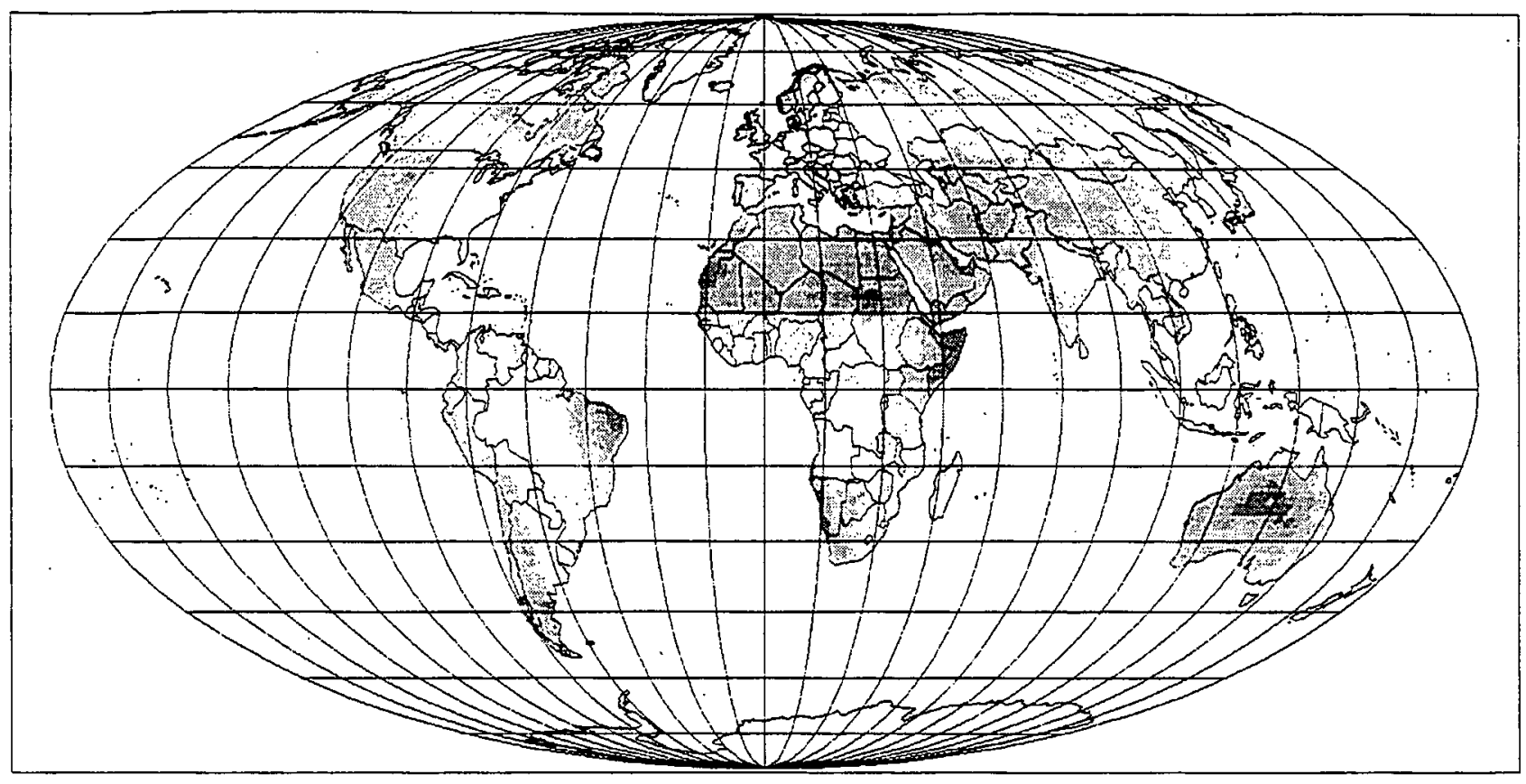

Figure 26e. Potential annual average power production from centralised wind turbine parks on marginal land, with transmission and storage cycle losses subtracted (scale given in Figure 4e).

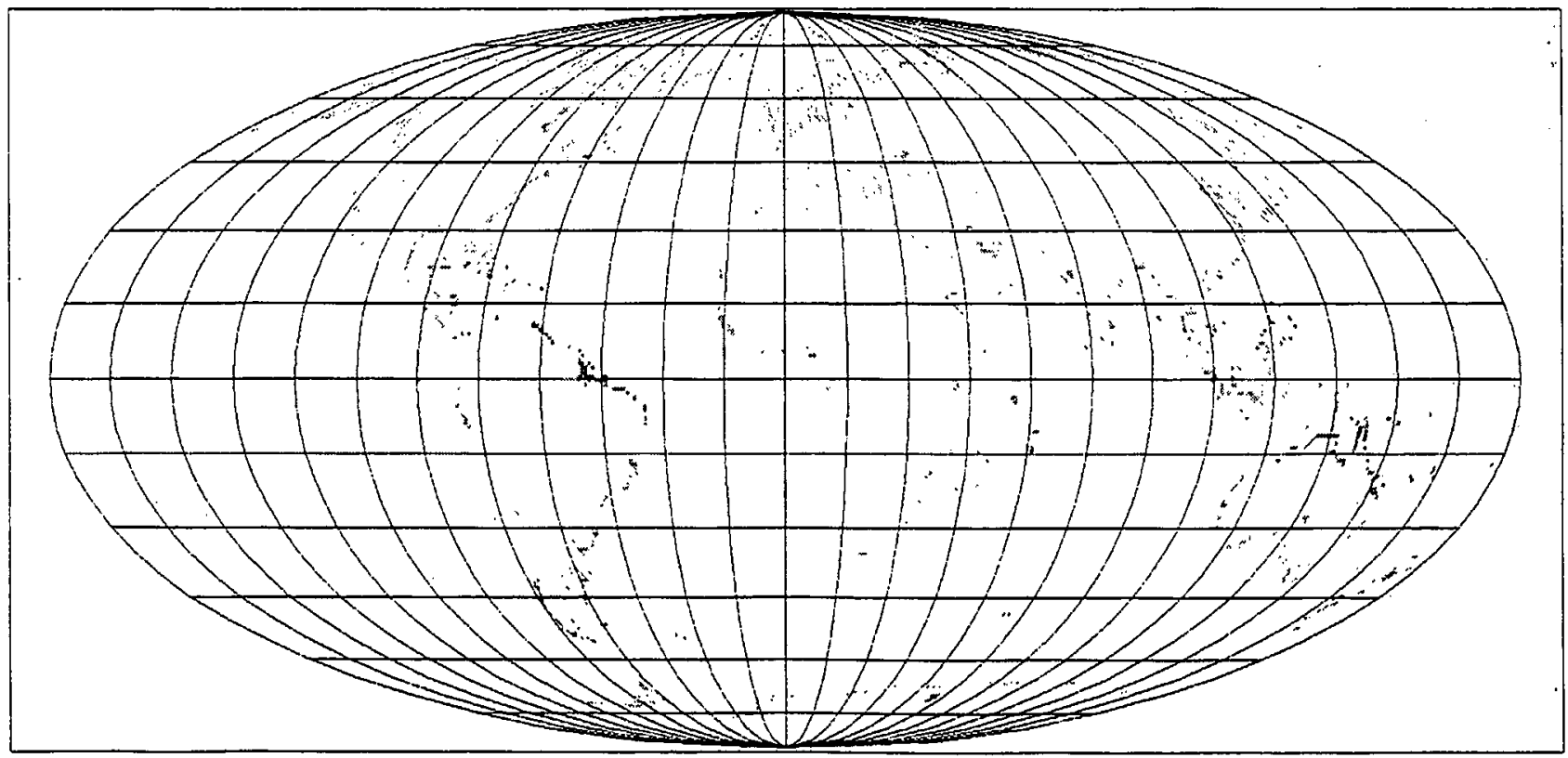

Figure 27. Potential annual average power production from centralised off-shore wind turbine parks (water depth under $20 \mathrm{~m}$ ), with transmission and storage cycle losses subtracted (scale given in Figure 4e). 


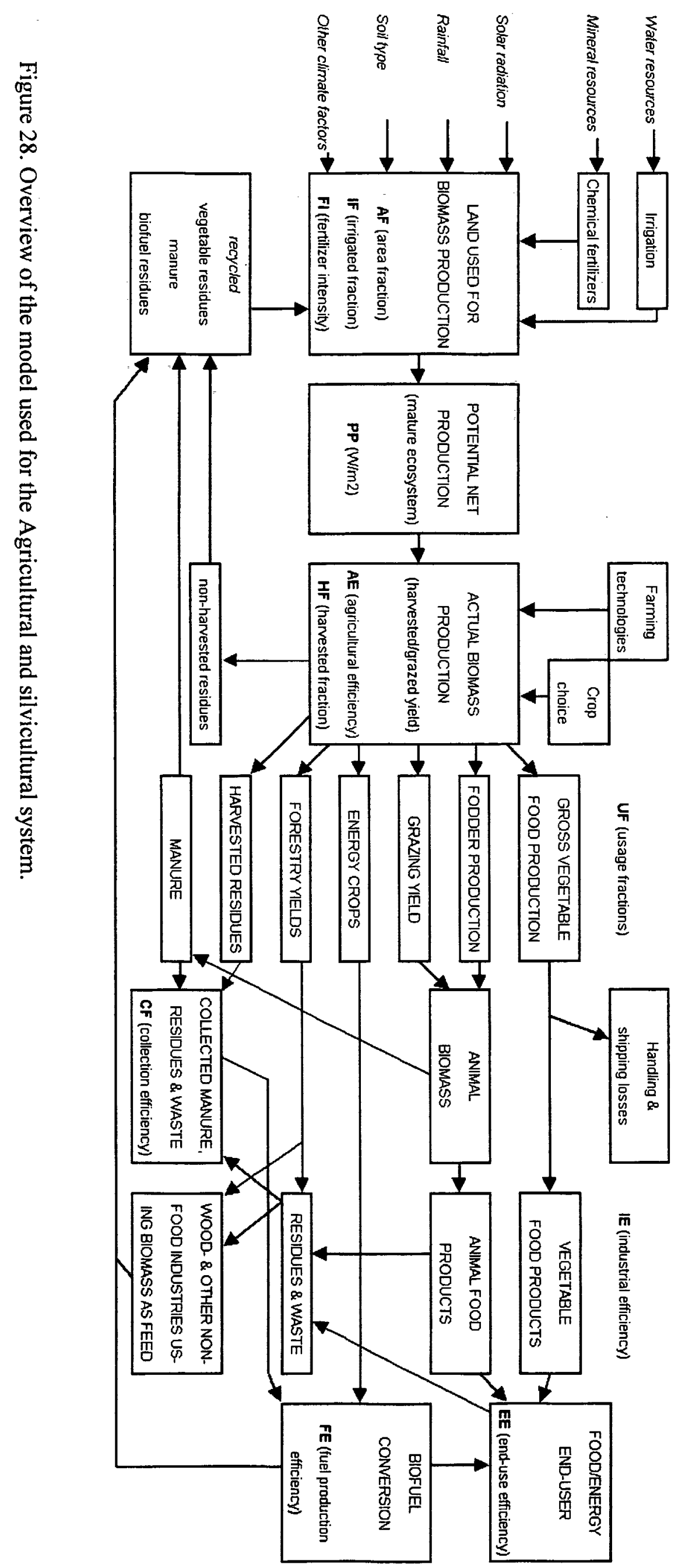




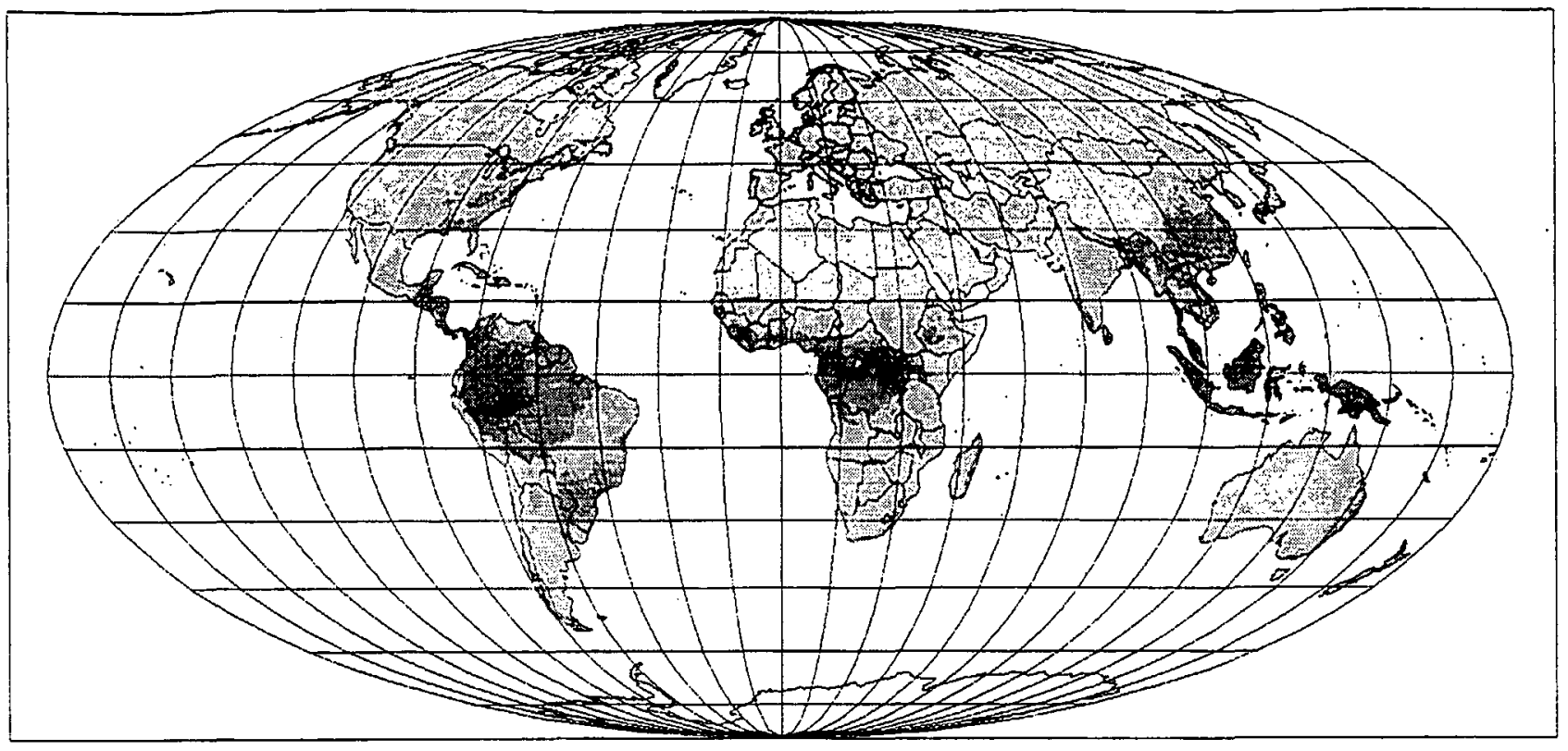

Figure 29a. Annual average energy content of potential net biomass production in mature ecosystems (based on Melillo and Helfrich, 1998; scale given in Figure 29b).

Figure $29 \mathrm{~b}$. Net primary production energy scale $\left(\mathrm{W} / \mathrm{m}^{2}\right.$, the scale is linear).

$\begin{aligned} & \text { Energy linear scale } \\ & W / \mathrm{m} 2 \\ & 2 \text { to } 2.2 \\ & 1.8 \text { to } 2 \\ & 1.6 \text { to } 1.8 \\ & 1.4 \text { to } 1.6 \\ & 1.2 \text { to } 1.4 \\ & 1 \text { to } 1.2 \\ & 0.8 \text { to } 1 \\ & 0.6 \text { to } 0.8 \\ & 0.4 \text { to } 0.6 \\ & 0.2 \text { to } 0.4 \\ & 0.01 \text { to } 0.2 \\ & \text { all others }\end{aligned}$




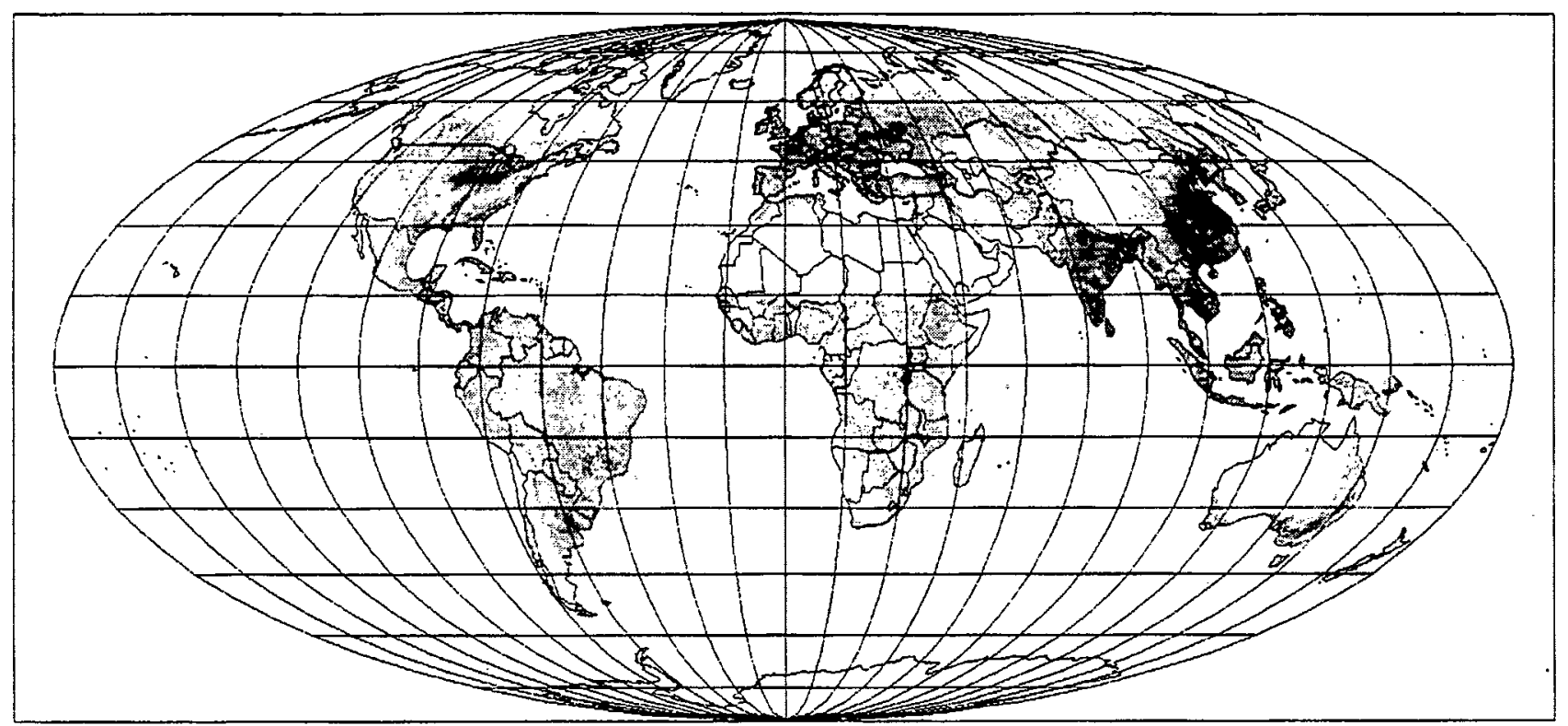

Figure 30. Potential vegetable food delivery to final consumers in 2050 scenario, derived from cropland production and expressed by annual energy content (scale given in Figure 4e).

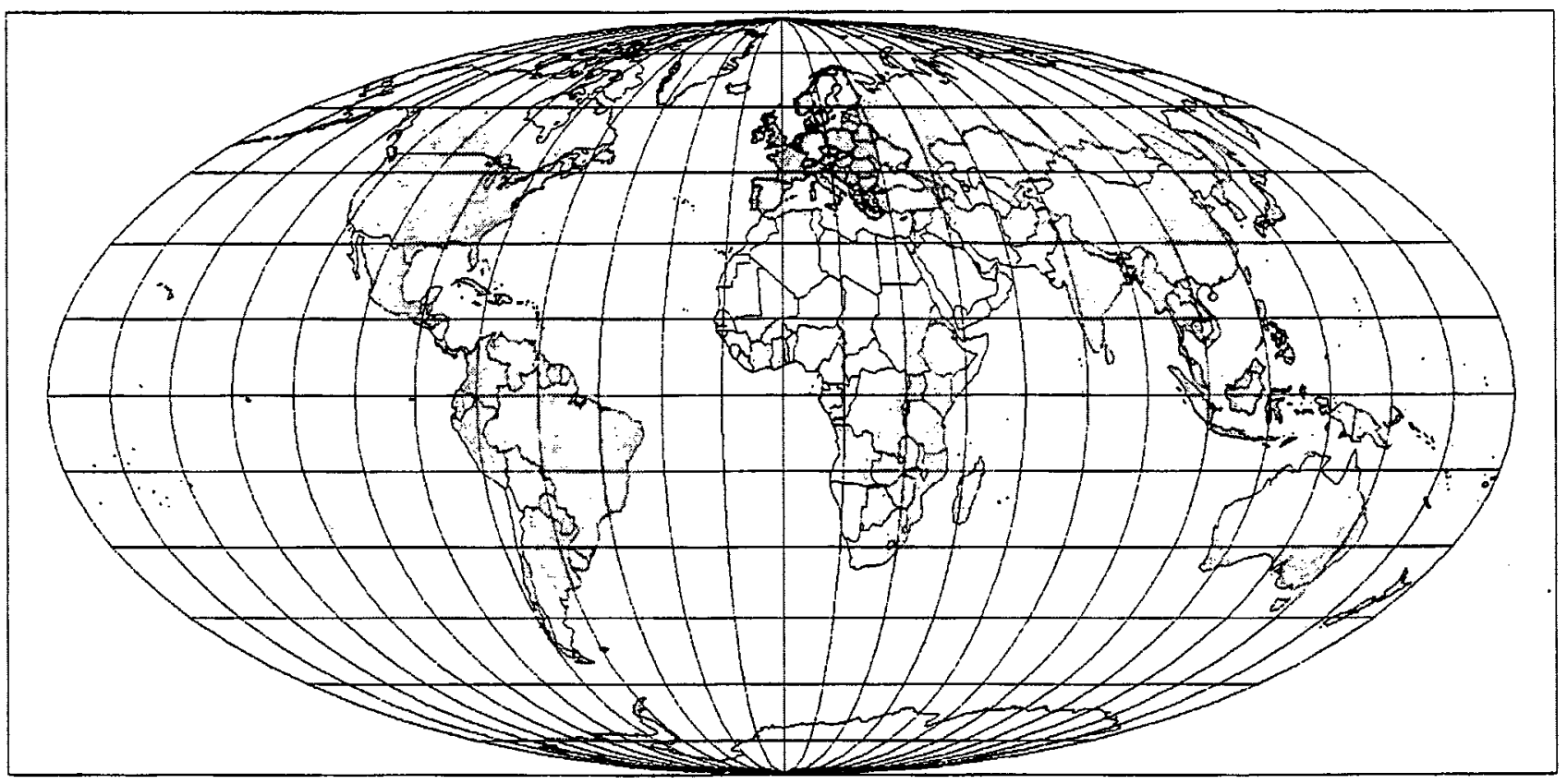

Figure 31. Potential animal food delivery to final consumers in 2050 scenario, for the fraction of animals being fed fodder grown on cropland, expressed by annual energy content (scale given in Figure 4e). 


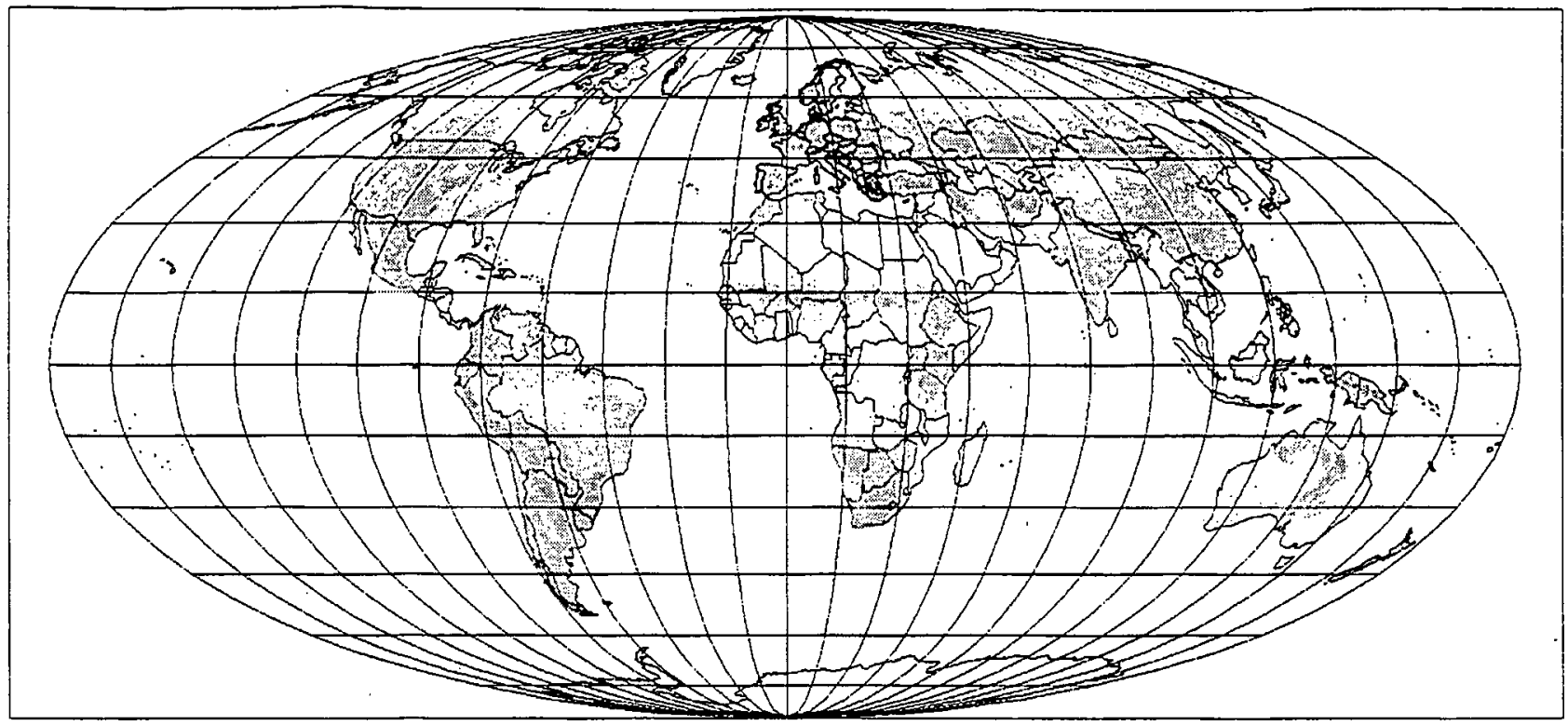

Figure 32. Potential animal food delivery to final consumers in 2050 scenario, for the fraction of animals grazing on rangeland, expressed by annual energy content (scale given in Figure 4e).

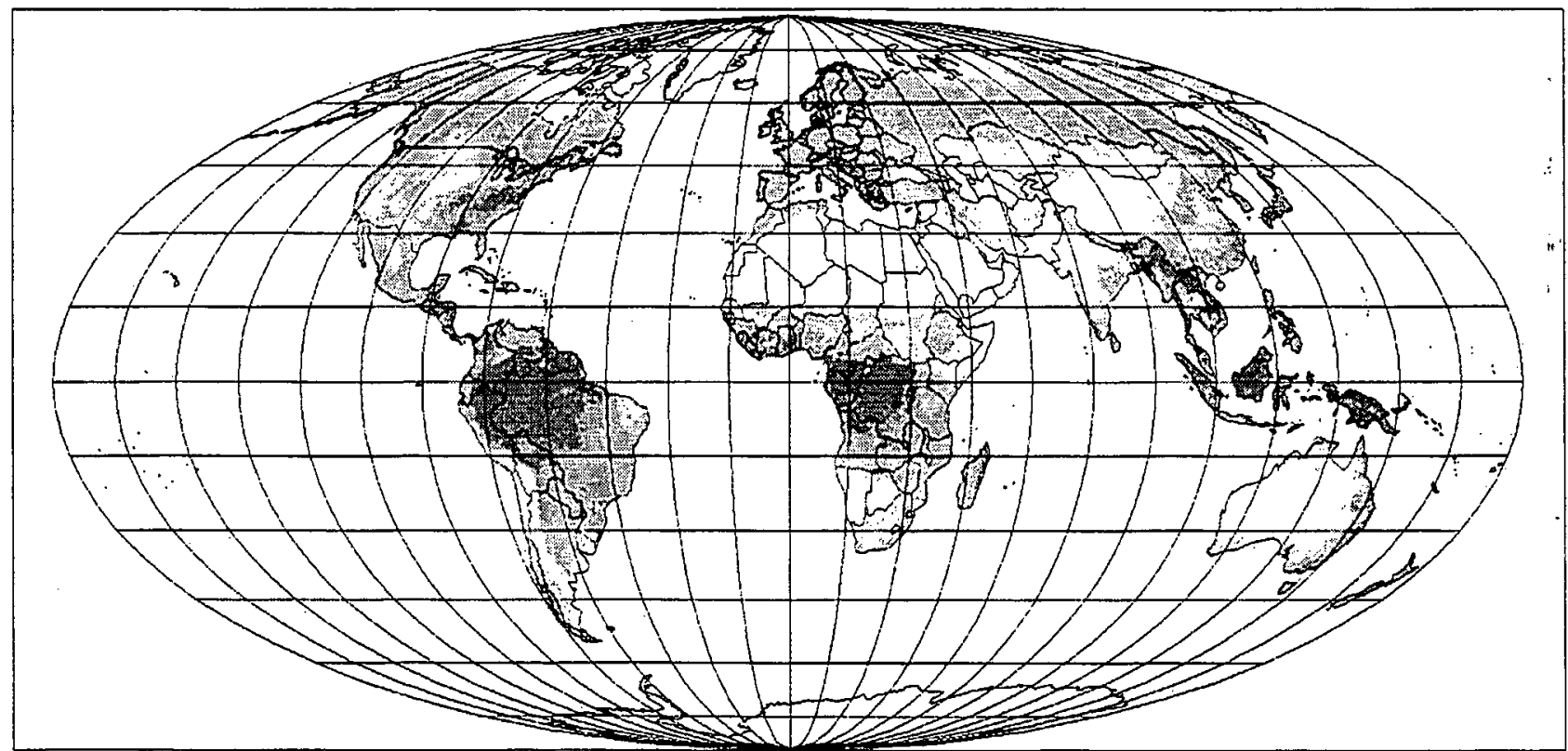

Figure 33. Potential biofuels produced and delivered to final consumers in 2050 scenario, from use of forestry residues and wood waste, expressed by annual energy content (scale given in Figure 4e). 


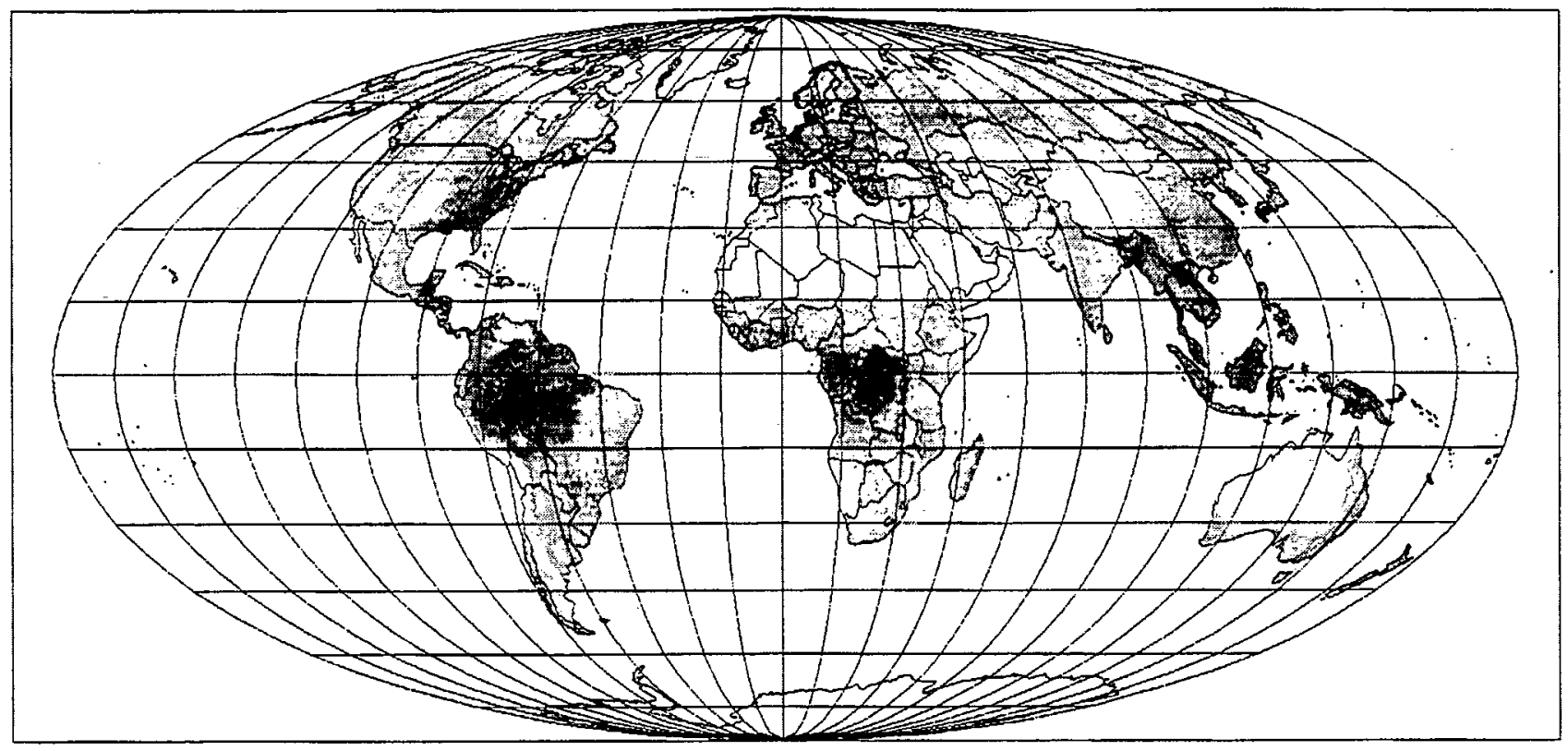

Figure 34. Potential delivery of biofuels to final consumers in 2050 scenario, from forestry (cf. Figure 33) and from agricultural residues, manure and waste from households and food industry, expressed by annual energy content (scale given in Figure 4e).

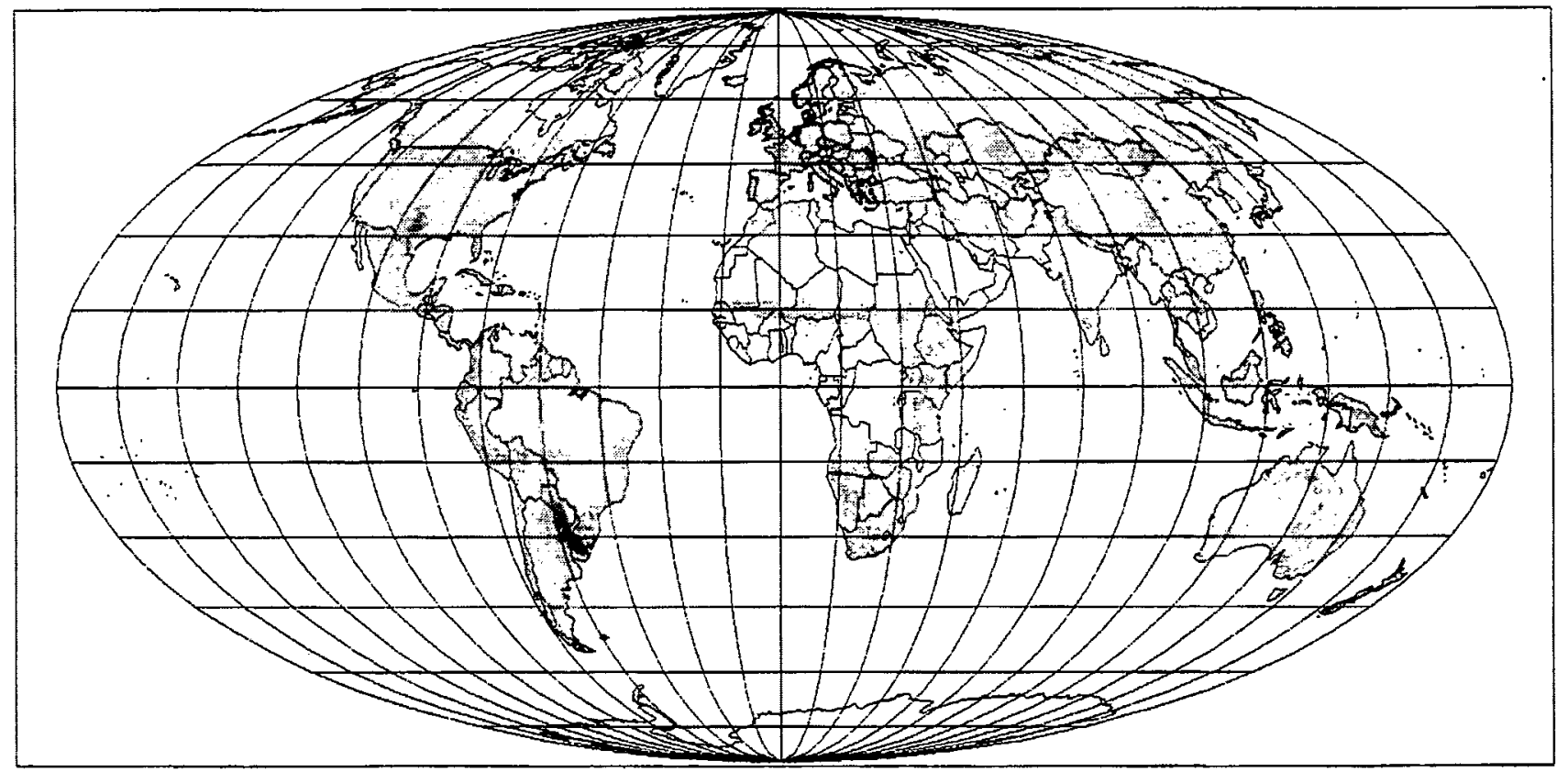

Figure 35. Potential delivery of biofuels to final consumers in 2050 scenario, from centralised production, i.e. special energy crops grown on part of rangeland and minor parts of cropland, expressed by annual energy content (scale given in Figure 4e). 


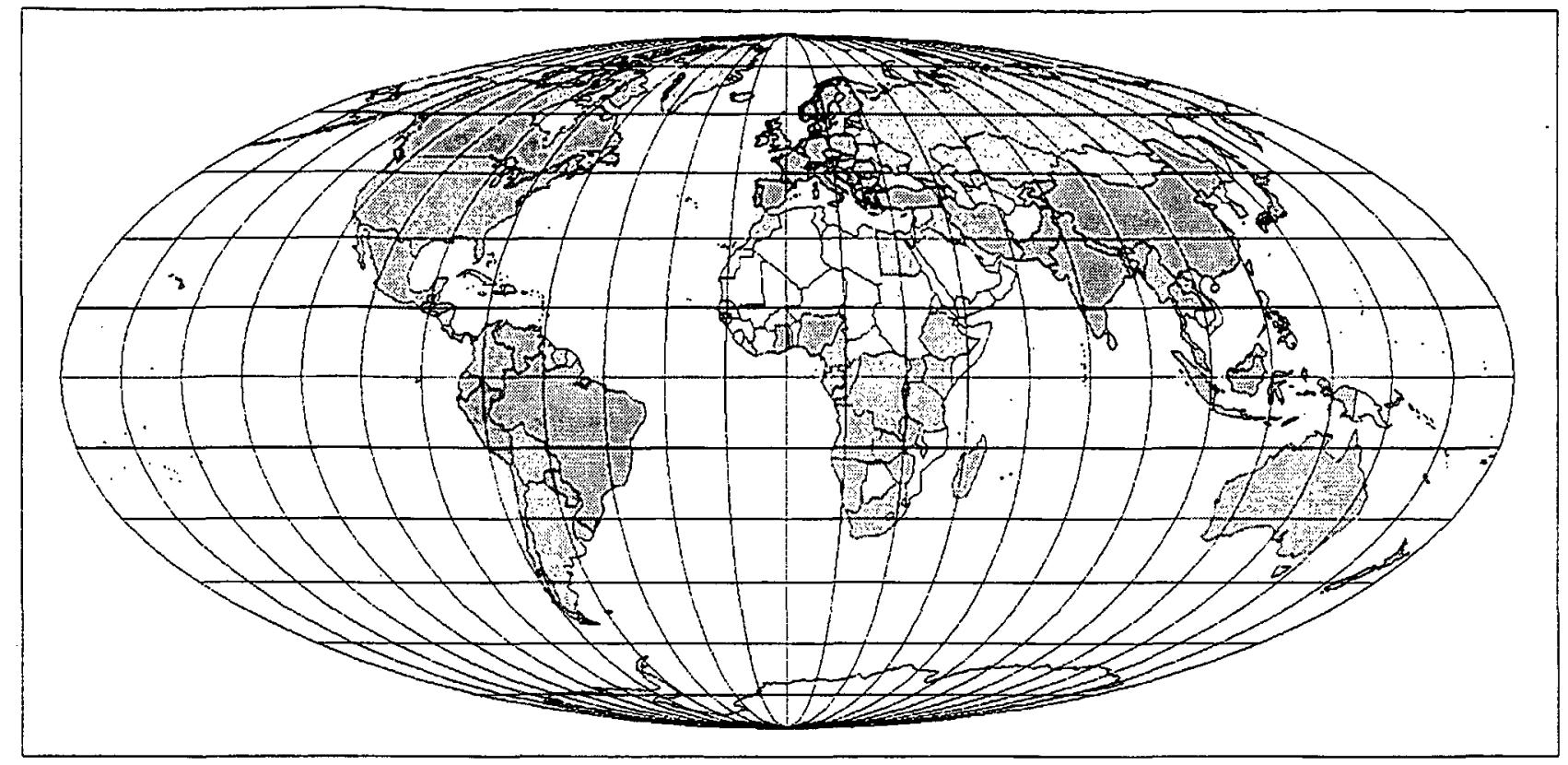

Figure 36. Potential delivery of hydropower to final consumers in 2050 scenario (scale given in Figure $4 \mathrm{e})$.

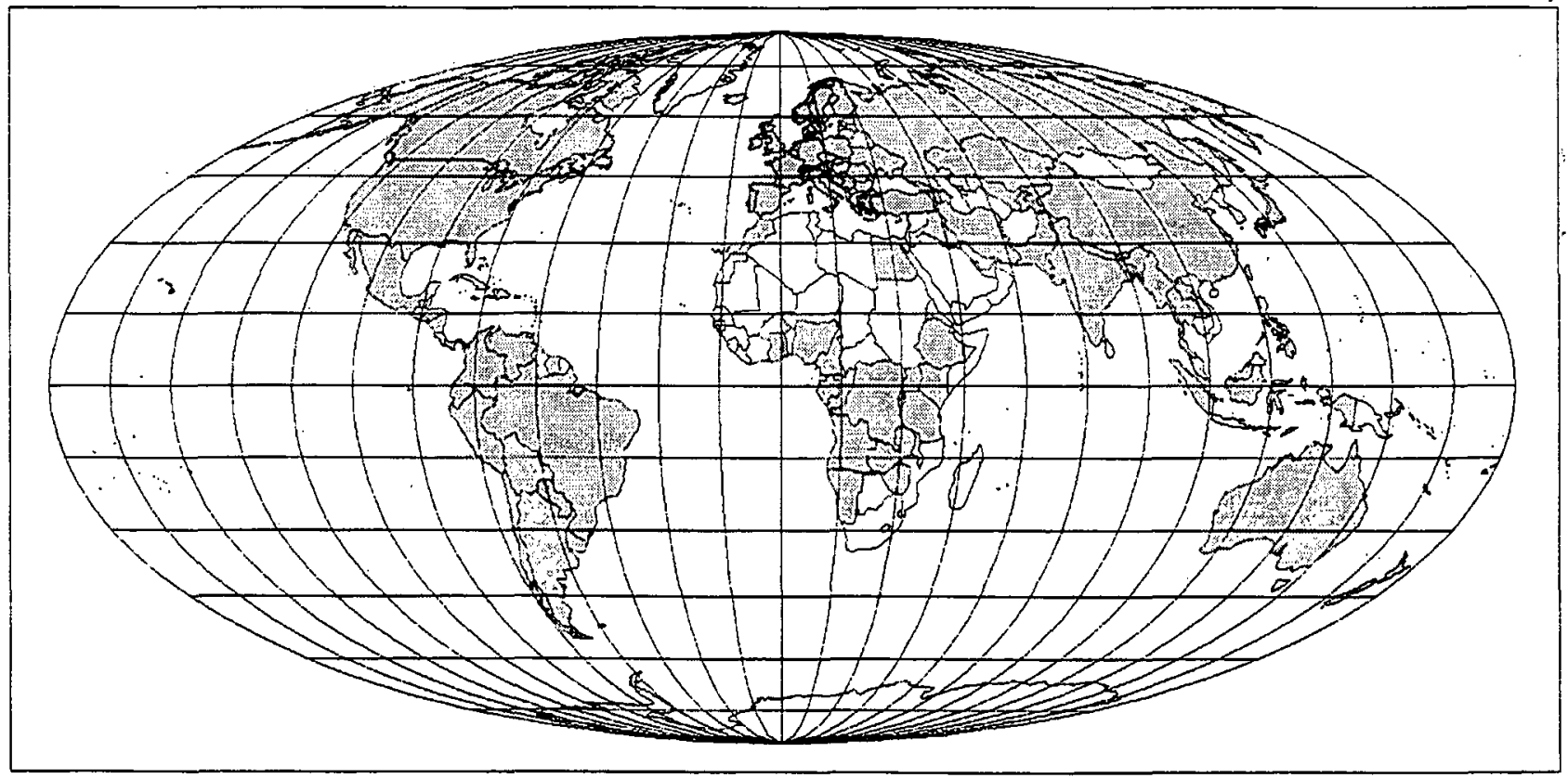

Figure 37. Annual average production of hydropower at existing hydropower plants plus estimated production from plants under construction (scale given in Figure 4e). 


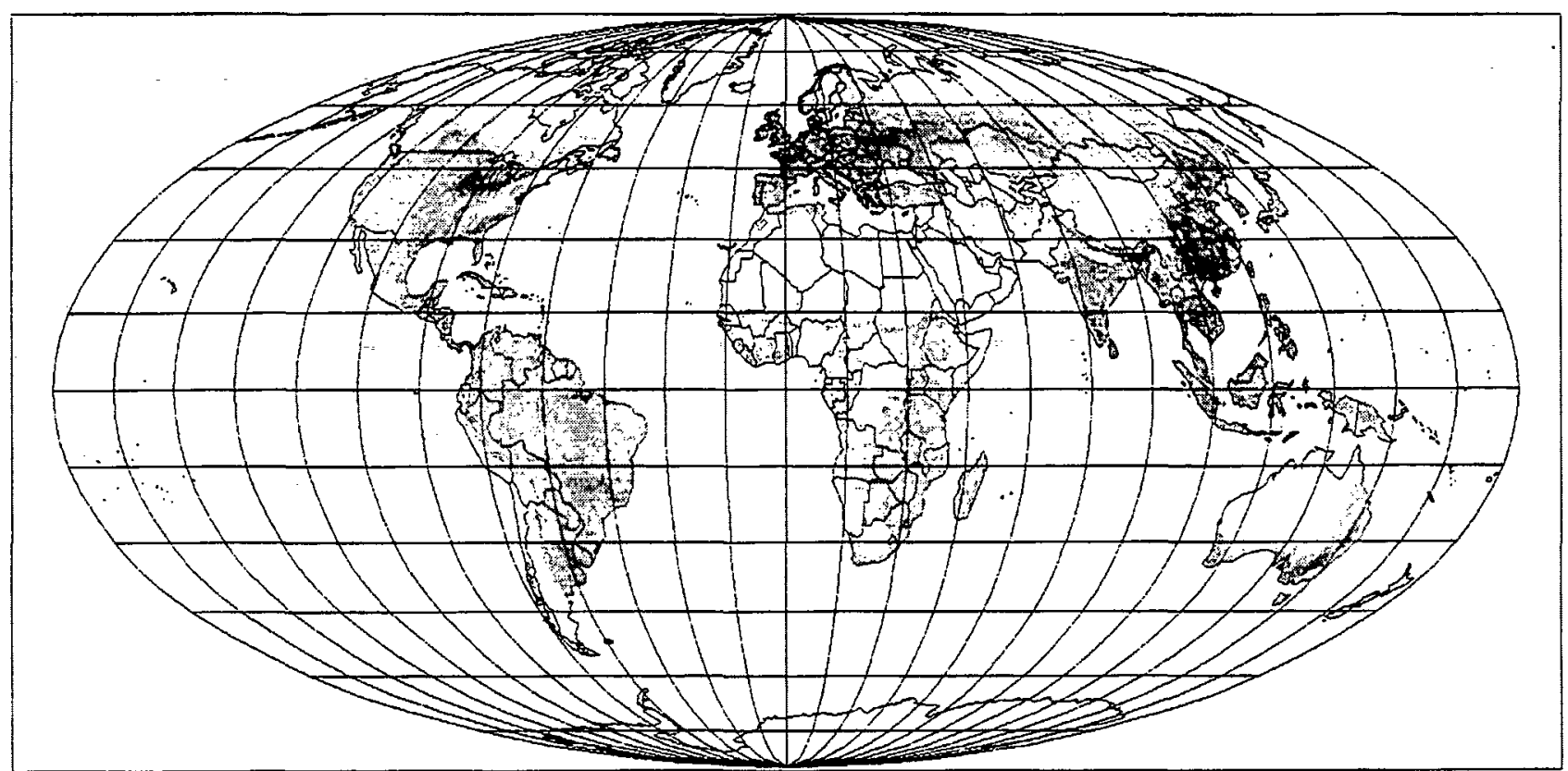

Figure 38. Local surplus of vegetable food supply over demand on an area basis, valid for both decentralised and centralised 2050 scenario. (annual average supply minus demand in $\mathrm{W} / \mathrm{m}^{2}$ is shown if positive; scale given in Figure 4e).

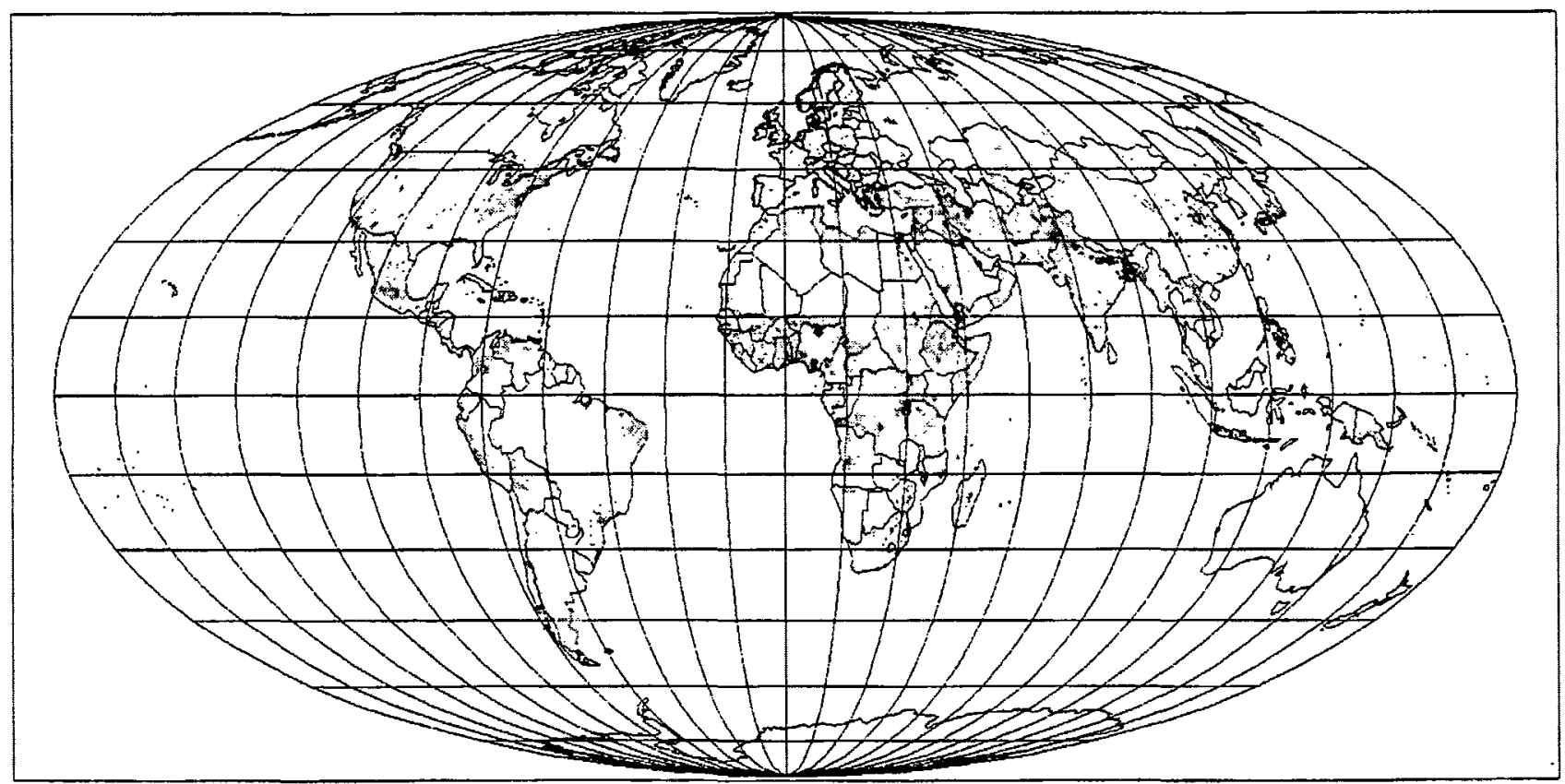

Figure 39a. Local deficit of vegetable food supply relative to demand on an area basis, valid for both decentralised and centralised 2050 scenario. (annual average demand minus supply in $\mathrm{W} / \mathrm{m}^{2}$ is shown if positive; scale given in Figure $39 \mathrm{~b}$ ). 


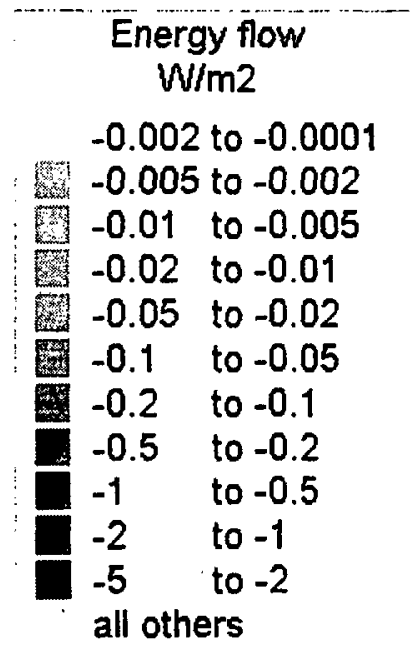

Figure 39b. Scale of negative energy flows (such as deficit in rate of supply relative to demand; note that scale is logarithmic and similar to scale of positive energy flows shown in Figure 4e; unit: $W / \mathrm{m}^{2}$ ).

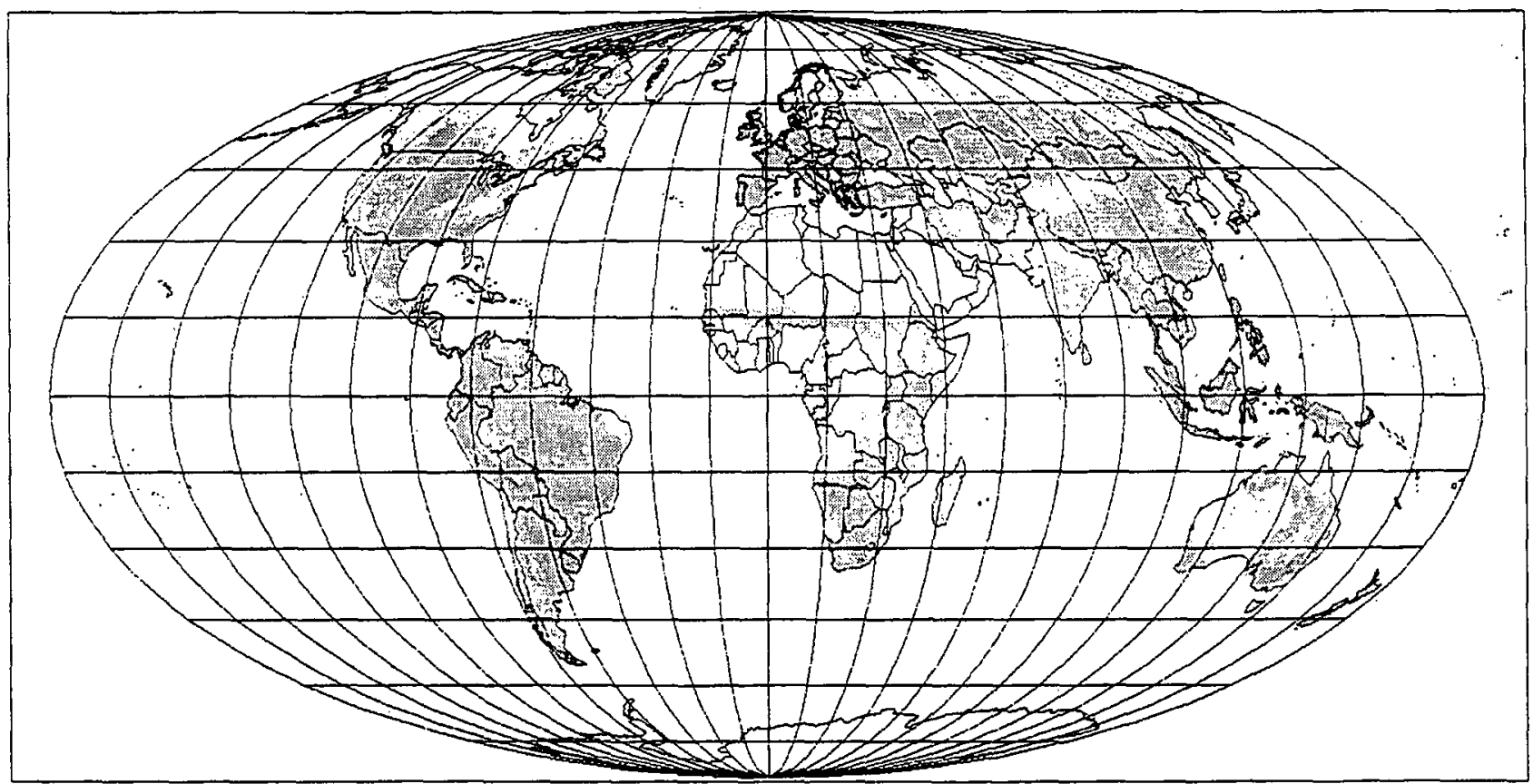

Figure 40. Local surplus of animal-based food supply over demand on an area basis, valid for both decentralised and centralised 2050 scenario. (annual average supply minus demand in $\mathrm{W} / \mathrm{m}^{2}$ is shown if positive; scale given in Figure $4 \mathrm{e}$ ). 


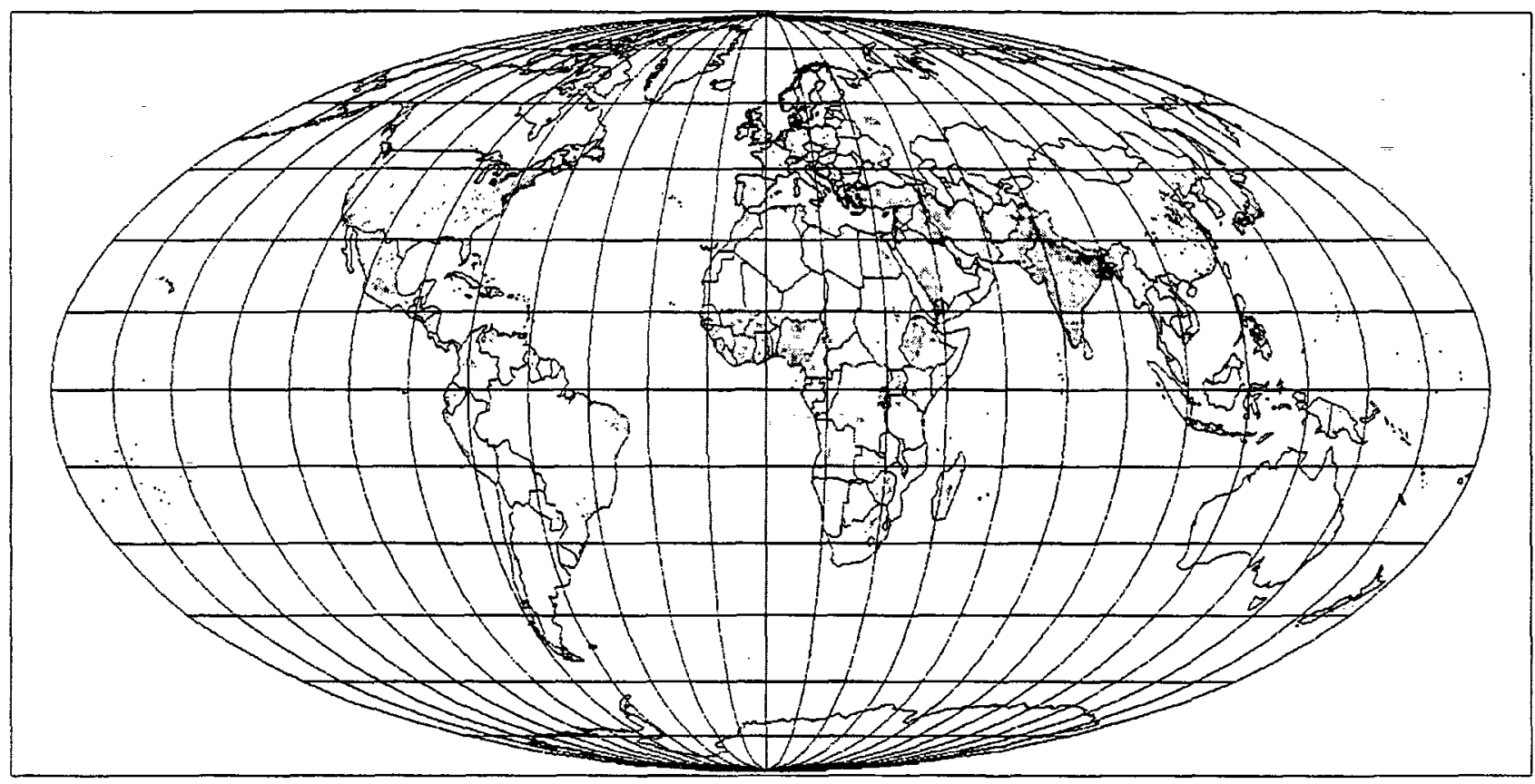

Figure 41. Local deficit of animal-based food supply relative to demand on an area basis, valid for both decentralised and centralised 2050 scenario. (annual average demand minus supply in $\mathrm{W} / \mathrm{m}^{2}$ is shown if positive; scale given in Figure $39 \mathrm{~b}$ ).

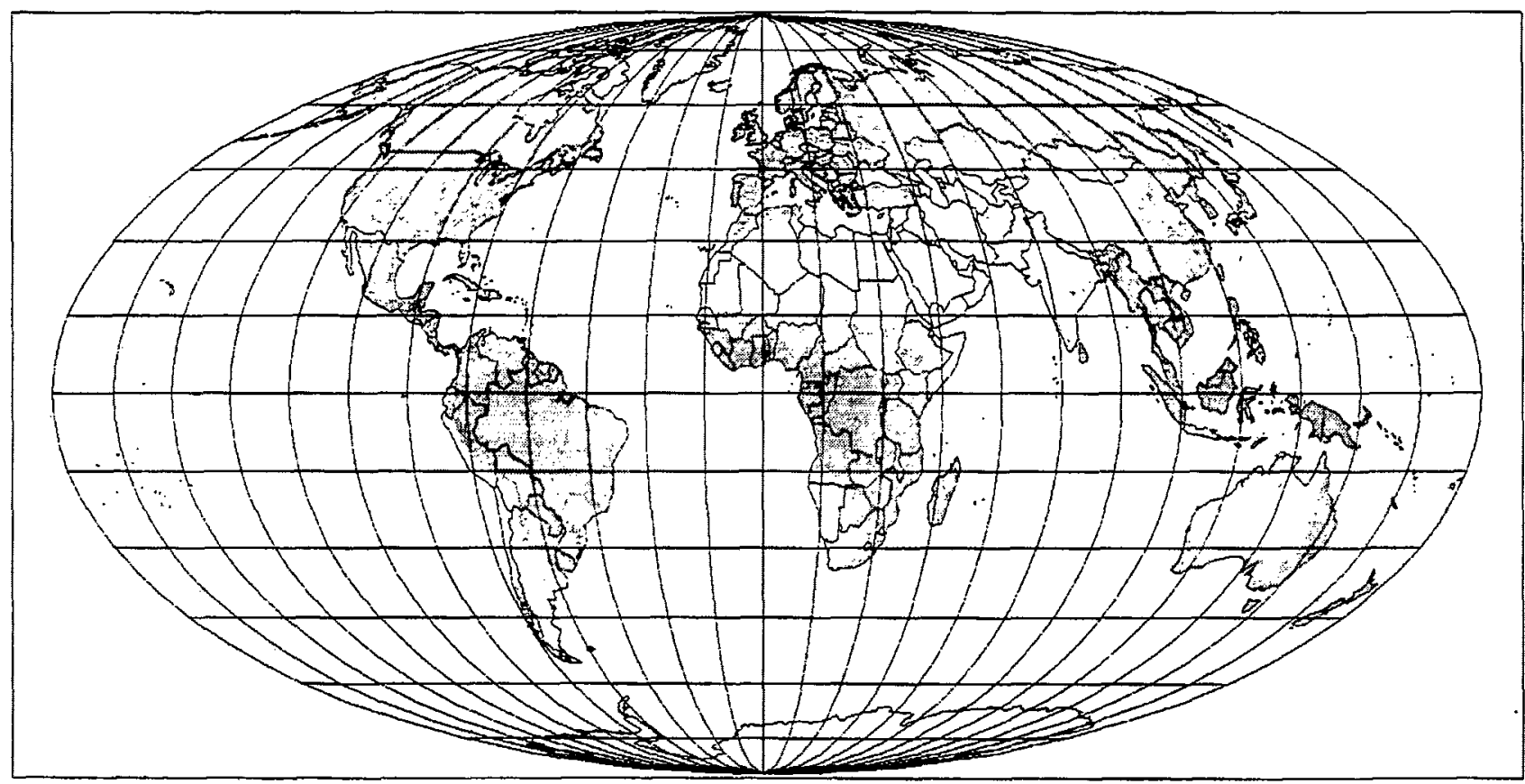

Figure 42. Local surplus of biofuel supplies (such as methanol) over demand for transportation fuels on an area basis, according to the decentralised 2050 scenario. (annual average supply minus demand in $\mathrm{W} / \mathrm{m}^{2}$ is shown if positive; scale given in Figure $4 \mathrm{e}$ ). 


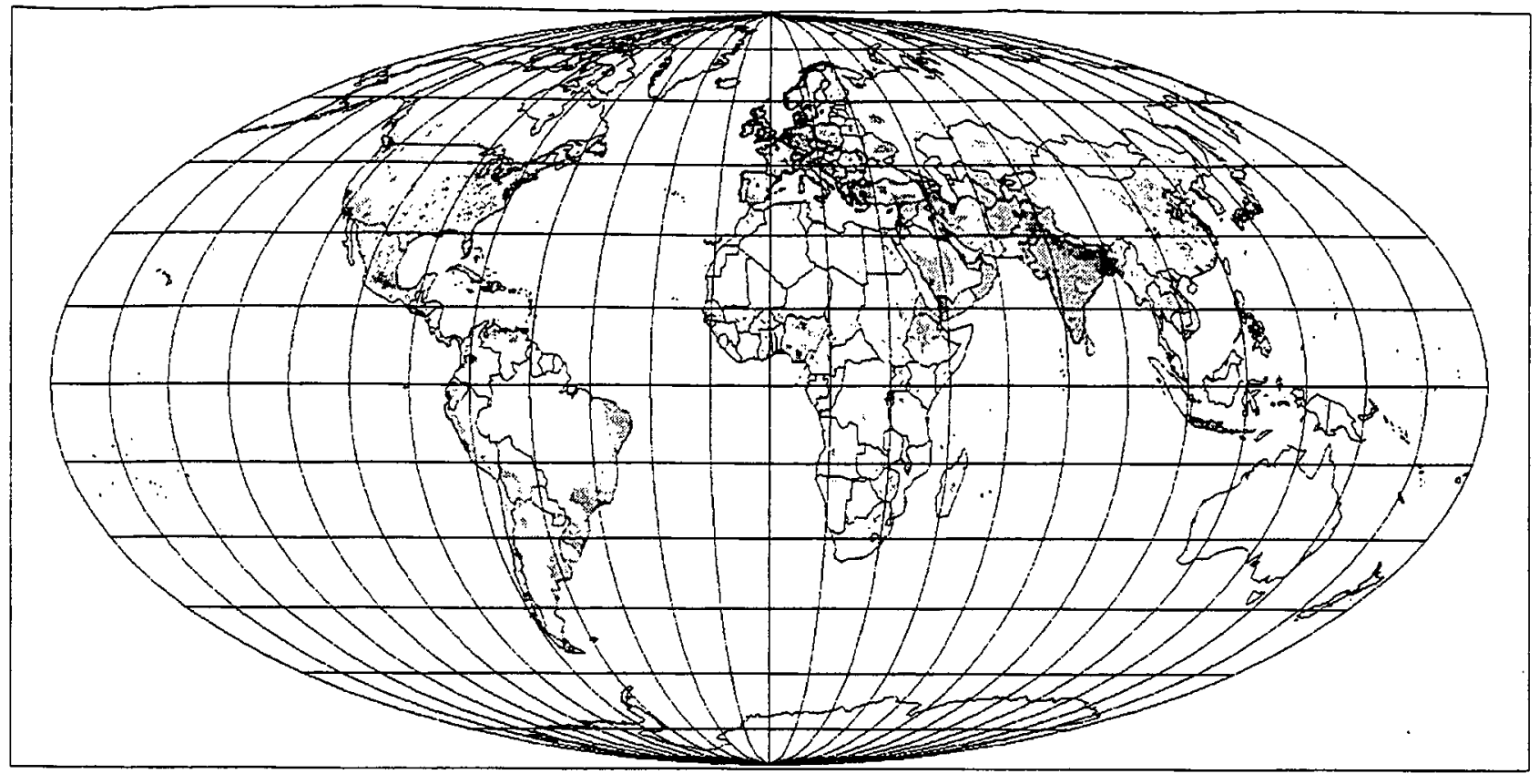

Figure 43. Local deficit of biofuel supplies (such as methanol) relative to demand for transportation fuels on an area basis, according to the decentralised 2050 scenario. (annual average demand minus supply in $\mathrm{W} / \mathrm{m}^{2}$ is shown if positive; scale given in Figure $39 \mathrm{~b}$ ).

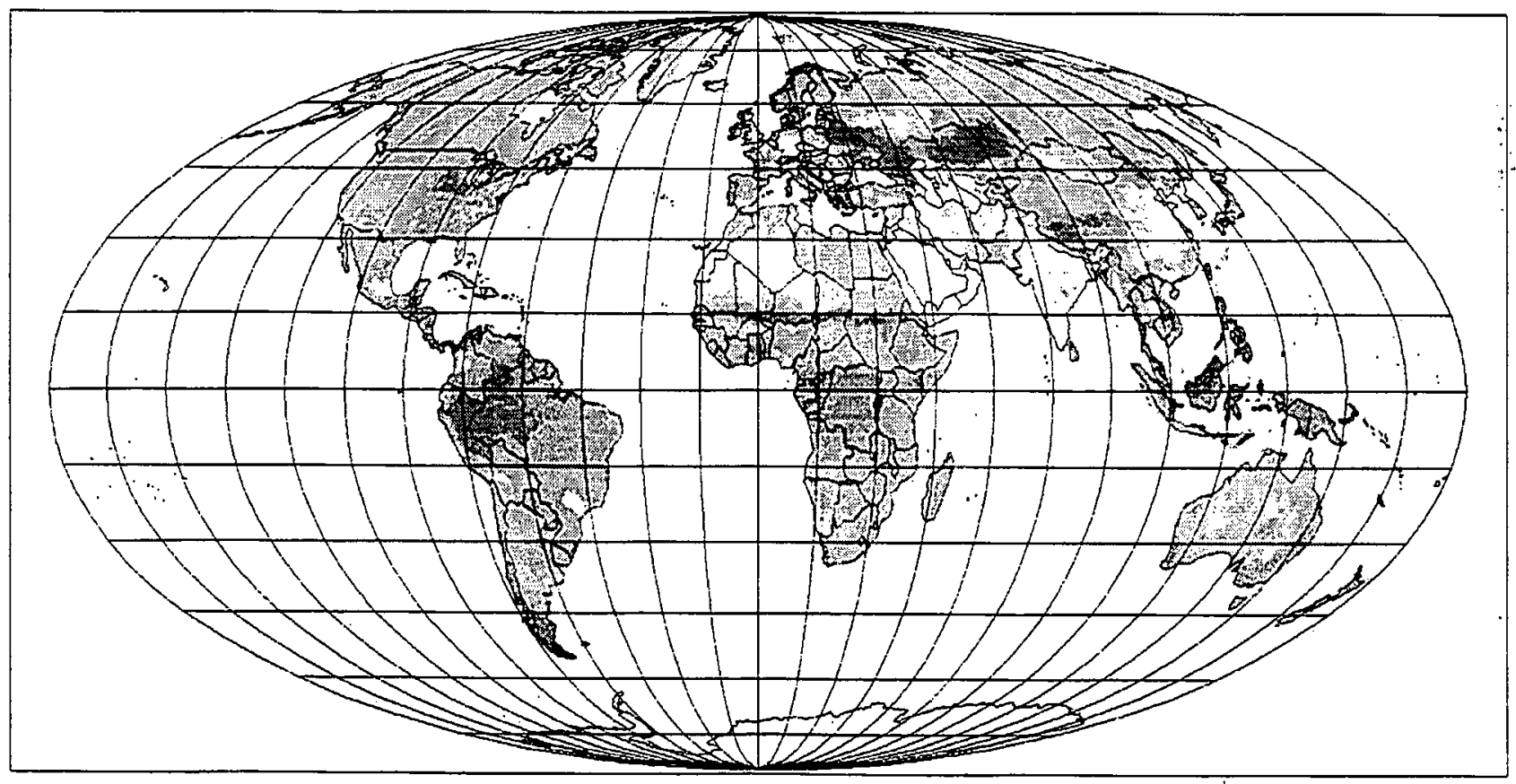

Figure 44. January local surplus of supplies of electricity and biofuels (such as biogas or hydrogen) over demand (all demand except food and transportation) on an area'basis, according to the decentralised 2050 scenario. (average supply minus demand in $\mathrm{W} / \mathrm{m}^{2}$ is shown if positive; scale given in Figure 4e). 


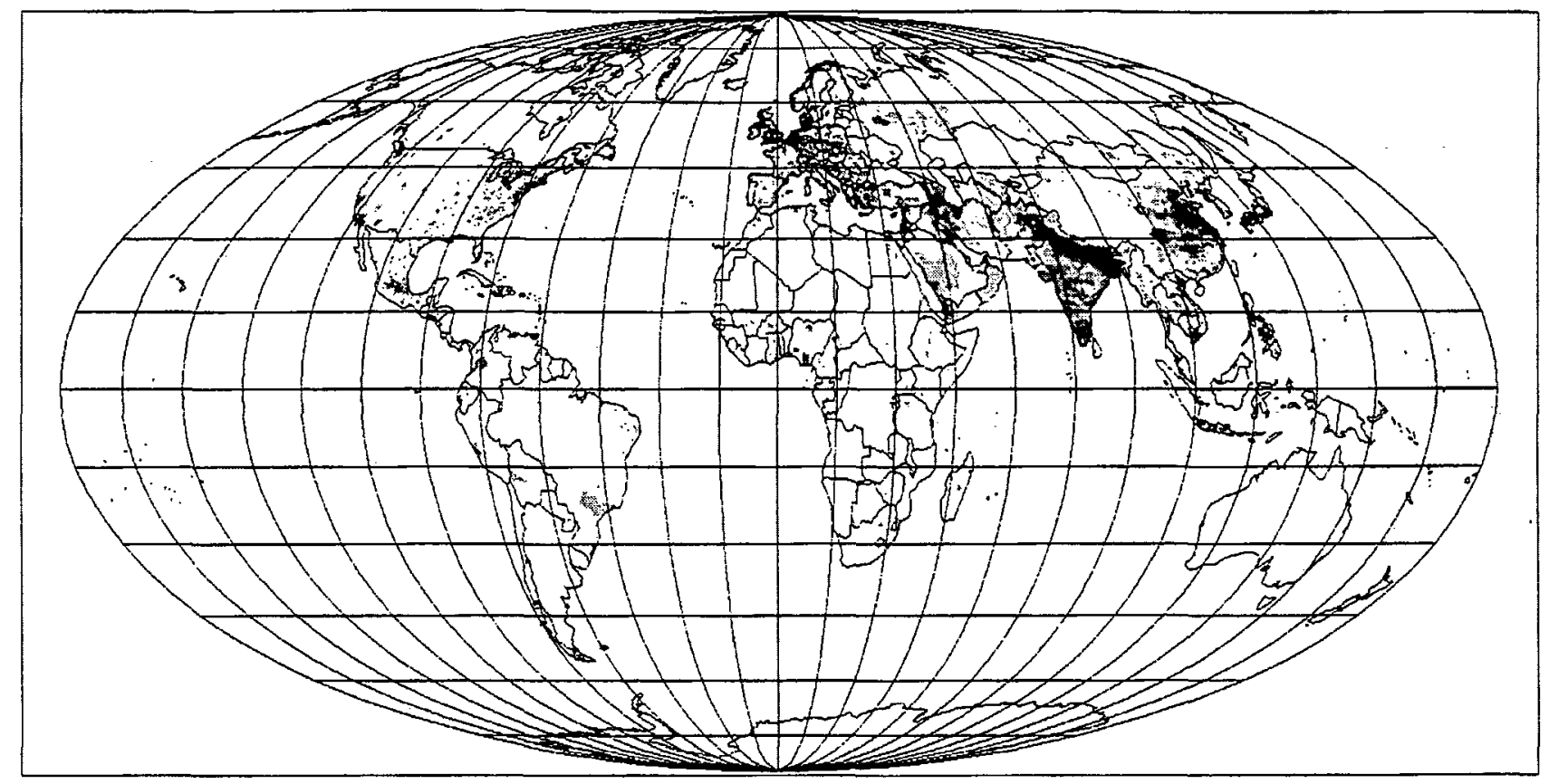

Figure 45. January local deficit of the supplies of electricity and biofuels (such as biogas or hydrogen) relative to demand (all demand except food and transportation) on an area basis, according to the decentralised 2050 scenario. (average demand minus supply in $\mathrm{W} / \mathrm{m}^{2}$ is shown if positive; scale given in Figure $39 \mathrm{~b}$ ).

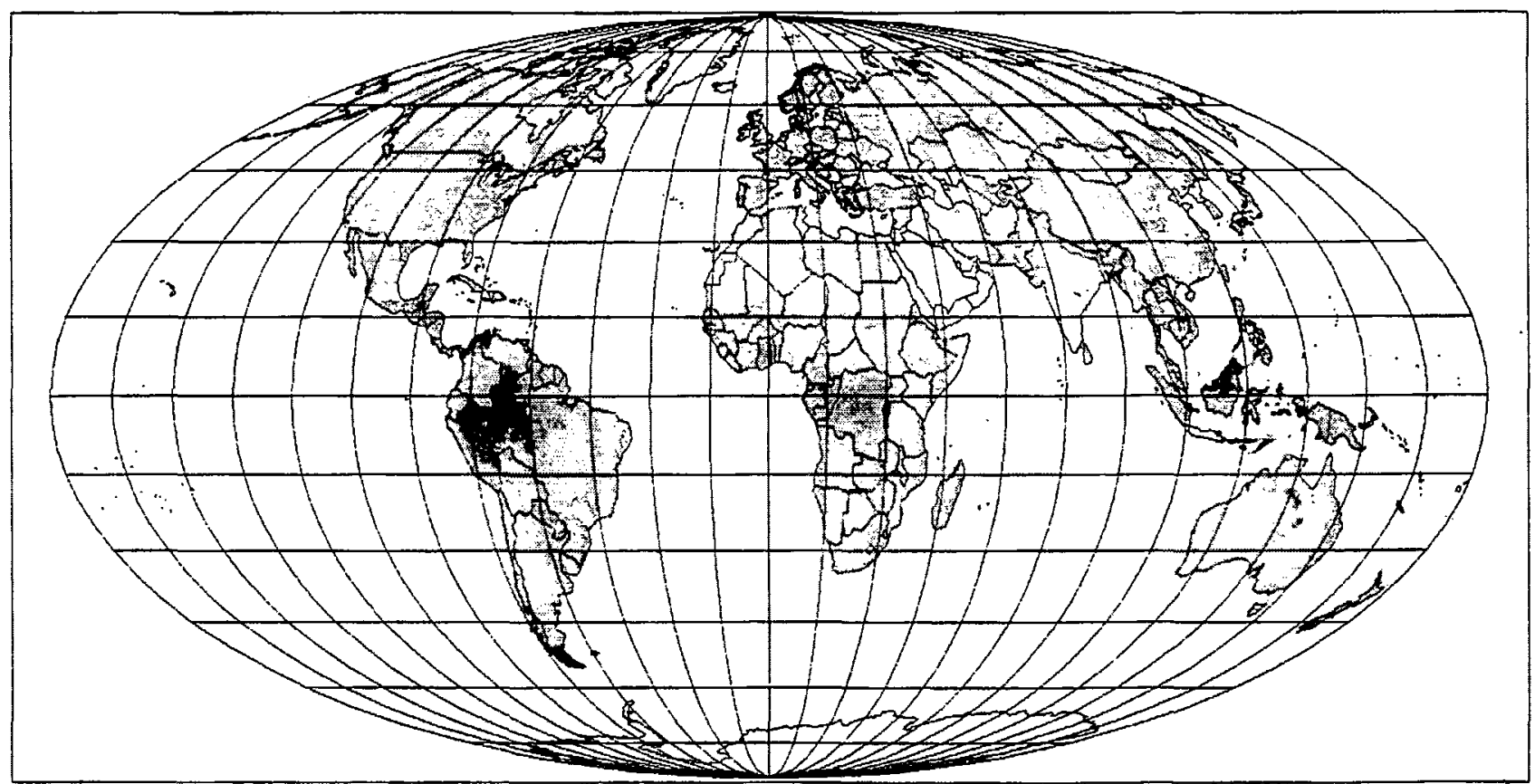

Figure 46. April local surplus of supplies of electricity and biofuels (such as biogas or hydrogen) over demand (all demand except food and transportation) on an area basis, according to the decentralised 2050 scenario. (average supply minus demand in $\mathrm{W} / \mathrm{m}^{2}$ is shown if positive; scale given in Figure 4e). 


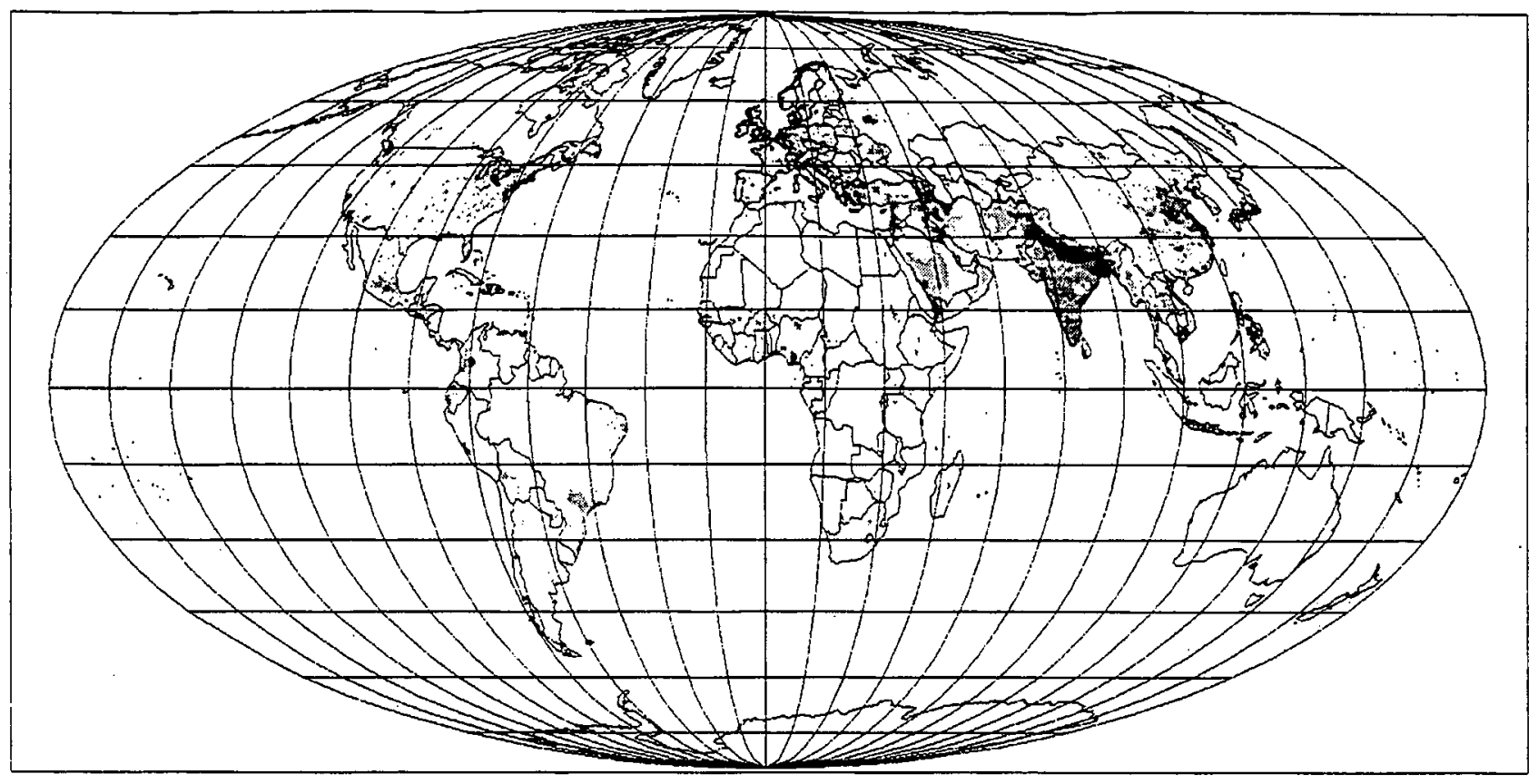

Figure 47. April local deficit of the supplies of electricity and biofuels (such as biogas or hydrogen) relative to demand (all demand except food and transportation) on an area basis, according to the decentralised 2050 scenario. (average demand minus supply in $\mathrm{W} / \mathrm{m}^{2}$ is shown if positive; scale given in Figure 39b).

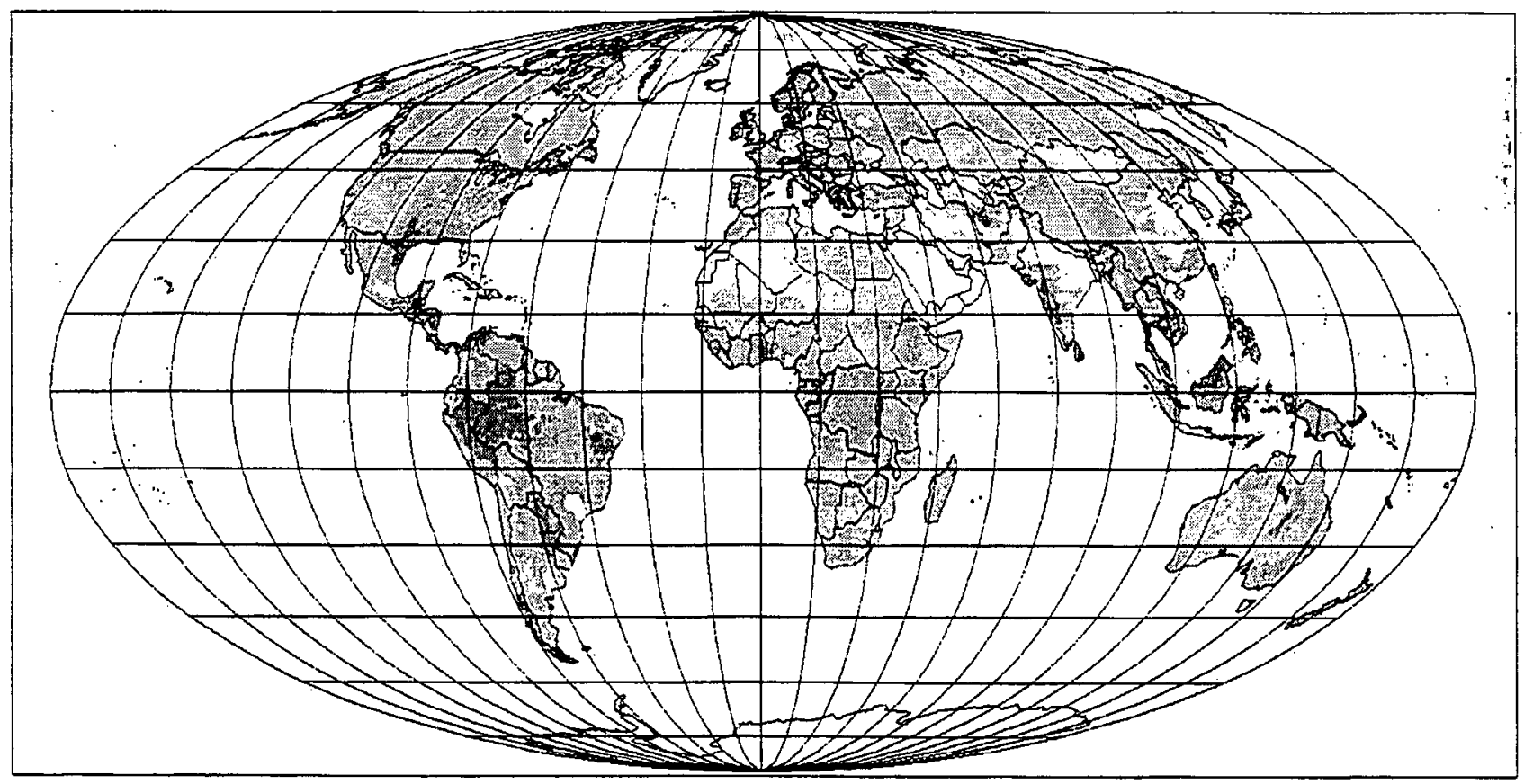

Figure 48. July local surplus of supplies of electricity and biofuels (such as biogas or hydrogen) over demand (all demand except food and transportation) on an area basis, according to the decentralised 2050 scenario. (average supply minus demand in $\mathrm{W} / \mathrm{m}^{2}$ is shown if positive; scale given in Figure 4e). 


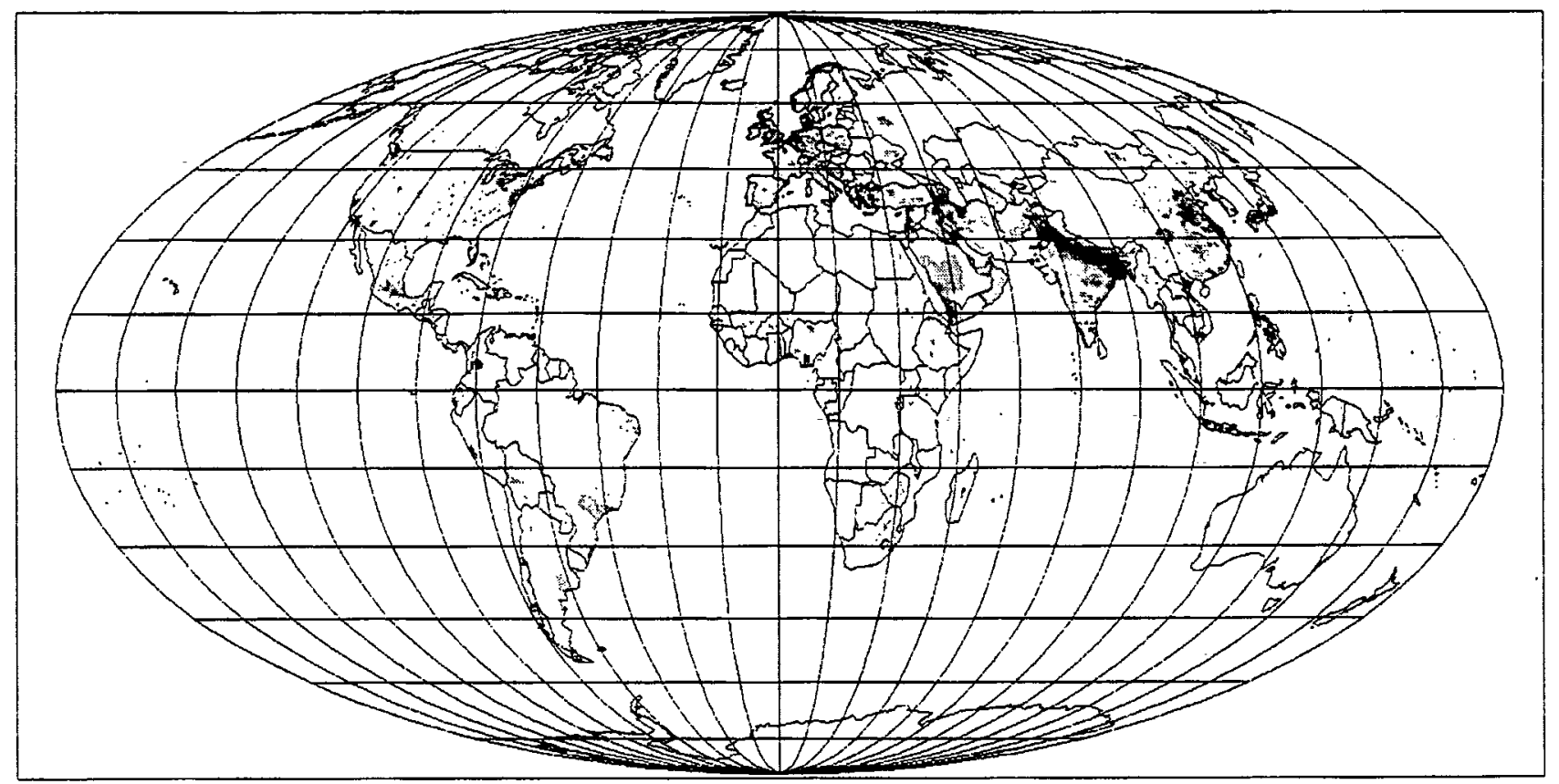

Figure 49. July local deficit of the supplies of electricity and biofuels (such as biogas or hydrogen) relative to demand (all demand except food and transportation) on an area basis, according to the decentralised 2050 scenario. (average demand minus supply in $\mathrm{W} / \mathrm{m}^{2}$ is shown if positive; scale given in Figure 39b).

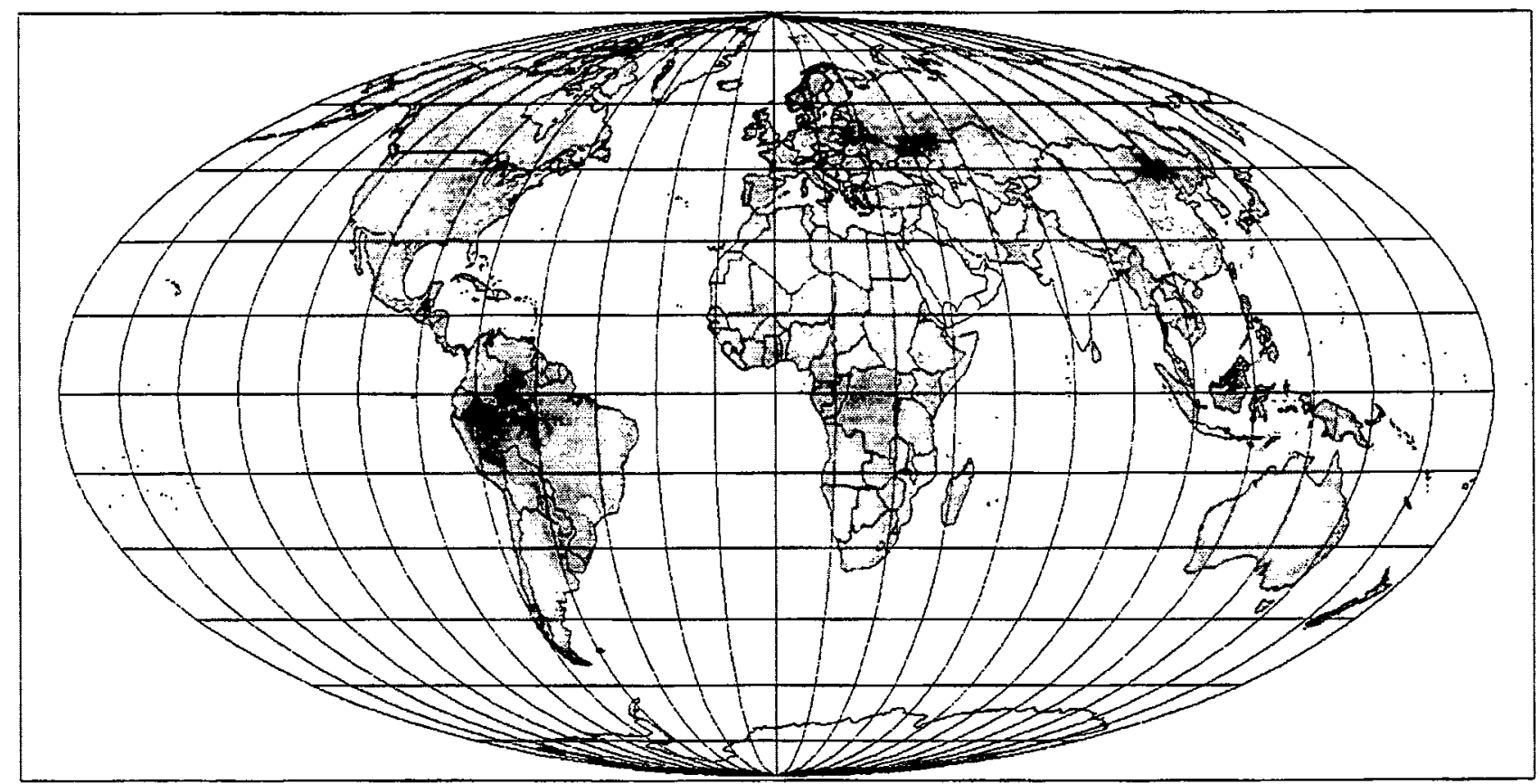

Figure 50. October local surplus of supplies of electricity and biofuels (such as biogas or hydrogen) over demand (all demand except food and transportation) on an area basis, according to the decentralised 2050 scenario. (average supply minus demand in $\mathrm{W} / \mathrm{m}^{2}$ is shown if positive; scale given in Figure 4e). 


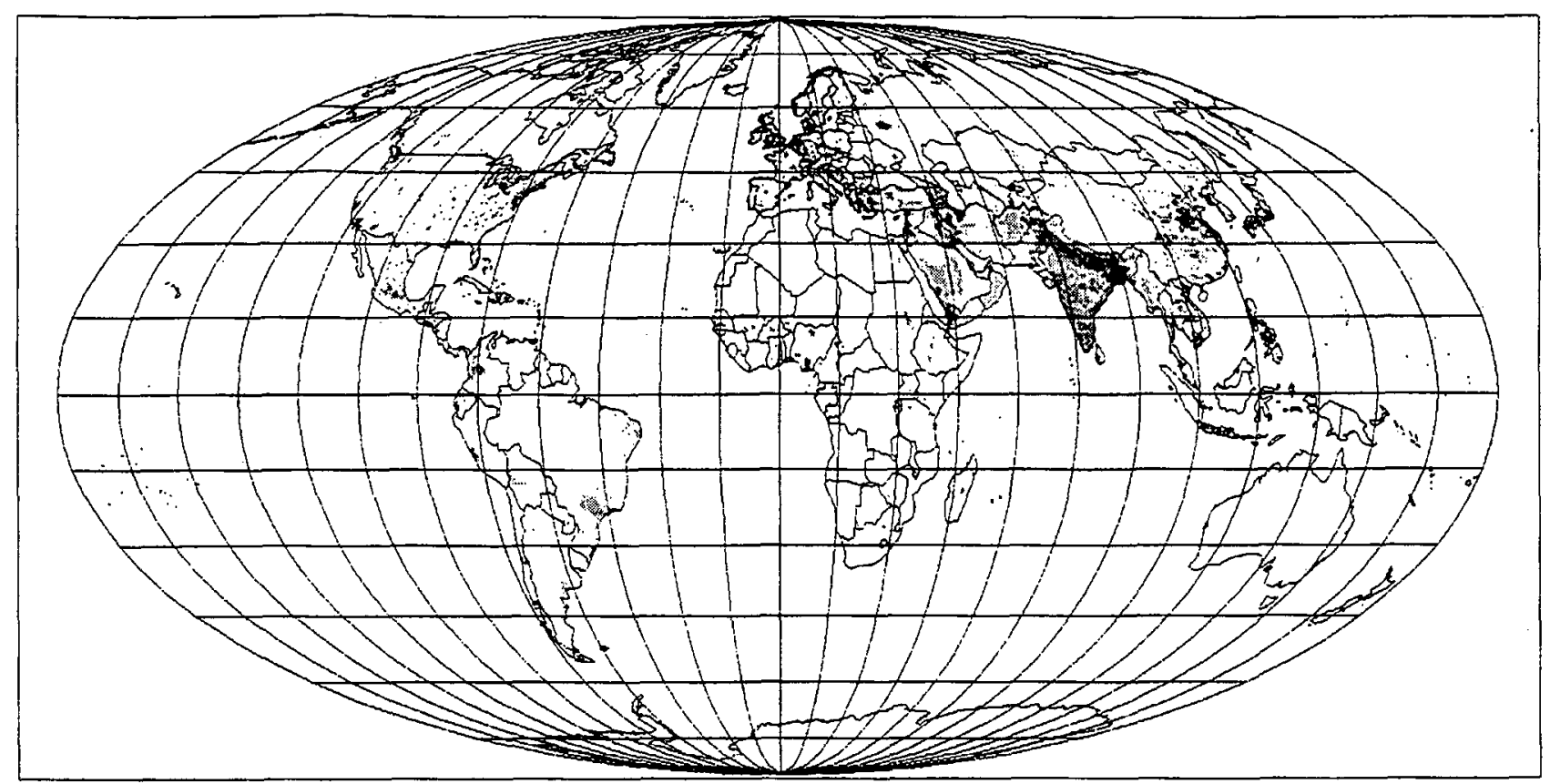

Figure 51. October local deficit of the supplies of electricity and biofuels (such as biogas or hydrogen) relative to demand (all demand except food and transportation) on an area basis, according to the decentralised 2050 scenario. (average demand minus supply in $\mathrm{W} / \mathrm{m}^{2}$ is shown if positive; scale given in Figure $39 b$ ).

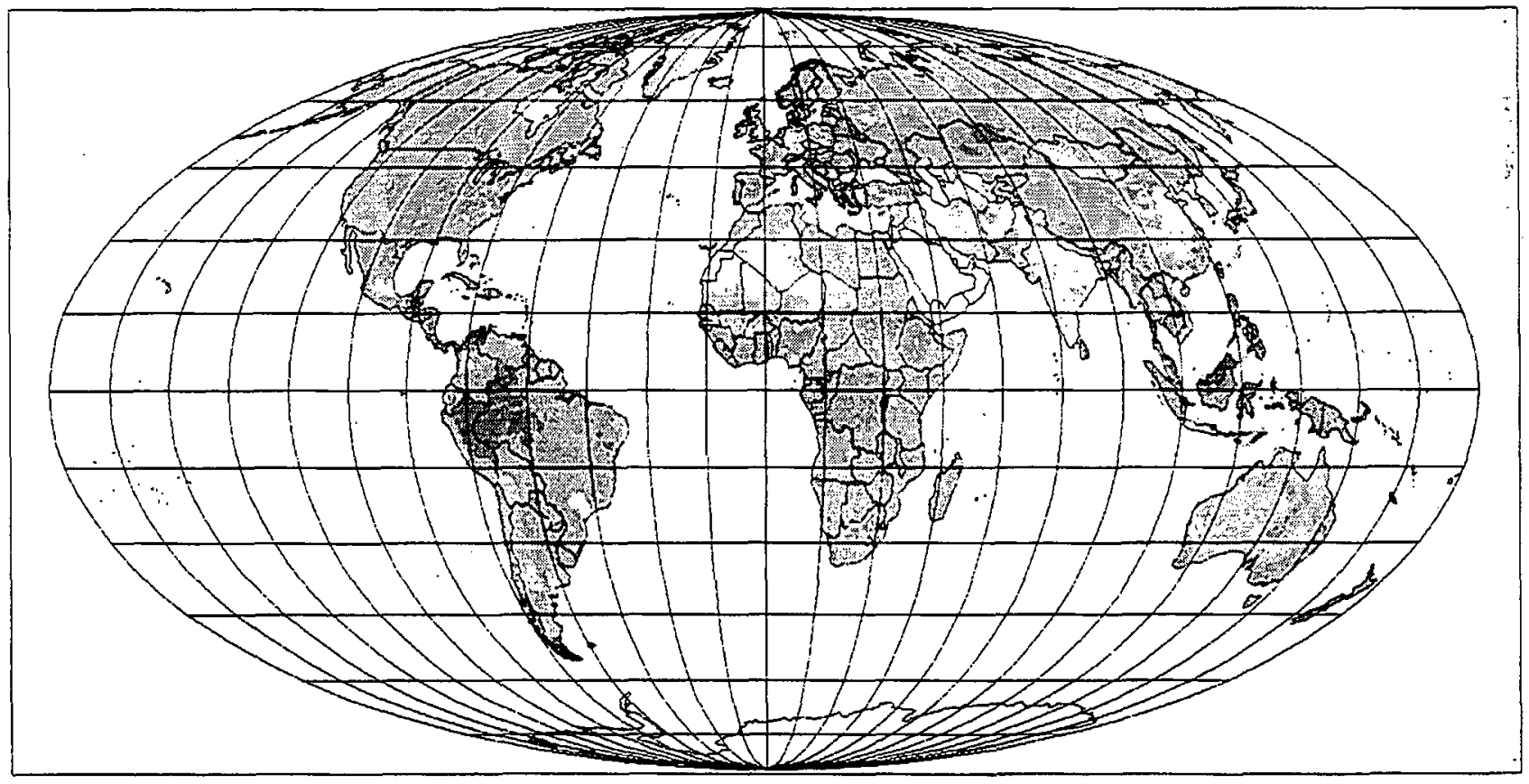

Figure 52. Annual average local surplus of supplies of electricity and biofuels (such as biogas or hydrogen) over demand (all demand except food and transportation) on an area basis, according to the decentralised 2050 scenario. (average supply minus demand in $\mathrm{W} / \mathrm{m}^{2}$ is shown if positive; scale given in Figure 4e). 


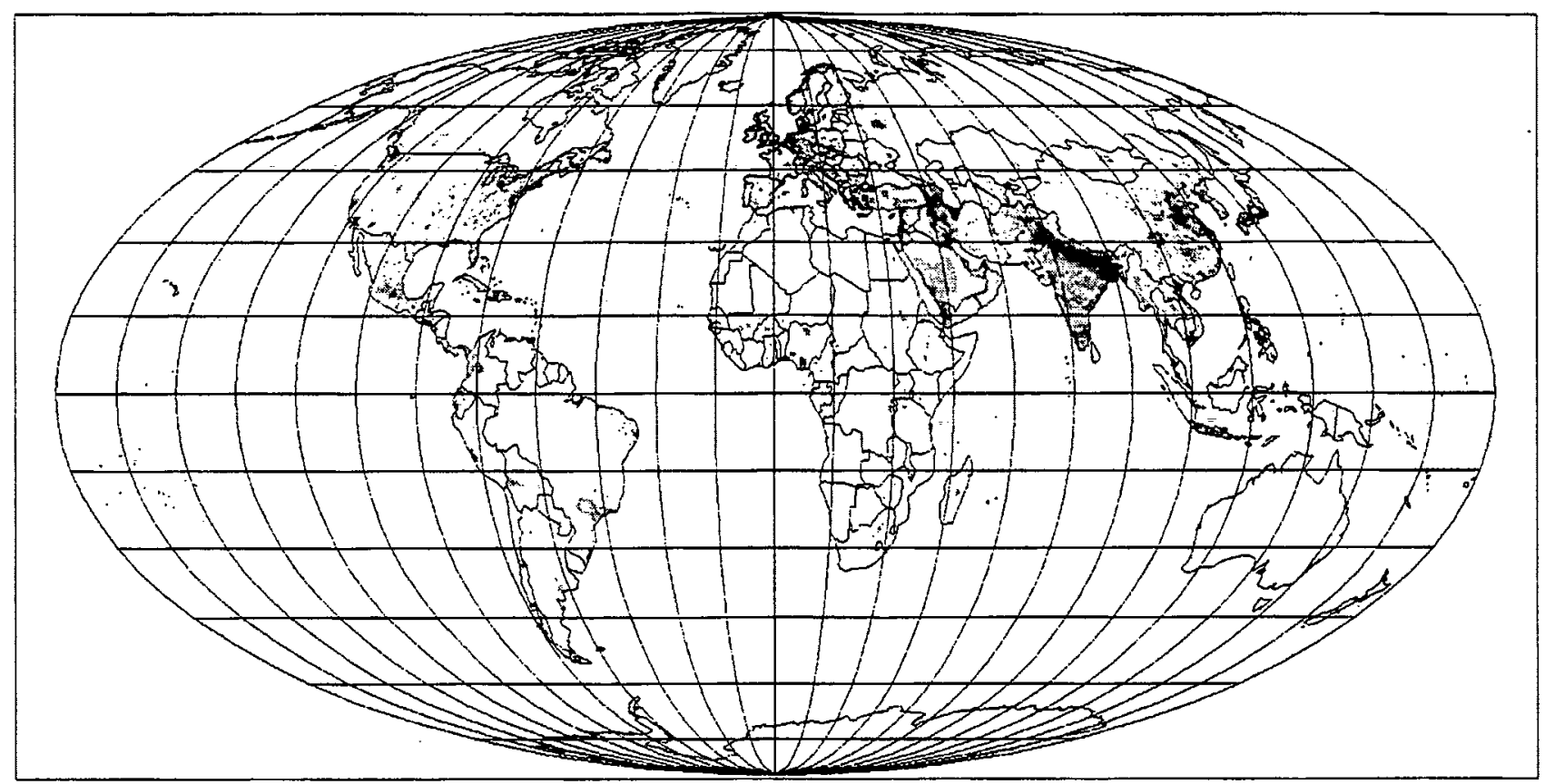

Figure 53. Annual average local deficit of the supplies of electricity and biofuels (such as biogas or hydrogen) relative to demand (all demand except food and transportation) on an area basis, according to the decentralised 2050 scenario. (average demand minus supply in W/m $\mathrm{m}^{2}$ is shown if positive; scale given in Figure 39b). 

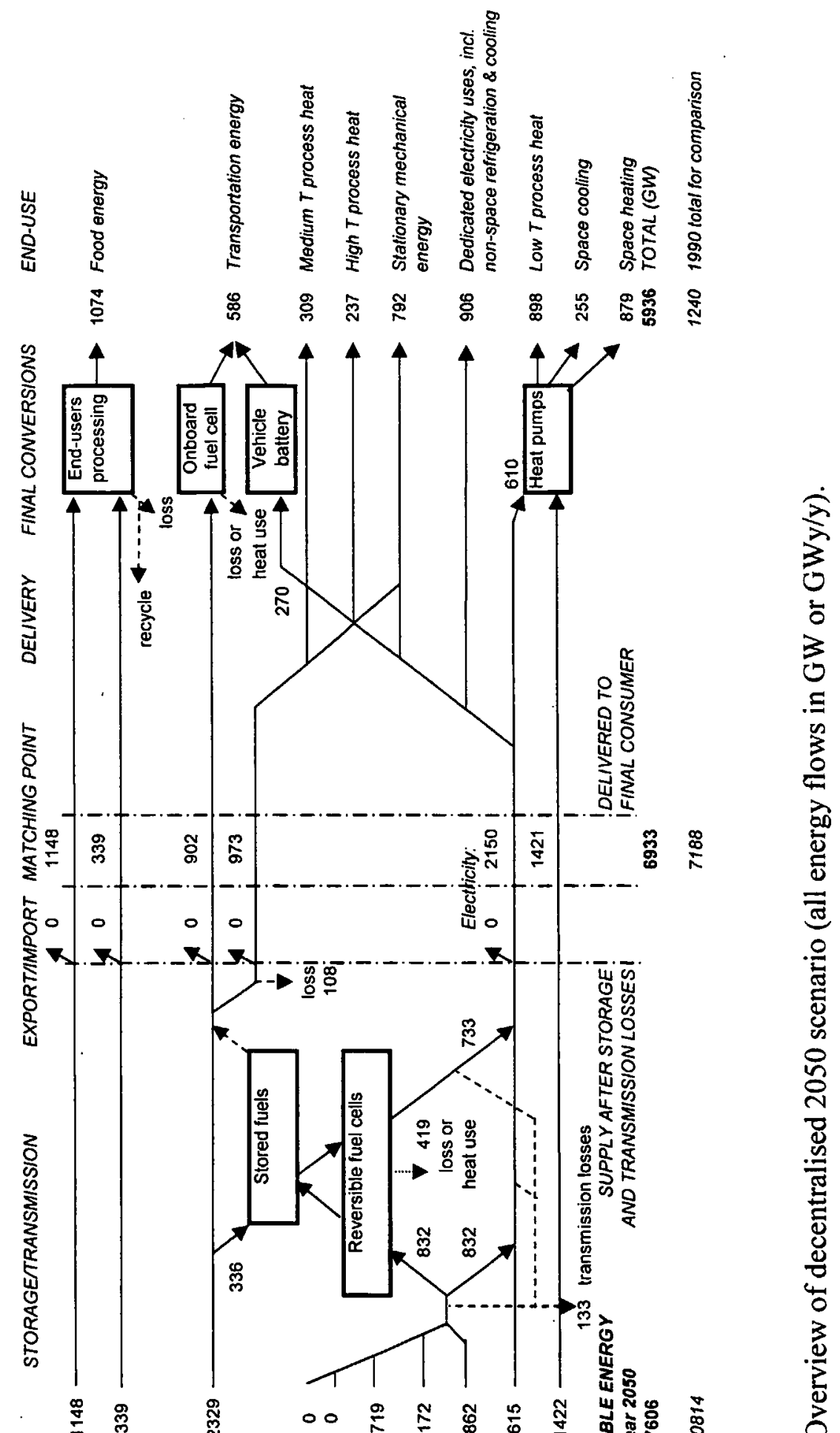

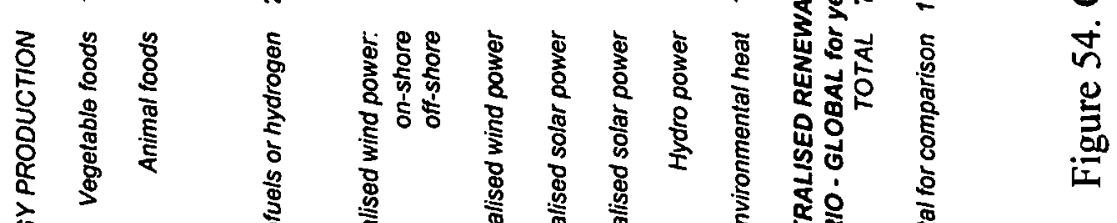




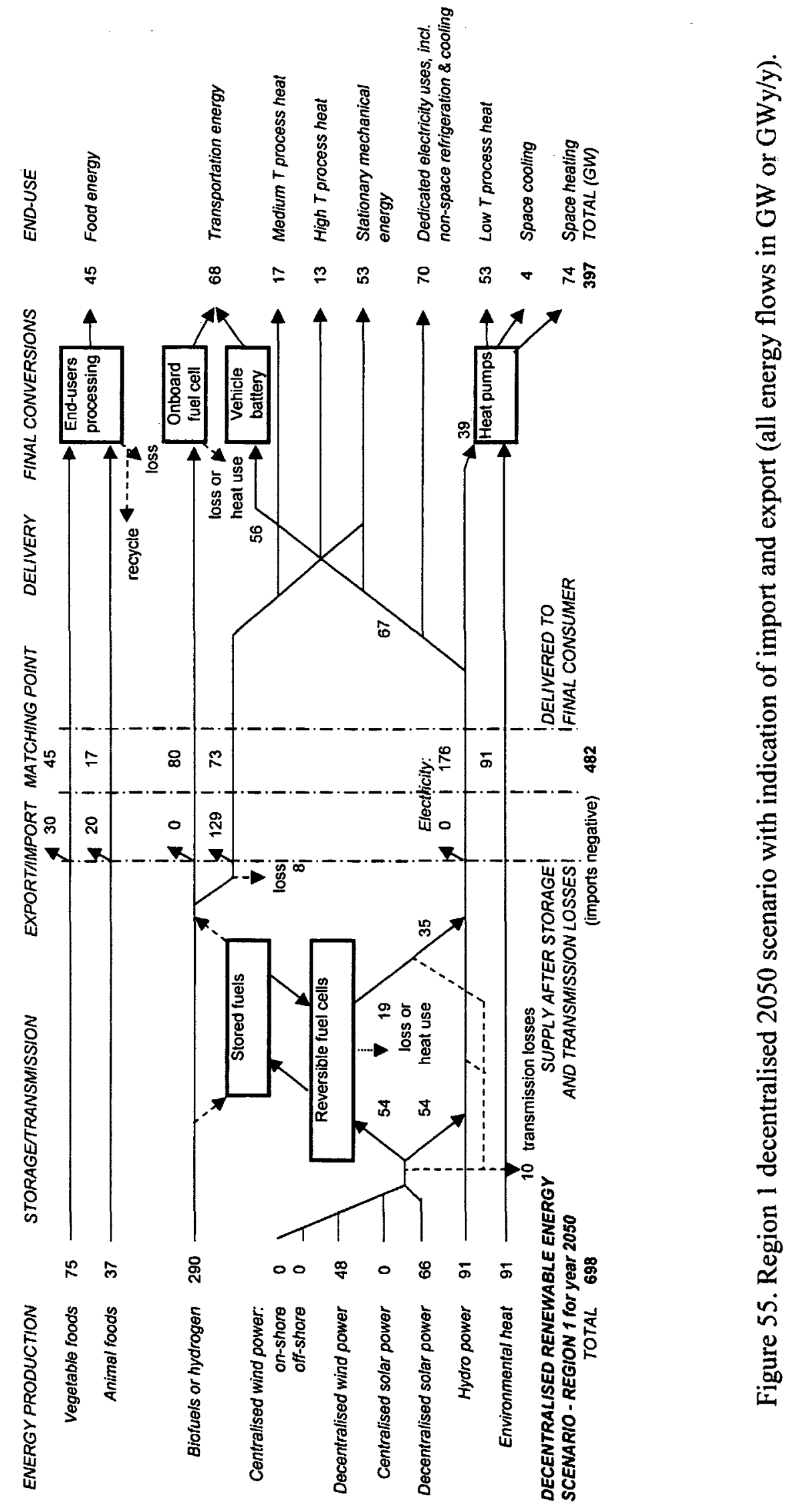




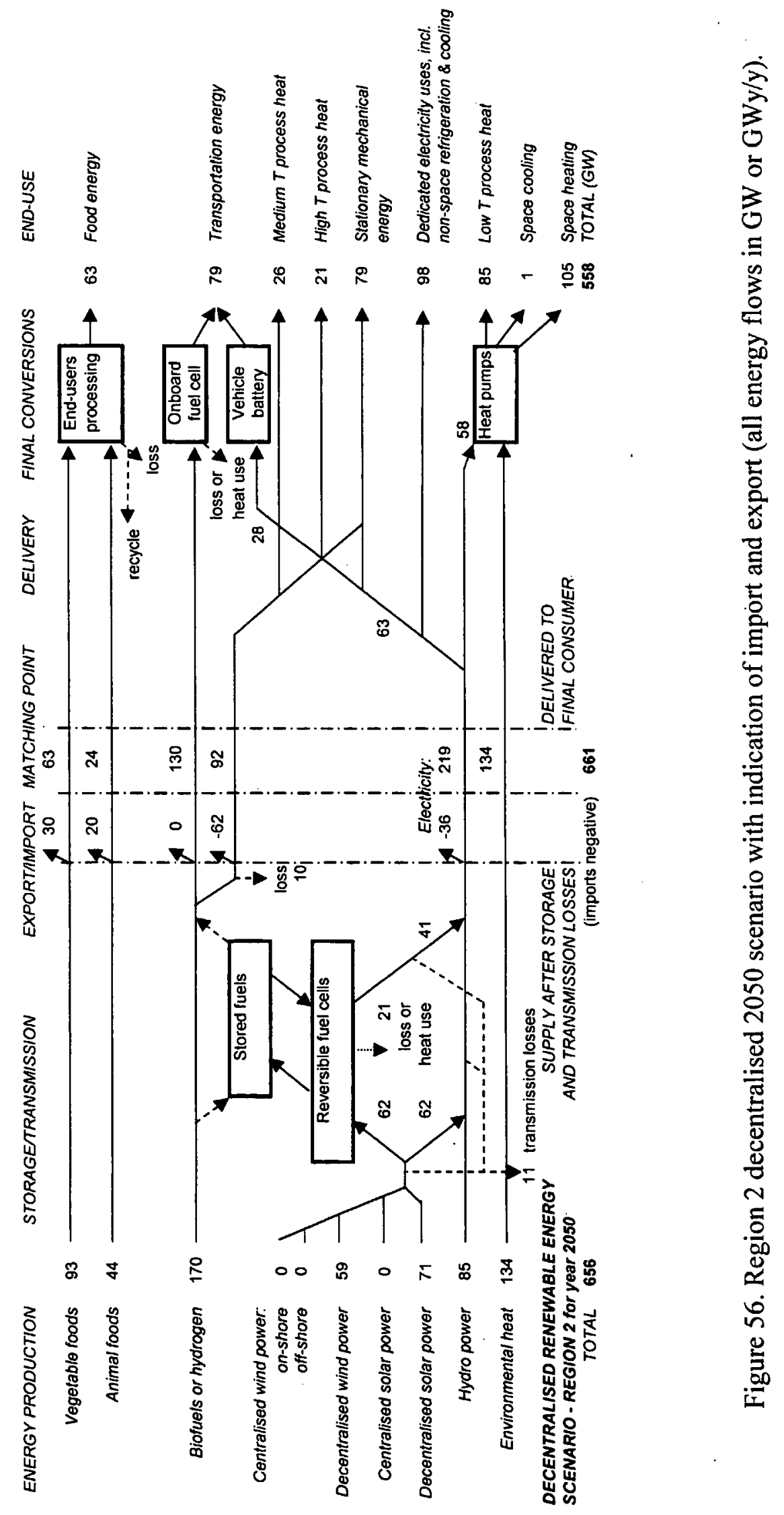




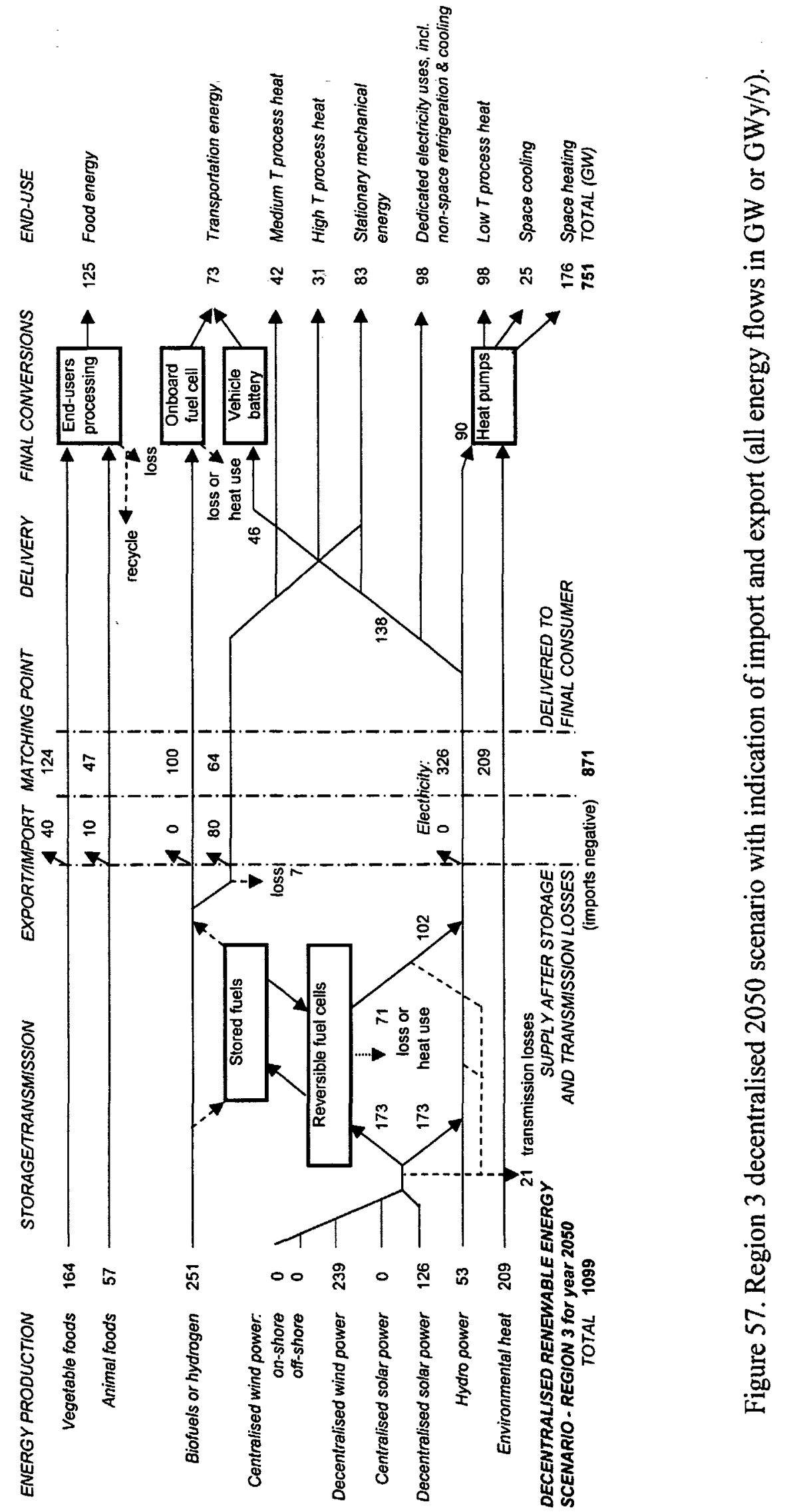




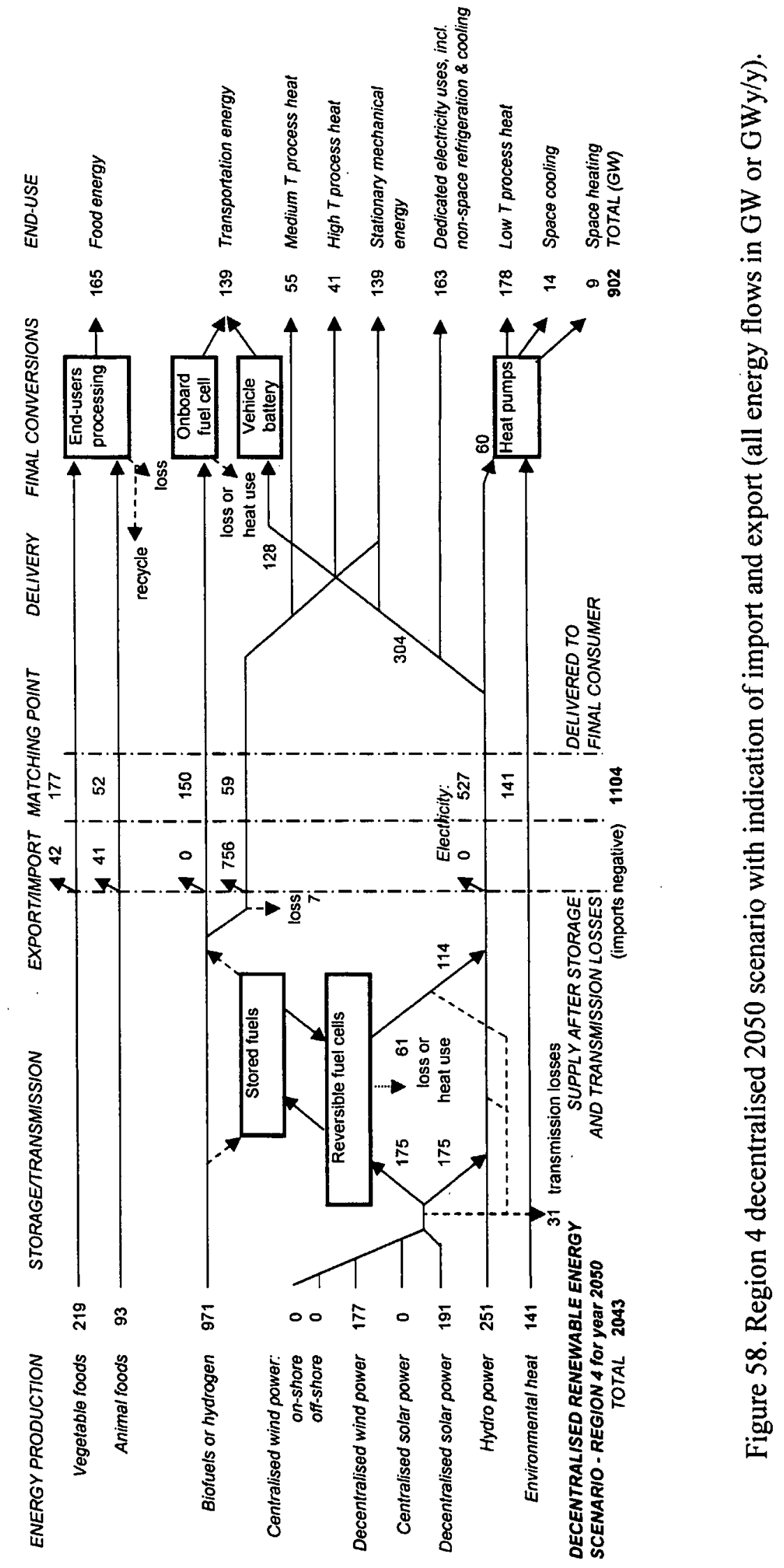




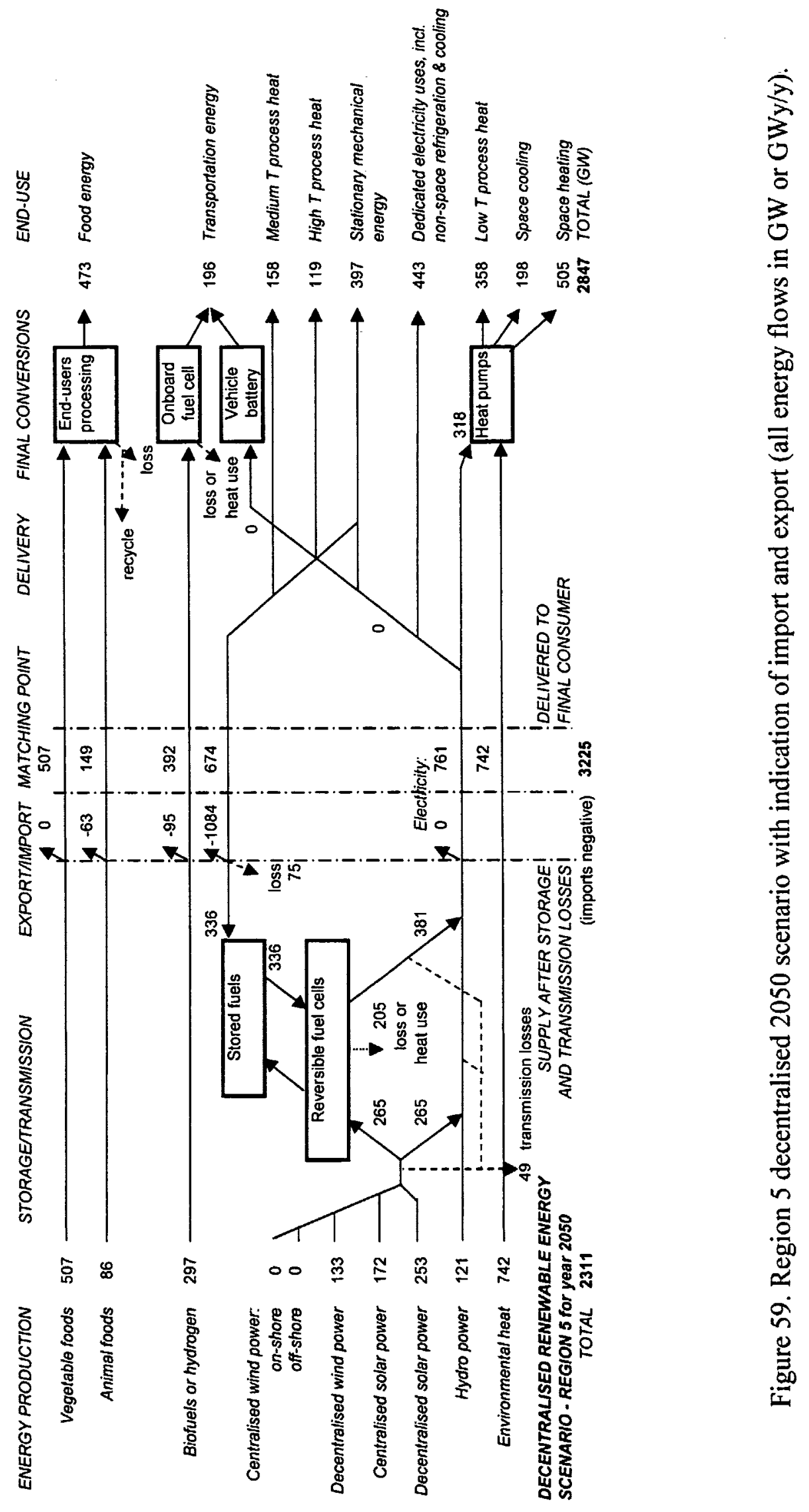




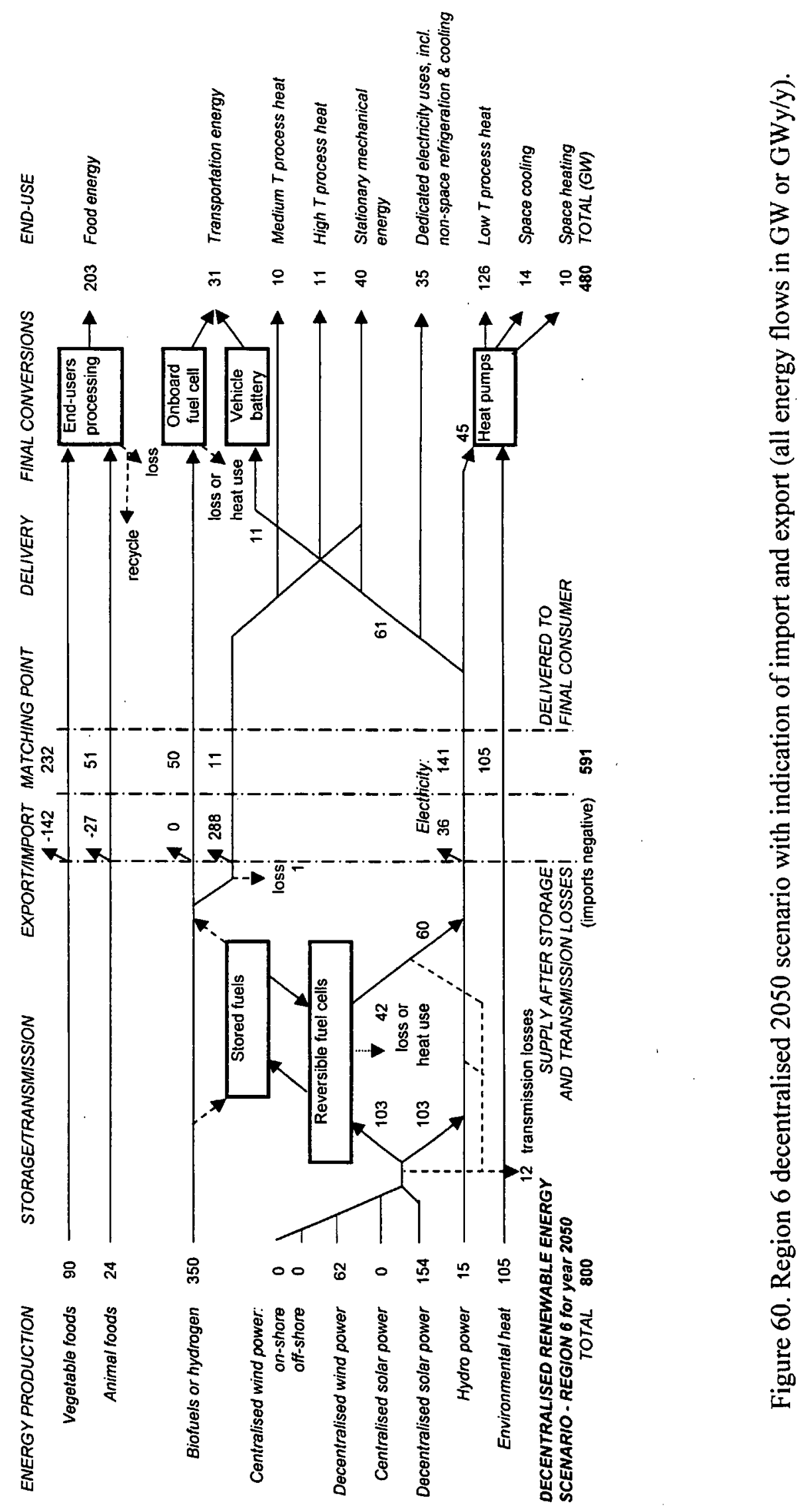




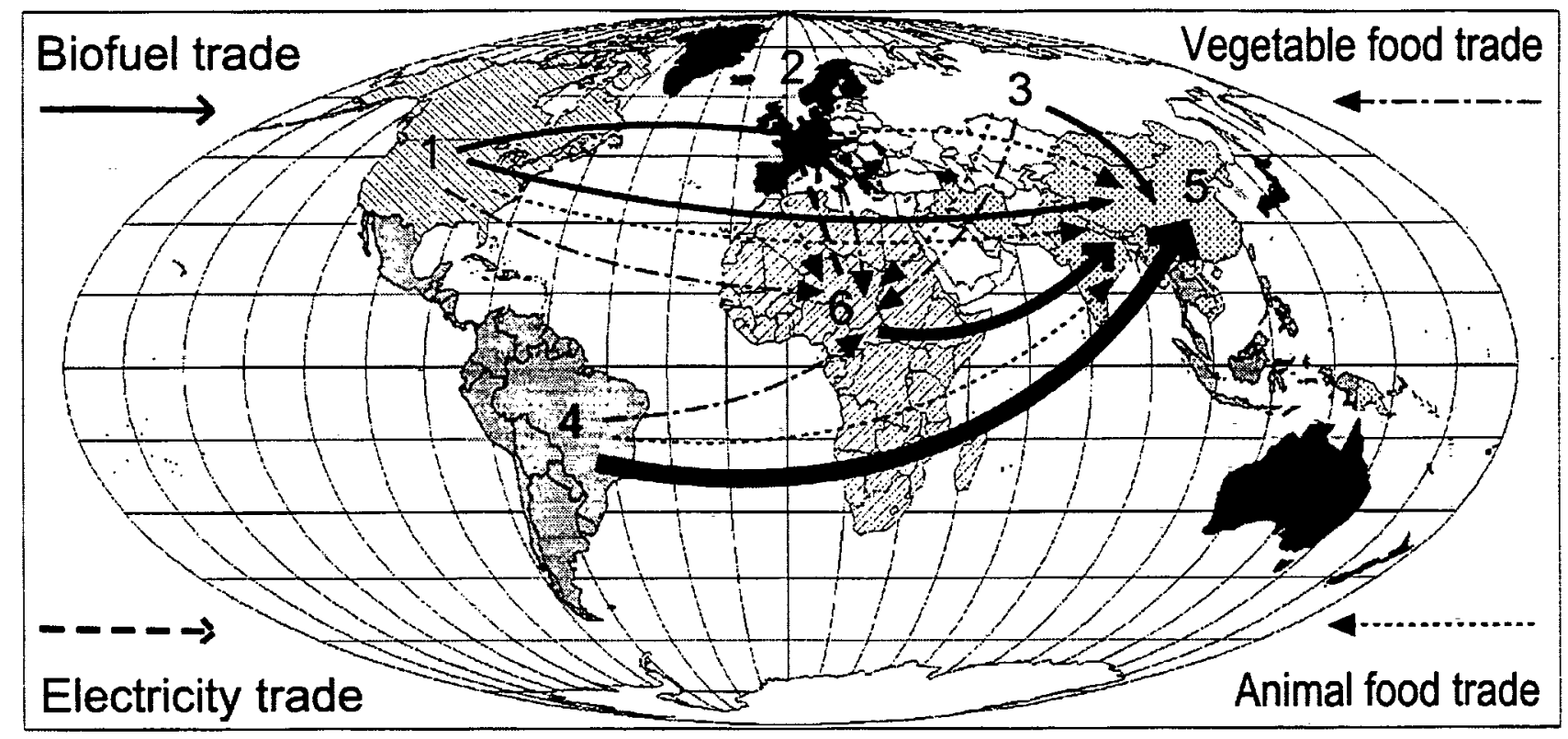

\section{Decentralised scenario for regions 1-6}

Figure 61. Patterns of food and energy trade in the decentralised 2050 scenario. The quantities of import and export are given in Figures 55-60. This Figure also shows the locations of the six regions, the individual countries belonging to each being listed in Appendix $\mathrm{A}$. 


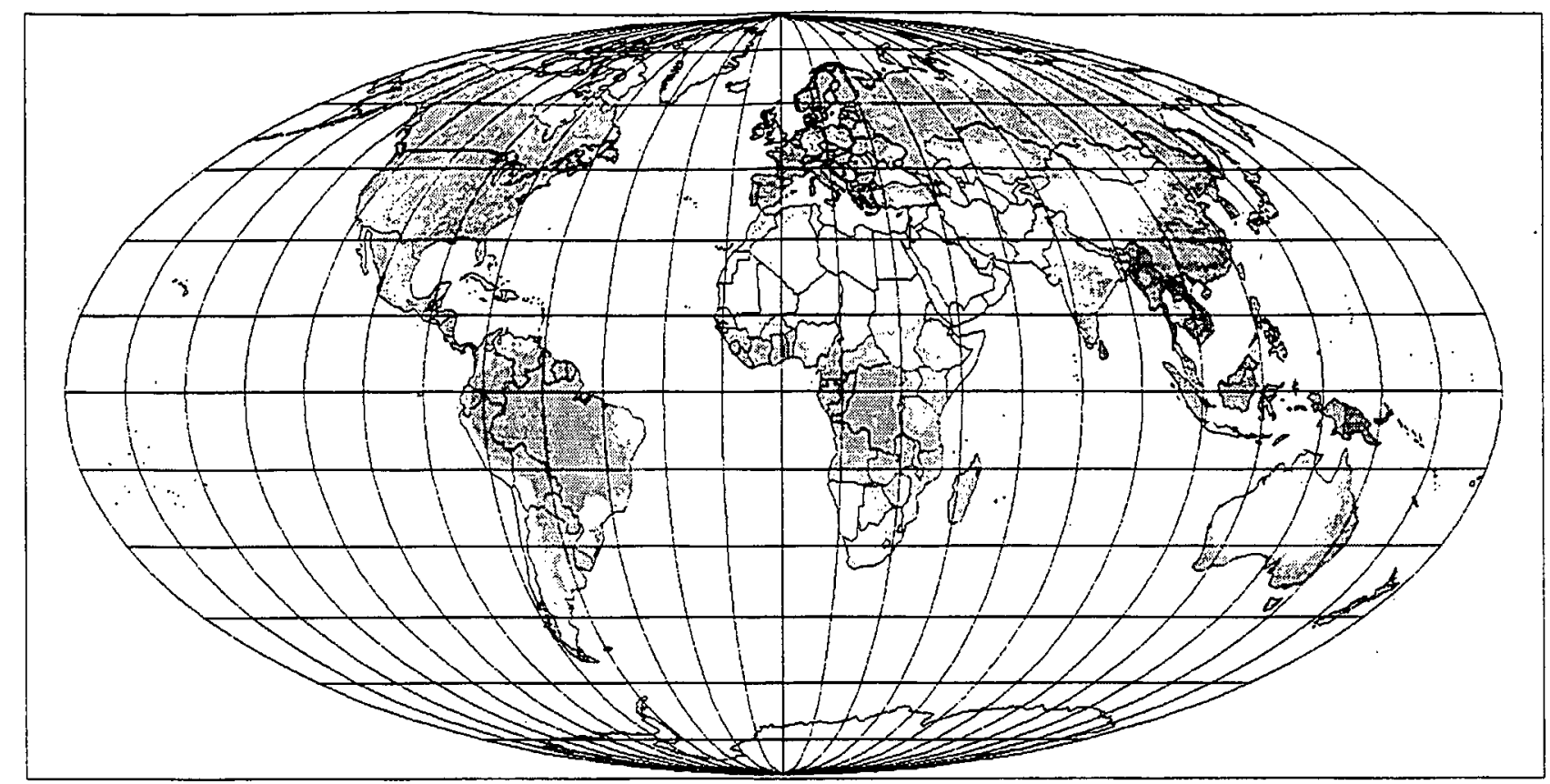

Figure 62. Local surplus of biofuel supplies (such as methanol) over demand for transportation fuels on an area basis, according to the centralised 2050 scenario. (annual average supply minus demand in $\mathrm{W} / \mathrm{m}^{2}$ is shown if positive; scale given in Figure $4 \mathrm{e}$ ).

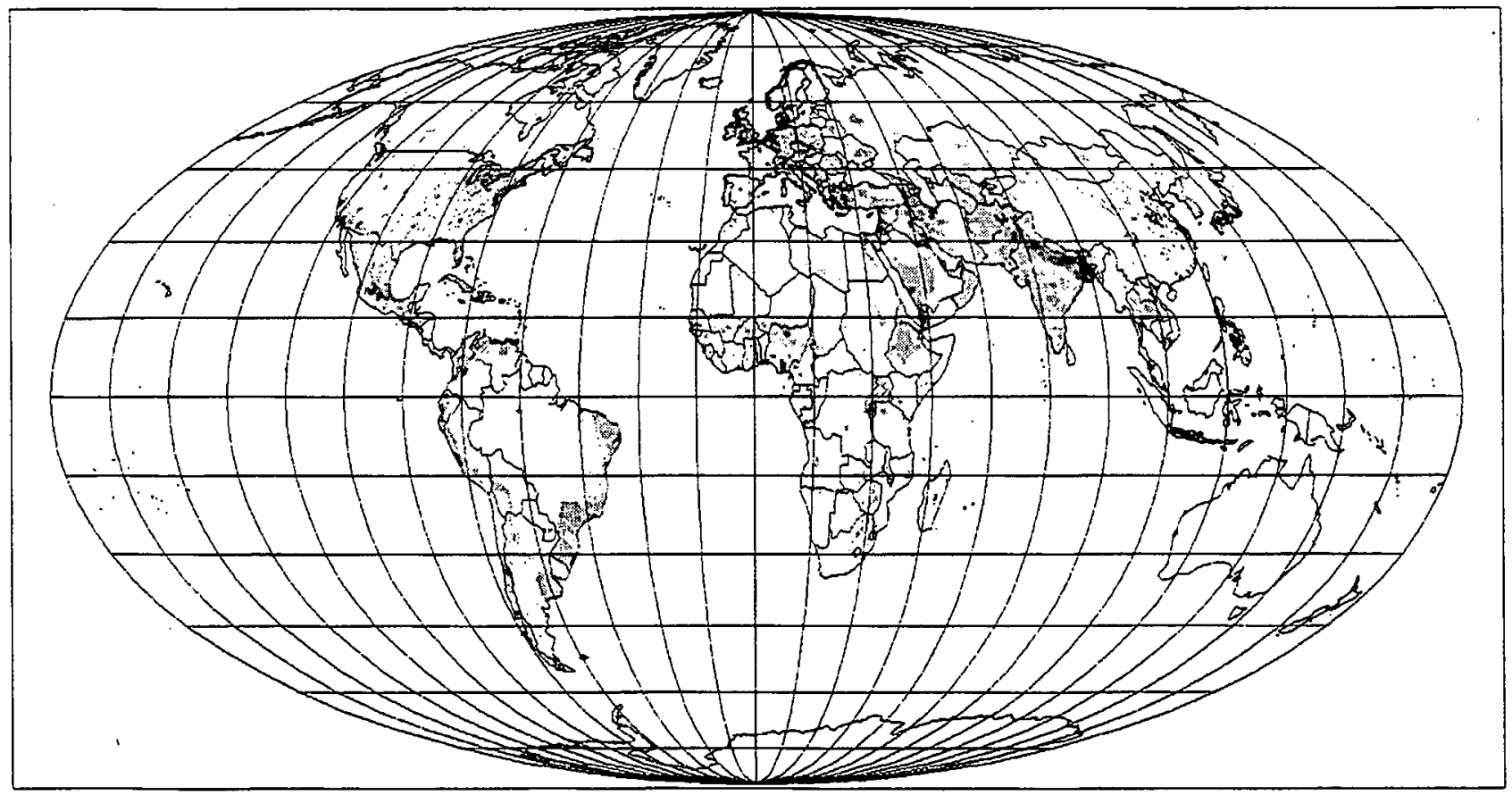

Figure 63. Local deficit of biofuel supplies (such as methanol) relative to demand for transportation fuels on an area basis, according to the centralised 2050 scenario. (annual average demand minus supply in $\mathrm{W} / \mathrm{m}^{2}$ is shown if positive; scale given in Figure $39 \mathrm{~b}$ ). 


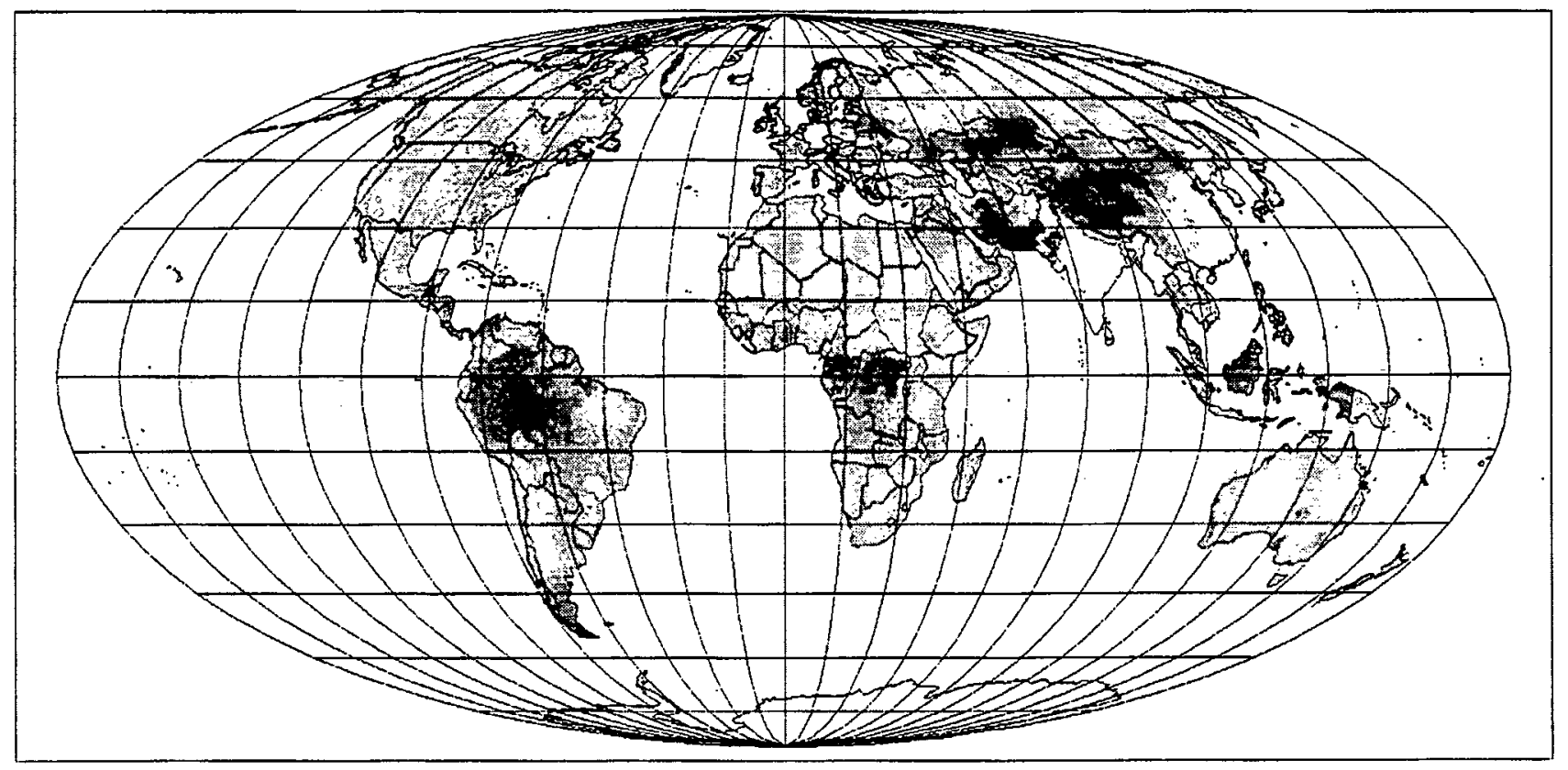

Figure 64. January local surplus of supplies of electricity and biofuels (such as biogas or hydrogen) over demand (all demand except food and transportation) on an area basis, according to the centralised 2050 scenario. (average supply minus demand in $\mathrm{W} / \mathrm{m}^{2}$ is shown if positive; scale given in Figure 4e).

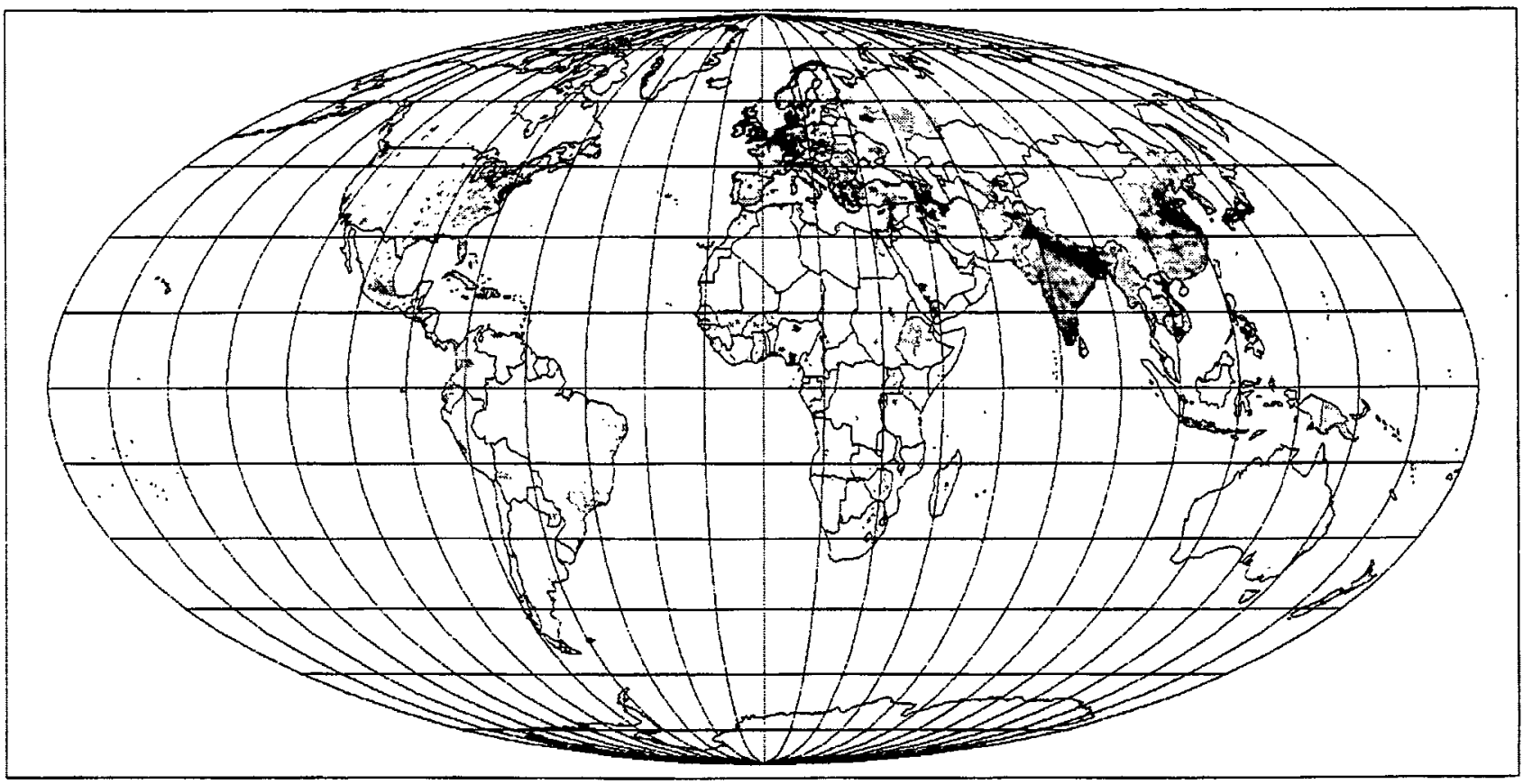

Figure 65. January local deficit of the supplies of electricity and biofuels (such as biogas or hydrogen) relative to demand (all demand except food and transportation) on an area basis, according to the centralised 2050 scenario. (average demand minus supply in W/m $\mathrm{m}^{2}$ is shown if positive; scale given in Figure 39b). 


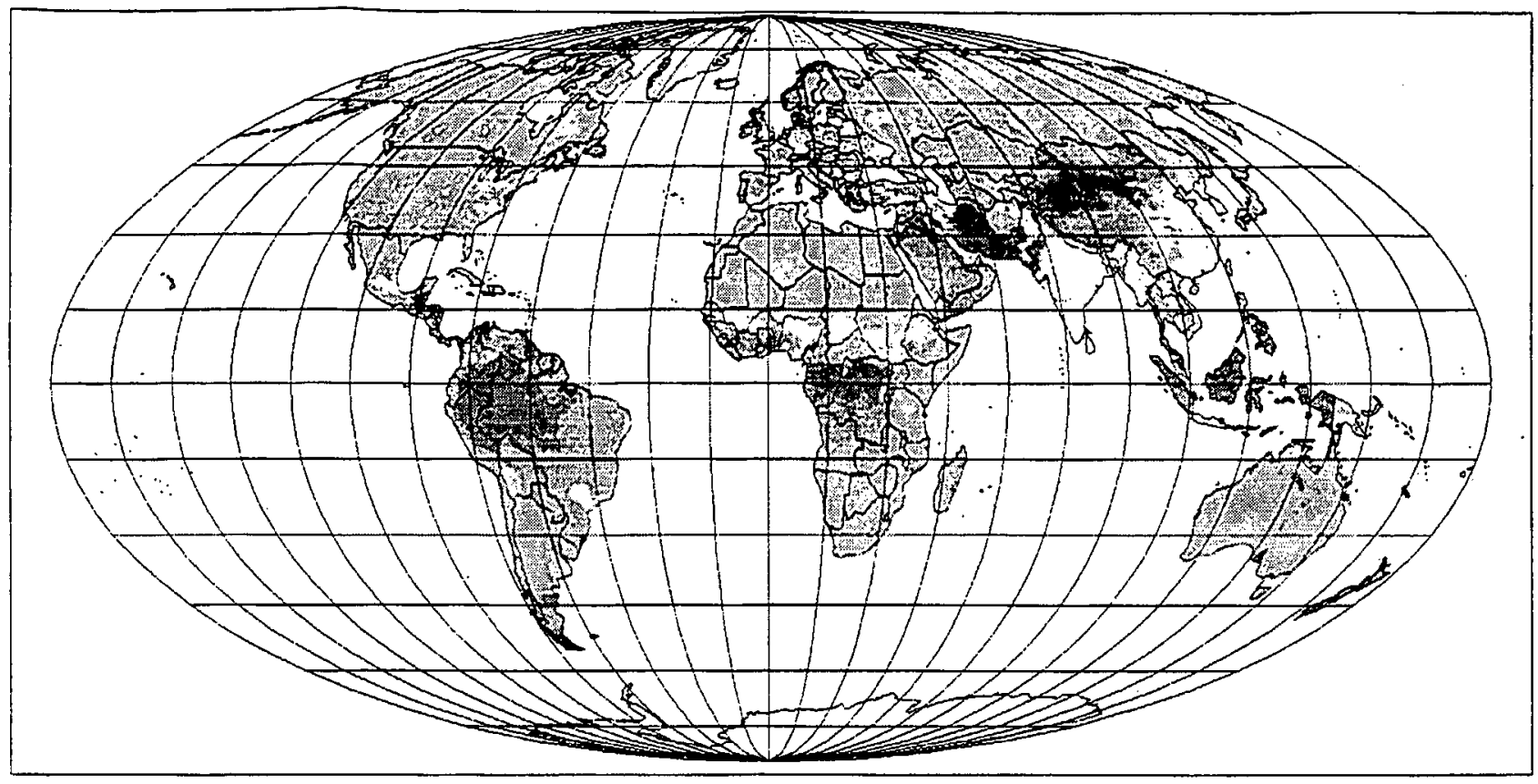

Figure 66. April local surplus of supplies of electricity and biofuels (such as biogas or hydrogen) over demand (all demand except food and transportation) on an area basis, according to the centralised 2050 scenario. (average supply minus demand in $\mathrm{W} / \mathrm{m}^{2}$ is shown if positive; scale given in Figure 4e).

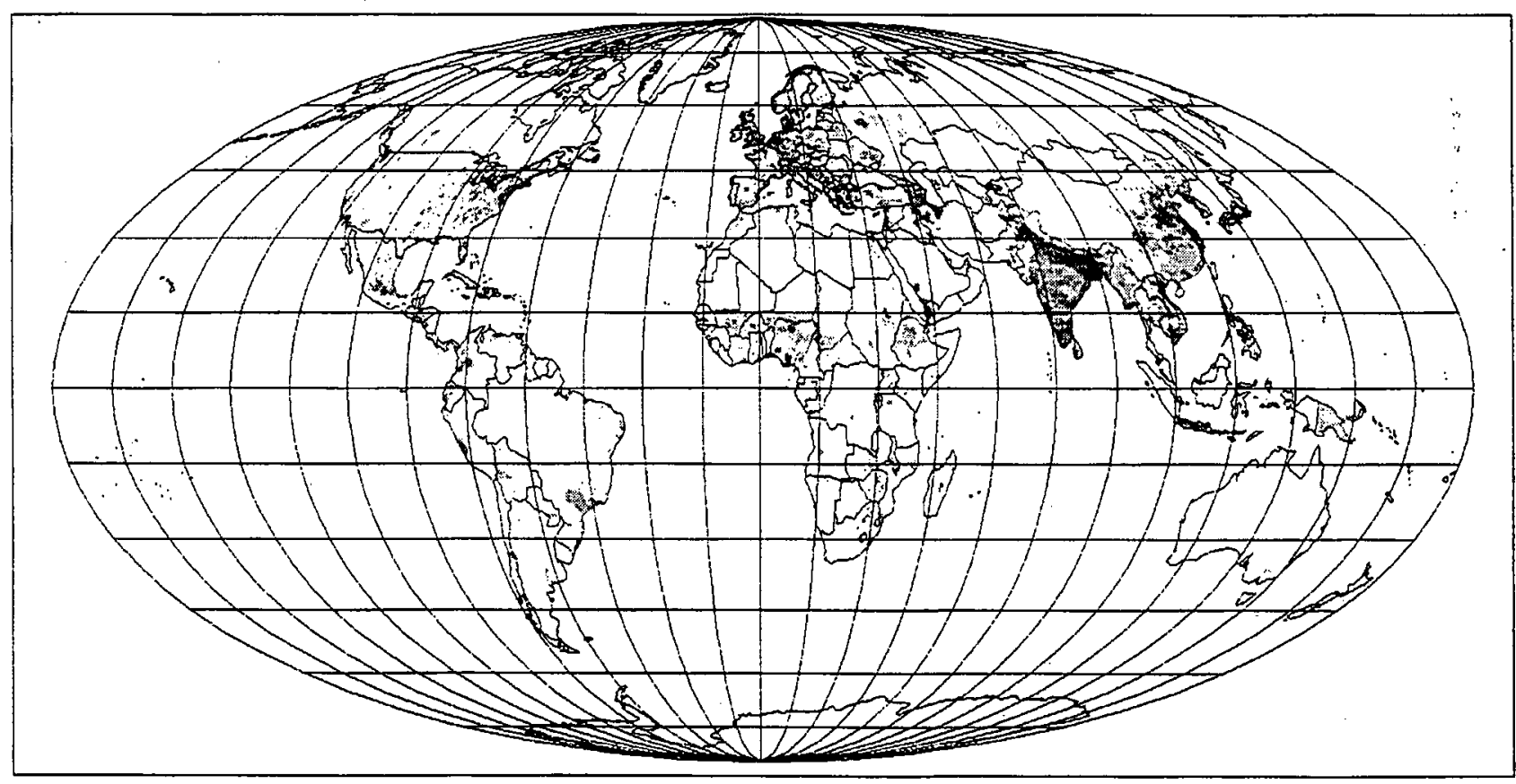

Figure 67. April local deficit of the supplies of electricity and biofuels (such as biogas or hydrogen) relative to demand (all demand except food and transportation) on an area basis, according to the centralised 2050 scenario. (average demand minus supply in $\mathrm{W} / \mathrm{m}^{2}$ is shown if positive; scale given in Figure 39b). 


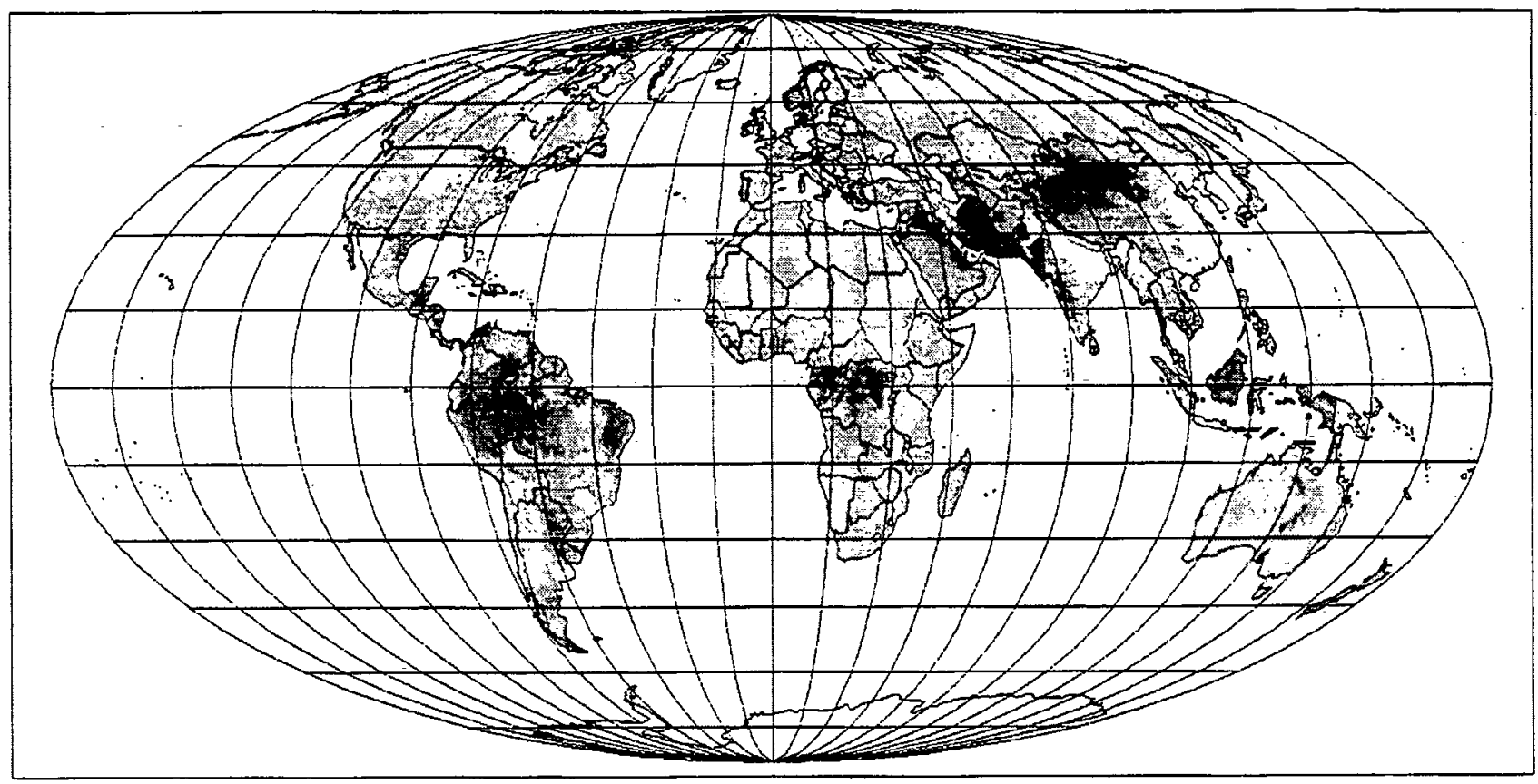

Figure 68. July local surplus of supplies of electricity and biofuels (such as biogas or hydrogen) over demand (all demand except food and transportation) on an area basis, according to the centralised 2050 scenario. (average supply minus demand in $\mathrm{W} / \mathrm{m}^{2}$ is shown if positive; scale given in Figure 4e).

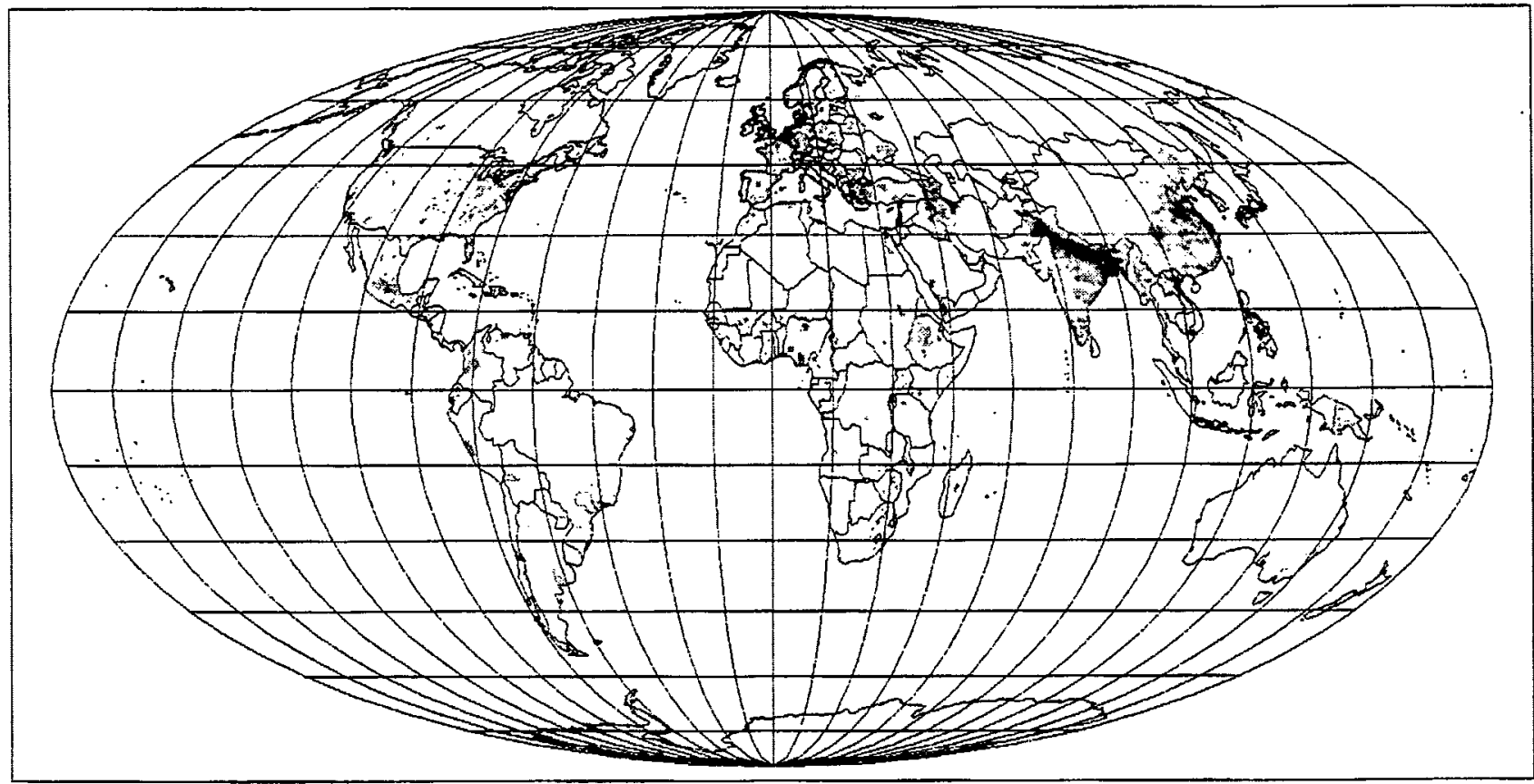

Figure 69. July local deficit of the supplies of electricity and biofuels (such as biogas or hydrogen) relative to demand (all demand except food and transportation) on an area basis, according to the centralised 2050 scenario. (average demand minus supply in $\mathrm{W} / \mathrm{m}^{2}$ is shown if positive; scale given in Figure 39b). 


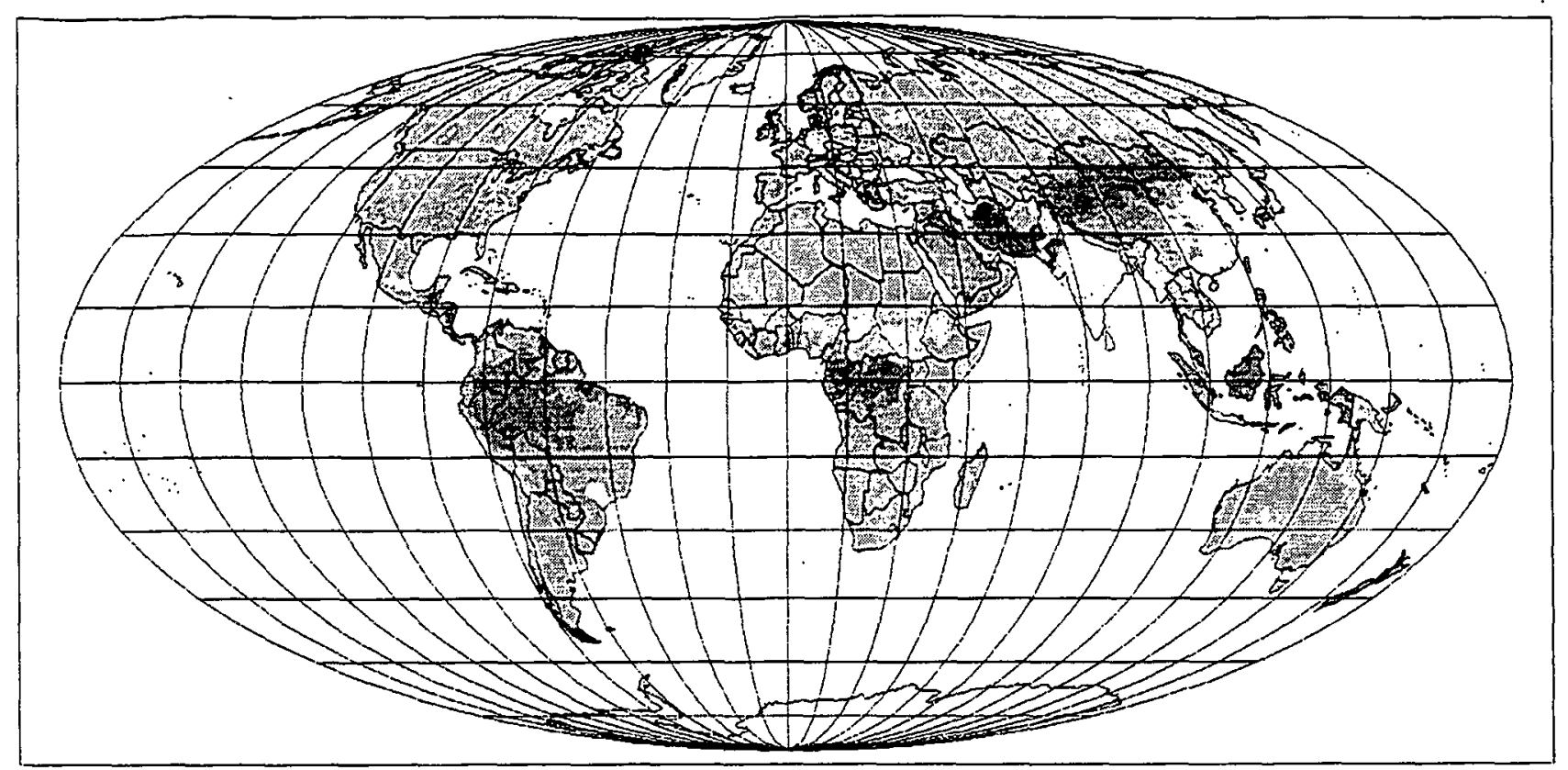

Figure 70. October local surplus of supplies of electricity and biofuels (such as biogas or hydrogen) over demand (all demand except food and transportation) on an area basis, according to the centralised 2050 scenario. (average supply minus demand in $\mathrm{W} / \mathrm{m}^{2}$ is shown if positive; scale given in Figure 4e).

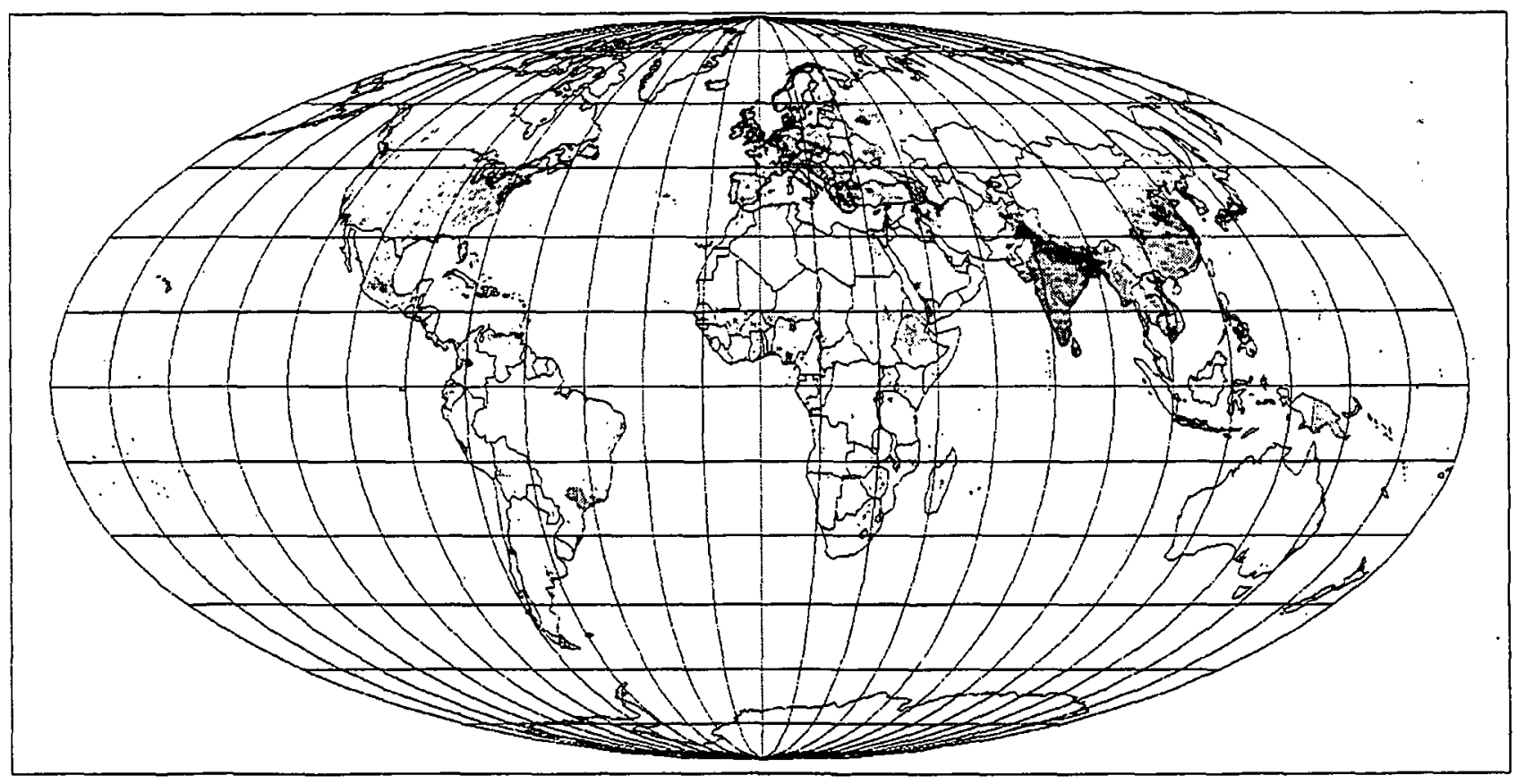

Figure 71. October local deficit of the supplies of electricity and biofuels (such as biogas or hydrogen) relative to demand (all demand except food and transportation) on an area basis, according to the centralised 2050 scenario. (average demand minus supply in W/m $\mathrm{m}^{2}$ is shown if positive; scale given in Figure 39b). 


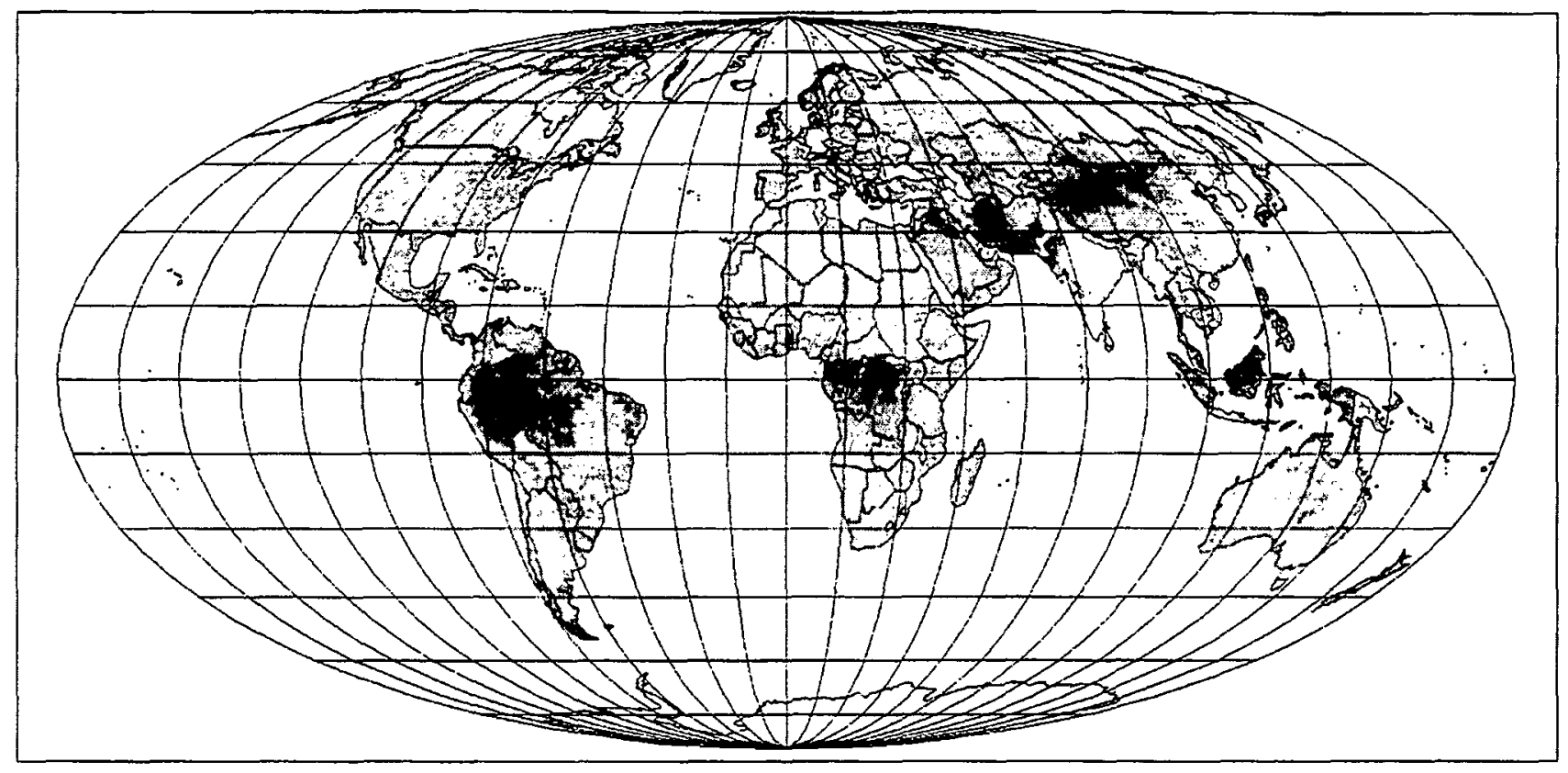

Figure 72. Annual average local surplus of supplies of electricity and biofuels (such as biogas or hydrogen) over demand (all demand except food and transportation) on an area basis, according to the centralised 2050 scenario. (average supply minus demand in $\mathrm{W} / \mathrm{m}^{2}$ is shown if positive; scale given in Figure 4e).

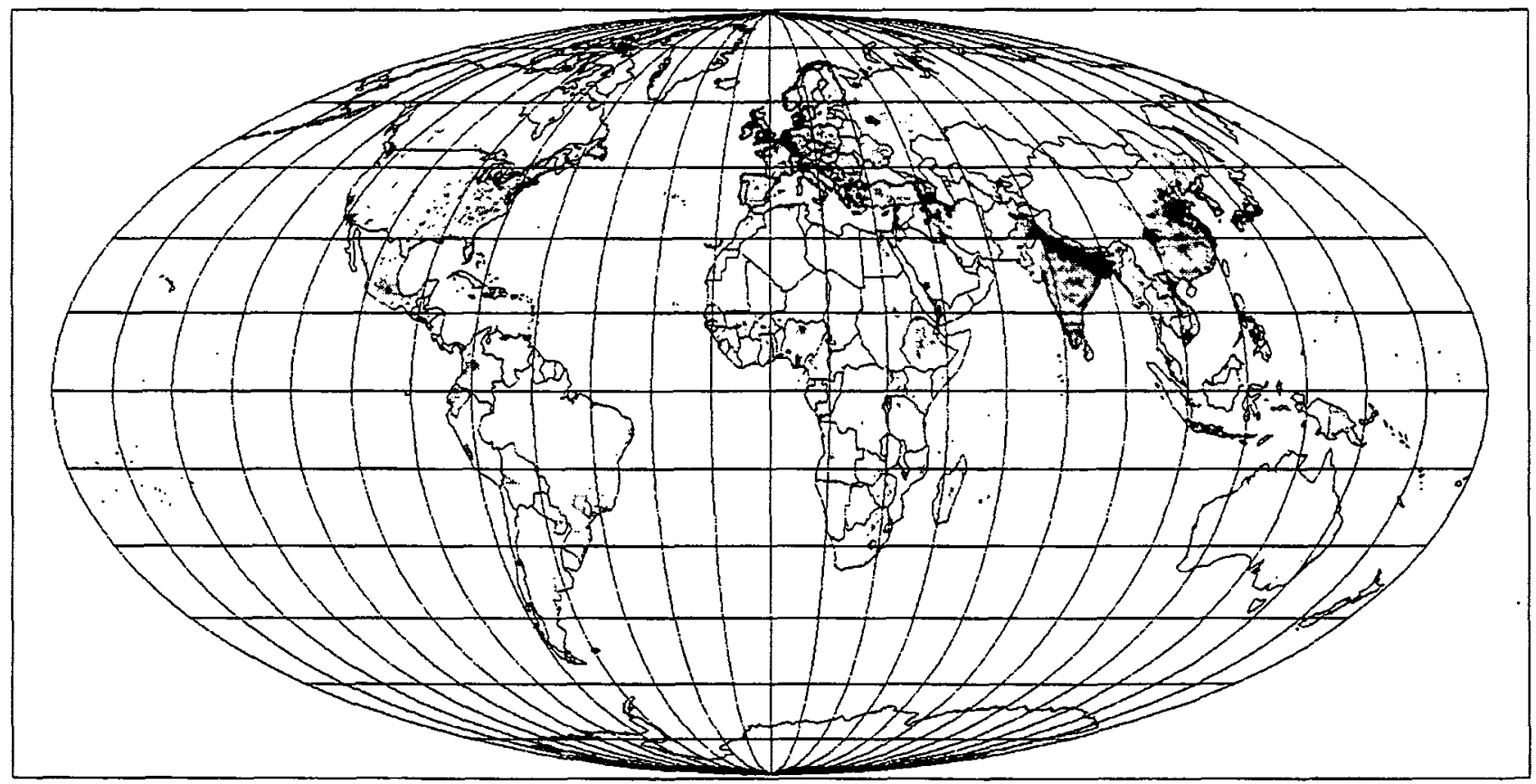

Figure 73. Annual average local deficit of the supplies of electricity and biofuels (such as biogas or hydrogen) relative to demand (all demand except food and transportation) on an area basis, according to the centralised 2050 scenario. (average demand minus supply in W/m shown if positive; scale given in Figure $39 \mathrm{~b}$ ). 


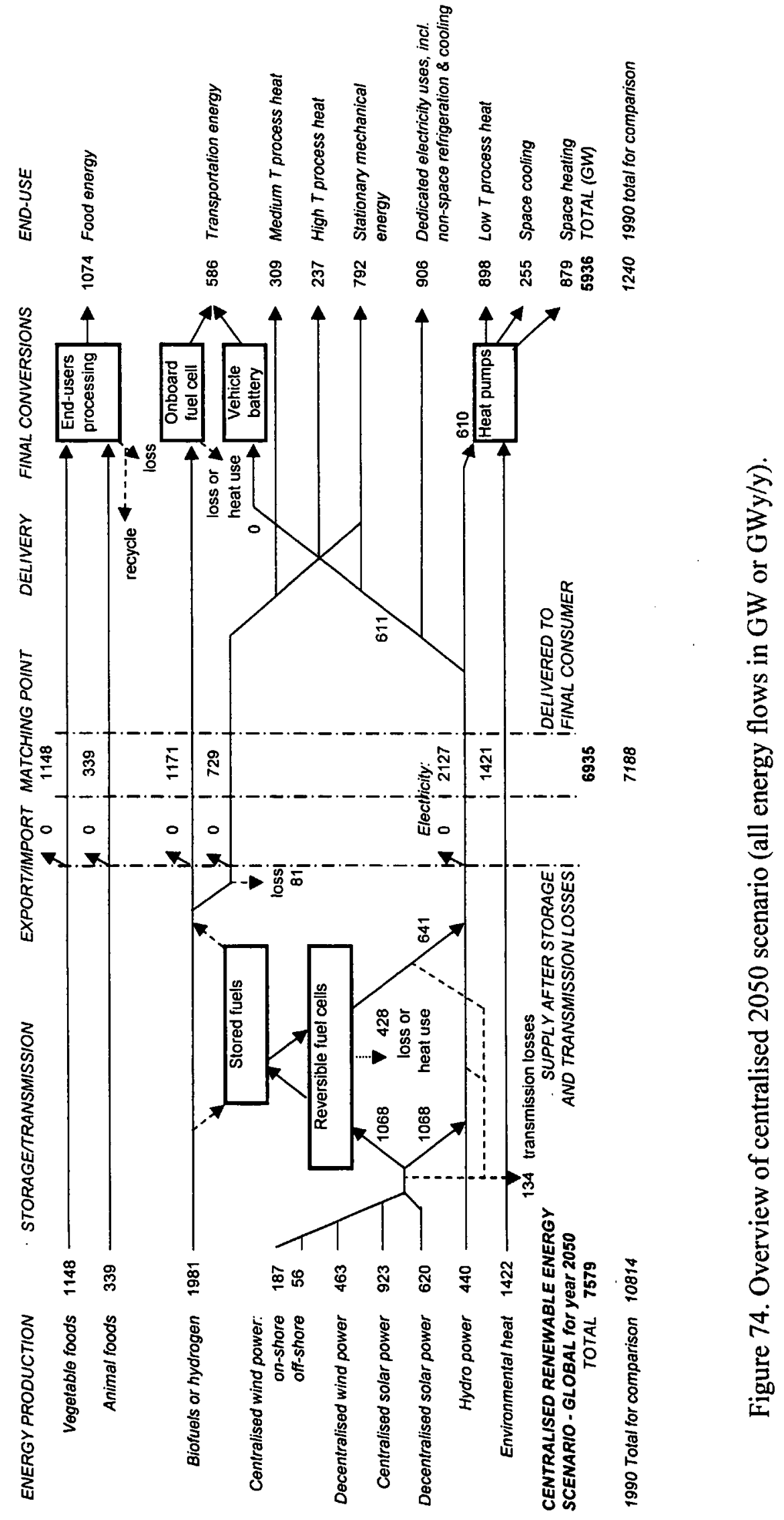




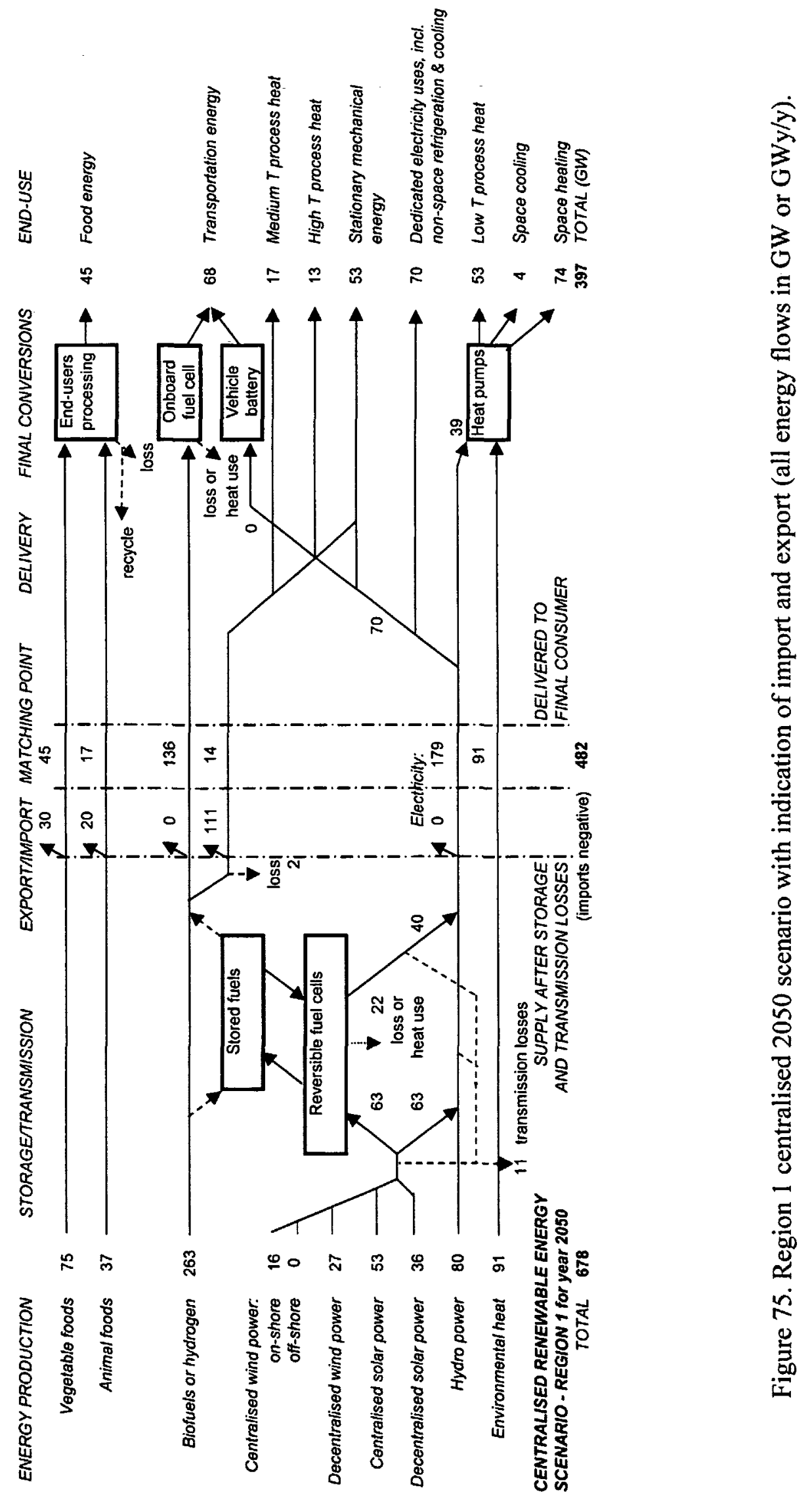




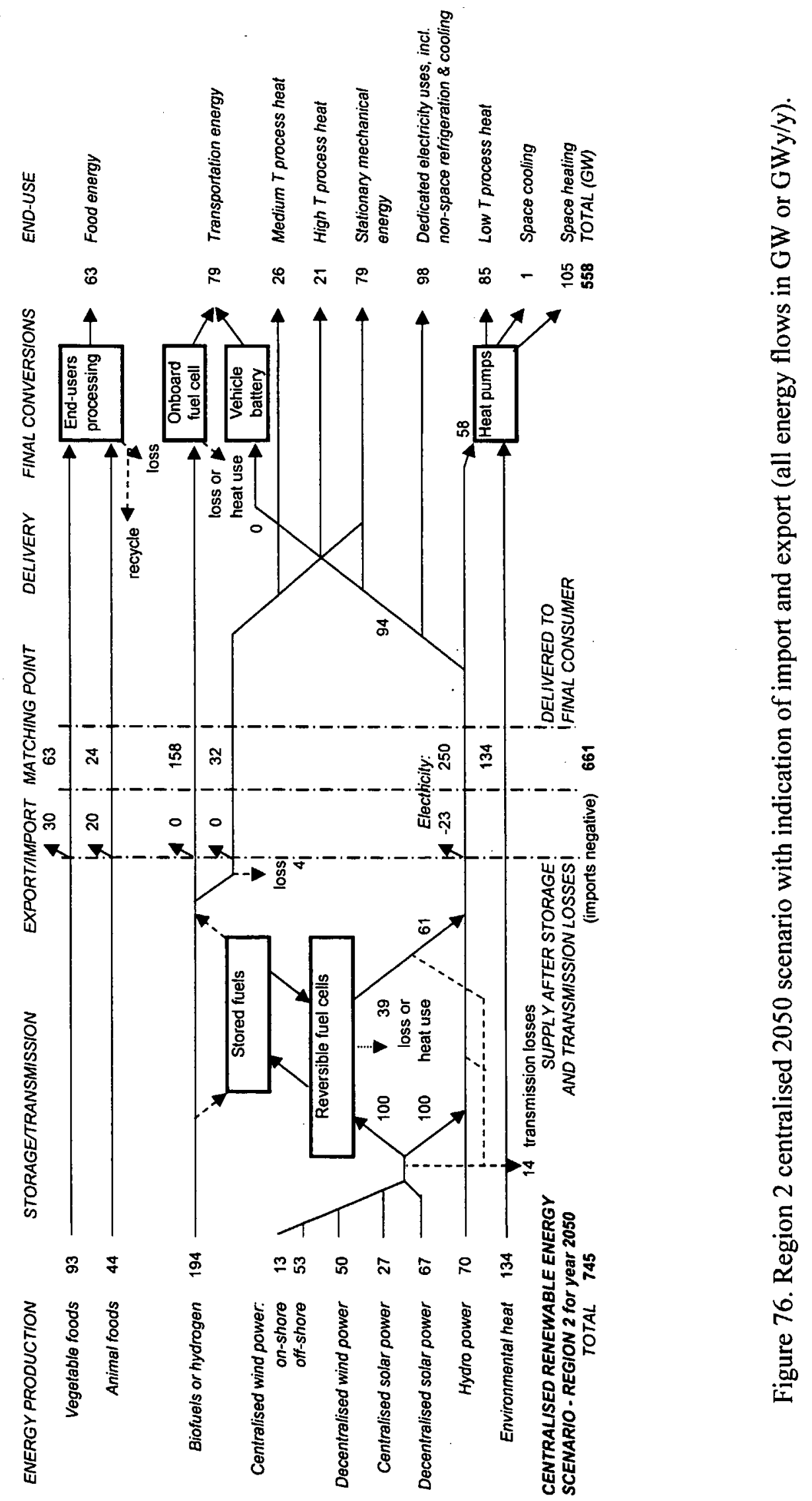




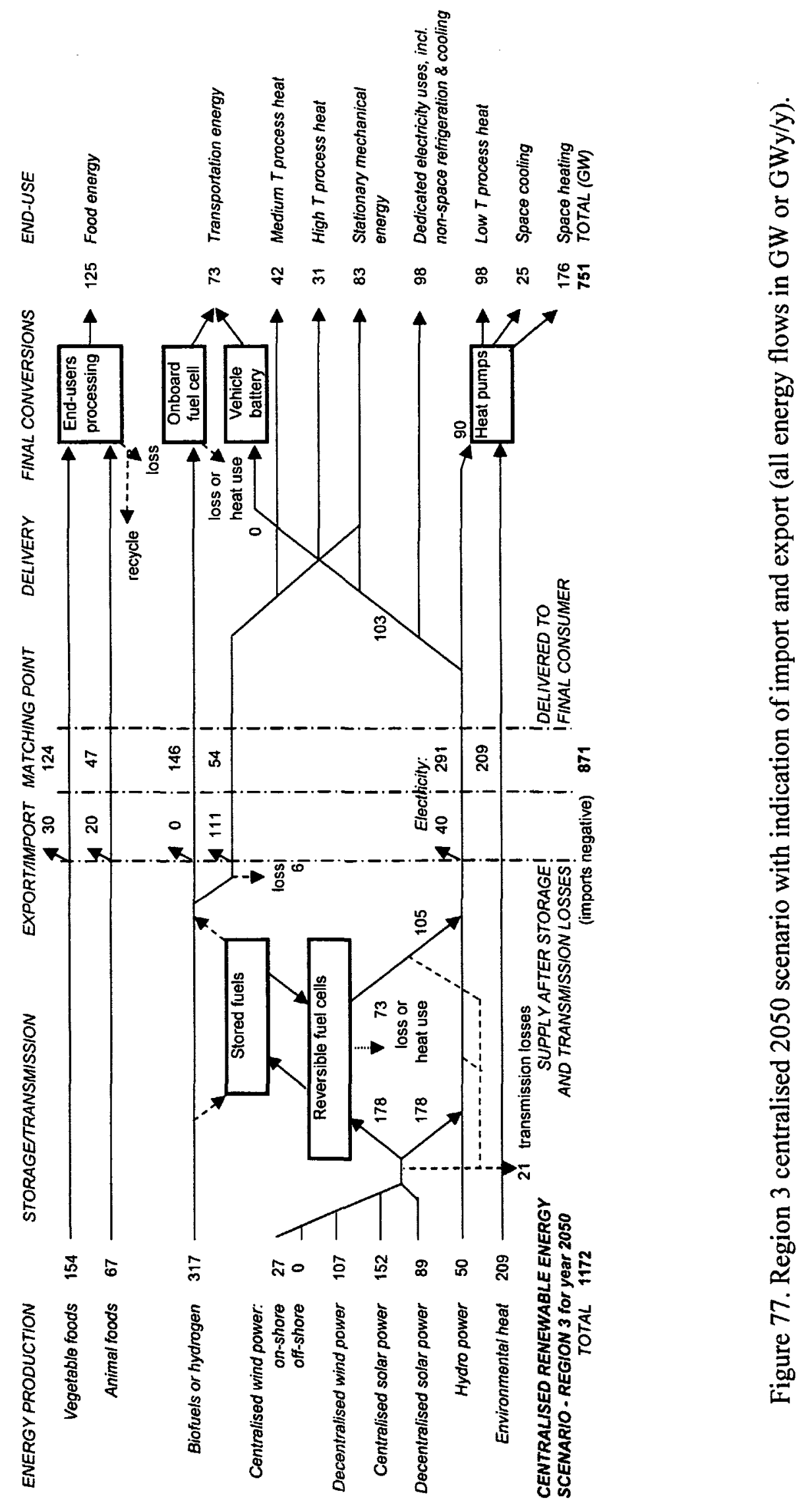




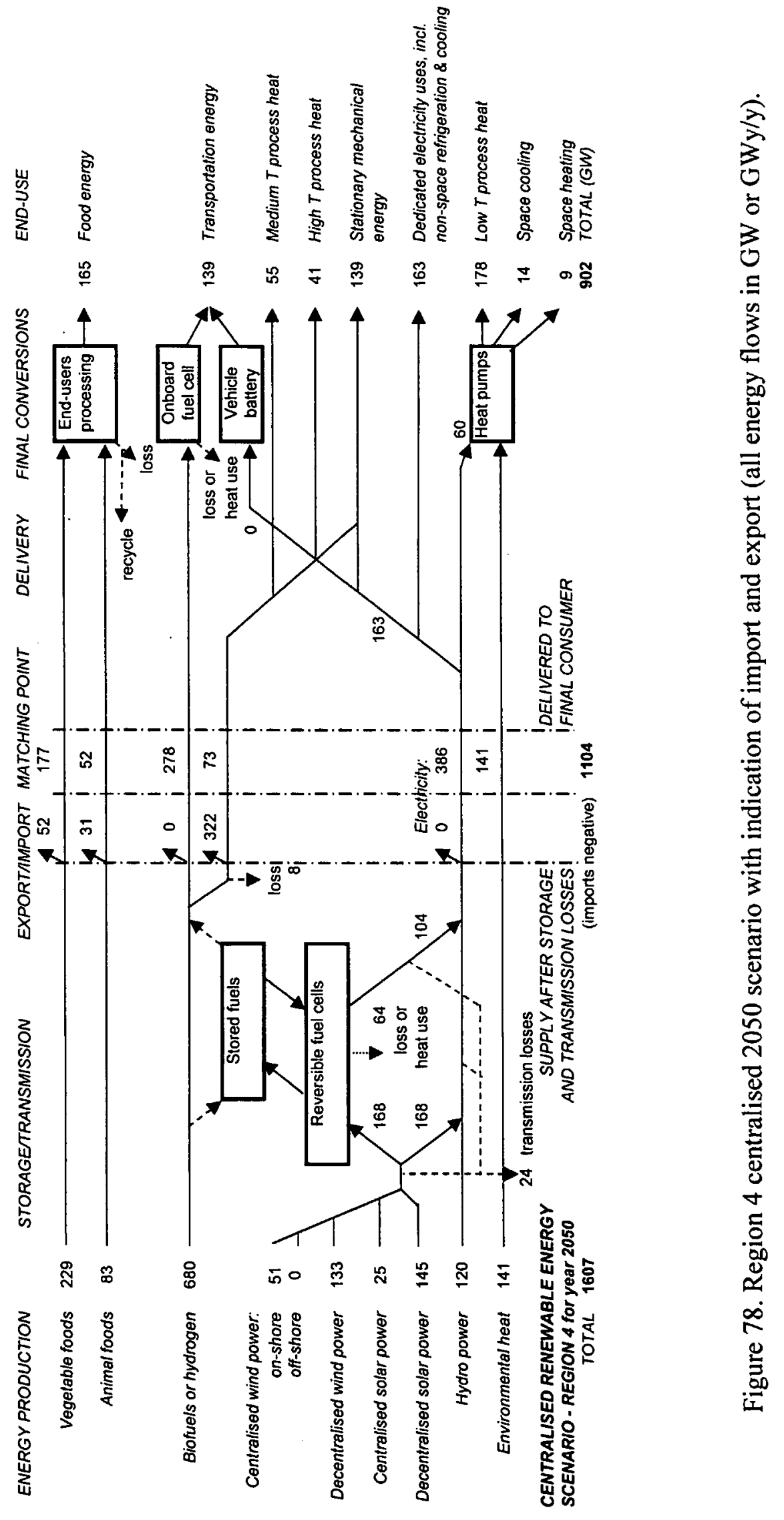




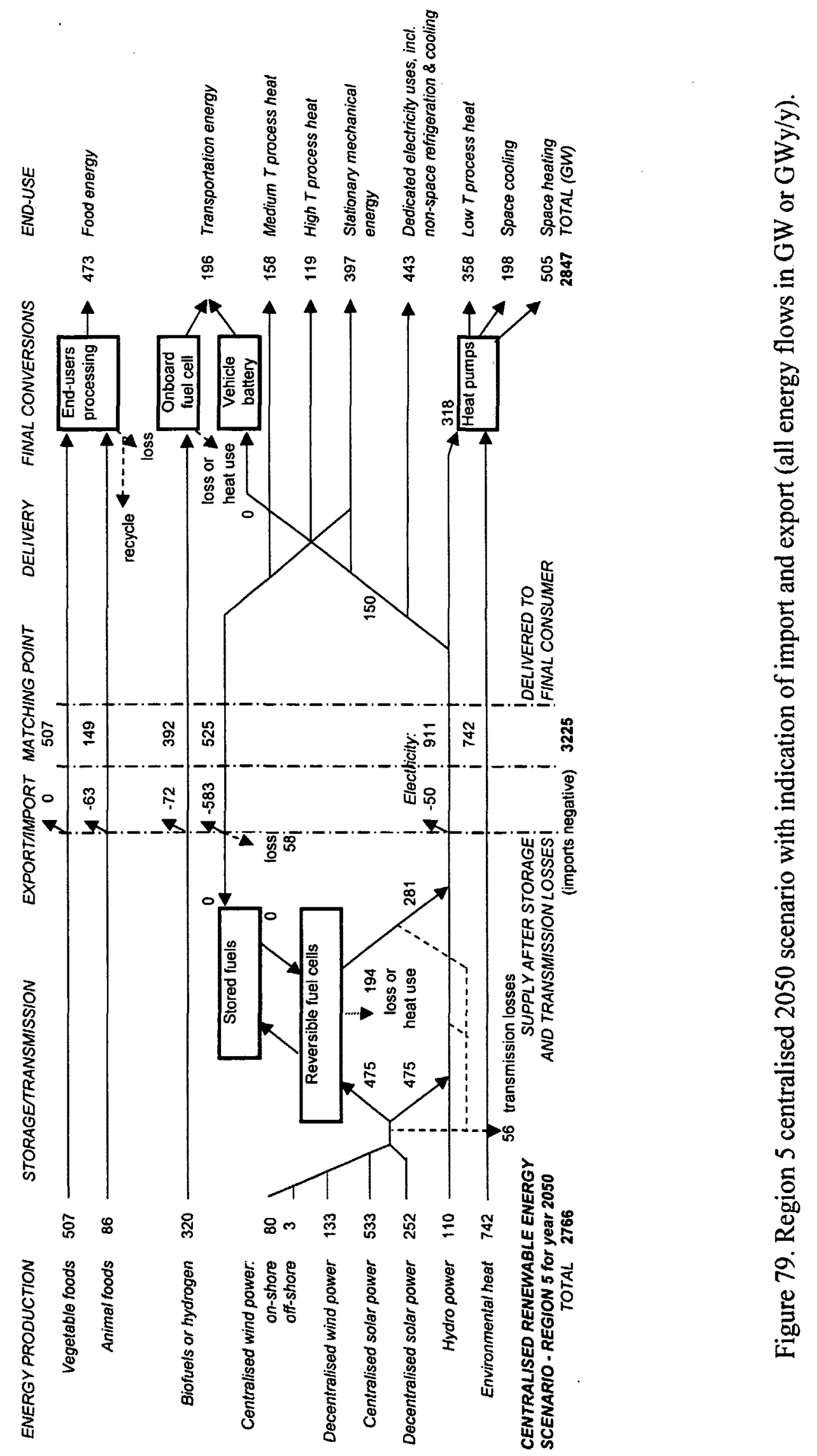




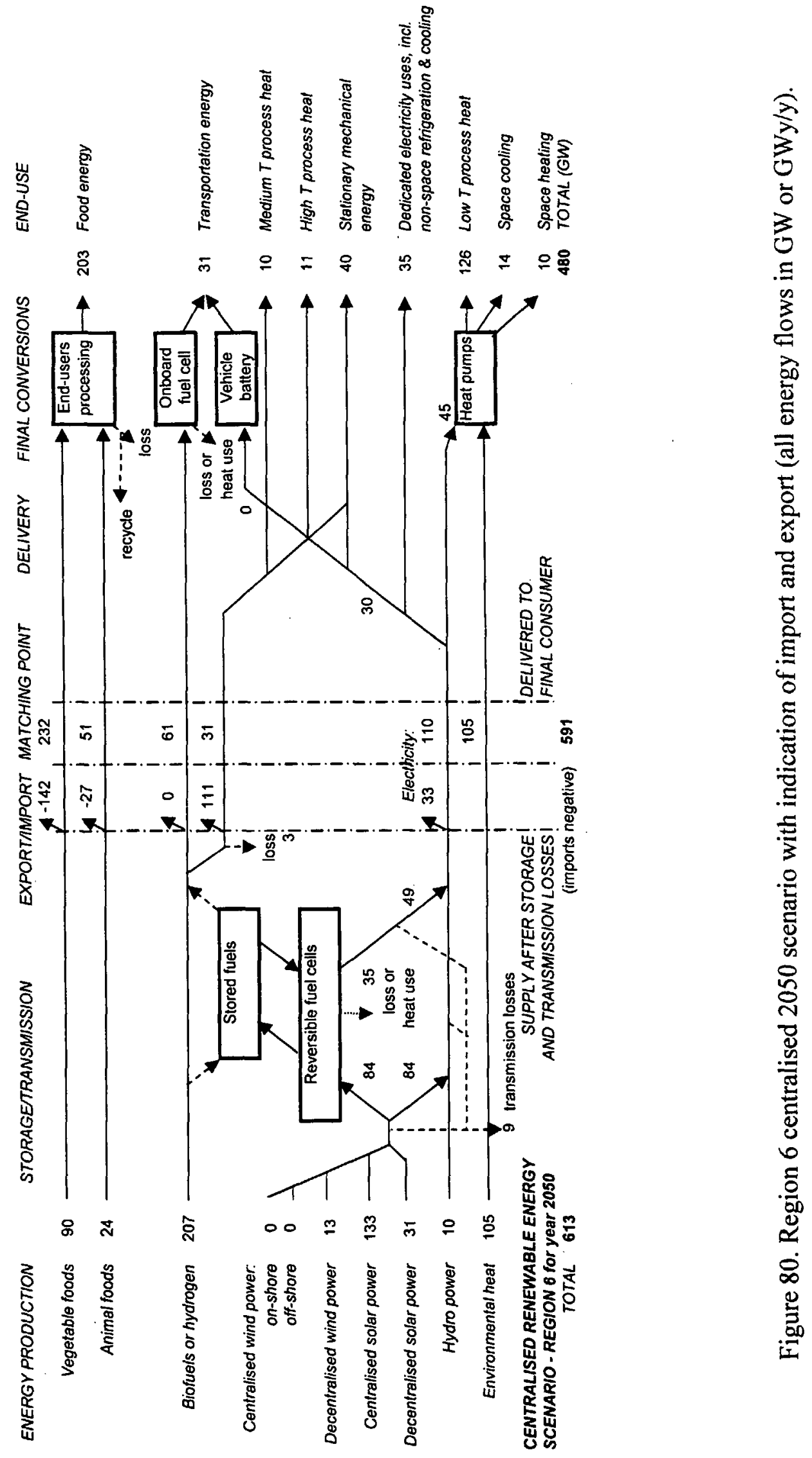




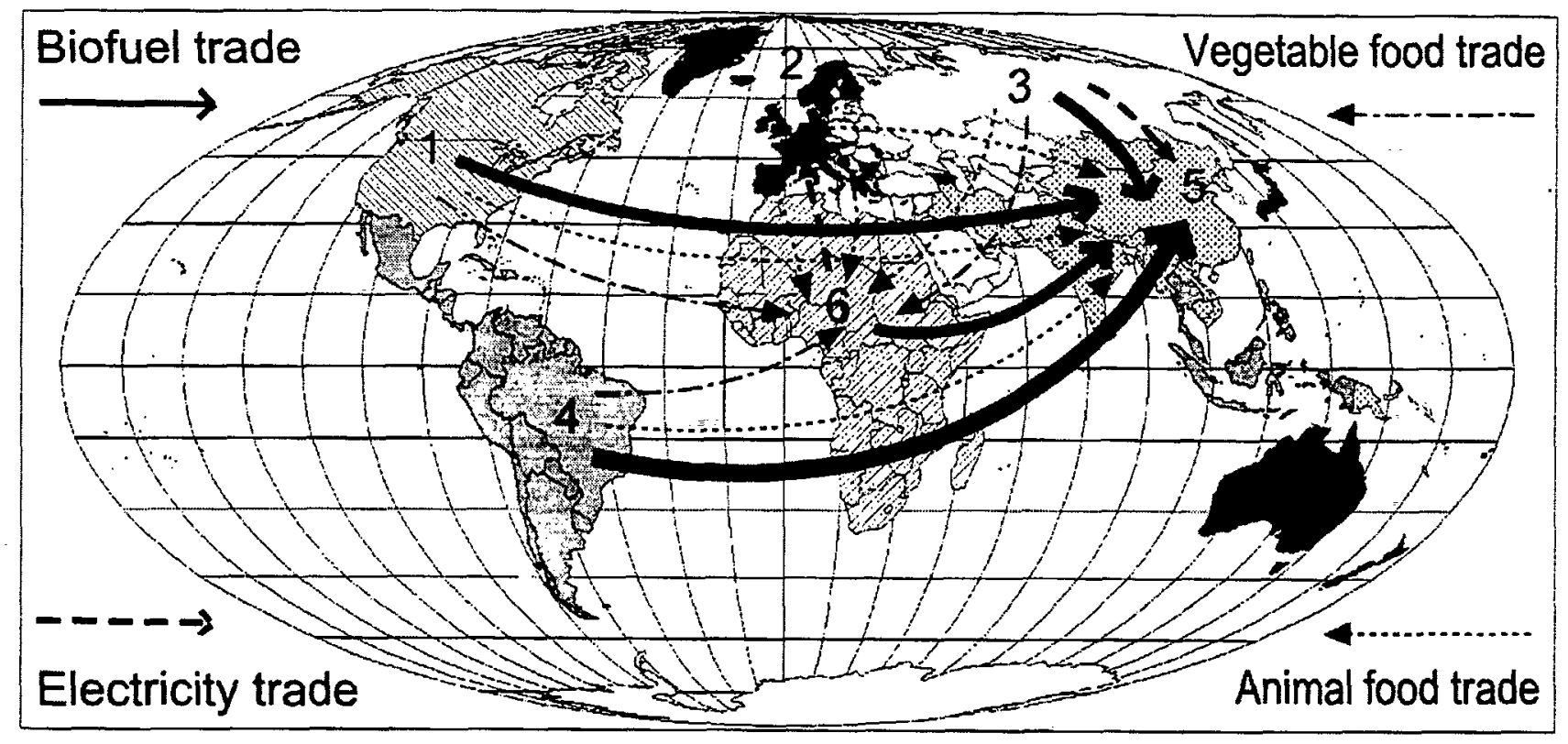

\section{Centralised scenario for regions 1-6}

Figure 81. Patterns of food and energy trade in the centralised 2050 scenario. The quantities of import and export are given in Figures 75-80. This Figure also shows the locations of the six regions, the individual countries belonging to each being listed in Appendix A. 


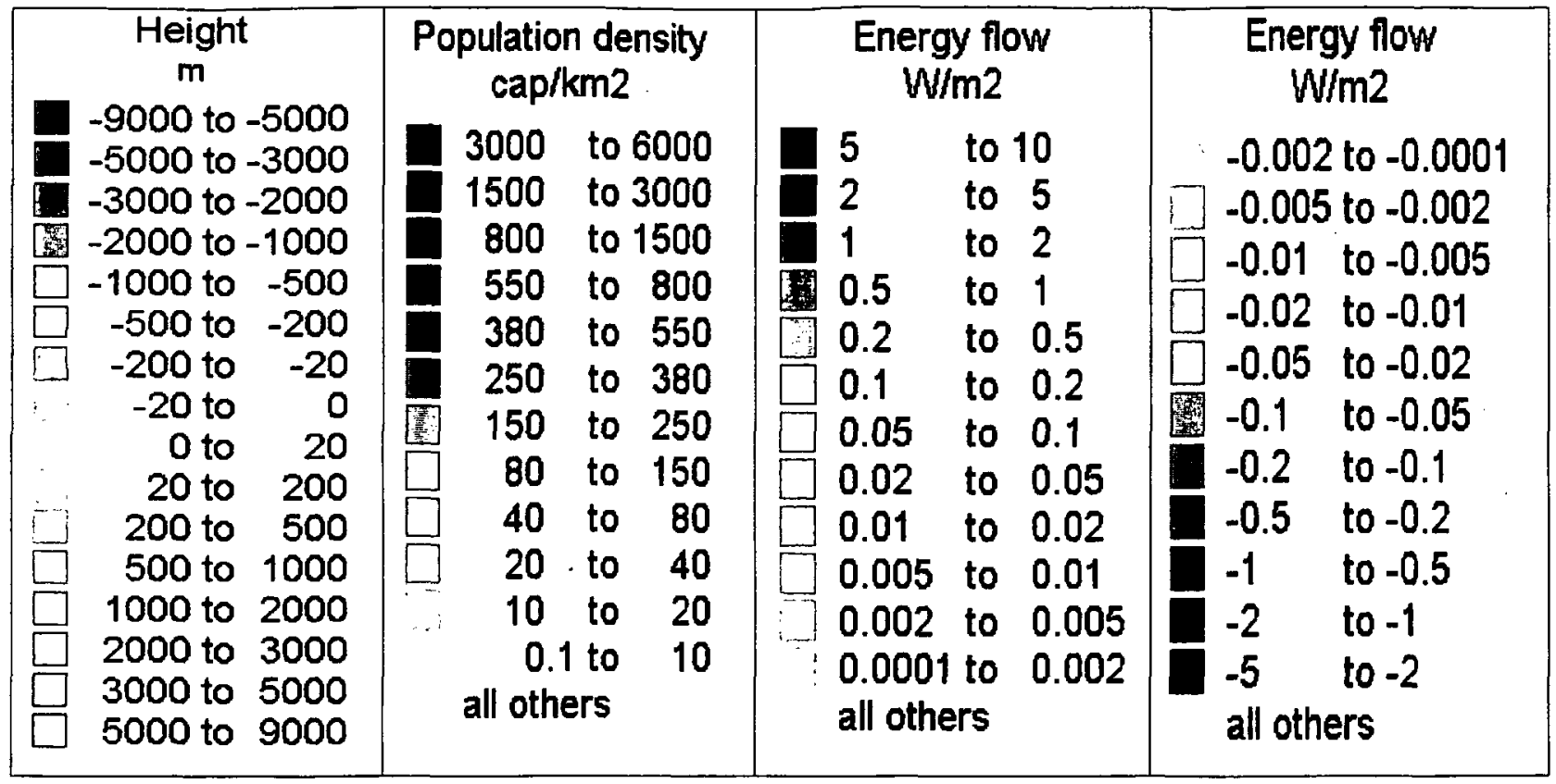

Figure 12b. Height scale relative to mean sea level (metres)

Figure 1b: Population scale (people per $\mathrm{km}^{2}$, note that the scale is not linear)

Figure 4e. Scale of energy flow (rate of energy capture, conversion or use, note that the scale is logarithmic $)\left(\mathrm{W} / \mathrm{m}^{2}\right)$.

Figure $39 \mathrm{~b}$. Scale of negative energy flows (such as deficit in rate of supply relative to demand; note that scale is logarithmic and similar to scale of positive energy flows shown in Figure 4e; unit: $\mathrm{W} / \mathrm{m}^{2}$ ).

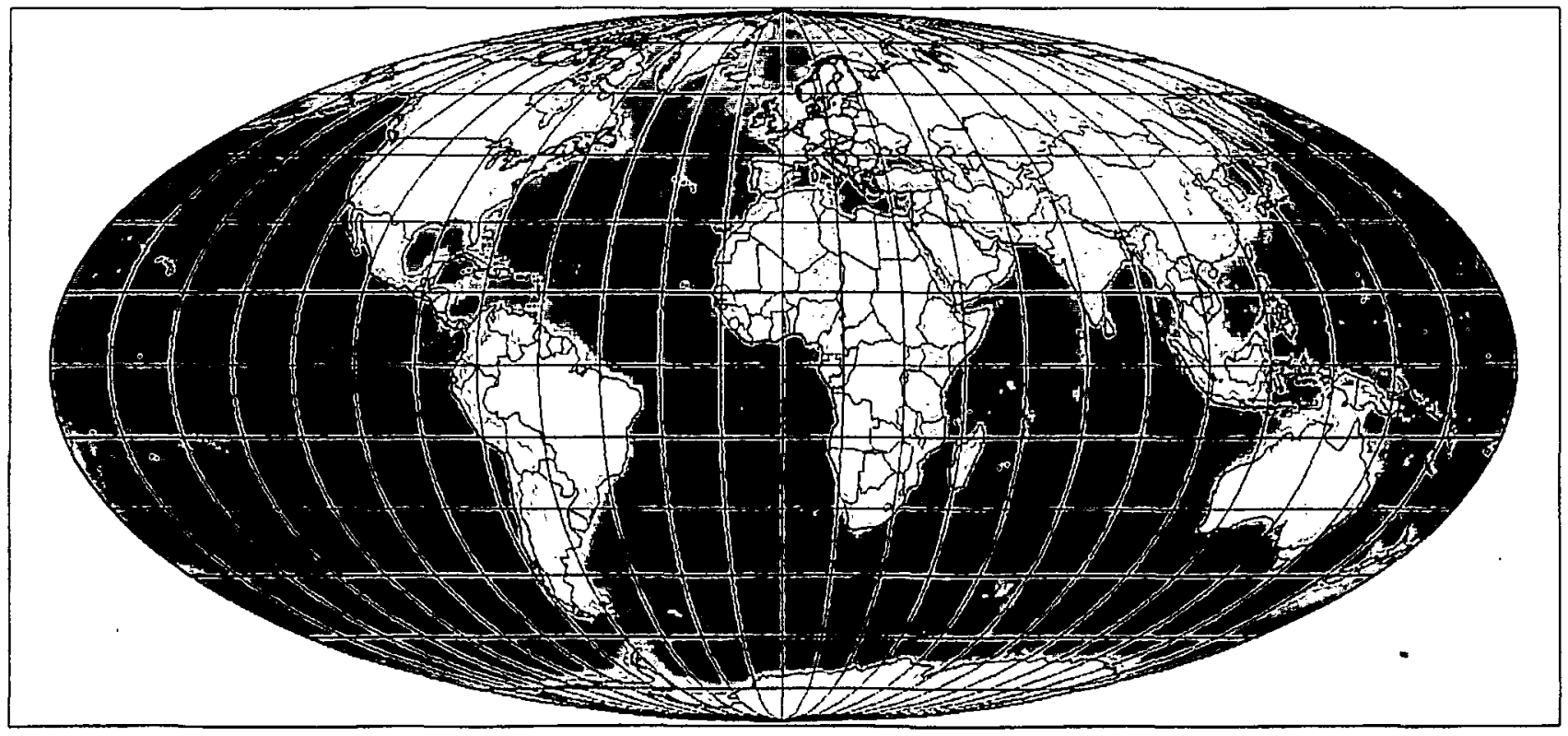

Figure 12a. Land and ocean topography (based on data from Sandwell et al., 1998) (scale given in Figure 12b). 


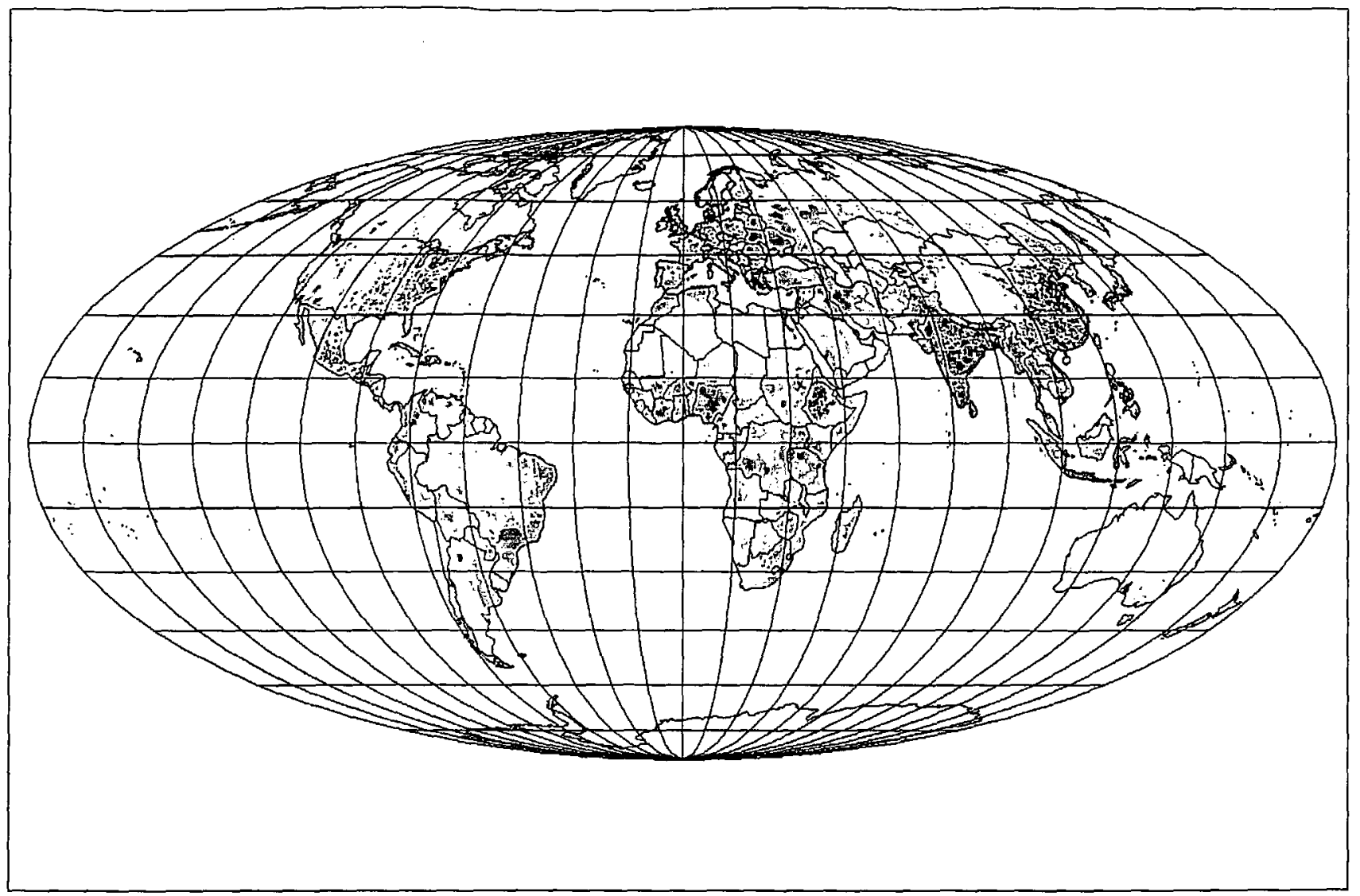

Figure 1a: Present population density: 1994 data (source: CIESIN, 1997; scale given in Figure 1b). This and all following geographical maps are employing the Mollweide equal area projection, consistent with our rendering of area-based densities of various quantities. This means that visual summing up over or comparison between different regions will be correct, in contrast to the situation for e.g. longitude-latitude square grids.

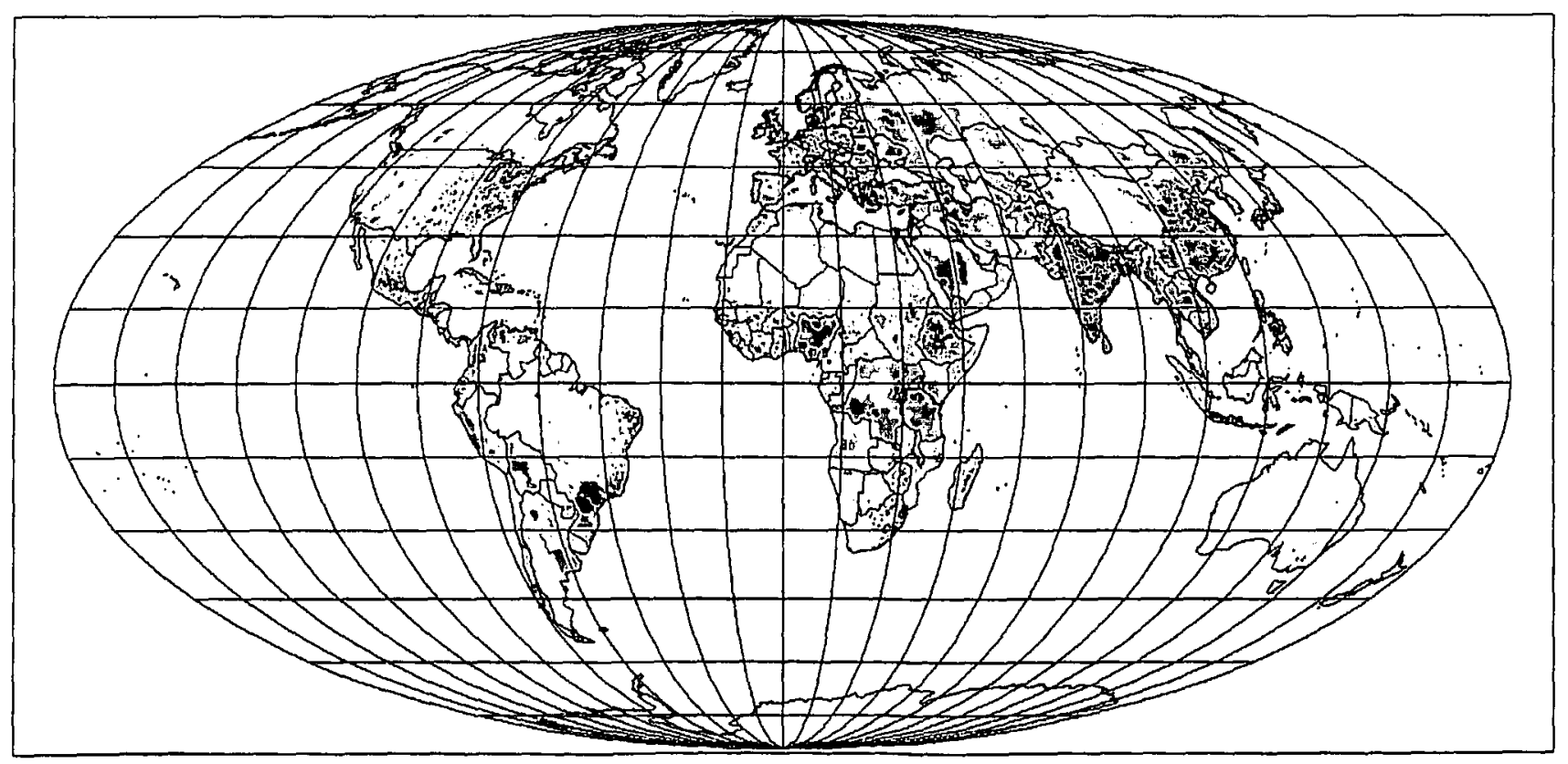

Figure 2. Population density assumed in 2050 (scale given in Figure 1b). 


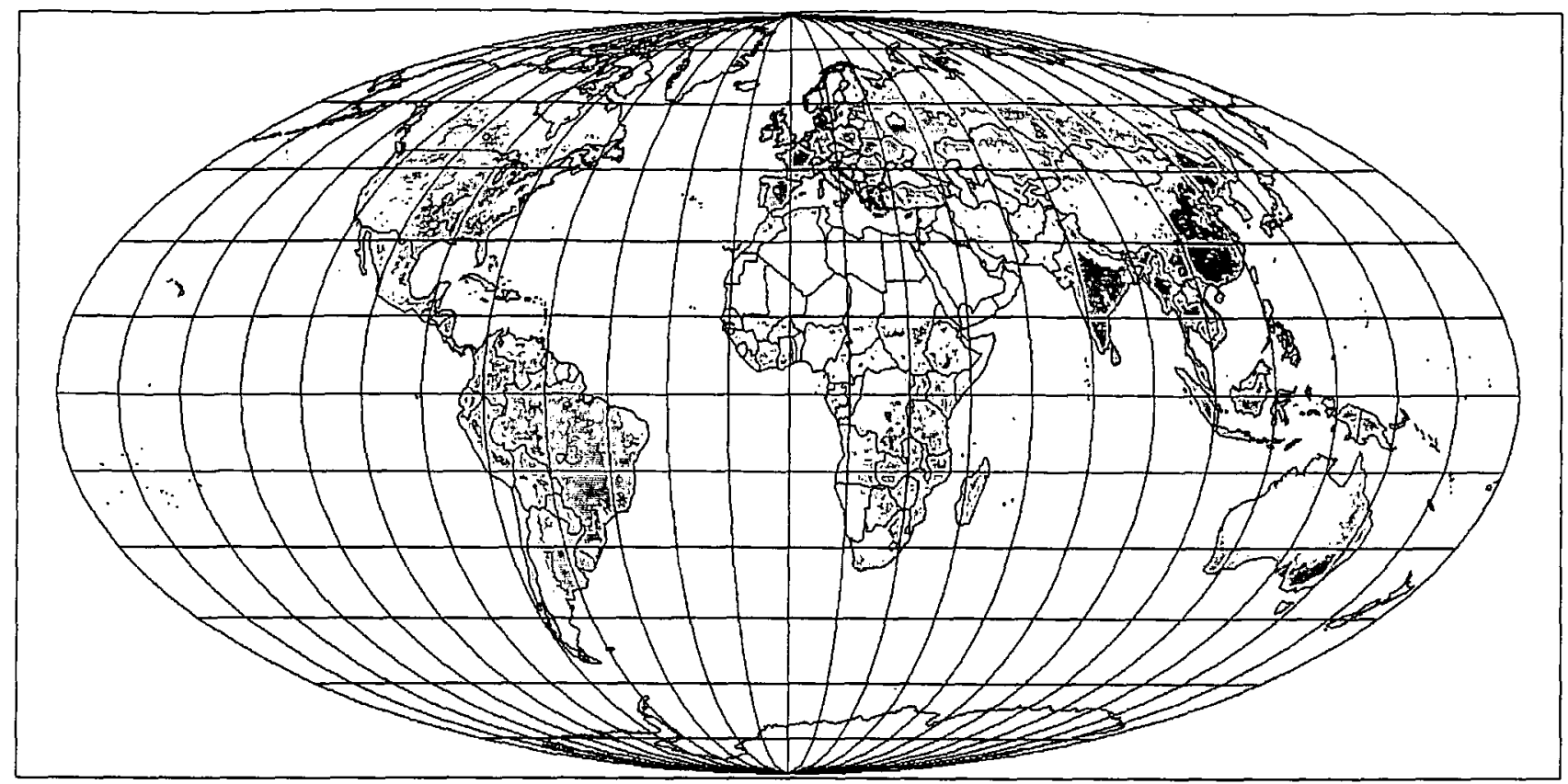

Figure 38. Local surplus of vegetable food supply over demand on an area basis, valid for both decentralised and centralised 2050 scenario. (annual average supply minus demand in $\mathrm{W} / \mathrm{m}^{2}$ is shown if positive; scale given in Figure $4 \mathrm{e}$ ).

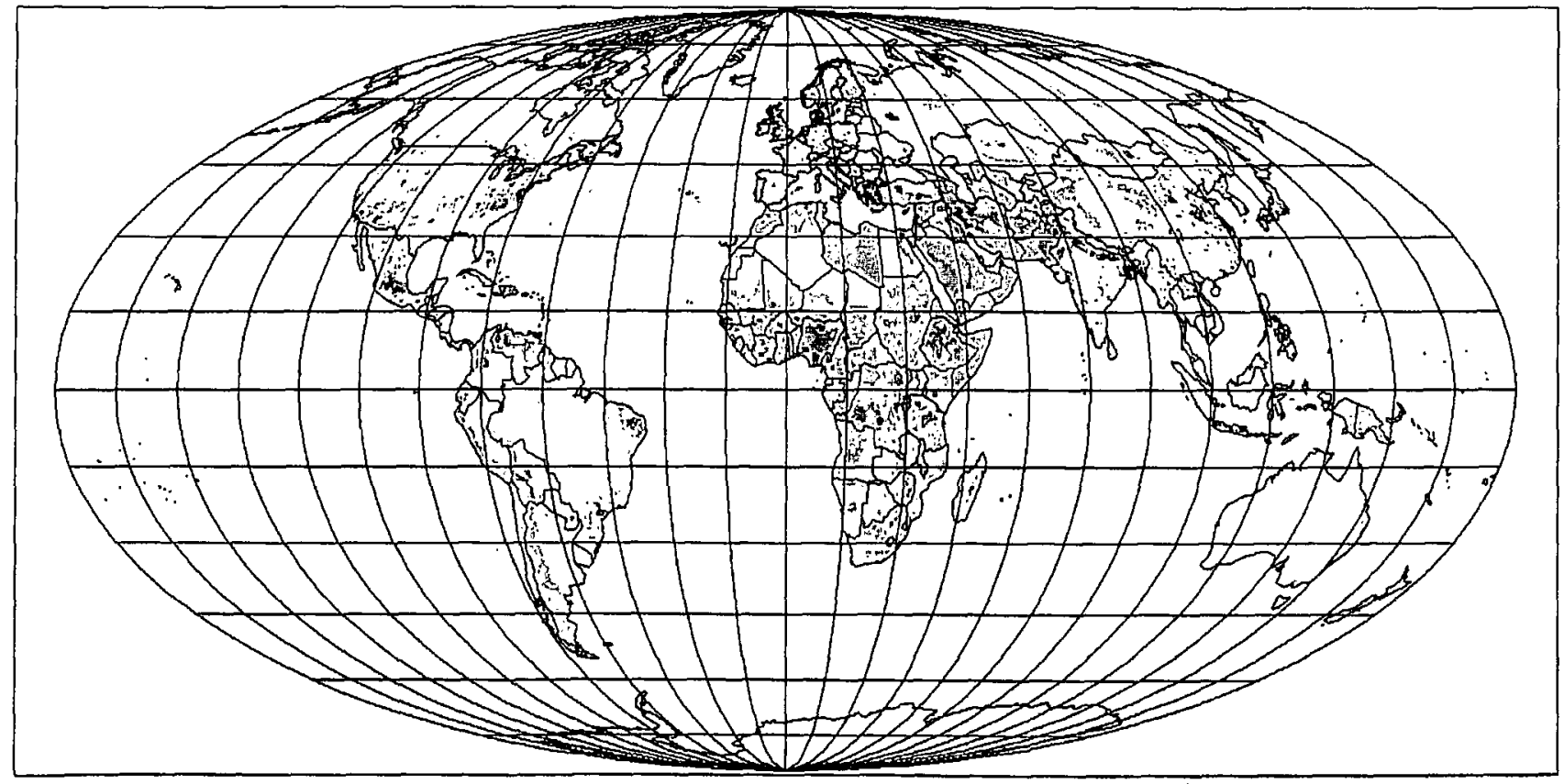

Figure 39a. Local deficit of vegetable food supply relative to demand on an area basis, valid for both decentralised and centralised 2050 scenario. (annual average demand minus supply in $\mathrm{W} / \mathrm{m}^{2}$ is shown if positive; scale given in Figure $39 \mathrm{~b}$ ). 


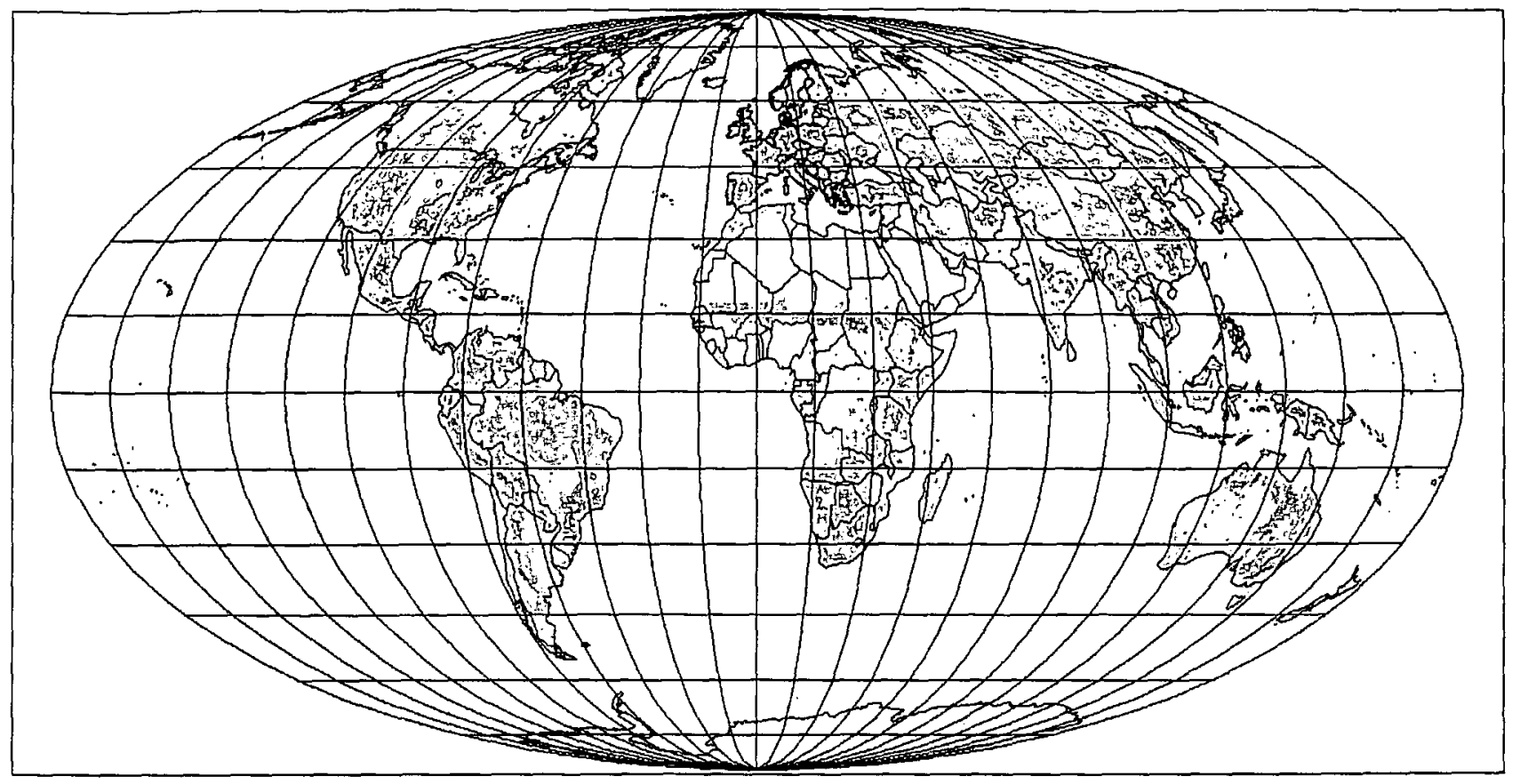

Figure 40. Local surplus of animal-based food supply over demand on an area basis, valid for both decentralised and centralised 2050 scenario. (annual average supply minus demand in $\mathrm{W} / \mathrm{m}^{2}$ is shown if positive; scale given in Figure $4 \mathrm{e}$ ).

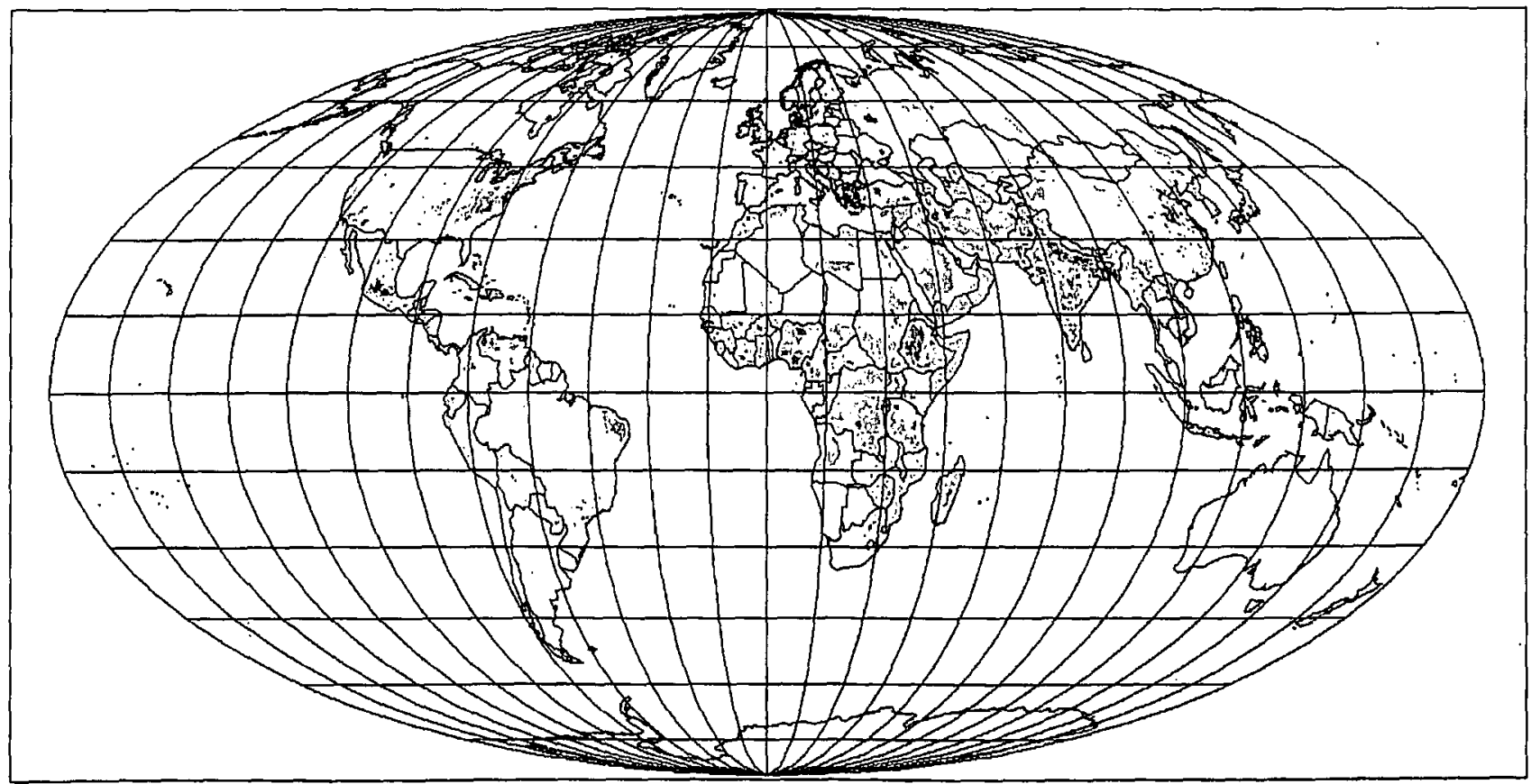

Figure 41. Local deficit of animal-based food supply relative to demand on an area basis, valid for both decentralised and centralised 2050 scenario. (annual average demand minus supply in $\mathrm{W} / \mathrm{m}^{2}$ is shown if positive; scale given in Figure $39 \mathrm{~b}$ ). 


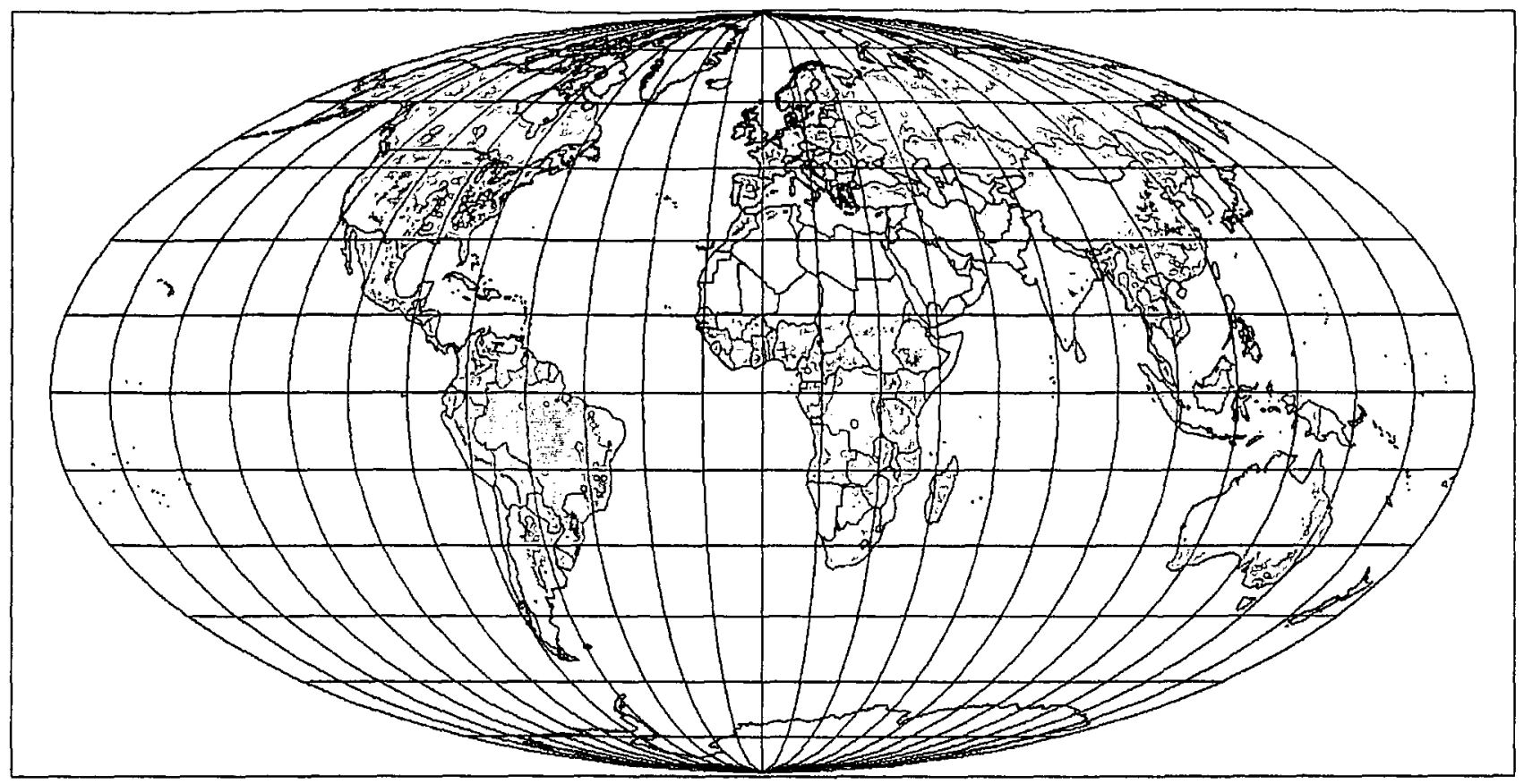

Figure 42. Local surplus of biofuel supplies (such as methanol) over demand for transportation fuels on an area basis, according to the decentralised 2050 scenario. (annual average supply minus demand in $\mathrm{W} / \mathrm{m}^{2}$ is shown if positive; scale given in Figure $4 \mathrm{e}$ ).

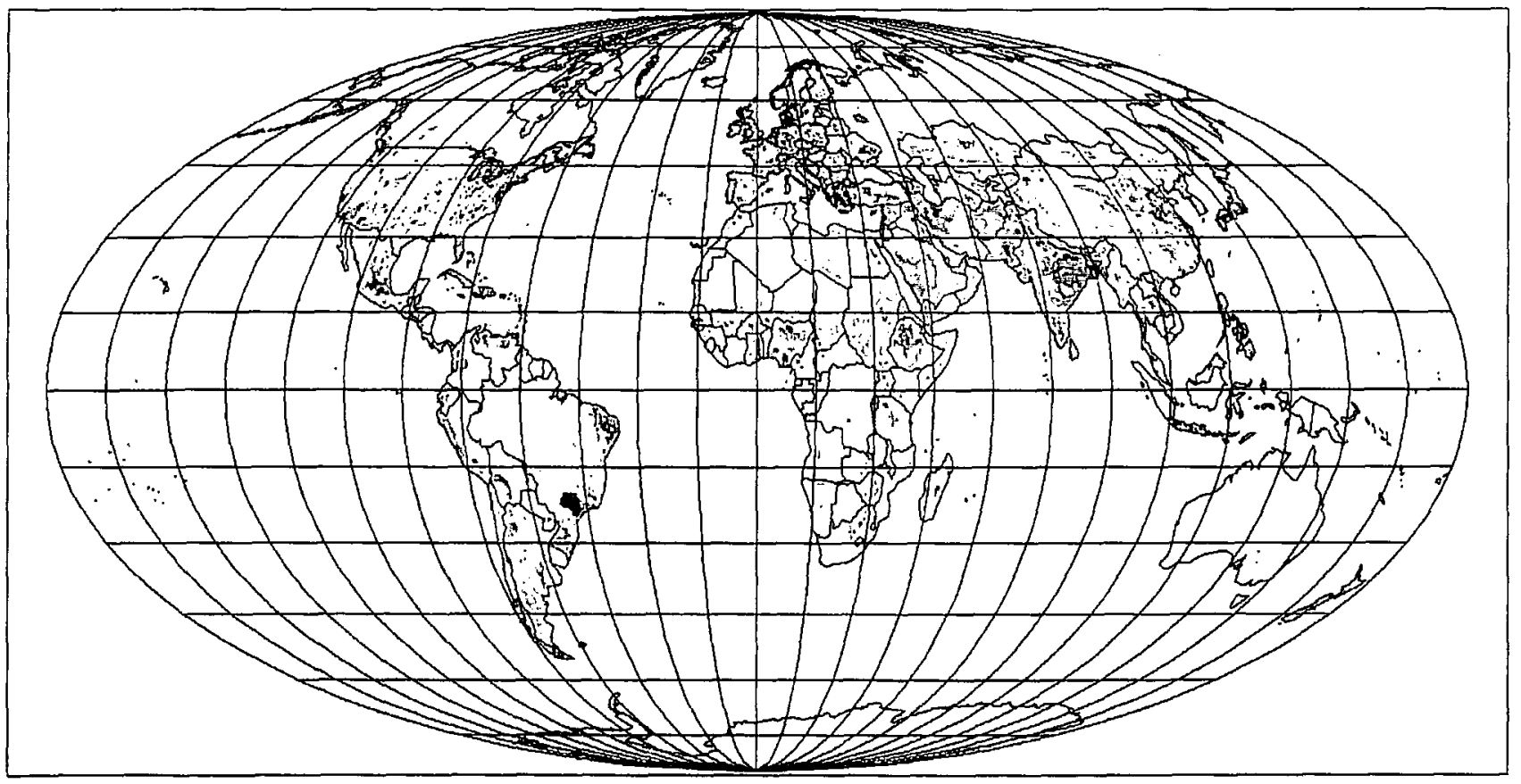

Figure 43. Local deficit of biofuel supplies (such as methanol) relative to demand for transportation fuels on an area basis, according to the decentralised 2050 scenario. (annual average demand minus supply in $\mathrm{W} / \mathrm{m}^{2}$ is shown if positive; scale given in Figure $39 \mathrm{~b}$ ). 


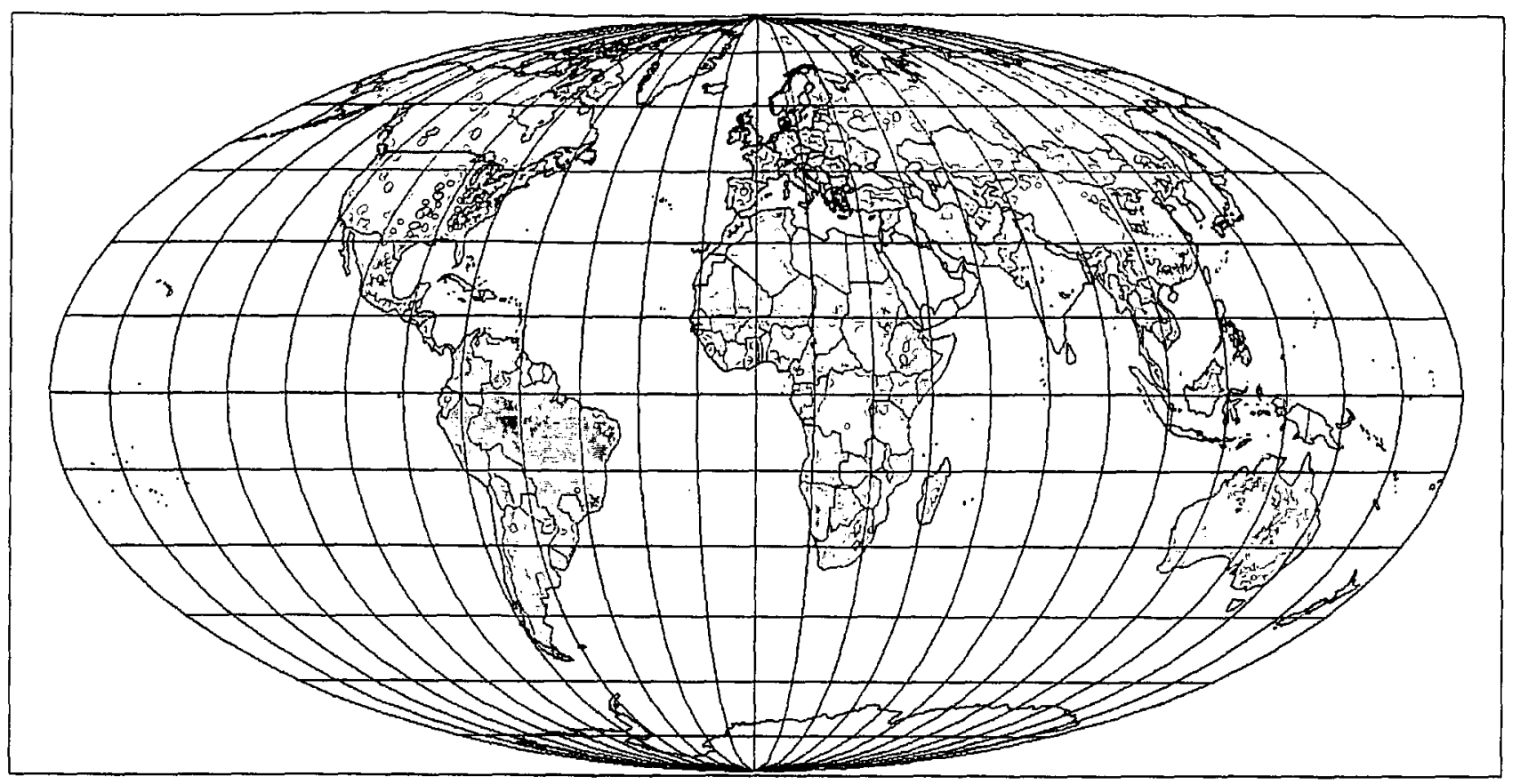

Figure 52. Annual average local surplus of supplies of electricity and biofuels (such as biogas or hydrogen) over demand (all demand except food and transportation) on an area basis, according to the decentralised 2050 scenario. (average supply minus demand in $\mathrm{W} / \mathrm{m}^{2}$ is shown if positive; scale given in Figure 4e).

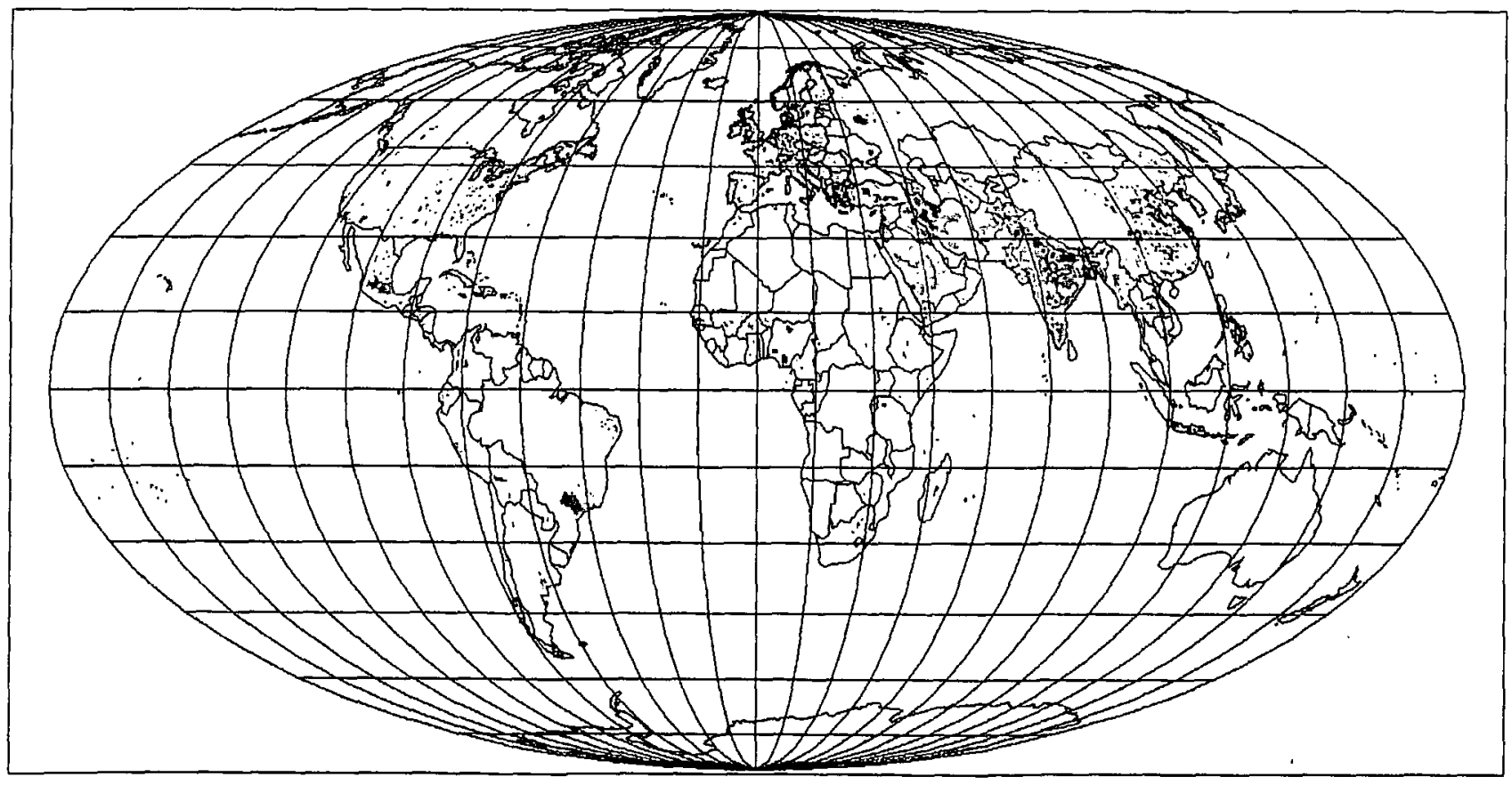

Figure 53. Annual average local deficit of the supplies of electricity and biofuels (such as biogas or hydrogen) relative to demand (all demand except food and transportation) on an area basis, according to the decentralised 2050 scenario. (average demand minus supply in $\mathrm{W} / \mathrm{m}^{2}$ is shown if positive; scale given in Figure 39b). 


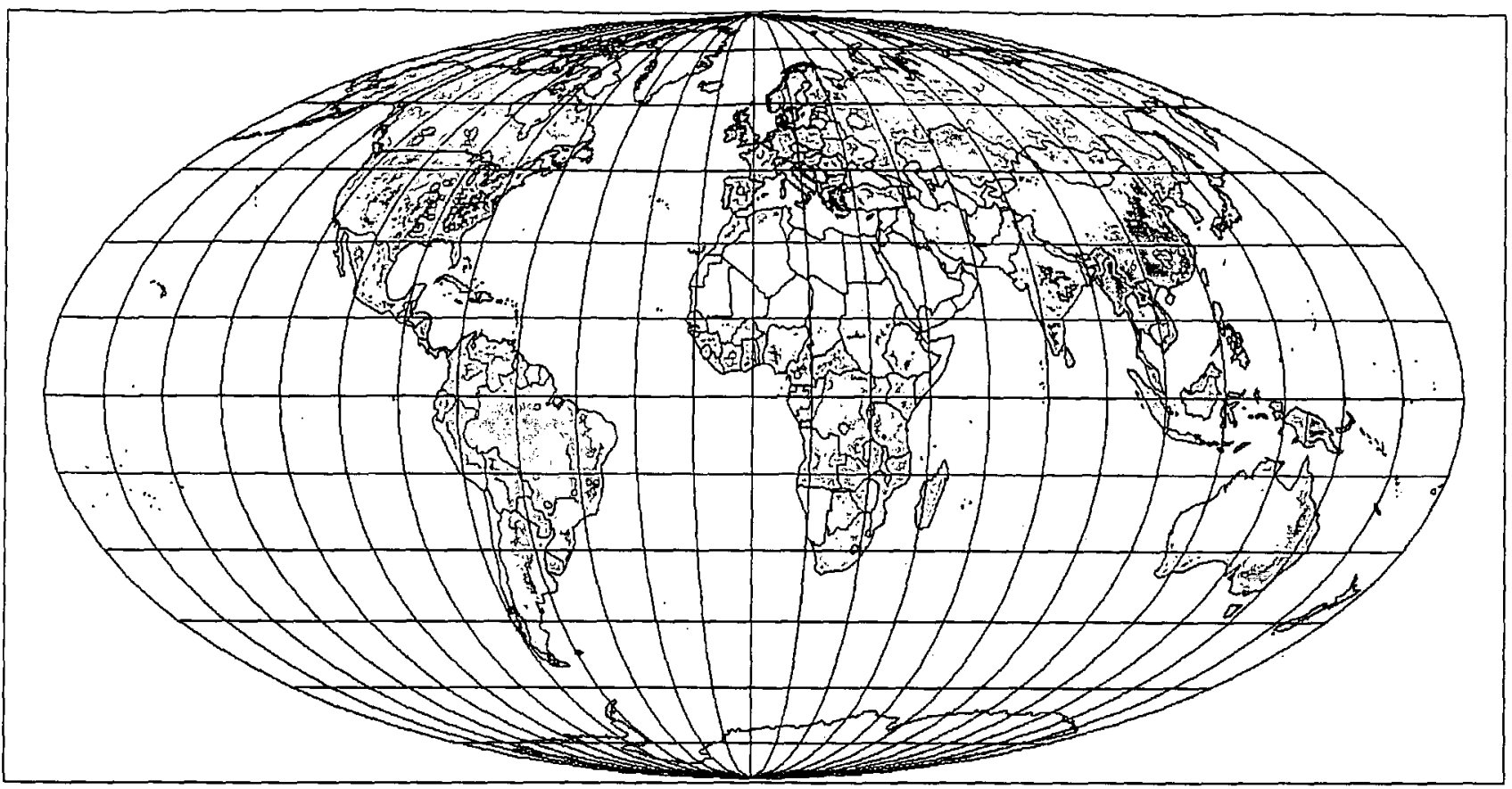

Figure 62. Local surplus of biofuel supplies (such as methanol) over demand for transportation fuels on an area basis, according to the centralised 2050 scenario. (annual average supply minus demand in $\mathrm{W} / \mathrm{m}^{2}$ is shown if positive; scale given in Figure 4e).

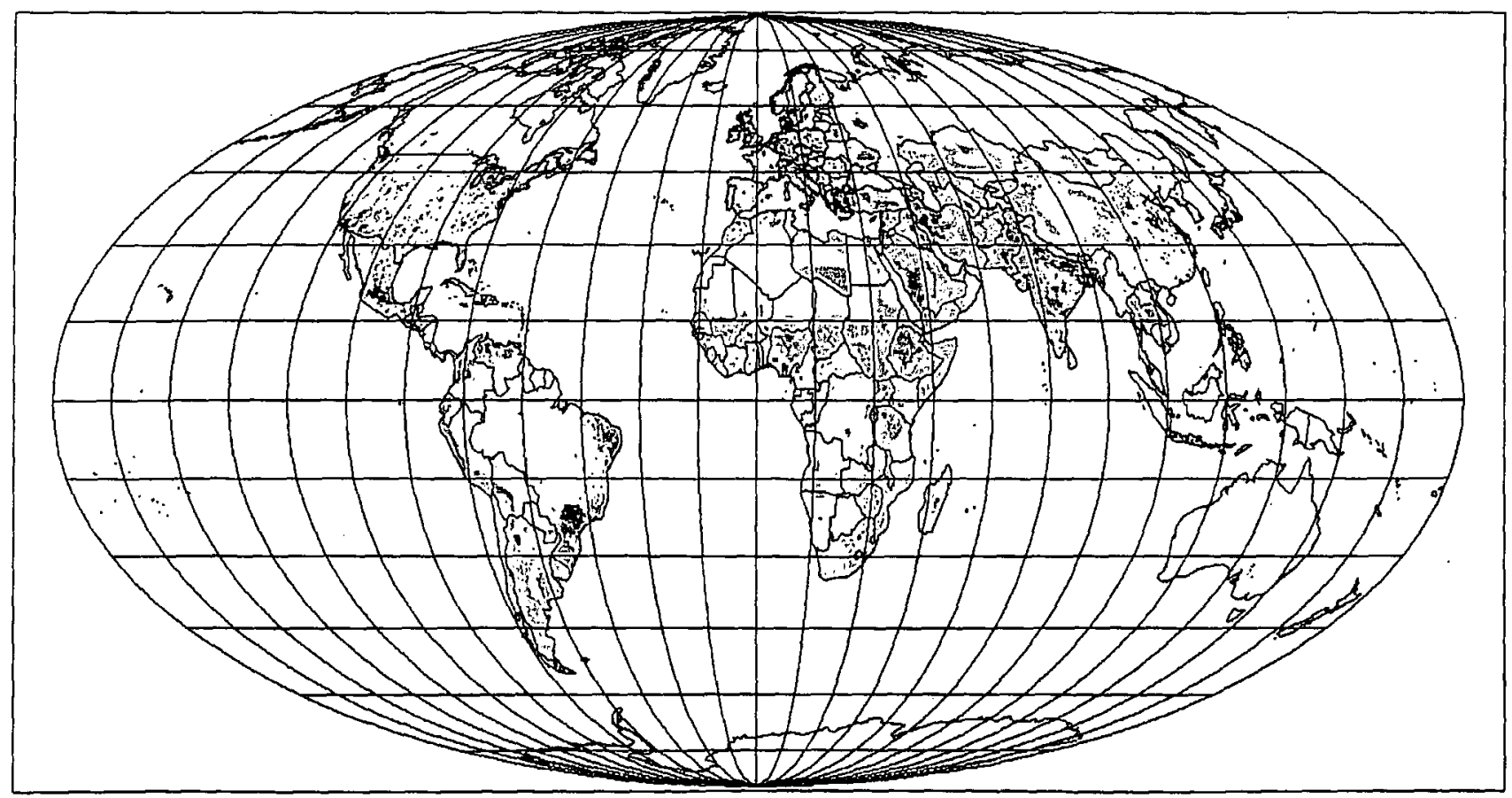

Figure 63. Local deficit of biofuel supplies (such as methanol) relative to demand for transportation fuels on an area basis, according to the centralised 2050 scenario. (annual average demand minus supply in $\mathrm{W} / \mathrm{m}^{2}$ is shown if positive; scale given in Figure $39 \mathrm{~b}$ ). 


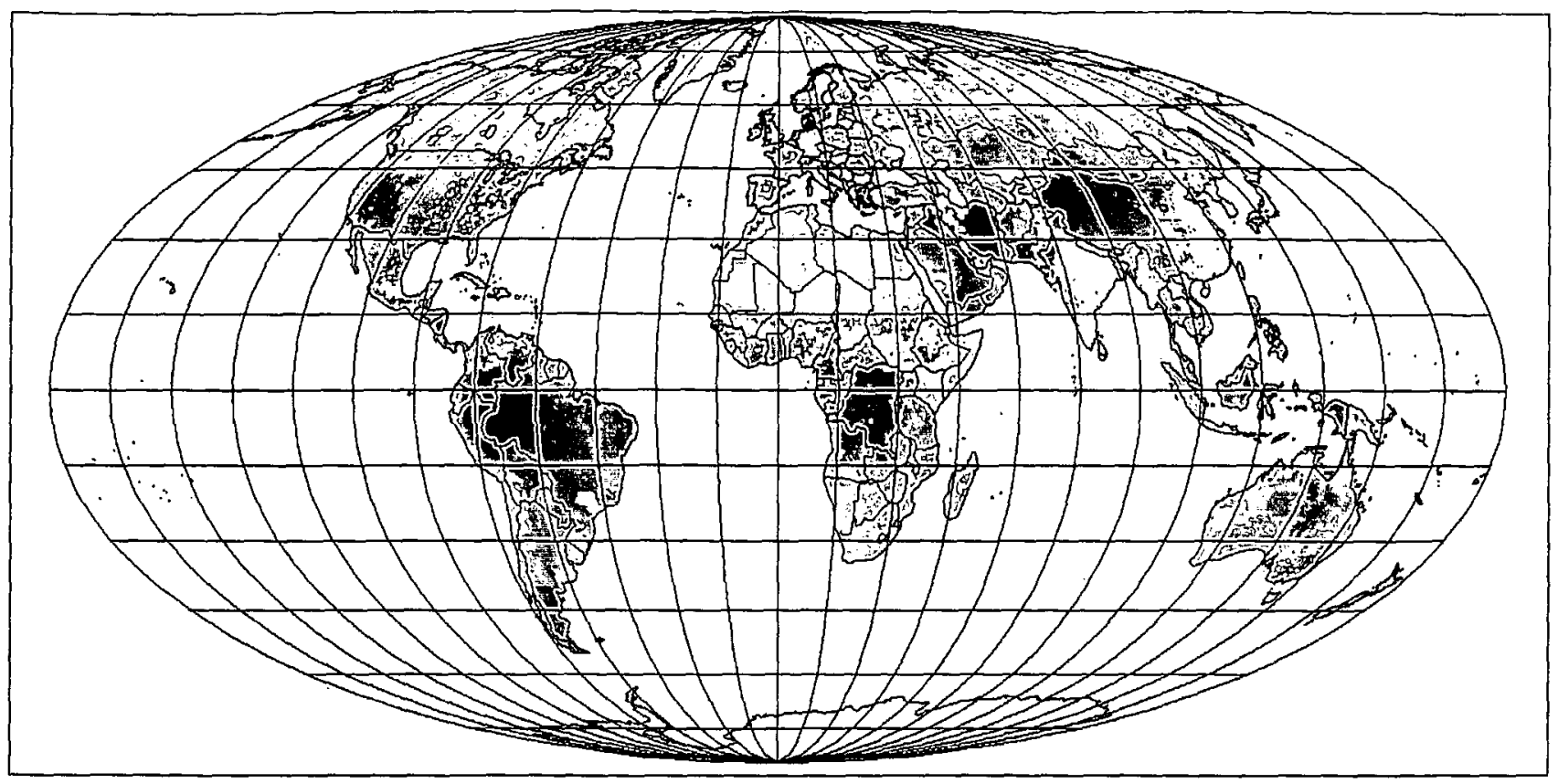

Figure 72. Annual average local surplus of supplies of electricity and biofuels (such as biogas or hydrogen) over demand (all demand except food and transportation) on an area basis, according to the centralised 2050 scenario. (average supply minus demand in $\mathrm{W} / \mathrm{m}^{2}$ is shown if positive; scale given in Figure 4e).

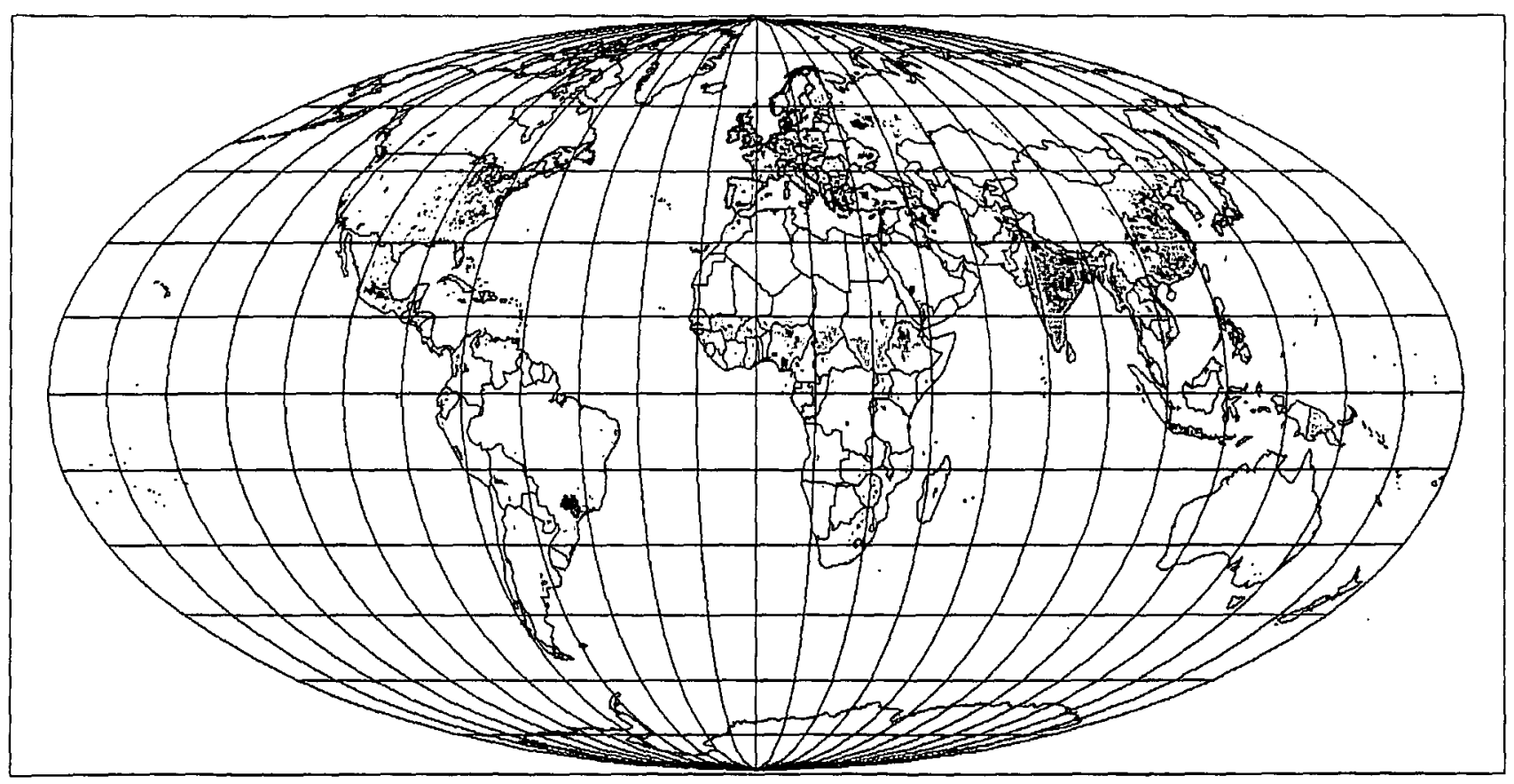

Figure 73. Annual average local deficit of the supplies of electricity and biofuels (such as biogas or hydrogen) relative to demand (all demand except food and transportation) on an area basis, according to the centralised 2050 scenario. (average demand minus supply in $\mathrm{W} / \mathrm{m}^{2}$ is shown if positive; scale given in Figure 39b). 
$227 / 92$ "Computersimulering og fysik" af: Per M.Hansen, Steffen Holm, Petel Maibom, Mads K. Dall Petersen, Pernille Postgaard, Thomas B.Schrøder, Ivar P. Zeck

Vejleder: Peder Voetmann Christiansen

Liste over tidligere udkomne tekster tilsendes gerne. Henvendelse herom kan ske til IMFUFA's sekretariat tif. 46742263
$228 / 92$ "Teknologi og historie" Fire artikler af:

Mogens Niss, ¿ens Høyrup, ib Thiersen, Hans Hedal

229/92 "Nasser af information uden becydning" En diskussion af informationsteorien $i$ T'or Nøiretianders' "Mæik Verden" og en skitse til et alternativ basserei på andenordens kybernetik og semioiik. af: Søren Brier

$230 / 92$ "Vinklens treàeling - et klassisk problem"

et matemacisk projekt af

Karen Birkelund, Bjøin Christensen vejleder: ت̈ohnny Ottesen

$231 \mathrm{~A} / 92$ "Elektcondiffusion i silicium -- en matematisk model"

af: Jesper Voetmann, Karen Birkelund Nette Olufsen, Ole Møller Nielsen

Vejledere: Johnny Ottesen, H.B.Hansen

231B/92 "Elektrondiffusion i silicium - en matematisk model" Kildetekstei

af : vesper Voetmann, Karen Birkelunà; Mette Olufsen, Ule Mojller Nielsen

Vejleciere: Johnny Otiesen, H.B.Hansen

232/92 "Undersøgelse om den. simultane opdagelse af energiens bevarelse.og isaicales on de af Mayer, colding, Joule og Helmholtz udførte arbejder"

af: L.Arleth, G.I.Dybkjær, M.T.Østergảrd Vejleder: Dorthe Posselt

$233 / 92$ "The effect of age-dependent host mortality on the dynamics of an endemic disease and Instability in an SIR-model with agedependent susceptibility

by: Viggo Andreasen

234/92 "THE FUNCTIONAL DETERMINANT OF A FOUR-DTMENSIONAL BOUNDARY VALUE PROBLEM"

by: Thomas P. Branson and Peter B. Gilkey

235/92 OVERFLADESTRUKTUR OG POREUDVIKLING AF KOKS

- Modul 3 fysik projekt -

af: Thomas Jessen CIRCULATION OF SELECTED EMISSIONS FROM ENERGY CONVERSION"

by: Bent Sørensen 
$236 a / 93$ INTRODUKTION TIL KVANTE

HALL EFFEKTEN

af: Ania Boisen, Peter Boggild

Vejleder: Peder Voetmann Christiansen Erland Brun Hansen

236b/93 STRØMSSAMMENBRUD AF KVANTE

HALL EFFEKTEN

af: Anja Boisen, Peter Boggild

Vejleder: Peder Voetmann Christiansen Erland Brun Hänsen

237/93 The Wedderburn principal theorem and Shukla cohomology

af : Lars Kadison

$238 / 93$ SEMIOTIK OG SYSTEMEGENSKABER ( 2

Vektorbånd og tensorer

af: Peder Voetmann Christiansen

239/93 Valgsystemer - Modelbygning og analyse

Matematik 2. modul

af: Charlotte Gjerrild, Jane Hansen,

Maria Hermannsson, Allan Jorgensen,

Ragna Clauson-Kaas, Poul Lützen

Vejleder: Mogens Niss

240/93 Patologiske eksempler

Om sære matematiske fisks betydning for den matematiske udvikling

af: Claus Dræby, Jørn Skov Hansen, Runa

Ulsoe Johansen, Peter Meibom, Johannes

Kristoffer Nielsen

Vejleder: Mogens Niss

241/93 FOTOVOLTAISK STATUSNOTAT 1

af: Bent Sørensen

$242 / 93$ Brovedligeholdelse - bevar mig vel

Analyse af vejdirektoratets model for optimering af broreparationer

af: Linda Kyndlev, Kare Fundal, Kamma

Tulinius, Ivar zeck

Vejleder: Jesper Larsen

243/93 TANKEEKSPERTMENTER I.FYSIKKEN

E't l.modul fysikprojekt

af: Karen Birkelund, stine Sofia Korremann

Vejleder: Dorthe Posselt

244/93 RADONTRANSFORMATIONEN Of dens anvendelse

i CT-scanning

Projektrapport

af: Trine Andreasen, Tine Guldager Christiansen,

Nina Skov Hansen og Christine Iversen

Vejledere: Gestur olafsson og Jesper Larsen

$245 a+b$

193 Time-of-Flight målinger på krystallinske

halvledere

Specialerapport

af : Linda Szkotak Jensen og Lise Odgaard Gade

Vejledere: Petr Viscor og Niels Boye Olsen

$246 / 93$ HVERDAGSVIDEN OG MATEMATIK

- LEREPROCESSER I SKOLEN

af: Lena Ijindenskov, Statens Humanistiske

Forskningsråd, RUC, IMFUFA
$247 / 93$ UNIVERSAL LOW TEMPERATURE AC CONDUCTIVITY OF MACROSCOPICALLY DISORDERED NON-METALS

by: Jeppe C. Dyre

$248 / 93$ DIRAC OPERATORS AND MANIFOLDS WITH BOUNDARY

by: B. Booss-Bavnbek, K.P.Wojciechowski

249/93 Perspectives on Teichmüller and the Jahresbericht Addendum to Schappacher Scholz, et al.

by: B. Booss-Bavnbek

With comments by W.Abikoff, L.Ahlfors, J.Cerf, P.J.Davis, W.Fuchs, F.P.Gardiner, J.Jost, J. -P.Kahane, R.Lohan, L.Lorch, I.Radkau and T.Söderqvist

250/93 EULER OG BOLZANO - MATEMATISK ANALYSE SET I ET VTDENSKABSTEORETISK PERSPEKTTV

Projektrapport af: Anja Juul, Lone Michelsen, Tomas Hojgåd Iensen

Vejieder: Stig Andur Pedersen

251|93 Genotypic Proportions in Bybrid Zones

by: Freddy Bugge Christiansen, Viggo Andreasen and Ebbe Thue Poulsen

\section{2|93 MODELLERING AF TILFALDIGE EANOMENER}

Projektrapport af: Birthe Friis, Lisbeth Helmgaard, Kristina Charlotte Jakobsen, Marina Mosbok Johannessen, Lotte Ludvigsen, Mette Hass Nielsen

253/93 Kuglepakning

Teori og model

af: Lise Arleth, Kåre Fundal, Nils Kruse

Vejleder: Mogens Wiss

254/93 Regressionsanalyse

Materiale til et statistikkursus

af: Jorgen Larsen

255/93 TID \& BETINGET UAFHKNGIGHED

af: Peter Harremoës

256/93 Determination of the Frequency Dependent Bulk Modulue of Liquids Using a Pieaoelectric Spherical shell (Preprint)

by: T. Christensen and N.B.Olsen

257/93 Modellering af dispersion i piezoelektriske keranikkex

af: Pexnille Postgaard, Jannik Rasmussen, Chriatina Specht, Mikko Dstergård

Vejleder: Tage Chriatensen

258/93 Supplerende kursusmateriale til "Lineare strukturer fra algebra og anatyse"

af: Mogens Brun Beefelt

259/93 STUDTES OF AC HOPPING CONDUCTTON AT LOW TEMPERATURES

by: Jeppe C. Dyre

260/93 PARTITIONED MANTFOLDS AND INVARIANTS IN DIMENSTONS $2,3, A N D 4$

by: B. Booss-Bambek, K.P.Wojciechowski 
261,93 OPGAVESAMLING

Bredde-kursus i Fysik

Eksamensopgaver fra 1976-93

262/93 Separability and the Jones

Polynomial

by: Lars Kadison

263/93 Supplerende kursusmateriale til

"Linexre strukturer fra algebra

oq analyse" II

af: Mogens Brun Heefelt

$264 / 93$ FOTOVOLTAISK STATUSNOTAT 2

af: Bent Sørensen

\section{5/94 SPHERICAL FUNCTIONS ON ORDERED} SYMMETRIC" SPACES

To sigurdur Helgason on his sixtyfifth birthday

by: Jacques Faraut, Joachim Hilgert and Gestur olafsson

266/94 Kommensurabilitets-oscillationer i laterale supergitre.

Fysikspeciale af: Anja Boisen, Peter Bøggild, Karen Birkelund

Vejledere: Rafael Taboryski, Poul Erik Lindelof, Peder Voetmann Christiansen

267/94 Kom til kort med matematik på Eksperimentarium - Et forslag til en opstilling

af: Charlotte Gjerrild, Jane Hansen Vejleder: Bernhelm Booss-Bavnbek

268/94 Life is like a: sewer :. .

Et projekt om modellering af aorta via en model for strøming i kloakrør

af: Anders Marcussen, Anne C. Nilsson, Lone Michelsen, Per M. Hansen

Vejleder: Jesper Larsen

269/94 Dimensionsanalyse en introduktion metaprojekt, fysik

af: Tine Guldager Christiansen, Ken Andersen, Nikolaj Hermann, Jannik Rasmussen

Vejleder: Jens Højgaard Jensen

2\%0/94 THE IMAGE OF THE ENVELOPING ALGEBRA AND IRREDUCIBILITY OF INDUCED REPRESENTATIONS OF EXPONENTIAL LIE GROUPS by: Jacob Jacobsen

$2 \ddot{7} 1 / 94$ Matematikken i Fysikken. Opdaget eller opfundet NAT-BAS-projekt vejleder: Jens Højgaard Jensen
272/94 Tradition og fornyelse

Det praktiske elevarbejde $i$ gymnasiets fysikundervisning, 1907-1988

af: Kristian Hoppe og Jeppe Guldager

Vejledning: Karin Beyer og Nils Hybel

273/94 Model for kort- og mellemdistanceløb

Verifikation af model

af: Lise Fabricius Christensen, Helle Pilemann, Bettina Sorensen

Vejleder: Mette Olufsen

274/94 MODEL 10 - en matematisk model af intravenøse anæstetikas farmakokinetik

3. modul matematik, forår 1994

af: Trine Andreasen, Bjorn Christensen, Christine Green, Anja Skjoldborg Hansen. Lisbeth Helmgaard

Vejledere: Viggo Andreasen \& Jesper Larsen

275/94 Perspectives on Teichmiller and the Jahresbericht 2nd Edition

by: Bernhelm Booss-Bavnbek

276/94 Dispersionsmodellering

Projektrapport 1. modul

af: Gitte Andersen, Rehannah Borup, Lisbeth Friis, Per Gregersen, Kristina Vejrø

Vejleder: Bernhelm Booss-Bavnbek

277/94 PROJEKTARBEJDSPEDAGOGIK - Om tre tolkninger af problemorienteret projektarbejde

af: Claus Flensted Behrens, Frederik Voetmann Christiansen, Jørn Skov Hansen, Thomas Thingstrup

Vejleder: Jens Højgaard Jensen

278/94 The Models Underlying the Anaesthesia Simulator Sophus

by: Mette Olufsen(Math-Tech), Finn Nielsen (RISø National Laboratory), Per Føge Jensen (Herlev University Hospital), Stig Andur Pedersen (Roskilde University)

279/94 Description of a method of measuring the shear modulus of supercooled liquids and a comparison of their thermal and mechanical response functions.

af: Tage Christensen

280/94 A Course in Projective Geometry by Lars Kadison and Matthias T. Kromann

281/94 Modellering af Det Cädiovaskulare System med Neural Pulskontrol

Projektrapport udarbejdet af:

Stefan Frello, Runa Ulsbe Johansen, Michael Poul Curt Hansen, Klaus Dahl Jensen Vejleder: Viggo Andreasen

282/94 Parallelle algoritmer

af: Erwin Dan Nielsen, Jan Danielsen, Niels Bo Johansen 
283/94 Grænser for tilfældighed

(en kaotisk talgenerator)

af: Erwin Dan Nielsen og Niels Bo Johansen

284/94 Det er ikke til at se det, hvis man ikke lige ve' det!

Gymnasiematematikkens begrundelsesproblem

En specialerapport af Peter Hauge Jensen

og Linda kyndlev

Ve.ileder: Mogens Niss

285/94 Slow coevolution of a viral pathogen and its diploid host

by: Viggo Andreasen and

Freddy B. Christiansen

286/94 The energy master equation: A low-temperature approximation to Bässler's random walk model by: Jeppe C. Dyre

287/94 A Statistical Mechanical Approximation for the Calculation of Time Auto-Correlation Functions by: Jeppe C. Dyre

288/95 PROGRESS IN WIND ENERGY UTILIZATIION by: Bent Sorensen

289/95 Universal Time-Dependence of the Mean-Square Displacement in Extremely Rugged Energy Landscapes with Equal Minima

by: Jeppe C. Dyre and Jacob Jacobsen

290/95 Modellering af uregelmæssige bolger

Et 3.modul matematik projekt

af: Anders Marcussen, Anne Charlotte Nilsson, Lone Michelsen, Per Markegaard Hansen

Vejleder: Jesper Larsen

291/95 1st Annual Report from the project LIFE-CYCLE ANALYSIS OF THE TOTAL DANISH ENERGY SYSTEM

an example of using methods developed for the OECD/IEA and the US/EU fuel cycle externality study

by: Bent Sørensen

292/95 Fotovoltaisk Statusnotat 3

af: Bent Sørensen

293/95 Geometridiskussionen - hvor blev den af?

af: Lotte Ludvigsen \& Jens Frandsen

Vejledur: Anders Madsen

294/95 Universets udvidelse -

et metaprojekt

Af: Jesper Duelund og Birthe Friis

Vejleder: Ib Lundgaard Rasmussen

295/95 A Review of Mathematical Modeling of the Controled Cardiovascular System

By: Johnny T. Ottesen
296/95 RETIKULER den klassiske mekanik

af: Peder Voetmann Christiansen

$297 / 95$ A fluid-dynamical model of the aorta with bifurcations

by: Mette Olufsen and Johnny Ottesen

298/95 Mordet på Schrödingers kat - et metaprojekt om to fortolkninger af kvantemekanikken

af: Maria Hermannsson, Sebastian Horst, Christina Specht

Vejledere: Jeppe Dyre og Peder Voetmann Christiansen

299/95 ADAM under figenbladet - et kig på en samfunds-

videnskabelig matematisk model

Et matematisk modelprojekt

af: Claus Dræby, Michael Hansen, Tomas Højgård Jensen Vejleder: Jorgen Larsen

300/95 Scenarios for Greenhouse Warming Mitigation

by: Bent Sarensen

$301 / 95$ TOK Modellering af træers vakst under påvirkning af ozon

af: Glenn Møller-Holst, Marina Johannessen, Birthe Nielsen og Bettina Sorensen

Vejleder: Jesper Larsen

302/95 KOMPRESSORER - Analyse af en matematisk model for aksialkompressorer

Projektrapport sf: Stine Bøggild, Jakob Hilmer, Pernille Postgaard

Vejleder: Viggo Andreasen

303/95 Masterlignings-modeller af Glasovergangen Termisk-Mekanisk Relaksation Specialerapport udarbejdet af:

Johannes K. Nielsen, Klaus Dahl Jensen

Vejledere: Jeppe C. Dyre, Jørgen Larsen

304a/95 STATISTIKNOTER Simple binomialfordelingsmodeller af: Jorgen Larsen

304b/95 STATISTIKNOTER Simple normalfordelingsmodelier af: Jorgen Larsen

304c/95 STATISTIKNOTER Simple Poissonfordelingsmodeller af: Jorgen Larsen

304d/95 STATISTIKNOTER Simple multinomialfordelingsmodelier af: Jørgen Larsen

304e/95 STATISTIKNOTER Mindre matematisk-statistisk opslagsværk indeholdende b1.a. ordforklaringer, resumeer og tabeller af: Jorgen Larsen 
305/95 The Maslov Index:

A Functional Analytical Definition

And The Spectral Flow Formula

By: B. Booss-Bavnbek, K. Furutani

306/95 Goals of mathematics teaching

Preprint of a chapter for the forthcomming International Handbook of Mathematics Education (Alan J.Bishop, ed)

By: Mogens Niss

307/95 Habit Formation and the Thirdness of Signs Presented at the semiotic symposium The Emergence of Codes and Intensions as a Basis of Sign Processes

By: Peder Voetmann Christiansen

308/95 Metaforer i Fysikken

af: Marianne Wilcken Bjerregaard, Frederik Voetmann Christiansen,

Jorn. Skov Hansen, Klaus Dahl Jensen

Ole Schmidt

Vejledere: Peder Voetmann Christiansen og Petr Viscor

309/95 Tiden og Tanken

En undersøgelse of begrebsverdenen Matematik udfort ved hjalp af en analogi med tid

af: Anita Stark og Randi Petersen

Vejleder: Bernhelm Booss-Bavnbek

310/96 Kursusmateriale til "Lineare strukturer fra algebra og analyse" (E1)

af: Mogens Brun Heefelt

311/96 2nd Annual Report from the project LIFE-CYCLE ANALYSIS OF THE TOTAL DANISH ENERGY SYSTEM

by: Hélène' Connor-Lajambe, Bernd Kuemmel, Stefan Krüger Nielsen, Bent Sørensen

312/96 Grassmannian and Chiral Anomaly

by: B. Booss-Bavnbek, K.P.Wojciechowski

313/96 THE IRREDUCIBILITY OF CHANCE AND THE OPENNESS OF THE FUTURE The Logical Function of Idealism in Peirce's Philosophy of Nature By: Helmut Pape, University of Hannover

314/96 Feedback Regulation of Mammalian Cardiovascular System

By: Johnny T. Ottesen

315/96 "Rejsen til tidens indre" - Udarbejdelse af

$a+b$ et manuskript til en fjernsynsudsendelse

+ manuskript

af: Gunhild Hune og Karina Goyle

Vejledere: Peder Voetmann Christiansen og Bruno Ingemann
316/96 Plasmaoscillation i natriumklynger

Specialerapport af: Peter Meibom, Mikko Ustergård Vejledere: Jeppe Dyre \& Jørn Borggreen

317/96 Poincaré og symplektiske algoritmer

af: Ulla Rasmussen

Vejleder: Anders Madsen

318/96 Modelling the Respiratory System

by: Tine Guldager Christiansen, Claus Dræby

Supervisors: Viggo Andreasen, Michael Danielsen

319/96 Externality Estimation of Greenhouse Warming Impacts

by: Bent Sørensen

320/96 Grassmannian and Boundary Contribution to the -Determinant

by: K.P.Wojciechowski et al.

321/96 Modelkompetencer - udvikling og afprovning af et begrebsapparat

Specialerapport af: Nina Skov Hansen, Christine Iversen, Kristin Troels-Smith Vejleder: Morten Blomhøj

322/96 OPGAVESAMLING

Bredde-Kursus i Fysik 1976 - 1996

323/96 Structure and Dynamics of Symmetric Diblock Copolymers

PhD Thesis

by: Christine Maria Papadakis

324/96 Non-linearity of Baroreceptor Nerves by: Johnny T. Ottesen

325/96 Retorik eller realitet ? Anvendelser af matematik i det danske Gymnasiums matematikundervisning $i$ perioden $1903-88$

Specialerapport af Helle Pilemann Vejleder: Mogens Niss

326/96 Bevisteori

Eksemplificeret ved Gentzens bevis for konsistensen af teorien om de naturlige tal af: Gitte Andersen, Lise Mariane Jeppesen, Klaus Frovin Jorgensen, Ivar Peter Zeck Vejledere: Bernhelm Booss-Bavnbek og Stig Andur Pedersen

327/96 NON-LINEAR MODELLING OF INTEGRATED ENERGY SUPPLY AND DEMAND MATCHING SYSTEMS

by: Bent Serensen

328/96 Calculating Fuel Transport Emissions by: Bernd Kuemme1 
329/96 The dynamics of cocirculating influenza strains conferring partial cross-immunity and

A model of influenza A drift evolution

by: Viggo Andreasen, Juan Lin and Simon Levin

330/96 LONG-TERM INTEGRATION OF PHOTOVOLTAICS INTO THE GLOBAL ENERGY SYSTEM

by: Bent Sørensen

$331 / 96$ Viskøse fingre

Specialerapport af:

Vibeke Orlien og Christina Specht

Vejledere: Jacob M. Jacobsen og Jesper Larsen

332/97 ANOMAL SWELLING AF LIPIDE DOBBELTLAG

Specialerapport af:

Stine Sofia Korremann

Vejleder: Dorthe Posselt

333/97 Biodiversity Matters

an extension of methods found in the literature on monetisation of biodiversity

by: Bernd Kuemmel

334/97 LIFE-CYCLE ANALYSIS OF THE TOTAL DANISH ENERGY SYSTEM

by: Bernd Kuemmel and Bent Sorensen

335/97 Dynamics of Amorphous Solids and Viscous Liquids by: Jeppe C. Dyre

336/97 PROBLEM-ORIENTATED GROUP PROJECT WORK AT ROSKILDE UNIVERSITY

by: Kathrine Legge

337/97 Verdensbankens globale befolkningsprognose

- et projekt om matematisk modellering

af: Jørn Chr. Bendtsen, Kurt Jensen, Per Pauli Petersen

Vejleder: Jørgen Larsen

338/97 Kvantisering af nanolederes elektriske

ledningsevne

Forste modul fysikprojekt

af: Søren Dam, Esben Danielsen, Martin Niss, Esben Friis Pedersen, Frederik Resen Steenstrup

Vejleder: Tage Christensen
339/97 Defining Discipline

by: Wolfgang Coy

340/97 Prime ends revisited - a geometric point of view -

by: Carsten Lunde Petersen

341/97 Two chapters on the teaching, learning and aasessment of geometry

by Mogens Niss

342/97 'LONG-TERM SCENARIOS FOR GLOBAL ENERGY DEMAND AND SUPPLY

A global clean fossil scenario discussion paper prepared by Bernd Kuemmel

Project leader: Bent Sorensen

343/97 IMPORT/EKSPORT-POLITIK SOM REDSKAB TIL OPTIMERET UDNYTTELSE AF EL PRODUCERET PÅ VE-ANLEG

af: Peter Meibom, Torben Svendsen, Bent Sørensen

344/97 Puzzles and Siegel disks

by Carsten Lunde Petersen

345/98 Modeling the Arterial System with Reference to an Anestesia Simulator

Ph.D. Thesis

by: Mette Sofie Olufsen

346/98 Klyngedannelse $i$ en hulkatode-forstroningsproces

af: Sebastian Horst

Vejledere: Jørn Borggren, NBI, Niels Boye Olsen

$347 / 98$ Verificering af Matematiske Modeller

- en analyse af Den Danske Eulerske Model

af: Jonas Blomqvist, Tom Pedersen, Karen Timmermann, Lisbet Øhlenschlager

Vejleder: Bernhelm Booss-Bavnbek

348/98 Case study of the environmental permission procedure and the environmental impact assessment for power plants in Denmark

by: Stefan Krüger Nielsen

Project leader: Bent Sørensen

349/98 Tre rapporter fra FAGMAT - et projekt om tal og faglig matematik $i$ arbejdsmarkedsuddannelserne af: Lena Lindenskov og Tine Wedege

360/98 OPGAVESAMLING - Bredde-Kursus i Fysik 1976 - 1998 Erstatter teksterne $3 / 78,261 / 93$ og 322/96

351/98 Aspects of the Nature and State of Research in Mathematics Education

by: Mogens Niss 


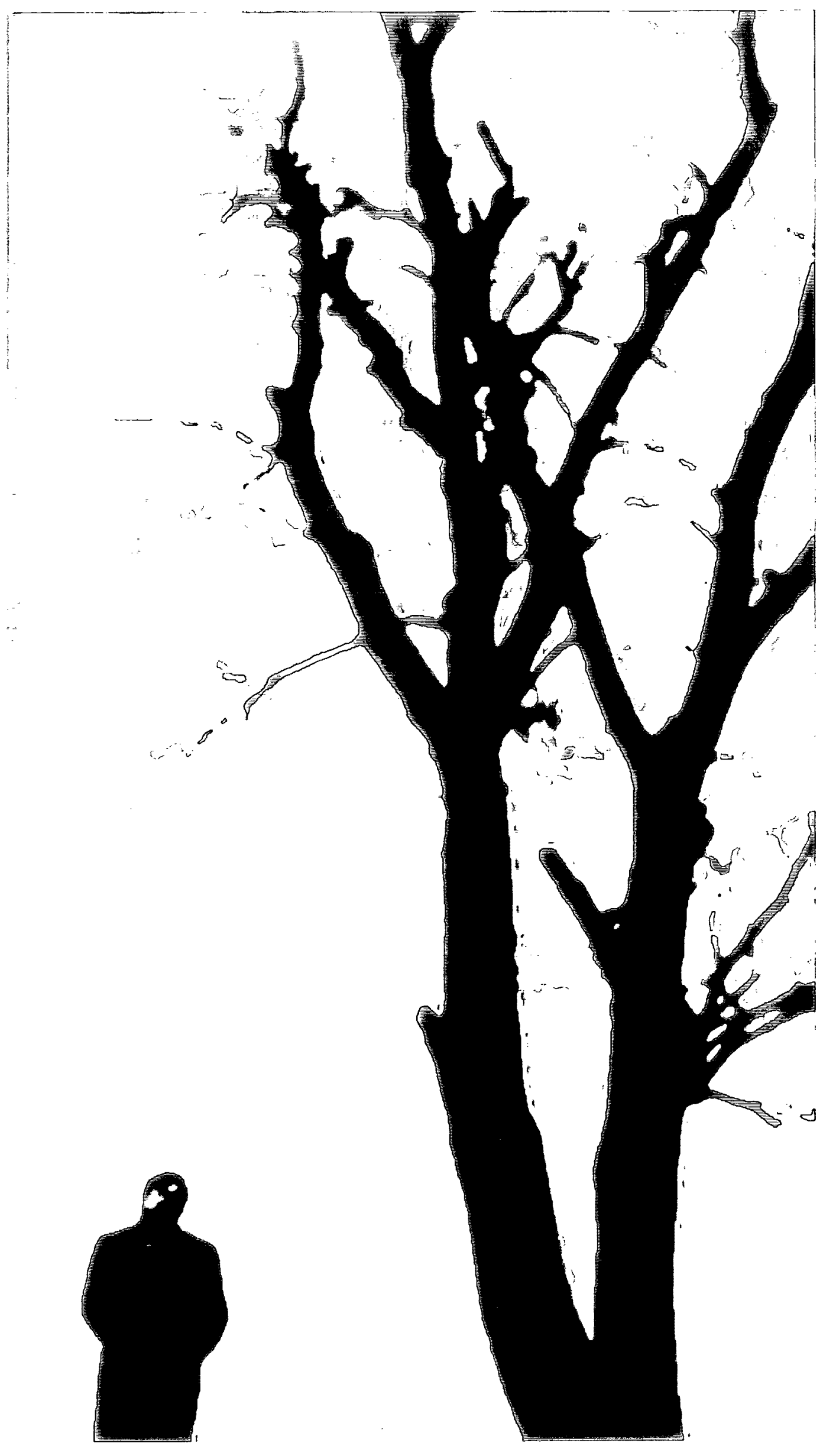

